
$+1$
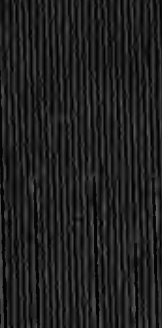

(I) 
Aco

$-1$ 


\section{Digitized by the Internet Archive in 2008 with funding from Microsoft Corporation}



SOUTH CAROLINA

AS A ROYAL PROVINCE

$$
\text { I } 7 \text { 19-1 } 77^{6}
$$


The $x$ ix 
HUS

566479

\section{SOUTH CAROLINA}

AS A

R OYAL PROVI NCE

$1719-1776$

BY

W. ROY SMITH, Ph. D.

ASSOCIATE IN HISTORY IN BRYN MAWR COLLEGE

Nelw York:

THE MACMILLAN COMPANY LONDON : MACMILLAN \& CO., LTD. 1903

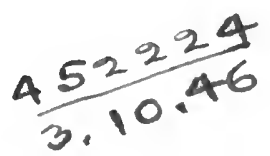


Copyright, 1903,

BY THE MACMILLAN COMPANY.

Set up and published September, 1903.

PRESS OF

IHE NEW ERA PRINTING COMPANY,

LANCASTER, PA. 


\section{PREFACE}

Students of the French Revolution have long since come to realize that they must begin their researches at least as early as the reign of Louis XIV., if they would understand the real significance of that great movement. The same is true of our American Revolution. The historian who takes the Peace of 1763 as the starting point will find himself involved in difficulties that are insurmountable. Without assuming, as Chalmers does, that the colonists were all along consciously striving for independence, I think that we may safely affirm that the real history of the revolt dates from the founding of the first English settlement in Virginia. From that time until the final appeal to arms in 1775 there was in every colony an unceasing struggle between the representatives of the people and the representatives of prerogative interests. The general character of the conflict was the same in all, a reproduction on a small scale of the constitutional history of the mother country. The object of this monograph is to trace the progress of the struggle in South Carolina, with the hope that it may throw some light upon the history of the American Revolution.

The author desires to express his obligations to those who have aided him in the preparation of this work. Though but few can be mentioned by name, the services of all are held in grateful remembrance. $\mathrm{He}$ 
feels especially indebted to Professor Herbert L. Osgood, of Columbia University, who suggested the subject and lessened the labors of composition by his encouragement and advice.

Acknowledgment should also be made to the Honorable M. R. Cooper, formerly Secretary of State of South Carolina, and to Mr. Jesse T. Gantt and Mr. David Means of his office for courtesies extended while searching the colonial archives; to Mr. Yates Snowden and Mr. August Kohn, of the Charleston Neus and Courier, for assistance in securing access to the various collections in Charleston; to Mrs. M. B. Jackson, of Austin, Texas, for aid in revising and correcting the manuscript; and to my friend, Dr. Chauncey B. Tinker, of Yale University, for reading the proof.

BRy MAWr, PA.,

W. Roy Smith.

May, 1903. 


\section{TABLE OF CONTENTS}

iNtrodetcion. The Proprietary Period (1670-1719)

PAGE.

Introduction.

Unity of colonial history $\ldots \ldots \ldots \ldots \ldots \ldots \ldots \ldots \ldots \ldots \ldots$ I

Plan of book......................

The Proprietary Period.

Establishment and early development of the colony....... 3

Three phases of proprietary rule............... 7

Struggle between settlers and proprietors $(1670-1700) \ldots \quad 7$

Struggle between Churchmen and Dissenters (1700-1706). S

Renewed struggle between settlers and proprietors (1706-

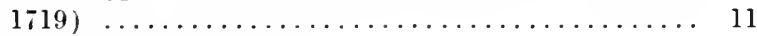

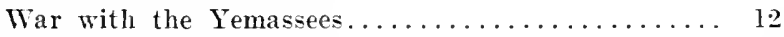

Repeal of election laws................ 12

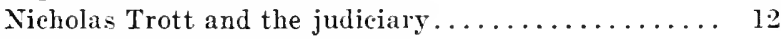

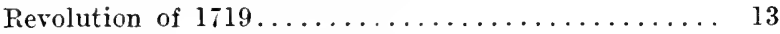

Appointment of public officials............ 15

Power of initiating legislation............. 20

Summary ....................

\section{SECTION I}

\section{LAND SYSTEM}

Chapter I. Origix axd Denelopyent of the System Derixg the Proprietary Period

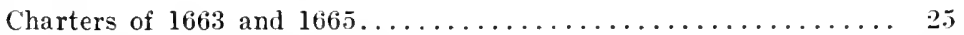

Fundamental Constitutions...................... 26

Commissions and instructions................... $\mathbf{2 6}$

Disputes between the settlers and the proprietors.......... 25

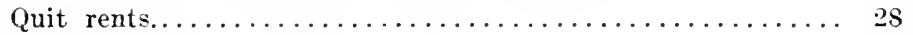

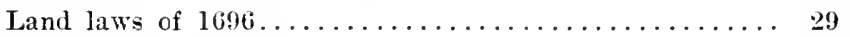

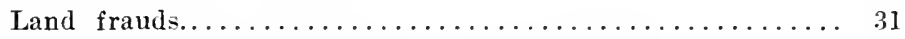

Purchase of proprietary interests by the crown $(1729) \ldots \ldots \ldots \ldots$;2 


\section{CHAPTER II. LAND FraUds}

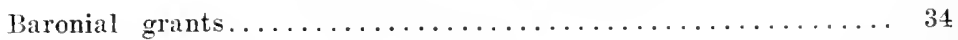

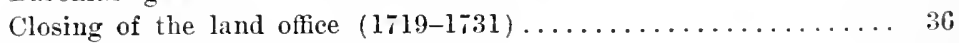

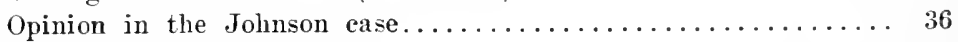

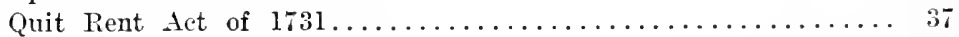

Opportunity for fraud................... 37

Arguments of Surveyor-General St. John and Attorney-General

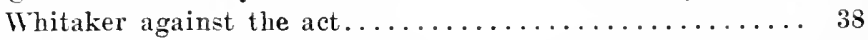

Revenge of the land speculators................ 41

Dispute over Judge Wright's salary. An independent judiciary 44

Success of the speculators.................... 48

Results of massing land in large tracts................ 48

Commissioner MeCulloh's attempts to put an end to frands...... 48

Opposition of governor and council.............. 49

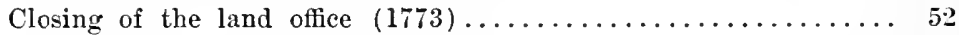

New system of granting land $(1774) \ldots \ldots \ldots \ldots \ldots \ldots \ldots \ldots \ldots \ldots \ldots$

\section{CHAPTER III. QUiT REXTS}

Collections during the proprietary period............. 54

Proprietary claims purchased by crown $(1729) \ldots \ldots \ldots \ldots \ldots \ldots 5$

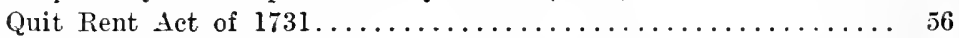

McCulloh's attempts to secure a better rent roll.......... 5 j

Proposals of 1741. Presentment of the Charleston grand jury. 58

Dispute with Secretary Hammerton............... 60

Dispute over the election of a public treasurer......... 61

Rent Roll Bill of $1744 \ldots \ldots \ldots \ldots \ldots \ldots \ldots \ldots \ldots \ldots \ldots$.

Judge Whitaker's arguments in favor of it........ 65

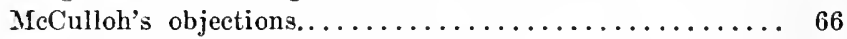

Probable fate of the bill in England............. 67

Summary. Reasons for failure of the crown............ 69

\section{SECTION II \\ GOVERNMENT \\ CHAPTER I. THE Executive}

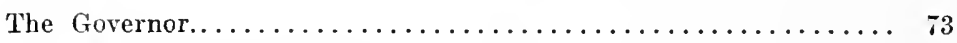

Method of appointment.................. 73

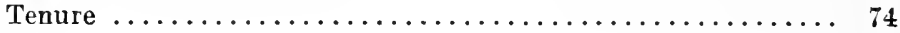


Order of succession....................... 74

Remuneration. Salary, fees, fines, and forfeitures........ 74

Commissions and instructions. The written constitution of the

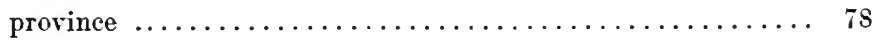

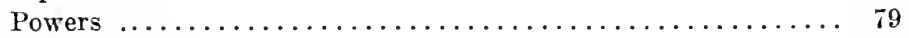

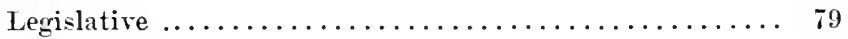

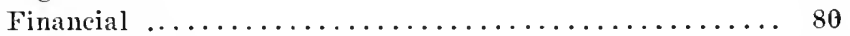

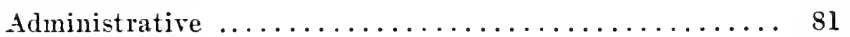

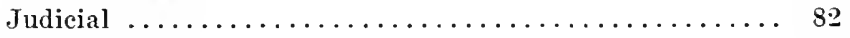

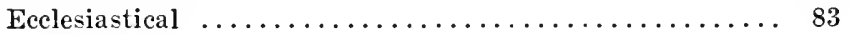

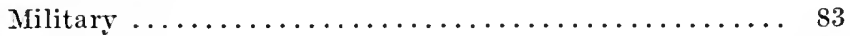

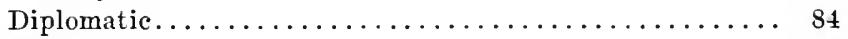

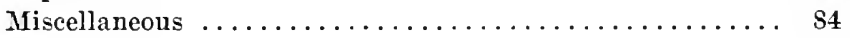

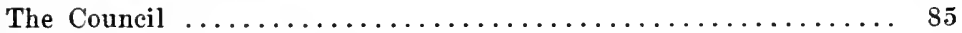

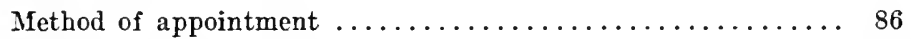

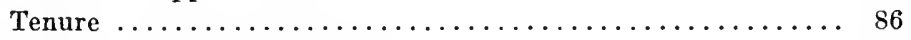

Powers. Threefold character.................. 87

Other Executive Officials $\ldots \ldots \ldots \ldots \ldots \ldots \ldots \ldots \ldots \ldots \ldots \ldots \ldots$

\section{CHAPTER II. The Legislature}

Development during the proprietary period............ 89

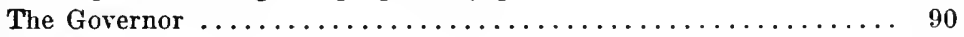

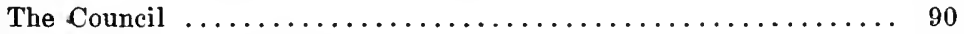

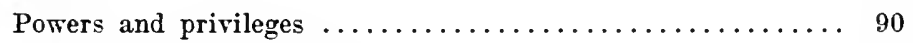

Exclusion of the governor $\ldots \ldots \ldots \ldots \ldots \ldots \ldots \ldots \ldots \ldots \ldots . \ldots 2$

Confusion of functions $\ldots \ldots \ldots \ldots \ldots \ldots \ldots \ldots \ldots \ldots \ldots .94$

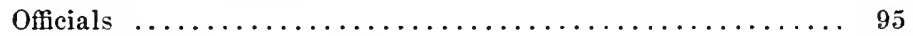

The Commons House of Assembly................. 95

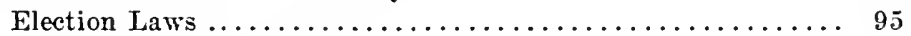

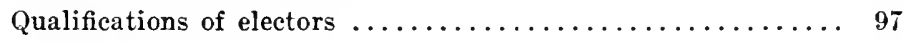

Qualifications of members $\ldots \ldots \ldots \ldots \ldots \ldots \ldots \ldots \ldots . \ldots \ldots$

Apportionment of representatives ............... 100

Procedure in elections $\ldots \ldots \ldots \ldots \ldots \ldots \ldots \ldots \ldots \ldots \ldots \ldots$

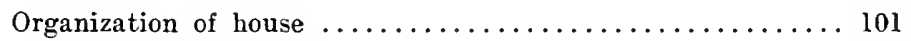

Powers and privilege $\ldots \ldots \ldots \ldots \ldots \ldots \ldots \ldots \ldots \ldots \ldots \ldots \ldots$

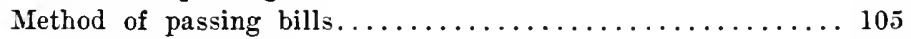

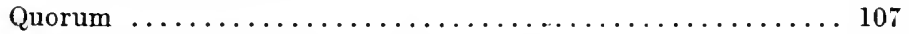

Duration of assemblies ...................... 108

Officers. Disputes over election of speaker and clerk...... 110 


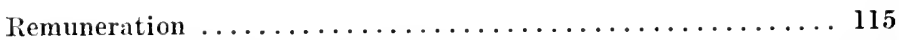

Attempted changes in the election law .............. 115

\section{CHAPTER III. THE JUdiciary}

Judicial Powers of the Governor and Council............ 118

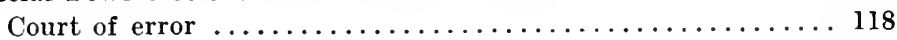

Ordinary court $\ldots \ldots \ldots \ldots \ldots \ldots \ldots \ldots \ldots \ldots \ldots \ldots \ldots$

Court of chancery $\ldots \ldots \ldots \ldots \ldots \ldots \ldots \ldots \ldots \ldots \ldots \ldots \ldots$

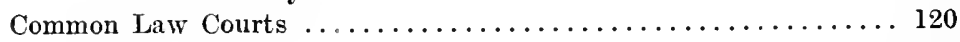

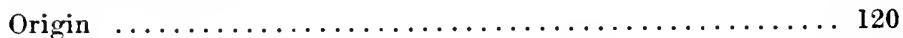

Common law adopted into the province $(1712) \ldots \ldots \ldots \ldots 121$

Chief Justice Nicholas Trott.................. 122

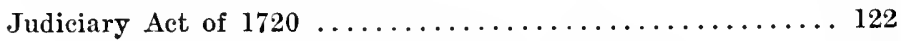

Encroachment on judicial powers of the governor...... 122

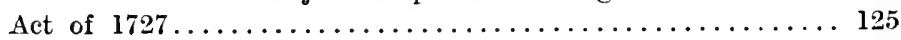

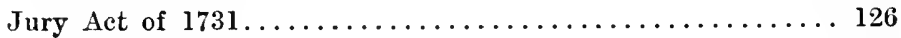

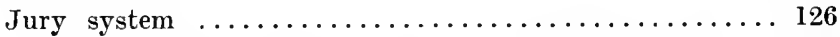

Court of general sessions placed on a statutory basis.... 127

Prisoners allowed council................. 127

Acts of 1732 and 1734. Repealed in England.......... 128

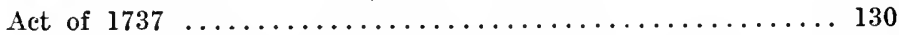

Court of common pleas placed on a statutory basis...... 130

Whitaker letter of February $3,1742 \ldots \ldots \ldots \ldots \ldots \ldots \ldots \ldots 131$

Power of courts to pass upon constitutionality of laws.... 132

The Circuit Court Act of $1769 \ldots \ldots \ldots \ldots \ldots \ldots \ldots \ldots \ldots \ldots \ldots \ldots \ldots \ldots$

Necessity for courts in the back country. The Regulators.... 133

Purchase of provost marshal's interests............. 134

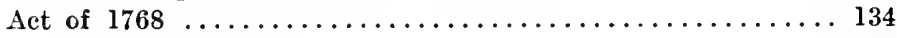

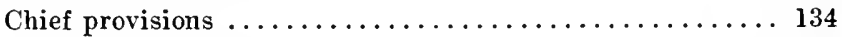

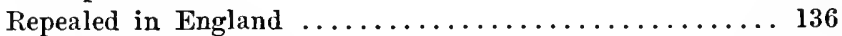

Tenure of judges $\ldots \ldots \ldots \ldots \ldots \ldots \ldots \ldots \ldots \ldots \ldots$

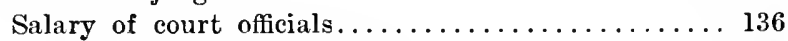

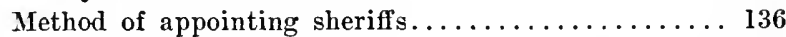

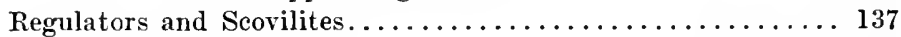

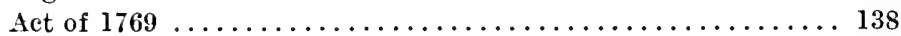

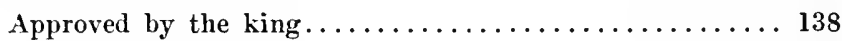

Judges appointed $\ldots \ldots \ldots \ldots \ldots \ldots \ldots \ldots \ldots \ldots \ldots \ldots \ldots 139$

Building of court houses and gaols........... 139

Law put into operation $(1772) \ldots \ldots \ldots \ldots \ldots \ldots \ldots \ldots 14$

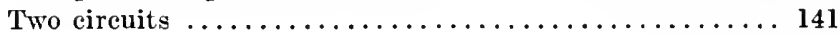




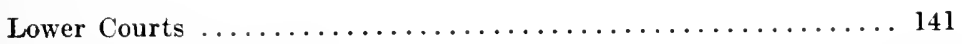

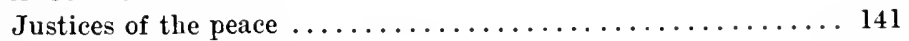

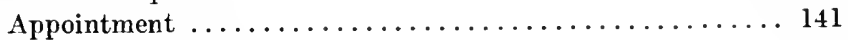

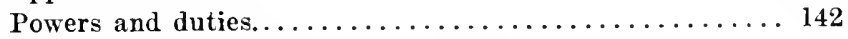

Attempt to establish "courts of conscience" (1747) ....... 142

Courts for trial of negroes.................. 143

Coroners ............................. 145

Attempt to establish county and precinct courts (1721) .... 145

The Admiralty Court ...................... 147

Difficulty in enforcing Acts of Trade and Navigation....... 147

Admiralty court established $(1697) \ldots \ldots \ldots \ldots \ldots \ldots \ldots \ldots$

Unsuccessful attempt of the British government to centralize the colonial admiralty $\ldots \ldots \ldots \ldots \ldots \ldots \ldots \ldots \ldots \ldots$

Court of vice-admiralty for all America $(1764) \ldots \ldots \ldots 149$

Four courts of vice-admiralty $(1768) \ldots \ldots \ldots \ldots \ldots \ldots, 149$

Powers and jurisdiction of the court............. 150

Piracy, treason, felony, and murder............ 150

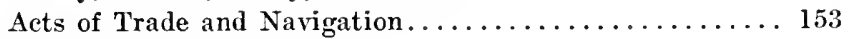

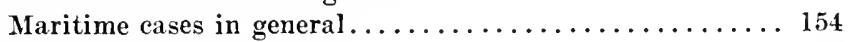

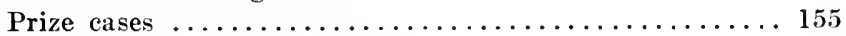

Attempt to establish a court of exchequer $\ldots \ldots \ldots \ldots \ldots \ldots \ldots \ldots 6$

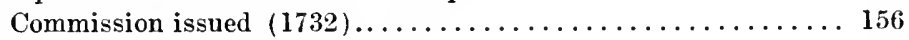

Assembly refuses to pass jury law ............... 157

CHAPTER IV. Colonial Agents

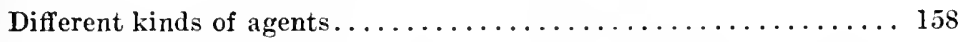

Establishment and early history of the South Carolina agency

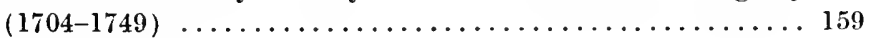

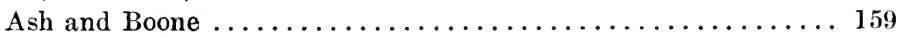

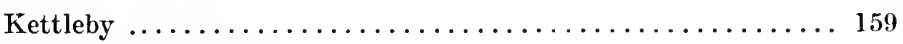

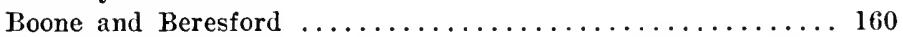

Yonge and Lloyd. Committee of correspondence. Duties of

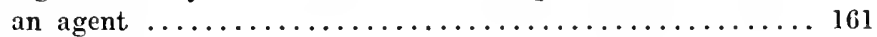

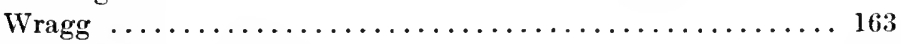

Fury. Method of election ................. 164

Assembly secures control over the agent. $(1749-1775) \ldots \ldots \ldots \ldots 164$

James Crokatt appointed . . . . . . . . . . . . . 165

Continued in office against the will of governor and council... 166

Nature of the victory $\ldots \ldots \ldots \ldots \ldots \ldots \ldots \ldots \ldots \ldots \ldots$

James Wright appointed.................. 169 
Charles Garth. Assembly controls committee of correspondence 169 Advantages of control over agencr.............. 170

\section{CHAPTER Y. Militia axd Defrise}

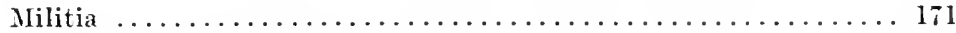

Necessity for militia organization $\ldots \ldots \ldots \ldots \ldots \ldots \ldots \ldots \ldots 17$

Militia Laws ........................ 173

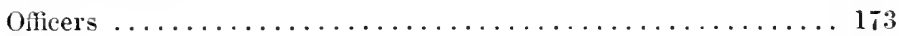

Men .................................. 175

Rewards and punishments. Pension system......... 176

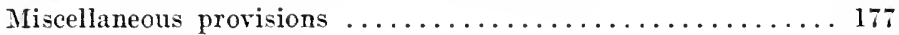

Artillery .............................

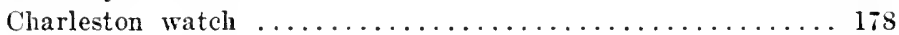

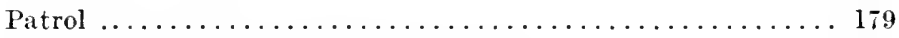

Effectiveness of the system as a whole.............. 181

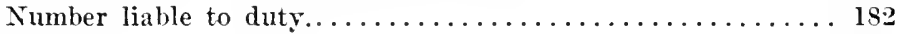

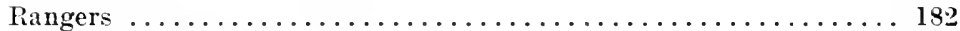

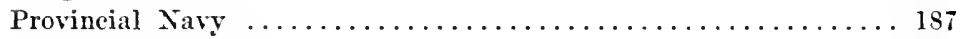

Independent Companies...................... 192

Coast Defenses. Charleston fortifications............. 196

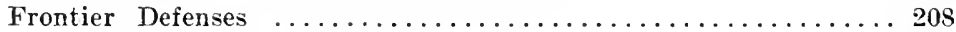

Port Royal and Fort Moore $(1716) \ldots \ldots \ldots \ldots \ldots \ldots \ldots \ldots 208$

Fort King George $(1721) \ldots \ldots \ldots \ldots \ldots \ldots \ldots \ldots \ldots \ldots . \ldots 209$

Pallachocola old Town $(1723) \ldots \ldots \ldots \ldots \ldots \ldots \ldots \ldots \ldots \ldots$

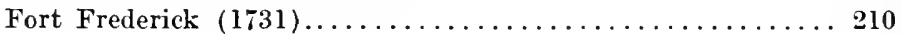

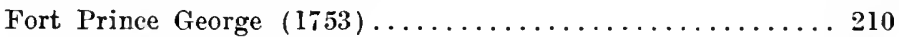

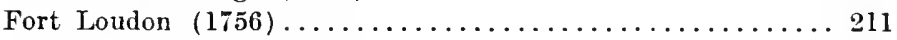

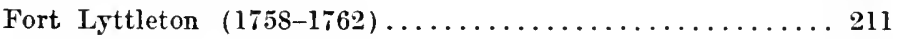

Fort Charlotte $(1765-1766) \ldots \ldots \ldots \ldots \ldots \ldots \ldots \ldots \ldots \ldots 212$

Indian Relations .............................

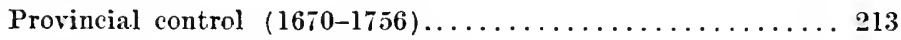

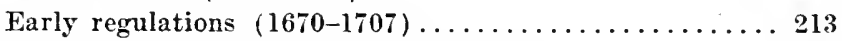

Plural commissioner system $(1707-1716) \ldots \ldots \ldots \ldots \ldots 214$

Public corporation system $(1716-1721) \ldots \ldots \ldots \ldots \ldots 214$

Plural commissioner system $(1721-1723) \ldots \ldots \ldots \ldots \ldots 215$

Trouble with Virginia traders............ 216

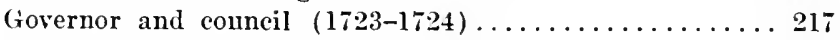

Single commissioner system $(1724-1751) \ldots \ldots \ldots \ldots \ldots 217$

Governor, council, and assembly (1751-1752) ....... 218

Single commissioner system $(1752-1756) \ldots \ldots \ldots \ldots .218$ 
Dispute with Georgia ................... 218

Dispute between the governor and assembly......... 219

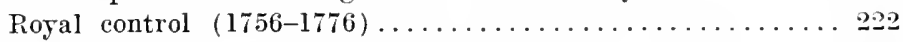

Establishment of the two superintendencies $(1 ; 56) \ldots \ldots$. 20

Extension of powers $(1764) \ldots \ldots \ldots \ldots \ldots \ldots \ldots \ldots \ldots \ldots \ldots$

Regulation of trade $(1764-1768) \ldots \ldots \ldots \ldots \ldots \ldots \ldots .225$

CHAPTER VI. Fixaxcial Histor:

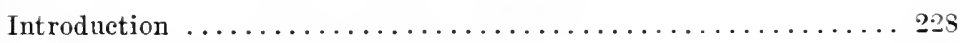

Meaning of Financial History .................

Financial staties and dynamies ................2s

A. Monetary System ....................... 229

Various mediums of exchange in use............ 229

English coins $\ldots \ldots \ldots \ldots \ldots \ldots \ldots \ldots \ldots \ldots \ldots \ldots \ldots \ldots$

Produce ........................... 20

Spanish, Mexican, and Perurian coins. Proclamation money.. 230

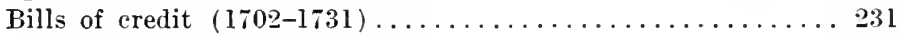

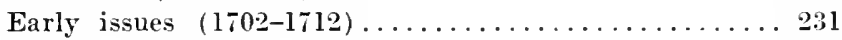

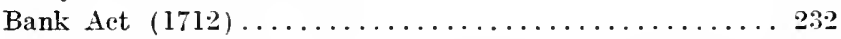

Subsequent issues of the proprietary and revolutionary

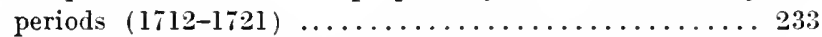

Struggle between council and assembly over the currency question $(1721-1731) \ldots \ldots \ldots \ldots \ldots \ldots \ldots \ldots .234$

Nicholson's administration $(1721-1725) \ldots \ldots \ldots \ldots 234$

$£ 120,000$ act $(1722) \ldots \ldots \ldots \ldots \ldots \ldots \ldots \ldots \ldots$

Imprisonment of merchant petitioners........ 236

Repeal in England.................. 240

Sinking fund act $(1724) \ldots \ldots \ldots \ldots \ldots \ldots . \ldots 24$

Middleton's administration $(1725-1730) \ldots \ldots \ldots \ldots 241$

Efforts of assembly to

(a) Evade sinking fund act..........243

(b) Issue new bills.............. 245

Johnson's administration $(1730-1735) \ldots \ldots \ldots \ldots . \ldots 6$

Appointment .................. 68

Currency problem before the Board of Trade.... 269

Solution of problem $(1731) \ldots \ldots \ldots \ldots \ldots \ldots 271$

Sinking fund law suspended.......... 27:

Public orders issued to pay provincial debts. 272

Dispute over President Middleton's salary 273

Bills of credit reissued............. 273 
Attempts to increase currency after $1731 \ldots \ldots \ldots \ldots \ldots .274$

Parliamentary restrictions .............. 275

Public orders $(1731-1770) \ldots \ldots \ldots \ldots \ldots \ldots \ldots \ldots \ldots \ldots .275$

Struggle between Governor Glen and the assembly...... 275

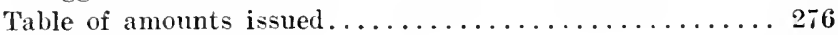

Purposes of issues..................... 277

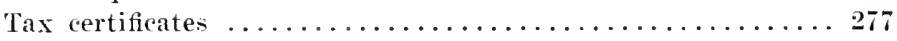

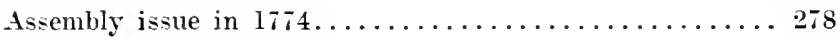

Summary of monetary system..................

B. Revenue Srstem . . . . . . . . . . . . . . . . . $\mathbf{2} 9$

Financial statics. Sources of revenue............. 279

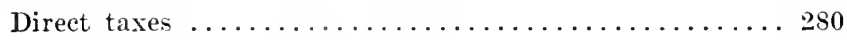

Procedure in framing tax bills.............. 280

Analysis of a bill................. 282

Apportionment between Charleston and the country 289 Articles taxed ................. 282

Method of assessment and collection....... 282

Amount raised by direct taxation............ 284

Import and export duties $\ldots \ldots \ldots \ldots \ldots \ldots \ldots \ldots \ldots .285$

Sketch of tariff legislation............... 28.5

Attempts to encourage ship-building......... 286

Specific appropriation of tariff receipts......... 287

Amount raised .................... 287

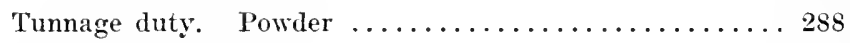

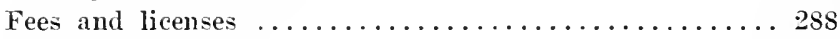

Fines and forfeitures $\ldots \ldots \ldots \ldots \ldots \ldots \ldots \ldots \ldots \ldots$

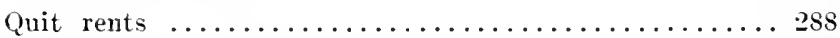

Total revenues for year $1746 \ldots \ldots \ldots \ldots \ldots \ldots \ldots . \ldots 28$

Financial dynamics. Struggle over money bills (1721-1;60) . 289

Council examines accounts and amends money bills (17.21-

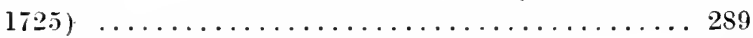

Dispute over allowance to Boone and Trott....... 289

Salary of the council clerk.............. 290

Renewed dispute over Boone's allowance........ 290

Assembly denies right of couneil to amend (1725-1736) . 291

Ammual tax bill of $1725 \ldots \ldots \ldots \ldots \ldots \ldots \ldots \ldots . \ldots \ldots$

Legislative procedure . . . . . . . . . . 291

Speaker Broughton's interpretation of the governor's thirty-fifth instruction............ 294 
Annual tax bill of 1735. Dispute over salary of the chief justice .................... 295

Pinckney resolutions ................ 296

Assembly denies right of council to examine the accounts

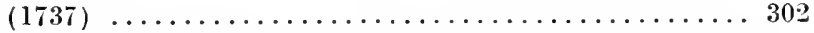

Assembly committee supervises public expenditures (1737) 305

Three constitutional advances. William Bull's administration $(1737-1743) \ldots \ldots \ldots \ldots \ldots \ldots \ldots \ldots \ldots \ldots \ldots \ldots \ldots$

(a) Governor excluded from the legislative council

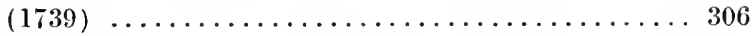

(b) Extension of the assembly's control over money

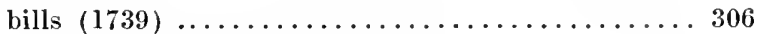

Change in legislative procedure ........... 311

(c) Assembly controls the election of the public treas-

urer $(1743)$.......................... 312

Administration of Governor Glen $(1743-1756) \ldots \ldots \ldots 314$

General character of his administration ......... 314

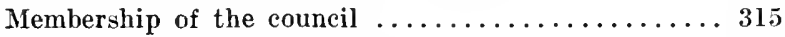

Dispute over tax bill for $1745 \ldots \ldots \ldots \ldots \ldots \ldots \ldots \ldots 315$

Council amendments disregarded........... 316

Assembly refuses to confer with the council on the

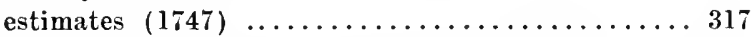

Right of council to suggest amendments denied (1748) 318

Extensive claims of the assembly ........... 319

The council defines a money bill (1749) ......... 320

Governor Glen vetoes a tax bill (1753) ......... 321

Dispute over the colonial agency $(1753-1756) \ldots \ldots 321$

Resolution of March 21, 1755.......... 32:

Administration of Governor Lyttleton (1756-1760) .... 325

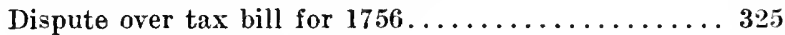

Assembly wins a victory............. 325

Right of council to sit as an upper house denied..325

General character of Lyttleton's administration..... 327

Summary ........................... 327

Chapter VII. The Downfall of Royal Goversment (1760-1776)

General character of the period before $1760 \ldots \ldots \ldots \ldots \ldots \ldots$

General character of the period after $1760 \ldots \ldots \ldots \ldots \ldots \ldots \ldots \ldots$

Sone reasons for the failure of the new imperial system.... 331 
xvi

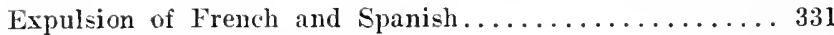

Sentiment of union. Intercolonial wars.......... 331

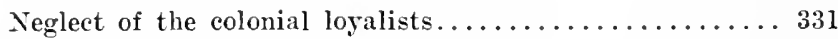

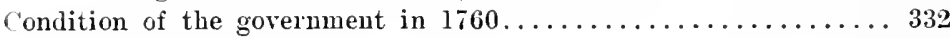

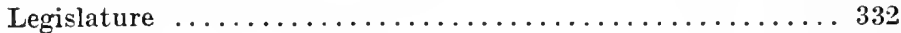

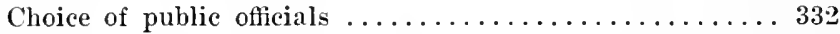

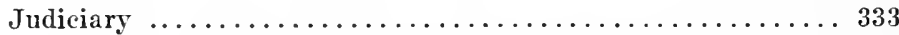

Judges dependent on British government after $1735 \ldots \ldots 334$

Executive ...................................... 334

Described in letters of Governor Glen to the Duke of

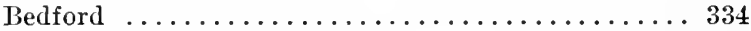

Encroachments of the assembly............ 335

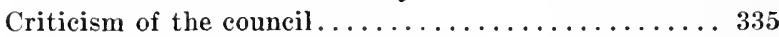

Example of the governor's weakness .......... 336

Contrast between the government in 1670 and $1760 \ldots \ldots \ldots \ldots . \ldots 336$

First administration of Lieutenant-Governor William Bull, the

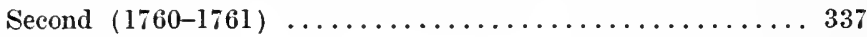

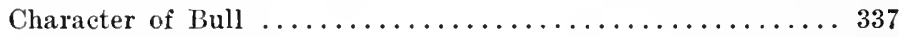

Dispute over the duty bill.................. 338

The Gadsden election case $(1762-1764) \ldots \ldots \ldots \ldots \ldots \ldots \ldots \ldots 340$

Administration of Governor Boone $(1761-1764) \ldots \ldots \ldots . \ldots 339$

Boone checks encroachments of the assembly upon the ex-

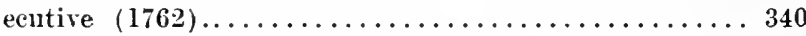

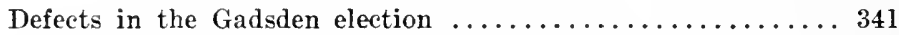

Governor refuses to administer the state oaths.......... 342

Assembly dissolved. New election................. 342

Report of the committee on privileges and elections....... 343

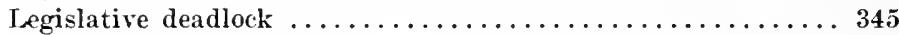

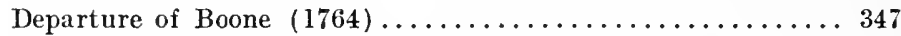

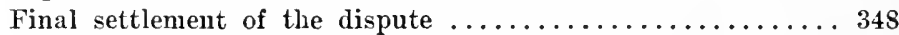

Boone's salary paid after a long delay (1766) ........ 348

Committee of assembly appointed to administer state

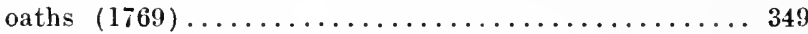

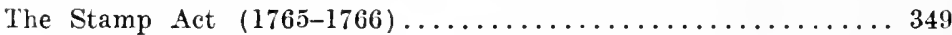

Second administration of William Bull (1764-1766) ......349

South Carolina and the Stamp Act Congress (1765) ....... 350

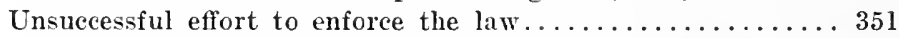

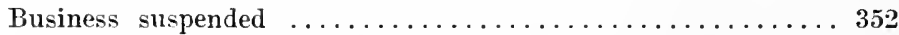

Bull raises the embargo. Advice of Surveyor-General Randolph 352

Attempt to open courts of justice............... 353 
Assistant justices appointed............... 353

Case of Jordan vs. Lax.................... 354

Clerk Campbell refuses to enter the judgment......... 354

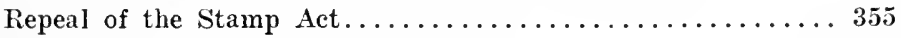

Campbell fined for contempt of court.............. 356

Chief Justice Skinner suspended (1767) ............. 356

Assembly refuses to furnish supplies for British troops (1769) ... 358

Administrations of Montagu and Bull (1766-1769) ....... 358

Governor Montagu requests aid for troops........... 358

Letters of Major Chisolme and General Gage.......... 358

Assembly refuses the request.................. 359

Troops not used for frontier defense............. 359

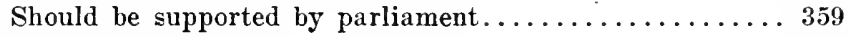

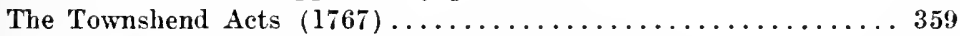

The Massachusetts circular letter (February 11, 1768) . . . . 359

The Virginia circular letter (May 9, 1768).......... 360

Reception of the letters in South Carolina............ 361

Speaker Manigault sends replies............... 361

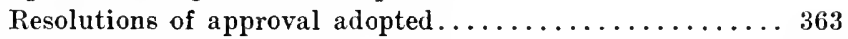

Assembly dissolved ........................... 364

New election. Report of committee on grievances....... 364

Fourth administration of William Bull (1769-1771) ..... 366

Parliamentry resolutions of February, 1769. Treason trials... 366

Virginia resolutions of May $16,1769 \ldots \ldots \ldots \ldots \ldots \ldots . \ldots 36$

Adopted by South Carolina assembly (August 19, 1769) . 367

Non-importation agreement ................. 368

The Wilkes fund controversy..................... 369

Assembly order and resolution of December $8,1769 \ldots \ldots \ldots \ldots 369$

Bull's letter of explanation to home government........ 370

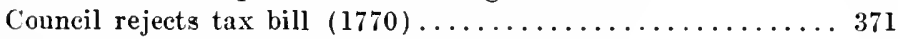

Report of Attorney-General William de Grey.......... 372

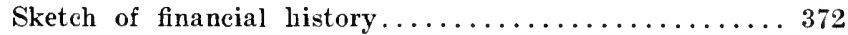

The additional instruction of April 14, 1770.......... 373

Assembly resolves not to comply with the instruction....... 374

Two theories of the colonial constitution............ 375

Attempt to entrap Lieutenant-Governor Bull......... 377

Third administration of Governor Montagu (1771-1773) ... . 379

Legislative deadlock $\ldots \ldots \ldots \ldots \ldots \ldots \ldots \ldots \ldots \ldots \ldots \ldots \ldots$

Dispute with public treasurers. Assembly dissolved....... 379

The Beaufort assembly $\ldots \ldots \ldots \ldots \ldots \ldots \ldots \ldots \ldots \ldots \ldots \ldots$ 
Montagu's quarrel with the lower louse.......... 3s?

The thirty-third and last assembly of the royal period (1733-

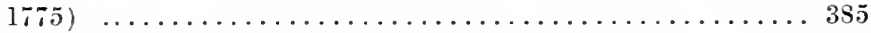

Growth of the spirit of rebellion $(1773-1755) \ldots \ldots \ldots \ldots \ldots \ldots 35$

Attack on the legislative powers of the council $(1 / 73) \ldots \ldots .38 \pi$

Sketch of previous attacks.................. $38 \mathrm{i}$

Council opposes attempts of assembly to pass laws..... 3ss

Personnel of the council in $173 \ldots \ldots \ldots \ldots \ldots \ldots \ldots \ldots 389$

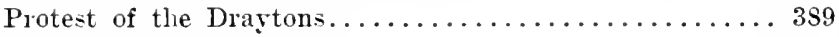

Arrest of printer Powell.................. 390

Arguments of Speaker Lowndes and Colonel Powell...... 390

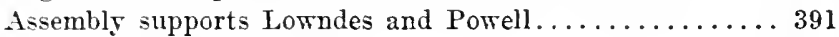

Case of Pouell vs. Leigh.................. 392

Assembly issues certificates to public creditors $(1774) \ldots \ldots 393$

Drayton suspended from the council $(1774-1775) \ldots \ldots \ldots \ldots 394$

Drayton appointed assistant justice............. 395

The Freeman letter ...................... 395

Criticism of judiciary. Dispute with Chief Justice

Gordon ......................... 396

Scheme of the assembly to evade the additional instruction 397

Drayton again enters protest on council journals....... 398

They request his suspension............... 398

Native councilors enter their dissent ............ 399

Drayton's remonstrance ................... 400

Questions legislative power of the council...... 400

Drayton suspended ....................4 401

Fall of royal government.................. 402

Administration of Lord William Campbell (1775) ..... 402

Development of the union sentiment............... 40 2

Intercolonial committees of correspondence $(1 ; 73-1774) \quad 402$

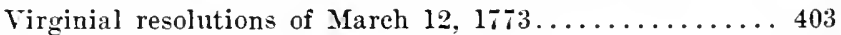

South Carolina committee (July 8 ) ............ 403

Other colonies appoint committees............. 404

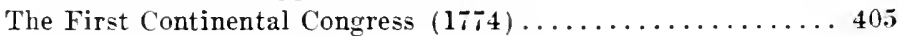

Election of delegates................... 405

Assembly provides for expenses............... 406

Asiembly approves action of the congress......... 406

The Second Continental Congress $(1755-1781) \ldots \ldots \ldots \ldots 407$

Birth of the American nation.................40 


\section{TABLE OF CONTENTS}

APPENDIX 409

General Assemblies of the Royal Period.............4409

Colonial Officials of the Royal Period............. 410

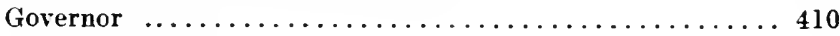

Public Treasurer ..................... 411

Powder Receiver ......................411

Secretary of the Province................ 411

Commissary General .................. 411

Provost Marshal ........................4 412

Attorney-General ......................412

Surveyor-General of Lands............... 413

Receiver-General of the Suit Rents............413

Chief Justice ....................... 413

Judge of the Court of Vice-Admiralty........... 414

Speaker of the Assembly ................. 414

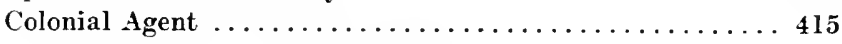

Superintendent of Indian Affairs ............ 416

List of Authorities...................... 417

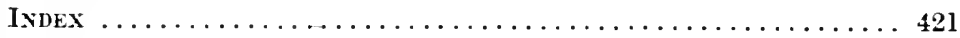





\section{SOUTH CAROLINA AS A ROYAL PROVINCE}

\section{INTRODUCTION}

\section{The Proprietary Period (1670-1719)}

History can best be studied and best be written when some central thread of interest exists about which all the facts may be grouped and by which they are to be interpreted. In colonial history this thread is to be found in the continual conflict between two opposing tendencies, represented by two clearly defined parties: the tendency toward imperial control, represented in the provinces by the governor, council, and other crown officials; and the tendency toward independence, represented by the popular branch of the colonial legislature. According to the prevalence of the one or the other, the colony would sink into a mere dependency without popular representation or would develop into a commonwealth independent of the mother country.

These tendencies were at work in all the colonies, but the struggle assumed a different form in the two great classes of colonies, the corporate and the provincial. ${ }^{1}$ In the former the popular element was

1 For the classification of colonial governments, see Osgood, Pol. Science Quarterly, XI, 259-263. Also his articles on the Proprietary Province, American Hist. Revieu, II, 644-664; III, 31-55, 244-265. 
predominant from the outset, and little was needed to break off the shadowy dependence and complete the transition into a commonwealth. In the provinces, however, the prerogative element was strong. The proprietor, whether the king, a private individual, or a proprietary board, was the head of the government and lord of the territory. Hence the people were tenants as well as subjects and there was a double cause for conflict. The corporate colony existed only in New England. South Carolina was always a province, proprietary until 1719, and royal until 1776 . Its history is the story of an uninterrupted conflict and of the gradual triumph of the popular over the prerogative element.

The plan of this work is as follows: First, a brief introductory chapter on the proprietary period with special reference to the encroachments of the assembly on the rights of the proprietors, culminating in the revolution of 1719. Then follows a section on the land system, dealing with the proprietors as territorial lords, especial attention being devoted to land frauds and the controversy over quit rents. Finally, comes a section on the government treating of the executive, legislative, and judicial departments, of the colonial agency, and of the military and financial systems. An attempt is made to describe the governmental system as established by commissions, instructions, and statutes, and to show how it was modified in the direction of greater popular control when put into actual operation. The period covered is in the main that previous to 1760 . The concluding chapter begins with the accession of George III. to the British throne 
and ends with the downfall of royal government in South Carolina. The struggle between the prerogative and popular elements in the colony is discussed in some detail.

In the year 1629, Charles I. granted to his attorneygeneral, Sir Robert Heath, all the territory lying between the 31st and 36th parallels of north latitude and extending through from sea to sea. ${ }^{1}$ No settlement was made under this patent, and in 1663 the same territory was granted to eight of the favorites of Charles II. A second charter in 1665 extended the limits to $29^{\circ}$ and $36^{\circ} 30^{\prime} .^{2}$ The proprietors were to legislate for the colony "by and with the advice, assent, and approbation of the freemen." They were also empowered to grant such dispensations and indulgences to dissenters as in their discretion they should think fit and reasonable, and such persons were not to be disturbed in religious matters so long as they kept the civil peace. This was not a guarantee of religious liberty, but merely a permission to the proprietors to grant it or not at their own discretion. ${ }^{3}$ The proprietors were to hold by free and common socage and the statute quia emptores was set aside, thus allowing subinfeudation.

The proprietors at first decided to offer very liberal terms to induce settlers to go out. By their concessions of 1663 and 1665 the freemen were guaranteed religious freedom, given a large share in the government, and

I N. Car. Col. Records, I, 5-13.

${ }^{2}$ Ibid., 20-33, 102-114.

$3 \mathrm{McCrady}$ in his treatment of the religious controversy in 1704 calls attention to this fact. S. Car. under Prop. Govt., 410. 
empowered to create courts of justice. ${ }^{1}$ No permanent settlement was made under these articles, and in 1669 the proprietors changed their policy and adopted a new system essentially monarchical in its nature. It would be useless to discuss in detail the cumbersome scheme outlined in the Fundamental Constitutions, inasmuch as it could never be carried out and had little effect except upon the land system. ${ }^{2}$

The board of proprietors held a meeting in April, 1669 , and decided to contribute $£ 500$ each toward fitting out an expedition. ${ }^{3}$ Three shiploads of colonists set sail with orders to go by way of Barbadoes, receive instructions from Sir John Yeamens and Mr. Thomas Colleton, and then proceed to Port Royal, where the settlement was to be made. After many adventures the settlers reached Port Royal in March, 1670, but becoming dissatisfied, moved up the coast and settled on the west bank of the Asnley river. ${ }^{5}$

Lands were laid off, fortifications were erected, and a government established, in accordance with the instructions to Governor Sayle. There was to be a grand council of ten members, one-half deputed by the proprietors and the other half elected by the freemen.

1 1 . Car. Col. Records, I, 43-46, 75-93. These documents are known as the Barbadoes Concessions, their object being to secure settlers from Barbadoes.

2 For the first set, that of July, 1669, see the Shaftesbury Papers, S. Car. His. Soc. Col., V, 93-117; for the second set, March, 1670, $\mathrm{N}$. Car. Col. Records, I, 187-206.

3 Shaftesbury Papers, S. Car. His. Soc. Col., V, 91-93.

- Ibid., 123-124, 129.

5 Ibid., 167, 173, 19-193. 
This was intended primarily as an executive body. The freeholders were also to elect a parliament of twenty members, who, with the five deputies of the proprietors, were to constitute the legislative body.' Alleging the small number of colonists as an excuse, Governor Sayle at first refused to call a parliament, and the grand council took upon itself the entire administration of affairs, legislative, executive, and judicial. Two popular leaders, William Owen and William Scrivener, became dissatisfied and tried to foment a disturbance. ${ }^{2}$ Matters were quieted by the arrival in May, 1671, of a second set of instructions to the governor, which again required him to call a parliament. ${ }^{3}$ This apparent victory was practically nullified by an additional instruction in December which provided that all legislative measures must originate in the grand council and then be sent to the parliament for its simple approval or rejection. ${ }^{*}$ The history of the province for the next hundred rears consists largely of tracing the process by which the positions of these two bodies became reversed. By 1771 the council had become the mere figurehead, and the assembly had become supreme.

It would be impossible, without taking up considerable space, to treat this period in detail; hence we can give only a few facts and attempt to show the general tendency in the development of the province. ${ }^{5} \quad \mathrm{~A}$ few

1 Shaftesbury Papers, S. Car. His. Soc. Col., V, 120-121.

2 lbid., 290-295.

s Ibid., 322-323.

I Ibid., 367 .

${ }^{5}$ For detailed accounts see Rivers, Sketch of the History of S. Car. and MeCrady, S. Car. under Prop. Gort. 
words should first be said in regard to the growth of the colony and the character of its population. The original settlement, made in the spring of 1670 , contained less than two hundred souls. ${ }^{1}$ Many others soon began to arrive, especially from England and the Barbadoes. In 1680 the white population had increased to $1200,{ }^{2}$ and in 1700 to $5500 .{ }^{3}$. The number of slaves at this time is not given, but by 1708 they formed a majority of the population. The early settlers were mostly pure English, Barbadians, and French Huguenots. They settled along the coast north and south of Charleston and did not penetrate far into the interior. The province was soon divided into three coast counties: Berkeley, extending from the Stono river to the Sewee, and including Charleston; Craven to the north of the Sewee; and Colleton to the south of the Stono.

In 1680 the settlement was removed from the west bank of the Ashley to the site of the present city of Charleston on the neck between the Ashley and Cooper rivers. From the very beginning Charleston was the political and social center of the province. Here resided the governor, council, and most of the provincial officials. Here for a time were held all elections, and for a still longer time all courts of justice. In short, until within a few years of the Revolution, the will of the town was, politically speaking, the will of the province.

1 Shaftesbury Papers in S. Car. His. Soc. Col., V, 156, 163.

2 Carroll, His. Col. of S. Car., II, 82.

${ }^{3}$ Rivers, Sketch of the His. of S. Car., 443. See MeCrady, S. Car. under Prop. Govt., 722, for table of population at different times. 
To return to the field of politics, we may roughly divide the proprietary period into three sub-periods. The first, extending to 1700 , was characterized by a protracted conflict between the representatives of the people in parliament, aided by the elected element in the grand council on one side, and the governor and deputies of the proprietors on the other. The principal questions at issue were the refusal of the people to subscribe to the numerous editions of the Fundamental Constitutions, the attempts of the proprietors to give to the new and as yet sparsely settled counties of Craven and Colleton a representation in parliament equal to that of Berkeley county, and finally a controversy over the quit rents. The settlement was reduced almost to a state of anarchy, and the proprietors were compelled to make concessions. The result was a gradual change in the colonial constitution and a development in the direction of greater popular control over the government.

It has already been stated that the plan of government as first established gave the grand council the sole power to initiate legislation. The proprietors sent out an instruction in 1682 providing that the major part of the grand juries of the counties might present suggestions suitable to be passed into laws, and that, if the grand council did not propose them in a suitable time, they might be considered in parliament without further action. ${ }^{1}$ In 1692 the parliament seems to have been finally divided into two houses and the elective element disappeared from the council. ${ }^{2}$ The struggle was now

1 Rivers, Sketch of the His. of S. Car., document in appendix, 396.

${ }^{2}$ Com. House Journals, Ms., I, 1; Statutes, II, 72, 74. 
to be one between the popular house of assembly and the appointed governor and council. A long and rancorous debate over the power of initiation set in, which was finally settled, May 15, 1693, by the following message from Governor Smith to the house of assembly: "Gentlemen, I thank God I have reason to hope that many things which formerly were obstructions to the dispatch of Publique affairs in the way of Parliaments or Assemblys are removed; the Lords Proprietors having consented that the proposing power for the making of Laws which was heretofore lodged in the Grand Council only is now given to you.",

A controversy over the quit rents soon became the all-absorbing topic of interest. The colonists were almost on the point of open rebellion when Governor John Archdale arrived in 1695 with specially enlarged powers to restore harmony. He permitted the passage of a liberal quit rent law, the last clause of which declared it "unrepealable and irrevocable by any power or persons whatsoever, without the consent of the General Assembly.", 2

Archdale was succeeded in 1696 by Deputy Governor Blake, who governed until 1700. Thanks to the beneficent settlement of Archdale, these were years of peace. With the close of the century, colonial politics entered a new phase. Archdale's law put at least a temporary check to the disputes over quit rents and land tenures, and the proprietors had given up all attempts to en-

${ }^{1}$ Com. House Journals, Ms., I, 50. Rivers gives the date of this message incorrectly as May 15, 1694, sketch of the His. of S. Car., 171.

2 Statutes, 1I, 96-102. See p. 30. 
force the Fundamental Constitutions. The result was the dissolution for the time being of the old parties, which we may call the proprietary party and the people's party. The four rears of Blake's administration constituted a period of transition in which new issues were coming to the front. Religion was now becoming the basis of party division, hence we find churchmen and dissenters opposing one another. The wealthy inhabitants of Berkeley county, who were for the most part churchmen, had ten representatives in the assembly. The Colleton county dissenters likewise had ten members. The French Huguenots of Craven county, with their ten members, held the balance of power. They were inclined to ally themselves with the church party; hence the dissenters attempted to disfranchise them on the ground that they were aliens. Blake, who was a dissenter, was succeeded in 1700 by James Moore, a high churchman. The contest soon became bitter. Moore's expedition against St. Augustine was made a party question, and its failure mar have been partly due to the opposition of the dissenters.

In 1703, Sir Nathaniel Johnson, a bigoted high church Jacobite, arrived in the country with a commission as governor. Matters soon came to a head. By a close vote a test act was passed, May, 1704, requiring members of the assembly to conform to the Church of England and receive the sacrament according to the rites and usages of that church. ${ }^{1}$ In this may be seen the influence of English politics, which were then being agitated by the bill to prevent occasional conformity.

I Statutes, II, 232-235; Com. House Journals, Ms., II, 241-242, 245, 267. 
Just as in England, dissenters and moderate churchmen opposed the measure. Conspicuous among the latter class was the Reverend Edward Marston, rector of St. Philip's, Charleston. He openly attacked the policy of the government from his pulpit, and they retaliated by depriving him of his yearly salary. ${ }^{1}$ The victorious party now pushed on, and in November of the same year passed an act for the establishment of the Church of England in the province. ${ }^{2}$ After providing for the division of Berkeley county into six parishes, the erection of churches and the maintenance of ministers, the act went on to provide for a lay commission of twenty members for the trial of ecclesiastical cases. $^{3}$ This was directed against Marston, but it was a great blunder for it encroached upon the jurisdiction of the Bishop of London. The dissenters sent Mr. Joseph Boone to England as special agent to petition the proprietors against the bills. The palatine, Lord Granville, was a violent partisan of the act against occasional conformity, which had recently been defeated in parliament for the third time, and he gladly approved these colonial statutes. Failing to get relief here, Boone appealed to the Whig House of Lords in a memorial, which, with great adroitness, laid special stress upon the interference with the jurisdiction of the Bishop of London. ${ }^{*}$

1 Rivers, Sketch of the His. of S. Car., 220.

${ }^{2}$ The church had not yet been formally established, though the Charleston minister had for some time been receiving a salary from the government.

Statutes, II, 236-246.

'Rivers, Sketch of the His. of S. Car., Appendix, 461-463. 
On March 12, 1706, the Lords presented an address to Her Majesty asking that South Carolina should be relieved of its misfortunes. ${ }^{1}$ The address was referred to the Board of Trade, which reported, on the advice of the attorney-general and solicitor-general, that the acts were repugnant to the laws of England and not warranted by the charter, and that therefore the queen should declare them null and void and require the proprietors to abrogate them. They further suggested that the queen might proceed against the charter either by writ of scire facias in chancery or by quo warranto in the queen's bench, provided the said acts had been approved by the proprietary board. ${ }^{2}$ The proprietors saved themselves by showing that only a minority of the board had given their approval.

The colonial assembly passed an act, November 30 , 1706 , to repeal all laws in regard to the church and at once enacted a new law for the establishment of religious worship according to the Church of England, which made no reference to a lay commission or to a religious test for membership in the assembly. ${ }^{3}$ This act, with some additions and amendments, remained in force until the Revolution. It divided the province into ten parishes named after those of Barbadoes. In 1721 the parishes were finally made the election unit for members of the lower house of assembly.

The settlement of the church controversy was followed by a few years of quiet and prosperity, and then

1 N. Car. Col. Records, I, 635-637.

${ }^{2}$ Public Reeords, Ms., V, 15i-159.

3 Statutes, II, 281-294. 
came another attack on the proprietors, which ended with the revolution of 1719 and the overthrow of the proprietary government. The causes that led to this revolt were briefly as follows: In the year 1715, the Yemassee Indians, instigated by the Spanish at St. Augustine, made an attack on the South Carolina settlements. The little band of colonists struggled with great valor, but were soon reduced to a state of despair. Agents were sent to England to ask aid of the proprietors. On their refusal to help, application was made directly to the crown. The Board of Trade reported that they could not assist the province unless its government were vested in the crown. The colonists were thus compelled to continue the contest without assistance from abroad. They begged the king to take the province under his own control and protect them from their enemies.

Numerous other grievances gave added strength to the spirit of revolt. An act of 1717, making the parish the unit of representation in the lower house, was promptly vetoed by the proprietors and the old method of electing all the representatives at Charleston was restored. This was a grievance, not only because of the great distance necessary for the electors to travel, but because of the opportunity it gave for intimidation and manipulation of elections by a small official clique, then led by Chief Justice Nicholas Trott and his brother-in-law William Rhett. Trott, who was a learned lawyer and the occupant of numerous salaried positions, kept up a constant correspondence with the proprietors and had more influence with them than the 
governor had. On his advice, a number of laws dear to the people were disallowed by the proprietary board, as, for example, an act regulating the Indian trade and an act disposing of the captured Yemassee lands. $\mathrm{He}$ became an object of popular hatred, and thirty-one articles of complaint against him were presented to the assembly. The most important of these was that he held a monopoly of judicial positions, which he did not hesitate to use for partisan purposes. He was sole judge of the courts of common pleas, of king's bench, and of vice-admiralty, and a nember of the council, hence also of the court of chancery.

Governor Johnson and the council saw that trouble was brewing and sent one of their number, Mr. Francis Yonge, to England to urge the proprietors to remove Trott from his offices and to make concessions in regard to election laws, Indian trade, and other grievances. The proprietors refused to heed the advice and sent Yonge back with a letter of thanks to Trott for his zeal in their behalf and also an order creating a new council of twelve, from which those old members who had sided with the people were excluded. The popular party objected to this council on the ground that there were twelve members, whereas there had before this been only seven, one deputy for each proprietor. ${ }^{1}$

On December 10, 1719, an assembly met which had been elected entirely at Charleston according to the old election laws. On meeting, they resolved that the elec-

1 The governor was the palatine's deputy. At the first settlement of the province there were only five proprietary deputies, but the number was increased to seven, probably in 1692 when the popular element was eliminated from the council. 
tion act recently passed by them was still in force in spite of the proprietary repeal, and that, as a result, they could not legally constitute an assembly. Another reason was that the new council which had issued the election writs was illegal in that it had twelve members instead of the customary seven. They then resolved themselves into a convention and proceeded to organize the revolt. An attempt was made to induce Governor Johnson, who was personally popular, to take upon himself the government in the king's name. On his refusal, Colonel James Moore was chosen governor to serve until the king's will could be known.

The revolution was accomplished with very little difficulty because the rumor of a Spanish invasion had made it necessary for the governor to call together the provincial militia. The militiamen almost unanimously signed an association to stand together in an effort to bring the government under the rule of the king. Supported by this armed body the convention was supreme. They chose a governor and council, and voted themselves to be an assembly. As such they passed laws and ordinances and appointed officials. Moore continued to act as governor until May, 1721, when Sir Francis Nicholson arrived with a commission from the king. The colony remained provisionally under the crown until 1729 , when, by an act of parliament, the rights of the proprietors were bought out and South Carolina became a royal province. ${ }^{1}$

1 This account of the revolution is based upon Yonge's narrative in Carroll, His. Col. of S. Car., II, 141-192, and upon a petition from the council and assembly to the king, dated February 3, 1720, Public Records, Ms., VII, 271-299. 
During this third period of the proprietary era, we find few specific points in which the popular gained upon the prerogative element in the government, for the reason that the proprietors adopted a position of unyielding obstinacy. Concessions were refused and revolution was the natural result. The total overthrow of proprietary rule was of course a decided triumph, and it afforded a valuable precedent when it became necessary later for the people to revolt against the king himself. There were, however, two important victories gained by the commons. In the first place, they secured the power of appointing all public officials paid out of the colonial treasury. The public receiver, or treasurer of the province, had, as far back as 1691 and probably earlier, been chosen by the co-operation of the three branches of the legislature in the form of a statute. $^{1}$ Mr. George Logan had thus been appointed by the duty act of $1703,^{2}$ which in 1704 was continued to May 10,1707. ${ }^{3}$ He took the part of the dissenters in the church controversy and thus incurred the enmity of Governor Johnson. When the time came for electing his successor in 1707 , the commons house, a majority of whose members were now dissenters, determined that he should succeed himself. Governor Johnson refused to approve him and suggested Major Parris for the place. ${ }^{4}$ The commons charged the governor with trying to "abridge the House of Commons of their just right of ordering all things relating to the disposall

1 Statutes, II, 65; Com. House Journals, Ms., I, 253-254.

2 Statutes, II, 204.

${ }^{3}$ Ibid., 247.

- Com. House Journals, Ms., III, 237-239. 
of the Publick Money,' and declared that such matters had much better be in the hands of the representatives of the people than in those of governors, who were often "needy courtiers come abroad to enrich themselves." They rejected Mr. Parris and insisted upon the re-election of Logan. ${ }^{2}$ A long and bitter dispute ensued, in the course of which Johnson suggested that they agree upon a third party to fill the office temporarily until the Lords Proprietors could be consulted. ${ }^{2}$ The reply was that they could not think of making their lordships judges in the matter inasmuch as they were interested parties. They were quite willing, however, to put the question to a final issue before the queen and parliament. ${ }^{3} \quad$ This sounds like a breach of fidelity to the proprietors, but as the representatives of the people had so recently been successful in their appeal on the religious question, it is natural that they should indulge in such threats. Johnson consented to submit the affair to the queen and parliament, and suggested a plan for a temporary compromise. He agreed to recognize for the time being the sole power of the commons to elect the public receiver, provided they would not choose Mr. Logan or any other person who had made himself personally obnoxious to the government during the recent troubles. ${ }^{4}$ The house refused to drop Logan and the governor was quite as determined not to accept him. Finally, on July 2, Logan removed the difficulty by

1 Com. House Journals, Ms., III, 240-243.

2 Ibid., 248.

sIbid., 250.

-Ibid., 250-25l. 
voluntarily withdrawing from the contest. ${ }^{1}$ On the same day, the assembly drew up and passed on its first reading "An Act declaring the right of the House of Commons for the time being to nominate the Publick Receiver." With considerable haste it was passed through its three readings in both houses and was ratified by the governor on the 5th. ${ }^{2}$ The act went further than the title indicated and conferred upon the lower house the sole power of appointing the public receiver, comptroller of the duties, powder receiver, and all other officials receiving a fixed salary out of the public treasury. $^{3} \quad$ The house at once elected Captain George Smith receiver and the governor sent down a message signifying his approval. They replied tartly that it made no difference to them whether he approved or disapproved of their choice. ${ }^{4}$

The law was put to a test a few years later in a dispute over the appointment of a powder receiver. The duty of this official was to collect the tunnage rate of one-half a pound of gunpowder per tun, or the money equivalent, on all vessels coming into the ports, creeks, or harbors of the province. The earliest extant law for levying this rate, that of January 22, 168i, allows the governor to appoint the receiver. ${ }^{5}$ He seems to have had this power up to 1698 when Mr. Thomas Howard was named as gunner and receiver in the act

1 Com. House Journals, Ms., III, 256.

2 Statutes, II, 299. Title only.

3 Com. House Journals, Hs., V, 402.

I Ibid., III, 259-260.

5 Statutes, II, 20-21. 
itself. $^{1} \quad$ The regular rule from this time until the passage of the act of 1707 was for the receiver to be thus appointed, nominally by the concurrent action of governor, council and assembly. As early as 1701, however, it began to be the custom for the lower house to nominate, while the governor and council merely approved or disapproved of their choice. This arrangement was recognized by the governor, as will be seen from the following message to the commons: "We do not approve of Mr. John Crosskeys for Powder Receiver, and desire that you nominate more than one for our approbation.",

Captain Matthew Porter, who had been powder roceiver for several years, died in November, 1717. Governor Johnson at once appointed Major William Blakeway to succeed him and requested the house to confirm his choice by an act of assembly:3 In answer to this they used the following language: "As we find by perusal of the laws of this province, that the person to act in that station is to be nominated by and solely in the disposal of the House of Commons, we shall speedily take such measures relating to that affair as are conformable to the same." His Excellency replied that he and the council had perused the laws and were of a different opinion. Accordingly, he desired a committee of the two houses to confer on the subject. The

I Statutes, II, 151. William Smith was mentioned as powder receiver in an act of 1695 , but the context implies that he had already been appointed by the governor and had given security for the performance of his duties. Ibid., 83.

${ }^{2}$ Com. House Journals, Ms., I, 407.

s Itid., V, 380 . 
commons expressed the hope that he would allow the matter to be settled solely by their house as the law directed. Governor Johnson retorted by saying that the appointment of a powder receiver was a branch of the military power and as such vested solely in the governor, who was His Majesty's captain general. However, he and the council were willing that the assembly should pass an act electing the gentleman whom he had already appointed. If they refused, he would adhere to his undoubted right and appoint such person as he thought proper. Immediately on receiving this message, the house resolved, "that Colonel Michael Brewton be and he is hereby appointed Powder Receiver in this Province." They further resolved that the law of 1707 gave them the undoubted right to the appointment and notified all ship-owners and others to regard Brewton as the legal receiver. Johnson sent down a message saying that he would consent that the house should nominate a powder receiver, but that the powder magazine must be in the hands of some one appointed directly by himself. Accordingly, he had given Major Blakeway a commission as commander of the fortifications, and he was to take charge of the magazine and give receipts to the powder receiver for such powder as he should receive. This meant that Brewton was to be collector of the powder duty, and Blakeway the custodian of it after collection. The house replied that they had no desire to nominate a powder receiver who was not to have the keeping of the powder, and that they had given orders to Brewton to deliver to the governor whatever powder he might need for the public 
service. Johnson suggested that if they could give such an order, they could as easily reverse it, and thus might wrest the government from the hands of the executive. He was compelled to yield, however, and Brewton became receiver with full powers. ${ }^{1}$

Jolinson must have submitted the whole matter to the proprietors, for they sent out an instrument, dated July 22,1718 , repealing the much-quoted act of $1707 .^{2}$ The repeal was disregarded and the law declared still in force by an act of February 12, 1720.3 In the enthusiasm over the establishment of the royal government. a statute was passed, 1721, again vesting the power of electing the treasurer, comptroller, powder receiver, and other officials in the general assembly. ${ }^{4}$ Our study of the royal period, however, will show that the share of the governor and council in the election was merely nominal and that they were often compelled to accept men who were obnoxious to them.

The other matter referred to was an extravagant claim rather than a definite encroachment, but it is of interest in showing the general trend of constitutional development. The commons house, November 9, 1717, sent the following message to the governor and council:

"May it please your Honors.

"This house for the expediting of the public business of this Province, has read the bill you sent to us yesterday and passed by you the first time with amendments; though we

1 Com. House Journals, Ms., I, 381, 384, 398-399, 402-403, 407-410.

${ }^{2}$ Statutes, II, 299.

${ }^{3}$ Ibid., III, 103; Public Records, Ms., VII, 143-144.

statutes, III, 14S-149. 
cannot but remind your Honor, that it ever was the practice, and is the undoubted right of this House, to have all bills whatsoever, to begin to be read the first time therein, and therefore shall ever hereafter insist upon the same practice being continued."'

In closing this chapter on the proprietary period, it may be well to summarize briefly the relative positions of the popular and the prerogative elements of the government in 1719. The popular branch of the legislature had secured the power of choosing and dismissing the public treasurer, the powder receiver, the commissioners of the fortifications, and all officers paid out of the public treasury. The accounts of these officials were regularly examined by committees from their house. They had practically the sole power of initiating legislation. Fees of public officials from governor down were regulated by statute. The control over church patronage, usually a perquisite of the governor's, was, by the act of 1706 , conferred upon the conforming inhabitants of the various parishes. ${ }^{2}$

${ }^{1}$ Com. House Journals, Ms., V, 361-362.

${ }^{2}$ Statutes, II, 288. 



\section{SECTION I \\ LA ND SYSTEM}





\section{CHAPTER I}

Origin and Developiext of the System Durisg the Proprietari Period

The province must now be studied as a fief, of which the king was territorial lord and the settlers were tenants. Just as in England, land grants took the form of a tenement rather than an allod and the ultimate ownership of all land was vested in the crown. The tenure was by free and common socage after the manor of East Greenwich, the chief obligations of which were fealty and the payment of a fixed rent. ${ }^{1}$ To understand with any degree of clearness the questions arising in connection with the relations between landlord and tenant it will be necessary to go back into the proprietary period and study briefly the origin and development of the land system.

The charters of 1663 and 1665 empowered the proprietors to grant lands in fee simple or fee tail, for a term of years or for life or lives to any persons they chose, and the grantees were to hold directly of them and not of the king. The statute quia emptores was accordingly declared inoperative. ${ }^{2}$

1 Blackstone, Commentaries, Book II, Chap. 6. For a detailed account of the province as a fief see Osgood, Amer. His. Review, II, 644664. Though the military tenure had only recently been abolished in England by the statute 12 Charles II, chapter 4, it was never introduced into any of the American colonies.

2 Statutes, I, 27-28, 37-38. 
The next step was for the proprietors to make known their terms to the prospective settlers. The Fundamental Constitutions contain a number of sections on the land system which show very clearly the feudal and aristocratic nature of that instrument. In the first place, the whole province was to be divided into counties, twelve to be laid out at once. Each county was to consist of eight seignories, eight baronies, and twentyfour colonies. ${ }^{1} \quad$ These divisions were to contain twelve thousand acres each. The seignories were to belong to the proprietors, the baronies to the colonial nobility, and the colonies, amounting to three-fifths of the whole, to be granted out to actual settlers. In each county were to be a landgrave with four baronies and two caciques with two baronies each. These were to constitute the hereditary nobility of the province and to have seats in parliament. Tracts of land containing more than three thousand and less than twelve thousand acres might be erected into manors by patent from the palatine's court. Provision was made for a registry in every precinct in which were to be enrolled all deeds, leases, and other territorial documents. After 1689 every freeholder was to pay to the proprietors a quit rent of a penny per acre or the value thereof. ${ }^{2}$

These provisions were of course very general in their nature. Details had to be regulated by instructions sent out to the governors from time to time. The commission to Governor Sayle, dated July 26 and 27, 1669, gave him and the major part of his council power to

1 Six colonies constituted a precinct.

${ }^{2}$ Statutes, I, 43-56. 
sell, let, and convey lands in Carolina in accordance with the annexed instructions and such others as should be sent later. These instructions stated that it would be impossible to put the Fundamental Constitutions into operation at once, and went on to provide certain temporary arrangements. One hundred and fifty acres of land were to be granted to every freeman coming out before March 25, 1670, one hundred and fifty more for every able man servant brought with him, one hundred for every woman servant or man servant under sixteen, and one hundred acres for every man servant after he had served his time; to those coming before March 25, 1671, one hundred acres and seventy acres respectively; before March 25, 1672, seventy and sixty respectively.

Perhaps the most interesting part of these instructions is to be found in those sections defining the method of procedure in taking out patents. The person applying for land first appeared before the governor and council and secured from them a warrant to the surveyor-general. The surveyor-general laid out the land according to the proportions mentioned in the instructions. Then the warrant, together with the surveyorgeneral's return, was recorded. Next, the applicant swore allegiance to the king and fidelity and submission to the Lords Proprietors and to the Fundamental Constitutions. The governor passed the grant under his seal, it was signed by him and by three members of the council, and finally recorded in the register's office. The form of grant is given in full. It provided that the land should be held of the proprietors in free and 
common socage in consideration of an annual rent of one penny lawful English money or the value thereof per acre, the first payment to be made on September $29,1690 .^{1}$

In the relations between the proprietors and their tenants there were two main questions at issue. In the first place, there were numerous land frauds, due in part to the provision for granting land in proportion to the number of servants and settlers brought into the province, but chiefly to the barony grants. Although the whole province was deeply and permanently affected, the immediate parties to this controversy were the proprietor's and a few of their leading tenants. The other question was much more general in its nature. Every freeholder in the province was a rent payer, and was directly interested in the method of collection and in the fixing of penalties for non-payment. The strenuous efforts made to secure regular payments resulted in a long and bitter controversy, which could not fail to have its effect on the constitutional development of the province.

The quit rent question was the first to give trouble. It will be remembered that, according to the Fundamental Constitutions and the instructions to Governor Sayle, the people were not to pay any rent until after 1689 , when they were to pay annually one penny per acre or the value thereof. In a form of grant sent over

IShaftesbury Papers, S. Car. His. Soc. Col., V, 117-123. The instructions provided for two special land officers, a surveyor-general and a register of deeds. Florence $O$ 'Sullivan, whose name is perpetuated in Sullivan's Island, was appointed surveyor-general and Joseph Dalton register. Ibid., 130-132, 182. 
in 1682, the words "or the value thereof" were struck out, which meant that rents were to be payable in money and not in produce. ${ }^{1}$ It was further provided in 1683, that if a tenant fell six months in arrears with his rent, the proprietor's could take possession of the land. Settlers were required to sign an indenture or contract containing these provisions. ${ }^{2}$ The colonists refused to sign and much disturbance was caused. In a letter to Governor Morton, dated April 26, 1686, the proprietors stated that these requirements were no more than those made in England, that the people could leave Carolina if they did not wish to pay rents, and, finally, that they intended to dispose of their own property as they saw fit. ${ }^{3}$

Matters went on from bad to worse; governor after governor found it impossible to serve the proprietors and gain the confidence of the people. Parties were formed, disputes were carried on in the legislature, and the culmination was reached in the overthrow of Governor Colleton in 1690. The proprietors were now compelled to make concessions to the popular party and they secured a larger share in the government. ${ }^{4}$ Finally, in 1695, the Quaker governor, John Archdale, was sent out with special powers to secure a harmonious settlement. He perceived that further concessions would have to be made, and, after considerable wrangling, gave his consent to two laws passed on

1 Public Records, Ifs., I, 151-152.

${ }^{2}$ Ibid., II, 98, 133-140, 145-149.

3 Ibid., 131-132.

- See the introductory chapter for further discussion. 
Mareh 16, 1696. The first was entitled, "An Act to ascertaine the Prices of Land, the forms of conveyances, and the manner of Recovering of Rents for Lands, and the Prices of the several Commodities the same may be paid in." This provided for two forms of deeds: in one case a rent of a penny per acre was demanded, in the other this rent was reduced to twelve pence per hundred acres in consideration of a small lump payment. ${ }^{1}$ Rents were to be paid in money or in indigo, cotton, silk, rice, beef, or pork, the price to be fixed by a board of six appraisers, one-half chosen by the governor and council and one-half by the popular branch of the legislature. In ease the rents were not paid in due time, the proprietors could make reasonable distress upon the goods or chattels of the owner, or, failing in this, could bring a personal action in the court of pleas. There was no provision for forfeiture of lands, except in the case of non-residents. Their lands held at the penny per acre rent were to be declared forfeited after seven years arrears, and those held at the rate of twelve pence per hundred acres after twenty-one years. The final clause declared the act unrepealable and irrevocable by any power or person whatever without the consent of the general assembly. ${ }^{2} \quad$ The other measure passed at the same time was entitled, "An Act for Remission of part of arrears of Rent and to ascertain the payment of the remainder."

1 In addition to these two there was a third form known as the pepper corn rent. The tenant delivered to the Lords Proprietors at Charleston on the 29th of September, one ear of Indian corn when demanded. Public Records, Ms., I, 154-155.

2 Statutes, II, 96-102. 
This remitted three years arrears on some lands and four years on others, and contained about the same provision for the collection of the remaining arrears as that mentioned above in the other act. ${ }^{1}$

Quiet was restored by these laws and the colonists began to direct their attention to internal politics. The land question next came up in connection with fraudulent and exorbitant grants. The provision for granting a certain amount of land for every servant or settler brought into the colony was very much abused. Four or five different grants were often made for the same servant. Large tracts of land near the settlements were secured by speculators, and the growth of the colony was retarded. The proprietors sent an instruction to the governor in December, 1699, directing that no more than five hundred acres should thereafter be granted to one person without special order from their board, and that all future grants should contain a clause of forfeiture unless settlement was made within four years. ${ }^{2}$ The abuses continued and the proprietors determined to use still more stringent efforts to check them. Accordingly, in 1710, they wrote to Governor Tynte complaining of the many exorbitant and illegal grants and providing that, for the future, no land should be sold by any agent whatsoever without an immediate order from the proprietors. All persons who desired land were compelled to apply at the proprietary board in London. ${ }^{3}$ This proved a great hard-

1 Statutes, II, 102-104.

2 Public Records, Ms., IV, 128.

${ }^{3}$ S. Car. His. Soc. Col., I, 158. 
ship to the people of the province, and complaints and petitions were so numerous that the proprietors were induced in 1713 to revoke the order and go back to the rule of 1699 allowing grants not exceeding five hundred acres to each individual. ${ }^{1}$ The abuses continued and the proprietors in 1718 revoked their concession and restored the order of $1710 .^{2}$

The proprietors were deprived of their governmental rights by the revolution of 1719 , but remained territorial lords of the Carolinas until 1729. In that year an act was passed through parliament establishing an agreement with seven of their number for the surrender of their title and interest in the provinces to the crown. ${ }^{3}$ The proprietors, in consideration of $£ 17,500$ for their rights and $£ 5000$ for arrears of quit rents, agreed to give over to the crown a seven-eighths undivided share of their "royalties, franchises, lands, tenements, and hereditaments, and premises" in Carolina, with certain exceptions, among which were included all tracts of land granted by the Lords Proprietors at any time before January 1, 1727. This left a loop-hole for much fraud, since the proprietors had been very lavish with their grants in the years following the revolution of 1719.

1 Public Records, Ms., VI, 56.

2 Ibid., VII, 159-160.

${ }^{3}$ Statutes at Large, 2 George II, chap. 34 . Lord Carteret refused to sell his interests and continued to hold a one-eighth undivided share in the territory of North Carolina and South Carolina until 1744, when he gave up all claims to the remaining parts of the province in return for a large strip of land in North Carolina bordering on Virginia. N. Car. Col. Records, IV, 655-663. 
An opinion on this act, issued February 11, 1737, by the attorney-general and the solicitor-general, Ryder and Strange, rendered fraud still more easy. They decided that land grants made in Carolina after the land office was closed in 1719 were valid, provided the Lords Proprietors had been made privy to the grants, or, after they were made, received consideration for them; also that persons holding lands under proprietary grants made before 1727 , on which surveys had actually been made, and having more than they were entitled to, might, by the act of 2 George II, chap. 34 , still retain the same and their lands be not subject to a re-survey. ${ }^{1}$

An attempt has been made in this chapter to give a brief sketch of the land system from the first settlement of the province in 1670 until its purchase by the crown in 1729 , and to trace the progress of the controversy over the two leading territorial questions, land frauds and quit rents. The following chapters will continue the discussion of these questions during the roval period and endeavor to show how they influenced the constitutional development of the province.

1 Chalmers, Colonial Opinions, 171-175. 


\section{CHAPTER II}

\section{Land Frauds}

Atrention has already been called to some of the various methods by which land was fraudulently appropriated. Though considerable abuse was made of the per capita grants for servants, the chief source of fraud was, by all means, the provision in the Fundamental Constitutions for baronial grants. It will be remembered that in each county there were to be one landgrave with four baronies and two caciques with two baronies each, and that a barony contained twelve thousand acres of land. The proprietors availed themselves of their privilege of recommending persons to the board for titles of nobility. The following list of those appointed up to 1686 is to be found among the public records:

Landgraves.

John Locke,

Sir John Yeamans,

April 4, 1671.

James Carteret,

April 5, 1671.

James Colleton,

Edmund Andros,

October 10, 1670.

Joseph West,

April 23, 1672.

Thomas Colleton,

Joseph Morton,

David Axtell,

April 24, 1674.

May 28, 1681.

July 18, 1681.

August 10, 1681. 
Sir Richard Kirle, John Price,

Caciques.

Capt. Wilkinson, Major Thomas Rowe,

Mr. John Gibbes,

Mr. Thomas Amy,

Mr. John Smith,

Mr. John Monke,
June 9, 1684.

April 30, 1686.

July 17,1681 .

February 24, 1682.

October 9, 1682.

October 12, 1682.

October 12, 1682.

February 24, 1683. ${ }^{1}$

It will readily be seen that forty-eight thousand acres to each person in the first list and twenty-four thousand to each in the second would take up a large part of the land of the province. Moreover there were many other patents of nobility issued before the fall of the proprietary government. It is not to be supposed, however, that all this land was actually surveyed and laid out for the patentees. Their grants were as a rule of a general character, merely calling for twenty-four thousand or forty-eight thousand acres of land in the province of Carolina, with the proviso that each barony should contain twelve thousand acres in one tract. The grantees made no haste to select their land and in many cases died without having taken any steps in the matter. Some of them disposed of their claims. For example, John Price, created a landgrave in 1686, sold his title with the four baronies attached to Thomas Lowndes. The result was that by 1719 nearly all of these indefinite warrants for land had passed to the heirs and assigns of the original patentees. Owing to the disturbed con-

1 Public Records, Ms., I, 12-13. See McCrady, S. Car. under Prop. Govt., 716-719. 
dition attendant on the revolution, the proprietors closed the land office in South Carolina at that time and it remained closed until 1731. ${ }^{1}$ In the meantime the colons had been growing rapidly, and the soil, especially near the coast, had very much increased in value. The holders of the old patents now began to seize all the more desirable land. Would-be settlers were at a disadvantage because they had no ancient patents and could not secure grants while the land office was closed. It was afterwards estimated that, between the years 1719 and 1731, about eight hundred thousand acres of the most valuable land in the province were thus taken up under color of patents to landgraves and eaciques. ${ }^{2}$

In March, 1730, the Board of Trade, desiring to test the validity of these grants, sent one to the king's attorney-general and solicitor-general, Yorke and Talbot, for their opinion in point of law. ${ }^{3}$ The particular grant selected was one for twenty-four thousand acres, made out to Sir Nathaniel Johnson in 1686, but not yet put into execution. An opinion was delivered in July to the effect that this and all similar grants were illegal, because they failed to designate the exact location of the land conveyed. ${ }^{4}$ On November 24, 1735, a similar opinion was delivered in the case of William Hodgson, whose patent was dated $1715 .{ }^{5}$

Robert Johnson arrived in the province, December, 1730 , with a commission as governor. Reference has

I Public Records, Iss., XXI, 339, 344.

2 Ibid., XV, 149-150.

s Ibid., XIV, 69-70.

Ibid., 246-247. Published in Chalmers, Colonial Opinions, 175-176.

${ }^{5}$ Chalmers, Colonial opinions, 178. 
already been made to the purchase by the crown of the property rights of seven of the proprietors in 1729 . Johnson was instructed to reopen the land office and to consent to a law for remitting the quit rents, which were very much in arrears. In return for this concession, the people were required to repeal Archdale's land lain' of 1696 and provide for the future payment of quit rents in proclamation money. Another article in his instructions called attention to the lavish grants made by the Lords Proprietors and recommended the passage of a law compelling all grantees to at once settle and cultivate their lands. The governor was warned not to grant more than fifty acres to a man for each member of his household, including servants and slaves. ${ }^{1}$

A bill for the remission of arrears of quit rents, for the registering of patents, grants, and title deeds, for the repeal of the statute of 1696 , and for various other purposes mentioned therein was passed August 20, 1731. It provided that patents or grants, except those for town lots, should be registered in the auditor-general's office within eighteen months on penalty of forfeiture. The most important section of the law, perhaps, was that which guaranteed the validity of all grants made by the Lords Proprietors, notwithstanding any defects in describing the land, provided some part of it had actually been surveyed by a sworn surveyor. The term sworn surveyor was held to include the surveyor-general appointed by the proprietor's, together with his deputies. Practically all the grants made to landgraves and caciques were thus confirmed, for, as

1 Public Records, Ms., XIV, 156-157, 172-173. 
already stated, a large part of the best land in the province was surveyed during the years 1720 to 1730 inclusive. But, as if this were not sufficient license for fraud, it was further provided that titles would be complete, if surveys were made at any time within two years after the arrival of a surveyor-general in the province. $^{1}$ The bill was sent to England for the approbation of the ling, and there met with considerable opposition.

In 1731, Mr. James St. John came over with a commission from His Majesty as surveyor-general of lands. ${ }^{2}$ Filled with a zeal to maintain the rights of the crown as well as the rights of the subject, he began at once to oppose the schemes of the land speculators. He was ably seconded in his efforts by Benjamin Whitaker, then deputy surveyor-general, and by several other leading men of the province.

In a long communication to the Board of Trade, received in September, 1732, St. John gave a history of the troubles in South Carolina and his reasons for objecting to the quit rent act. He first called attention to the numerous indefinite grants made before the sear 1700 and to the opinion in the Sir Nathaniel Johnson case which declared them all void. In spite of this opinion, he said, the quit rent act had guaranteed the validity of such patents. A confirmation of the act would result in several inconveniences. The first objection, in regard to the quit rents, will be treated in the next chapter. The second was that the grants for

I Statutes, III, 289-304.

${ }^{2}$ Public Records, Ms., $\mathrm{Ar}^{*}, 41-42$. 
the lands thus taken up had never been returned nor recorded in any public office, whereby the king could know exactly what land each patentee held, and it had been possible for the grantees to take up an indefinite amount under color of their patents. Some had taken timbered land, and, after using all the timber, had left it and seized other tracts. In the third place, the patentees and speculators had acquired all the best land on navigable rivers, and newcomers were obliged to take less desirable lands or purchase from them at an exorbitant price. Many settlers, he declared, had actually left the province on this account. ${ }^{1}$

Enclosed with St. John's letter was a report on the quit rent act made by Mr. Whitaker while he was attorney-general of the province. Whitaker, who was a man of considerable legal training, proceeded to show that the landgrave and cacique patents were void, not only because they were indefinite as to time and place, as set forth in the Johnson case, but also because, for the most part, the original grantees had died before ever their lands were surveyed. According to the principles of the feudal law their heirs could not inherit, since they had died without being seized of any of the land. He questioned the opinion in the case of Rusco versus French, which had just been delivered in the chancery court at Charleston. The opinion was that a landgrave patent of 1698 , indefinite as to time and place and under which no lands were ever taken possession of during the lifetime of the original grantee, was nevertheless valid and the titles of the present holders good

1 Public Records, JIs., XV, 149-159. 
in law. ${ }^{1}$ Whitaker also pointed out the fallacy of the argument that these grants must be confirmed in order to protect innocent purchasers by showing that the poorer settler's would be benefited by throwing open such vast tracts for settlement. ${ }^{2}$

In another document sent over at the same time, St. John made other observations. He cited the clause in the quit rent act which required all grants and land titles to be registered within eighteen months and stated that there was then a bill before the assembly to extend the time, allowing it to be done at any time within eighteen months after the quit rent act had been approved by the king. Thus, said he, they were threatening to deprive the king of his rents unless he would consent to an act guaranteeing exorbitant land grants. Furthermore, the council had recently passed a resolution "that all surveys made of His Majesty's lands in this province without a warrant from His Excellency the Governor and a deputation from James St. John, Esq., His Majesty's Surveyor-General, be void reserving such as may be valid by the act made in this province for the Remission of the Arrears of Quit Rents passed 20th of August." By this reservation the old patentees regarded themselves as absolved from the necessity of securing a warrant from the governor and a deputation from the surveror-general, and had taken up lands in whatever manner and quantity they thought fit and without any regularity, since no surveys were required to be returned to the office of the

See Blackstone, Commentaries, Book II, Chaps. XIV and XX.

2 Public Records, Is., XV, 170-185. 
surveyor-general. Another abuse had grown out of the clause in the governor's instructions which allowed fifty acres of land to be granted for each servant. The object of this had been to attract new settlers and, at the same time, to prevent them from securing more land than they could cultivate. It had, however, been taken advantage of by old settlers, who were already land-poor, and some six hundred thousand acres had thus been appropriated. The result of it all was that there were not as many as one thousand acres within one hundred miles of Charleston or within twenty miles of a river or navigable creek, which were not already taken possession of. 1

Governor Johnson and many of the members of the council and assembly were, according to St. John and Whitaker, among the largest holders of these old patents and hence rere especially anxious to have the quit rent act ratified in England. Hearing that it was about to be disallowed because of St. John's objections, ${ }^{2}$ they proceeded to annoy him in every way they could. First, they accused him of taking exorbitant fees for his services and passed an act fixing the fee for surveying at four pence currency per acre and requiring an equal division of this with the deputy. ${ }^{3}$ Previous surveyors-general had always regulated this matter by private contract with their deputies. Secondly, Governor Johnson had been instructed to lay out eleven townships in the province for the benefit of new set-

1 Public Records, Ms., XV, 160-169.

2 Ibid., 230; S. Car. Gasette, October 7, 1732.

${ }^{3}$ Statutes, III, 343-347. 
tlers. ${ }^{1}$ St. John was authorized to do the surveying at the rate of one penny per acre, but he had barely begun when he was interrupted by a resolution of the assembly to postpone work. The reasons alleged for their action were that it was uncertain when a sufficient number of people would arrive to settle the townships, that the surveyor-general's demand of one penny per acre was exorbitant, and, finally, that if the survey were made now, the marks would be so perishable that it would have to be done again within three years. St. John, in a report to the Board of Trade, answered these arguments and stated that they should have asked him whether he would do the work for less. Instead of that, the governor and council went ahead and employed some members of the council to do the surveying, and thus deprived him of the rightful profits of his office. Furthermore, said he, the fee bill required him always to survey land when called upon and iorbade his charging any more than the legal rate, under penalty of a fine of two hundred pounds proclamation money for each offense. This was designed purely to annoy him, for, if he were sent for to survey fifty acres of land one hundred miles from Charleston, he would receive only a few shillings, while his expenses would be many times as great. ${ }^{2}$

The wrath of the land speculators was not restricted to St. John and Whitaker, but fell upon all who opposed their schemes. Early in 1733, one William Trewin came to South Carolina with letters of recommendation

1 Public Records, Ms., XIV, 174-175.

2Itid., 160-169, 201-203. 
from the Lords of Trade and the Duke of Newcastle. Being treated very coldly by Governor Johnson, he allied himself with the St. John-Thitaker faction. In a latter to the Board of Trade, under date of May 12, 1733, he stated their side of the question. ${ }^{1}$ To begin with, he said that the governor and a few other men had acquired large tracts of land under color of the old patents from the Lords Proprietors. The people on the frontiers about Port Royal had been driven from their homes by the Indians, and on returning, found all their lands in the possession of the speculators. A number of men, among whom was a certain Dr. Thomas Cooper, determined to survey some land on these tracts in order to get a case in court and test the validity of the titles. The speculators, instead of submitting their titles to a judicial decision, applied to the commons house of assembly, who ordered Cooper into the custody of their messenger and kept him prisoner for five weeks. Soon after his apprehension, Cooper applied to two justices of the peace for a writ of habeas corpus. It was granted and delivered to the messenger, but he refused to obey the writ, and the house indemnified him. A second writ was issued by Mr. Middleton of the council and a Mr. Somerville, and a third by Robert Wright, the chief justice, both of which were likewise unheeded. He then petitioned the governor and council and also the governor separately to issue writs. These petitions were not only disregarded, but two merchants who waited on the governor with the petition to him

${ }_{1}$ Public Records, Ms., XVI, 112-119. The following account is taken largely from this letter. 
were taken into custody. They secured their release only after they had paid heavy fees and asked pardon for their conduct. Several merchants and lawyers were likewise committed to prison by the lower house for carrying petitions to members of the house who were justices of the peace, and all were required to pay extortionate fees before securing their discharge. Dr. Cooper finally regained his liberty after an imprisonment of sereral weeks. In the meantime the people of Port Royal had chosen him to be one of their representatives in the assembly.

The commons house became enraged at the chief justice for issuing writs to their messenger, presented accusations against him before the council, and had the charges published. The main charge was that he had riolated the privileges of the house in issuing writs to their messenger. An act was passed, May 4, 1733, entitled, "An Act for the prevention of suits and disturbances to His Majesty's Judges and Magistrates in this province, on account of the Habeas Corpus Act." This provided that no public officer should be liable to any suit or penalty for refusing to issue or to obey a writ of habeas corpus petitioned for by any one committed to prison by either house of the legislature for violation of its privileges." This was of course to indemnify the messenger for his conduct. Chief Justice

1 There was no public prison in the province at this time. The provost marshal took charge of ordinary prisoners and kept them at his own house or in some other place prepared by himself. The messenger of the assembly took charge of persons committed for contempt of the house. In either case they receired fees for their trouble and expense.

2 Statutes, III, 347-348. 
Wright very ably opposed the act in the council and, in the defence of the habeas corpus act, declared it to be "the strongest barrier that the wisdom of our ancestors could devise to preserve the liberties of the subject and secure the people from arbitrary violence and oppression." Mr. Francis Yonge, another member of the council, made a long speech in reply in which he attempted to show by the practice of the House of Commons in England that the commons house had a right to arrest for contempt and that a writ of habeas corpus was not an effective remedy. He cited the case of Mamwaring vs. Sacheverel and various others to sustain his point. ${ }^{2}$ The council published a resolution to the effect that the lower house possessed all the rights and privileges of the English House of Commons and that Yonge's speech rather than Wright's represented the sense of their body. ${ }^{3}$ The lower house now attacked the chief justice in the most effective way possible to them. On May 30 they resolved that they would make no provision for his salary in the estimates for the current year. ${ }^{4}$ Wright, however, continued his opposition to the bill after it was sent to England and it was largely through his representations that it was finally disallowed. ${ }^{5}$ Governor Johnson and the council were quite as angry with the chief justice as were the members of the lower house. But they were wise

1 Public Records, Ms., XVI, 186-188.

2 S. Car. Gazette, No. 66, April 21, 1733.

${ }^{3}$ Ibid., No. 67, April 28, 1733.

${ }^{4}$ Public Records, Extra, 3Is., I, Part II, 1085-1086; S. Car. Gazette, No. 72, June 2, 1733.

${ }^{5}$ Statutes, III, 349; Public Records, Hs., XVI, 203-212, 248-257. 
enough to see that it was not good policy to recognize the right of the assembly to withhold public salaries. They saw it all the plainer because at that very time President Middleton of the council was trying to recover the salary due him for the period he had served as acting governor. Middleton had aroused the wrath of the commons by opposing their paper money schemes. The members of the council sympathized with his financial views. Governor Johnson realized, too, that his own influence in the government depended largely upon the issue of the Middleton case. The dispute dragged on for several years. Middleton received a part of the amount due him, but the assembly obstinately refused to pay the remainder. ${ }^{1}$ Neither would they make any provision for the chief justice until after a special order from the crown had been received. Even then there was some delay and he was finally compelled to satisfy himself with one-third the amount due him. A warrant from the crown, received in 1735, provided that in the future his salary should be paid from the quit rent fund. In this way the judiciary became independent, or rather it became dependent upon the crown instead of upon the commons house of assembly.2

I Nicholson received $\mathfrak{3 0 0 0}$ currency per annum. In his absence this amount should have been divided equally between him and Middleton. For the three and a half years in dispute Middleton should have received $£ 5250$. Instead he was paid only $£ 3000$. Half of this, according to his statement, he had to give to the governor.

${ }_{2}^{2}$ Public Records, Extra, M1s., II, 138-141, 151, 206; Com. House Journals, Us., IX, 5S-59, 133, 219-220, 535-536, 651-656, 707, X, S, 11 ; Public Records, Ms., XVII, 257-259, 319-321; Statutes, III, 43S-44S. See pp. 295-302. 
Meanwhile the quit rent act was being considered in England. The Board of Trade referred it to the Treasury Board as a measure affecting the revenues. After considering the arguments of St. John, Whitaker, and the attorney-general and solicitor-general against the bill, and those of Governor Johnson, and Fury, the colonial agent, in its faror, the Treasury Board reported, October 6,1732 , that the measure was unfit for His Majesty's approbation. The Lords of Trade then drew up an address to the King telling him of the opinion of the Treasury Board and of their own concurrence in the same, and begging him to disallow the act. $^{1}$

As soon as news of this was received in the province there was a clamor for revenge upon those who had been instrumental in securing the adverse report. St. John was arrested on some frivolous pretense and kept in prison until his release was ordered by the Board of Trade. ${ }^{2}$ The governor tried to defeat Whitaker in his candidacy for the assembly from Port Royal and injured him in his property rights by stopping a land grant which Whitaker alleges was regular in every way. ${ }^{3}$ James Graeme, Job Rothmaller, and William Trewin were elected to the assembly from Port Royal, but the house refused to seat them. Various pretexts were advanced. For example, Trewin was rejected on the ground that his Christian name was not mentioned in the writ, and, as the assembly naïvely ex-

1 Public Records, Ms., XV, 239-246.

${ }^{2}$ Ibid., XVI, 137-139, 145-146, XXII, 443.

sIbid., XXII, 445-447. 
pressed it, "it was wholly uncertain what Trewin is meant by the said return."' The real reason, of course, in every case was that these men had opposed the schemes of the land speculators.

Strange to say, the king did not repeal the law, in spite of the adverse reports of the administrative boards, for as late as 1744 mention is made of it as still in force. ${ }^{2}$ A careful search of the records has failed to disclose any further reference to it after that date. The land speculators thus scored a victory.

This massing of land in great tracts had some important results: its immediate effect was to retard very much the growth of the colony; of vastly more importance, however, was its influence in building up that wealthy slave-holding aristocracy, which was for so long a time the conspicuous feature of South Carolina life.

Seeing that he was not properly supported by the authorities at home, Mr. St. John relaxed his efforts. Nothing further was done to check the abuses until 1739, when Henry McCulloh was appointed "Commissioner for Supervising, Inspecting, and Controlling His Majesty's Revenues and Grants of Lands," with instructions to go to North Carolina and South Carolina, and carefully look into the abuses there. ${ }^{3} \quad$ The special abuses were the granting of township lands to those who had no intention of settling upon them ${ }^{*}$ and the granting of large tracts of other land in direct violation of

1 Public Records, Extra, Ms., II., 5-6, 10, 14, 27-28, 59-63.

2 Public Rccords, Ms., XXI, 348.

${ }^{3}$ Ibid., XX, 143-144, 445.

'S. Car. Gazette, No. 165, March 27, 1737. 
the royal order to preserve the proportion of fifty acres for each member of a man's household. ${ }^{1}$ The fifteenth and sixteenth articles of his instructions prescribed in detail the method to be observed in the future for the granting of lands. The applicant had first to prove his rights before the governor and council when at least four members of the council were present who had no concern or interest in the land petitioned for. If the petition was granted, a warrant was drawn up and signed by the governor and council and made returnable by the surveyor within twelve months from the date of issue. The land desired was to be particularly described in the warrant and a docket of it was entered in the auditor's office. On the return of the warrant, the grant was made out containing the terms and conditions on which the warrant was issued and the lands surveyed. The grant was then to be registered in the secretary's office and a docket thereof in the auditor's office within six months. Copies of all these entries were to be sent to England within twelve months, either to the Treasury Board or to the Board of Trade. ${ }^{2}$ This careful check and balance system, if carried out, would have rendered fraud almost impossible.

On arriving in the province, if his own account may be trusted, McCulloh met with opposition from the council and the crown officers, while the commons house showed a disposition to do their duty in framing a rent roll bill and settling the other disorders of the province. They were even then, said he, inquiring into the griev-

1 Public Records, $\mathrm{Ms}$, $\mathrm{XX}, 126-128,148$.

2 Ibid., 148-149. 
ances of the settlers in Williamsburg township, who had been defrauded of their lands by some members of the council and other prominent men obtaining township grants from Governor Johnson and LieutenantGovernor Broughton in direct violation of the royal instructions. ${ }^{-1}$

Furthermore, after the Stono insurrection in $1739,^{2}$ the commons house passed an act obliging all large land owners to furnish a certain number of white men for militia duty in proportion to the amount of land which they possessed. This was sent to the council and disregarded by them, notwithstanding repeated requests of the house that they either pass it or state their objections. McCulloh gives as the reason for this conduct the fact that the members of the council did not wish an examination made into the amount of lands which they held, nor did they wish to be put to the expense of settling them. ${ }^{3}$

MeCulloh's attempt to carry into effect the method of passing land grants prescribed in his fifteenth and sixteenth instructions likewise failed. He gave a copy of the instructions to James St. John, who was still surveyor-general of the lands, and asked him to abide by them. On April 2, 1741, a warrant was issued by the secretary, in pursuance of an order of the governor in council, and offered to St. John to make out his precept thereon. He refused to comply and went to

1 Public Records, $1 / s ., \mathrm{XX}, 420-421$.

2 For an account of this see MeCrady, S. Car. under Royal Govt., $185-186$.

${ }^{3}$ Com. House Journals, Hs., XII, 126-127, 155-156, 329; Council Journals, Is., VII, 320; Public Rccords, Is., XX, 421-425. 
McCulloh for advice. McCulloh told him to go to the governor and council, and lay before them a copy of the instructions he had received. If the governor still persisted in ordering him to make out the precept, he was to do so. McCulloh stated as his reason for giving this advice the fact that there was a law of the province which required the surveyor-general, under a severe penalty, to obey all orders of the governor and council. St. John did as he was directed, and the governor renewed his order to issue the precept. The council then drew up resolutions censuring McCulloh for his conduct. $^{1}$

The opposition proving too strong, McCulloh soon gave up the struggle and went to North Carolina, where he seems to have acquired a large amount of land for himself. ${ }^{2}$ He was a prolific writer and the public records of this period are filled with his complaints and suggested remedies. One of the latter was that he should be given the power to stop the salaries of all disobedient crown officials; ${ }^{3}$ another, that a court of exchequer should be established for the trial of such officials. $^{4}$

During the remainder of the colonial period there was little systematic effort made to check fraudulent land grants, but there was less opportunity for fraud, since the best lands of the province had already passed out of the hands of the crown. The instructions to the dif-

1 Public Records, Ms., XX, 426-429.

2 N. Car. Col. Records, V, 621-622.

- Public Records, Hs., XX, $\$ \neq 0$.

Ibid., XXI, 126. 
ferent governors always warned them to guard against fraud and extravagance.

On April 7, 1773, owing to the excited condition of the colony, the king in council ordered the closing of the land office in South Carolina. ${ }^{1}$ As soon as news of this was received in Charleston, Lieutenant-Governor Bull notified the officials of this office and published notices in the Gazette. On June 14, he wrote to the Earl of Dartmouth, secretary of state for the colonies, telling him that the order had caused much suffering, since there were one hundred and twenty-six grants waiting to be signed by the governor on the next day, seven hundred and three plats of survey in the surveyor's office awaiting the issue of grants, and one thousand eight hundred and seventy-six warrants then in the hands of deputy surveyors who were actually surveying the lands. ${ }^{2}$ The king sent over an order early in 1774 for the completion of these grants. ${ }^{3}$

A new system of granting out the remainder of the crown lands was adopted by the home government and instructions were sent out to the governor in February, 1774. The governor, lieutenant-governor, surveyorgeneral of lands for the southern district of North America, the secretary, the surveyor-general of lands in the province, and the receiver-general of the quit rents, or any three of them, were to see that all the land in the province fit for settlement and not yet granted was at once surveyed and divided into lots of

1 Public Records, Ms., XXXIII, 272.

2 Ibid., $272-274$.

I Ibid., XXXIV, 41-42. 
not less than one hundred nor more than one thousand acres, the size to be determined by the surveyor-general according to the nature and situation thereof. After due notice had been given, these lots were to be put up for sale to the highest bidder, a minimum price for each tract to be fixed by the governor, council, and board mentioned above, and a quit rent of one-half penny sterling per acre reserved on all of it. On paying the receiver or his deputy the purchaser would receive a bill of sale to be taken to the governor and exchanged for a grant in fee simple. Full reports were to be made regularly to one of His Majesty's principal secretaries of state. ' The outbreak of hostilities probably prevented the carrying out of this scheme.

I Council Journals, Ms., XXXVIII, 23-28. 


\section{CHAPTER III}

\section{Quit Rents}

Ax account has already been given of the quit rent controversy up to the passage of Archdale's law in 1696. ${ }^{1}$ For several years there was no trouble in regard to the matter. The rents seem to have been paid with a fair degree of regularity until about 1709 . From then until 1719, collection was more difficult and from 1719 to 1731 impossible. The proprietor's made numerous complaints of the difficulty of collection, and in March, 1719, the general assembly passed a statute to render the work easier. Thị act required all land owners to show to the receiver-general of the quit rents their grants and the terms on which they held, on penalty of $£ 20$ current money. They were also to show their last rent receipts or state on oath the time of their last payment, and arrears were made recoverable by action for debt in the court of common pleas. Rents were to be paid in proclamation money or else in rice, pitch, or tar at certain prices fixed in the act. After thus dutifully providing for the collection of the rents, the people's representatives went on to dispose of the proceeds. The ninth section of the act stated that the Lords Proprietors had, on November 3, 1716, sent out instructions authorizing the use for public purposes

1 See Chapter I of this section. 
of all rent due up to May, 1718, certain specified sums being first deducted; that they had since revoked this gift, but, as the people were now providing for the collection of the rents, they hoped that the disputes would cease, and enacted that rents up to the end of 1723, after deducting certain salaries, should be used to build a state house and a gaol. The final clause provided that the act was not to be put in force until approved by the proprietors. It is perhaps needless to add that they promptly rejected it."

In 1728 , the proprietors sent a memorial to the privy council asking that, in case they advised the king to purchase the provinee, they should recommend the payment of $£ 5,000$ additional for arrears of rent. Along with the memorial was an estimate of the amount due them. From 1719 to 1728 the arrears in both North and South Carolina were placed at $£ 7,200$. This, together with the fines and fees and one-tenth of the mines and whale fisheries amounted in all to £9,500. They also stated that for the ten years previous to 1719 there had been no accounts between the proprietors and their receivers, a settlement of which would show at least $£ 6,000$ more due them. ${ }^{2} \quad$ By the act of parliament passed in 1729 for establishing an agreement with seven of the Lords Proprietors, their request was granted and they were paid $£ 5,000$ for the arrears of rent. ${ }^{3}$

The province had now come entirely under the crown. On June 30,1730, the Lords of Trade in an address to the king suggested that the arrear's should be remitted

1 Statutes, III, 44-49.

2 Public Records, IIs., XIII, 8-11.

3 Statutes at Large, 2 George II, chapter 34. 
to the colonists under certain conditions. First, they should repeal the land law of 1696 , because the provision for payment in produce at a valuation fixed by a board of appraisers, three nominated by the governor and council and three by the assembly, tended to lessen the value of the rents. Secondly, all possessors of land should be required to register their grants together with the amount of quit rents reserved thereon. And finally, all rents for the future were to be paid in proclamation money. ${ }^{1}$ Instructions were made out to Governor Johnson empowering him to consent to an act embodying these terms. ${ }^{2}$ Such a measure was passed August 20, 1731. Its main provisions have already been considered in another connection. It is sufficient here to say that seven-eighths of all arrears of rent up to the 25th of the previous March were remitted, and provision made for future payments in proclamation money on the 25 th of March of each year. In case a man failed to pay within three months after March 25, officers were empowered to seize and sell his goods. If he were delinquent for five years and had no goods to be levied upon, his land was to be forfeited, saving the rights of minors and femes coverts, who were to have three years in which to settle after coming of age or removal of coverture. Persons living in Granville county were to pay at Port Royal, those in Craven county at Winyaw, and those in Berkeley and Colleton counties at Charleston. ${ }^{3}$

${ }^{1}$ Public Records, Ms., XIV, 141-143.

2 Ibid., 156-157.

Statutes, III, 289-304. It is possible that feme covert in this law should read feme sole. I take it that the exemption would extend to unmarried rather than to married women. 
The long and successful struggle on the part of the land speculators to prevent the king's disallowing this act has already been discussed.

In spite of the careful provisions in the law for the collection of rents it seems that they were by no means regularly paid. An advertisement, inserted in the Gazette of July 13, 1734, by the receiver-general of the quit rents, stated that many had not paid for two years and some not at all. He warned delinquents to settle at once and threatened to levy on their goods. ${ }^{\text {" These }}$ notices were frequently published, hence we must conclude that the people were no more willing to pay the king than they had been to pay the proprietors.

Attention has already been called to the appointment in 1739 of Henry McCulloh as "Commissioner for Supervising, Inspecting, and Controlling His Majesty's Revenues and Grants of Lands." His duties were to put a stop to land frauds and to secure a better collection of the quit rents. Having seen how he failed in his first duty, we will now consider briefly his attempts to perform the second.

Immediately on his arrival in the province, $\mathrm{McCul}$ loh wrote a letter to the speaker of the assembly telling of his anxiety to put an end to the disputes over quit rents and land grants, and asking the speaker to explain his mission to the assembly. ${ }^{2}$ At the same time he issued a circular letter to the freeholders of the province assuring them of his good intentions and begging them to co-operate in securing a final settlement of the

${ }^{1}$ S. Car. Gasctte, No. 24, July 13, 1734.

${ }^{2}$ Public Records, Ms., XX, 442-445. 
troubles. Notice was given to all who had not registered their titles in the office of the auditor-general to do so at once. He also warned them that land would be declared forfeited after five years non-payment. ${ }^{1}$

MeCulloh's next step was to hold a conference with Lieutenant-Governor Bull and submit to him certain proposals for a quit rent bill. ${ }^{2}$ Bull sent them to the lower house with a message urging immediate action. ${ }^{3}$ There were fourteen heads in the proposals. The first required the registration of all mesne conveyances in the auditor's office within eighteen months under penalty of forfeiture, and the ninth and tenth required all persons holding lands by any title whatsoever, not within the outlines of townships, to settle them within four years with one white man for every one thousand acres of land, and, within townships, two white men per thousand acres. ${ }^{4}$ The commons house in committee of the whole agreed to these propositions in the main. In section one, however, they suggested a milder penalty than forfeiture, namely, the payment of a double or treble rent; and in section nine they excepted proprietary patents and provided that the owners of the land and their sons over sixteen should be counted as part of the required number of adult white settlers. They also agreed that a clause should be introduced to confirm every part of the quit rent law of 1731 not altered by this act. ${ }^{5}$ On May 26, 1741, the lower house adopted

1 Public Records, Ms., XX, 445-454.

2 Governor Glen had not ret arrived in the province.

3 Com. House Journals, Ms., XIV, 345-346.

4 Ibid., 346-353.

5 Ibid., XV, 8-12. 
this report with some slight amendments. ${ }^{1}$ The lieutenant-governor sent down a message on the 27 th, again urging immediate action. ${ }^{2}$ In reply the house said that they would have to consult their constituents before finally passing such a law." An act entitled, "A bill to enable His Majesty's officers of the revenue to make out and fix a more perfect and exact roll or particular of His Majesty's quit rents ; and to carry on and continue the same for the future...," passed the house, June 30. On the same day an order was adopted that, as soon as it came from the council, it should be printed and a copy given to each member to show to his constituents. ${ }^{4}$ The council returned it on July $1 .^{5}$ MeCulloh, in a report to the Board of Trade, says that the council opposed him all the time and states incorrectly that it was they who ordered the bill published and distributed among the planters to see what effect it would have. ${ }^{6}$ As a matter of fact, this was done by the assembly. The people, continues MeCulloh, were very much excited over the prospect of being compelled to pay their rents and urged upon their representatives the necessity of crippling the act as much as possible. ${ }^{7}$ The house was now ready to drop the bill if only some excuse could be found. This came in the presentments of the Charleston grand jury, made at the October session of

1 Com. House Journals, Ms., XV, 21-25.

${ }^{2}$ Council Journals, 1Is., VII, 409.

s Ibid., 410.

4Com. House Journals, Us., XV, 92-93.

${ }^{5}$ Council Journals, Hs., VII, 420.

${ }^{6}$ Public Records, IIs., XX, 418.

T Ibid., 418-419. 
1741. These presentments were sent to the house by the lieutenant-governor and read there on December 3, 1741. The fifth clause presented the rent roll bill as containing "diver's clauses of a dangerous nature to the property of His Majesty's Subjects of this Province." The presentments were referred to a special committee of seven members, which reported, on December 8, that the fifth clause was still under the consideration of the house. ${ }^{1}$ Nothing more is heard of the act until March 1,1742 , when the council sent down a message stating that they had passed the rent roll bill and sent it to the lower house as far back as the previous first of July. They called attention to its importance and urged the house to act upon it at once. The assembly replied that it was now too late in the session to further consider the matter and that they thought it better to postpone it altogether until the arrival of the new governor, who was daily expected. ${ }^{2}$

McCulloh was not the man to give up the struggle merely because he had met with this rebuff. He continued to quarrel with the various crown officials, to give his advice where it was not wanted, and to make innumerable complaints to the home government. Soon after his arrival in the province he asked Mr. Hammerton, secretary of the province and receiver-general of the quit rents, to make out a statement of the arrears of rent due to March 25, 1740, and a copy of the receipts as entered in his books; also that, as secretary of the province, he should make out a list of all warrants and

${ }^{1}$ Com. House Journals, $\mathbb{M}$ s., XVI, 86-87, 118-124.

${ }^{2}$ Ibid., XVII, 263-264, 267-268. 
grants issued since 1730. Hammerton refused to do this and McCulloh wrote to the Board of Trade charging him with being short in his accounts to the crown about $£ 1,500$ sterling. ${ }^{1}$ Hammerton explained his refusal to grant the request on the ground that it would entail an immense amount of work upon his clerks, who were already occupied with current business. He asked $\mathrm{McCulloh}$ to send over his clerk to do the work, assuring him that he would have every courtesy extended him. This was refused, and Hammerton declared that he could not furnish the lists. ${ }^{2}$ These charges seem to have had some effect, however, for in August, 1742, Hammerton was superseded as receiver-general of the quit rents by George Saxby. ${ }^{3}$

McCulloh's propensity to meddle in every question that came up often got him into trouble. Mr. Manigault, the public treasurer of the province, resigned early in 1743. McCulloh thought that it would be a good plan to unite the offices of treasurer and receiver of the quit rents. Accordingly, he wrote a letter to the lieutenant-governor in which he said, "I think it my duty to remind Your Honor of His Majesty's pleasure signified to you in relation to the appointment of a Provincial Treasurer.' Bull laid the letter before the council and they asked him what were the instructions referred to by McCulloh. He replied that he had none. The council then expressed the opinion that McCulloh's conduct in asserting what was His Majesty's pleasure

1 Public Records, Ms., XX, 433-434.

2 Council Journals, Ms., X, 113-120.

${ }^{3}$ S. Car. Gazette, No. 437 , August 9, 1742. 
was unbecoming, and that, even if the king had signified his wish to the governor in regard to the office, it was none of McCulloh's business to point out the governor's duties to him. Bull sent a copy of this minute of the council to McCulloh and told him that he had no right to remind the governor of his instructions or dictate to him in regard to appointments, and that when he wanted advice he would go to the gentlemen appointed for that purpose, namely, His Majesty's council. McCulloh did not seem to know that the treasurer was elected by statute and not appointed by the governor at all. ${ }^{1}$

Another attempt to secure the passage of a rent roll bill was made in 1743. On March 2, Lieutenant-Governor Bull sent a message to the assembly together with a memorial from McCulloh setting forth the disadvantages attending the collection of rents because those who held land directly from the crown were not required to enter memorials with the deputy auditor when they transferred it by mesne conveyances. Thus the receiver could not collect the rent because he could not tell who owned the land. He suggested that the legislature should pass an act requiring all landholders to give to the inquirers and collectors of the public tax an account of the exact quantity of land they held either in their own right or in the name of others; also an account of their grants, whether they were from the king or the proprietors, dates, and rents due thereon. The house referred this memorial to a committee of eight, of which Dr. Bull was ${ }^{1}$ Pullic Rccords, Ms., XXI, 142-148. 
chairman. ${ }^{1}$ The report, made on March 8, agreed that the rent roll was defective, owing to the fact that mesne conveyances had not been recorded in the auditor's office. As the time for collecting the annual tax was now too short to carry out McCulloh's scheme, they suggested that a bill be brought in requiring all holders of land granted since the property of the province had been rested in the crown, whether they held by original grant, mesne conveyance, descent, or otherwise, to enter memorials in the auditor's office on oath within a certain time. They also recommended that persons entering such memorials when they transferred property and paying all rent due up to the time of transfer should be exempted from paying rent on said property any longer. The lrouse took this report under consideration and adopted it with some amendments. The first paragraph was changed so as to exempt all who held by immediate grant from the crown. It was also amended in a favorable direction by the addition of a provision that all persons, whether original grantees or purchasers from them, who had sold land to non-residents, should register in the auditor's office memorials of the mesne conveyances by which they had sold such land. They likewise agreed with the last paragraph of the report providing for the introduction of a bill, and the same committee was ordered to draft one. ${ }^{2}$ No further action was taken until February 25, 1744, when the house ordered the committee to bring in their bill. It was accordingly presented on March 3,

${ }^{1}$ Com. House Journals, Ifs., XVIII, 460-463.

2 Ibid., 515-518, 524-526. 
passed through both houses on three separate readings, and finally became a law, May 29, 1744, under the title, "An Act to remedy some defects in His Majesty's Rent Roll...."' The preamble stated that the provisions already made by law for ascertaining the quit rents and making up a rent roll had proved inadequate. The first section enacted that all persons claiming land under titles granted by the king since the province had been vested in the crown should, within eighteen months after the royal approval of the act, deliver to the auditor-general memorials of their mesne conveyances, claims, and titles, with an accurate description of the land and the rents reserved thereon. Sections two, three, and four provided that all transfers of land should be registered within eighteen months, with the usual extension of time to minors and femes coverts. Section five allowed persons disposing of their land to settled residents of the province and giving assurance that the new purchaser would pay the quit rent for five years to be themselves discharged from the further payment of rent, provided that memorials of the sale were duly entered and all the arrears paid up to the time of entering the memorial. Section six stated that large quantities of land had been monopolized by a few persons and not cultivated as required by the instructions to Governor Johnson, and that many owners were willing to surrender their land so that it could be settled by poor Protestant settlers, but were unable to do so. Therefore it was enacted that the owners of such land, on paying the quit rents up to date,

${ }^{1}$ Com. House Journals, Ms., XIX, 241-242, 249, 345-346; Statutes, III, 633-637. 
might surrender to the governor and council all the land called for in their grants and be forever freed from the payment of quit rents. Section seven provided that no land should be thus surrendered whereon waste had been committed by making pitch, tar, or turpentine. By section eight relief was given to persons deceived by frauds of surveyors and thus charged with rent for land which they did not possess. The final section provided that the act should not go into operation until approved by His Majesty, thus differing from the quit rent law of 1731 , which was still in force though it had never received the approbation of the king.

In a report to the Board of Trade, under date of June 25, 1744, Chief Justice Whitaker presented some observations on this bill. His first was in regard to what were known as family rights. When the land office was opened in 1731, many people applied for land warrants in proportion to the number of people in their families at the rate of fifty acres for each person. These warrants were so much trafficked in that the revenue officers could not tell who owned the lands or how to collect the rents. He went on to tell of McCulloh's proposals and then of the plan finally adopted by the legislature and expressed in the act under consideration. His second observation was in regard to the fifth section. This, he said, was intended to prevent the conveyance of land to persons unable to pay the rent. True, the part releasing the original holder from the payment of rent five years after sale might be an encroachment on the royal prerogative, but he thought that it would 
do much good by securing a more perfect rent roll. Observations three, four, and five treated of that part of the sixth section of the act which allowed the governor and council to resume lands not properly cultivated and to receive those surrendered by their owners. Whitaker called attention to the importance of this provision and said that the assembly would not pass an act with such a clause except on the condition that it was not to go into effect until approved by the king. Observation six called attention to a defect in the act in that it applied only to land granted since the king's purchase, whereas the rent rolls could not be completed without an account of the land held under proprietary grants. The report then gave some figures for the year 1742 to show how difficult it was to collect the rents. In that year there were held under grants from the proprietors $1,453,875$ acres. The rent had been paid on 500,000 acres and there were left 953,875 acres still unaccounted for. 1,885,254 acres were held under royal grants, of which the rent had been paid on 430,000 , leaving 1,455,254 unaccounted for. ${ }^{1}$

Writing to the secretary of the Board of Trade, January 16, 1745, McCulloh stated his objections to the act. Instead of improving the revenue from the quit rents, he declared that it would simply open the door for new frauds; that the planters had long wanted a method of disposing of their poor lands and being relieved of the quit rents; that before he came they thought that they could do this by selling their land to transients, but he had tanght them better. Now they

I Public Records, Ms., XXI, 338-358. 
wanted legal sanction for their conduct and it was given them by the fifth section of this act. The assembly had tried to get a clause into the bill requiring holders of township lands to cultivate them on penalty of forfeiture, but the council had induced them to drop it on the third reading. Finally, he called attention to the clause which allowed owners to surrender their land to the governor and council and be released from the payment of rent, and said that this was intended to give the land speculators in the council a chance to dispose of those township lands not likely to prove profitable. ${ }^{1}$

A month later, McCulloh again wrote complaining that the Treasury Board had given him no support and that the Board of Trade had not laid his troubles before the king. He said that he had been insulted in the grossest manner and deprived of all means of supporting himself, and that Governors Glen and Johnston and several other gentlemen both in North Carolina and South Carolina had continually misrepresented him. ${ }^{2}$ He closed with a series of charges against George Saxby, the new receiver-general of the quit rents. Saxby had exacted sums of money from public officers before he would pay their salaries, had accepted money from planters who were in arrears with their rent, and, finally, had refused to lay his accounts before McCulloh for inspection. ${ }^{3}$

In the meantime the rent roll bill was being con-

1 Public Records, Ms., XXII, 8-10.

2 Glen was governor of South Carolina and Johnston of North Carolina.

3 Ibid., 30-39. 
sidered by the home government. The Lords of Trade, December 21, 1744, sent it to their special counsel for colonial affairs, Mr. Francis Fane, and asked his opinion thereon in point of law. ${ }^{1}$ He reported favorably, but still the royal approbation was withheld. ${ }^{2}$ Peregrine Fury, the agent of the province in England, presented to the Board of Trade, November 12, 1747, a number of arguments in favor of the bill. In the first place, he said that it was for the service of the crown because it required the registration of mesne conveyances under royal grants, thus overcoming the defects of the former quit rent law which merely provided for the registration of original titles and mesne conveyances of proprietary grants. This act, accordingly, furnished the officers of the revenue a better opportunity to keep up with the owners of land. The fifth clause would prevent the conveying of land to fictitious and transient persons and would allow it to be transferred only to those able to pay rent, since it required the grantee to be able to pay his rent for five years and the grantor to pay all arrears up to the date of transfer. In the third place, the act allowed those persons who held vast tracts of land which they were unable to cultivate to return them to the king so that they could be granted to others. To prevent the return of poor land alone, it was provided that whole grants and not parts might be surrendered, that all arrears of rent must be paid, and that no land could be surrendered which had been wasted, by making pitch, tar, or turpentine. He closed

1 Public Rccords, Ms., XXI, 410-411.

2 Ibid., XXII, 193-194, 198. 
his argument by calling attention to the final clause of the act, which was intended to relieve those persons, who, by reason of the errors of depaty-surveyors, had been made liable for rent on land which they did not possess. ${ }^{1}$

The fate of the act is unknown. In the absence of an adequate index, the records have been carefully searched, but no further reference to it can be found. The inference would be that it was not approved and hence never actually put in force. No further attempts were ever seriously made to improve the rent roll. The receiver-general continued to collect whatever he could, usually not over one-third of the amount really due.

This chapter concludes our survey of the king as territorial lord of the province. We have seen him in conflict with his people over two questions, the granting of land and the collection of rent. In both of these contests he was worsted. St. John, Whitaker, and McCulloh failed in their efforts to preserve the royal domain and to secure a more regular payment of His Majesty's quit rents. The causes of their failure are not far to seek. In the first place, the whole colonial administrative system of Great Britain was sadly defective. There was too much official red tape and too great a diffusion of responsibility. Disagreeable tasks were very likely to be shifted back and forth between the Board of Trade and the Secretary of State for the Southern Department. The Revolution owes quite as much to Newcastle's ignorance and apathy as it does

${ }^{1}$ Public Records, Ms., XXII, 330-334. 
to the intemperate zeal of Grenville and Townshend. ${ }^{1}$ A second cause of failure and a natural corollary to the first was the growing spirit of independence in the colony, which rebelled at any interference on the part of the home gorernment.

1 The Duke of Newcastle was Secretary of State for the Southern Department from 1724 to 1719 . His ignorance of colonial affairs was proverbial. 


\section{SECTION II}

\section{GOVERNMENT}





\section{CHAPTER I}

\section{The Executive}

Is the provinces the prerogative element was at first strong both in theory and in practice. Yet long before the actual revolt against the mother country began the colonists had shown their determination to govern themselves. The constitutional history of a royal province then should indicate the gradual process by which this change was brought about. The executive, as the representative of imperial control, should first be studied. The executive consisted of a governor and council selected by the crown, and of various other officials, some chosen by the crown and some by the provincial legislature. The governor was appointed by His Majesty in council on the recommendation of the Board of Trade. The English government of the eighteenth century, and especially during the Newcastle regime, was corrupt to the very core, hence we often find the office of governor in the colonies filled by needy dependents of borough-mongers, whose principal desire was to accumulate as much money as they could, without regard to the interests of the colony or the rights of the king. ${ }^{1}$

1 The best account of the provincial governor is to be found in Greene, Provincial Govcrnor, Hartard His. Studies, Vol. VII. I am indebted to his work for many valuable suggestions. 
The tenure was during the king's pleasure, and the authority of the governor ceased on the arrival of his successor and the publication of his commission. His position was insecure. Some other courtier might pay more for the place or have greater influence with the dispensers of patronage in London. Then again the governor was sometimes remored because of charges made by the colony agent, who, in practice, was usually the servant of the lower house of the legislature. ${ }^{1}$

In the absence or inability of the governor his place was taken by the lieutenant-governor. In case both were absent, the president of the council became acting executive, ${ }^{2}$ although he was forbidden, without a particular order from the king, to concur in any legislation not immediately necessary to the peace and welfare of the province. The two William Bulls, father and son, were for many years at the head of the government as lieutenant-governor. The president of the council was twice called to the executive chair, Arthur Middleton from 1725 to 1730 and William Bull from 1737 to 1738 .

The income of the governor consisted of his salary and various fees and fines. Going back into the proprietary period, we find that his salary was $£ 100$ in 1677 , $£ 200$ in 1702 , and $£ 400$ at the close of the period. ${ }^{3}$ Acts were passed in 1685, 1690, 1695, and 1698 regu-

1 Tanner in Political Science Quarterly, XVI, 24-49. Greene, Provincial Governor, 50-51.

2 The president was the senior member of the council. If several had been appointed at the same time, he was the first named in the commission.

${ }^{3}$ S. Car. His. Soc. Col., J, 101, 152, 172. 
lating fees. For signing various warrants, liquor and marriage licenses, testimonials, land grants, decrees in chancers, etc., he received fees ranging from two shillings six pence to five pounds. ${ }^{1}$ The power to regulate fees, thus secured by the general assembly during the proprietary period, was never given up, in spite of the fact that the governor and council were often instructed to regulate them by executive ordinance. He was allowed one-third of the proceeds arising from the sale of vessels condemned in the admiralty court for violating the acts of trade and navigation and usually some fraction of the fines and forfeitures collected.

The annual salary itself was granted by a vote of the general assembly and it was in the nature of a gift rather than a fixed allowance. The council, in a letter to the Duke of Newcastle, December 19, 1728, complaining of the conduct of the assembly, declared that the province was well able to fix a salary of five hundred pounds sterling on their governor. This was the amount which Moore and Nicholson had received, but it was considered as a gift rather than a definite salary. That is to say, the assembly claimed the right of withholding the governor's pay in case he would not comply with their demands. The government had in this way become so much weakened that it might be said "to have an executive power without a power to execute it." Nicholson was instructed to insist on the fixing of a salary and not to take any present after it had been so established. The assembly interpreted this to mean that the governor could accept gifts until they

${ }_{1}$ Statutes, II, 3, 39-40, 87, 144-145. 
provided a permanent salary. Consequently, they refused to make the provision and all the money which they paid the governor was in the nature of presentspresents, said the council, which were always given just after his assenting to a currency law or doing something else gratifying to the assembly. They suggested that an instruction be given to succeeding governors not to accept any gift from the assembly whatsoever. ${ }^{1}$

President Middleton incurred the hostility of the assembly by opposing their paper money schemes. As a result, his salary was withheld entirely for several years and he was finally paid only a small part of what was really due him. Seeing that the executive was being made a mere tool of the legislature, Governor Johnson tried to induce the assembly to provide a permanent salary. They delayed the matter on one pretext and another and finally refused openly to grant the request. ${ }^{2}$

The assembly does not seem to have made much use of the power to withhold the governor's salary entirely. They did, however, frequently delay the tax bill for months in order to force him to terms. Governor Boone did not receive one penny of salary until the arrival of specific instructions from the king demanding that he should be paid. It is not likely that the assembly would have yielded then had not the demand been made while they were rejoicing over the repeal of the Stamp Act. As it was, they adopted a committee report maintaining their right to withhold salaries whenever

I Public Records, Ms., XIII, 233-234.

2 Public Records, Extra, Its., I, Part II, 794-802. 
they pleased. ${ }^{1}$ In this connection it should be said that His Excellency was not the only one to feel the wrath of the assembly. Chief Justice Robert Wright, as we have seen, suffered severe financial loss for protecting the territorial interests of the crown.

The allowance of the governor during the entire royal period was $£ 500$ sterling, in addition to house rent, which was usually $£ 100$. As the exchange rate was seven to one, this appeared in the annual budget as $£ 3,500$ currency. The fees for a time brought in as much more. Governor Glen complained that his fees never amounted to more than $£ 300$ sterling per annum, though he had been assured before his arrival that they would be at least $£ 1,000$. Mr. Mickie, for many years secretary of the province, stated that they were seldom less than this. Glen attributed the decrease to the fact that he did not collect the full amount to which he was entitled by law. ${ }^{2}$ Probably the real reason was that Johnson and Broughton received a great deal in fees from the numerous land grants made by them.

There was always a clause in the instructions to the governor which provided that in his absence from the province one-half his salary should go to the lieutenantgovernor or to the acting executive. In 1745, Governor Glen put in a claim for one-half of all the salary paid to Lieutenant-Governor Bull between Glen's appointment as governor in 1738 and his arrival in the province

${ }^{1}$ Com. House Journals, Hs., XXXVII. Part II, 160-161, 165-166. See pp. $34 i-349$.

2 Message to the assembly, March 26, 1756, Ibid., XXXI, Part I, $153-154$. 
in 1743 . Bull sent a memorial to the assembly saying that during the period in question he had received an annual allowance of barely more than one-half the amount paid to Governor Johnson, and he did not think that he should be required to give half of that to Glen. The assembly referred the memorial to a committee, and, on March 21, 1746, adopted a report and resolutions to the effect that the money paid to Bull was a free gift for his services and was not intended to be divided with any one. ${ }^{1}$

As for the governor's powers and privileges, we find them laid down in his commissions and instructions, which formed the written constitution of the province. These documents were drawn up by the Board of Trade in consultation with the Treasury and Admiralty Boards and the law officers of the crown, and finally approved by order in council. The commission contained the general grant of power, the instructions prescribed in detail how it should be used, and often limited it. ${ }^{2}$ The commission was a letter patent and had to be published by the governor immediately on his arrival in the province; the instructions were to be published in whole, in part, or not at all, at his discretion, though he was instructed to communicate to the council those articles in which they were specially concerned. When a new governor came into the province he brought his commission and two sets of instructions, one having to do with the general constitution of the province and the other referring specifically to the acts of trade and navigation.

I Com. House Journals, Ms., XXI, 149-151, 433-435.

2 See Greene, Provincial Governor, 93-94. 
The general instructions to Governor Nicholson, dated August 30, 1720, consist of ninety-six articles and those in regard to trade and navigation, of twenty-four. ${ }^{1}$ The general instructions to Johnson, June 10, 1730, contain one hundred and twenty-four ; ${ }^{2}$ those to Glen, July 19,1739 , one hundred and ten $;^{3}$ those to Lyttleton, November 4,1755 , one hundred and seven $;{ }^{4}$ those to Boone, November 11, 1761, ninety-four ; ${ }^{5}$ those to Montagu, February 19, 1766, ninety-nine $;^{6}$ and finally, those to Lord William Campbell, June 20, 1774, ninety-four. ${ }^{7}$ In addition to these general instructions there were sent out from time to time additional instructions covering certain specific points. The governor's powers were still further determined by the laws of parliament and the provincial statutes. In theory very broad, they were much restricted by the continual encroachments of the popular branch of the legislature. With the advice and consent of the council, he was to call assemblies of the freeholders, the members of which were required to take the usual oaths. With the consent of the council and the assembly he was to make laws agreeable to the laws of England. He was to have an absolute veto power and could prorogue, adjourn, and dissolve assemblies. He was to see that no laws of an unusual or extraordinary nature were passed without a clause suspending

${ }_{1}$ Public Records, Ms., VIII, 101-138, 139-165.

2 Ibid., XIV, 147-214.

3 Ibid., XX, 66-139.

4 Ibid., XXVI, 267-344.

5 Ibid., XXIX, 132-181.

6 Ibia., XXX, 309-388.

${ }^{7}$ Ibid., XXXIV, 53-135. 
their operation until the king's pleasure could be known, and that no private acts were passed except with a clause saving the rights of the king and all persons and corporations not mentioned in the act. All laws were to be sent to England within three months after the passage, together with the date of passage and ratification and the governor's observations thereon.

The control of the executive over the finances, though apparently very extensive was really quite limited. He was authorized, with the advice and consent of his council, to regulate all salaries and fees, but, as we have seen, fees had been regulated from the earliest years of the province by act of the general assembly, and this continued to be the custom. The salaries of officers elected by the general assembly were determined by statute. The salaries of those crown officials who were paid from the quit rents were fixed by the king; those who were paid out of the public treasury, as, for example, the governor, the clerk of the assembly, and for a time the chief justice, were at the mercy of the lower house. Though it was rare for salaries to be withheld entirely, they were often reduced or delayed. No public money was to be disposed of otherwise than by warrant under the hand of the governor, by and with the consent of the council. As will be seen in a subsequent chapter, this clause did not prevent the assembly from so far getting control over the finances as to order money paid out of the treasury without the knowledge or consent of the governor and council. ${ }^{1}$ In early times the chief executive was allowed some discretion in disposing of money voted by the general assembly, but the assembly

${ }^{1}$ See pp. $369-386$. 
soon began to designate in detail for what purposes it should be expended. Accounts were regularly considered by a committee of the assembly and their report acted upon by the whole house. Either the governor or the council could reject the appropriation bill as a whole, but neither was allowed to make any additions or amendments.

As administrative head of the province the governor's powers were likewise very shadowy. He appointed all military officials, and, with the advice and consent of his council, judges and justices of the peace. On good and sufficient cause signified to the king and the Board of Trade, he could remove judges, justices, sheriffs, and other officers. His real position in the administration, however, is well described in a letter from Governor Glen to the Duke of Bedford, dated October 10, 1748. Glen complained that almost all places of trust and profit in the province were disposed of by the general assembly, which in practice meant the lower house. They appointed the treasurer, the commissary, the Indian commissioner, the controller of the duties upon imports and exports, the powder receiver, and various others. ${ }^{1}$ The executive part of the government was lodged in different commissioners. Thus there were the commissioners of the markets, of the workhouse, of the pilots, of the fortifications, and so on without number. Nor did they stop at civil posts, but all ecclesiastical preferments were at the disposal of the people, though by his instructions the power of collating to

1 A law of 1707, repealed in 1721, gave the lower house alone the power of appointing these officials. See introductory chapter. 
livings was vested in the governor. Most of these commissioners were named by the general assembly and were accountable to them only. "Thus by little and little the people have got the whole administration into their hands, and the crown is by various laws despoiled of its principal flowers and brightest jewels.",

The governor's commission empowered him, with the adrice and consent of his council, to erect and establish such courts of judicature, civil as well as criminal, as they should think fit. The instructions, however, limited this power by providing that he was not to "erect any court or office of judicature not before erected or established, nor dissolve any court or office already erected or established without His Majesty's especial order." The common law courts had thus been established by executive act before the overthrow of the proprietary government. The assembly, however, encroached upon this power by passing numerous judiciary laws. The governors were usually instructed to establish a court of exchequer, though, with the exception of an abortive attempt during Johnson's administration, no effort to do this was ever made. ${ }^{2}$ They were empowered to appoint judges, commissioners of oyer and terminer, justices of the peace, and other necessary judicial officers, and to see that courts of justice were duly and frequently held and that justice was impartially administered. The governor and council constituted a court of chancery and the supreme court of appeal in civil cases involving a certain amount, at first

I Public Records, Ms., XXIII, 234-236.

${ }^{2}$ Ibid., XXXII, 379-380. 
$£ 100$, later $£ 500$ sterling. This last power was rarely, if ever, exercised. ${ }^{1} \quad$ The governor alone exercised the jurisdiction of ordinary for granting marriage licenses, probate of wills, and administration of the estates of intestates. Finally, he was empowered to pardon all offenses, except treason and willful murder, and to remit fines and forfeitures under ten pounds. In the excepted cases he could reprieve or suspend payment until the pleasure of the king be known.

As ecclesiastical head of the province, the powers of the executive were very limited. He was to take care that God should be devoutly worshipped, that churches should be built and kept in good order, and that none but ministers in orders should administer the sacraments. The commissions and instructions both empowered him to collate to benefices, but, as we have seen, the church act of 1706 conferred this power upon the Anglican freeholders of the separate parishes, and it was retained by them throughout the entire colonial period.

His military powers were more extensive and more real, but here too we find evidences of the encroachments of the popular element. This will be treated more in detail in a later chapter. Here it will be sufficient to point out briefly the provisions in the commissions and instructions bearing on this subject. He was given full power and authority to levy, arm, muster, command, and employ all persons whatsoever, residing in the province, to use them both within or without the province, to appoint all officers, and, with the advice and cousent

${ }^{1}$ Public Records, Ms., XXXII, 375. 
of his council, to build, equip, and dismantle forts and fortifications, and declare martial law. As rice-admiral he had control over the colonial fleet with power to appoint captains, lieutenants, masters of ship, and other officers, but, inasmuch as the navy never consisted of more than two small scout boats and two galleys, the duties of this position were not very onerous. He was empowered to grant letters of marque and reprisal against princes or states not in amity with the king of England, and to punish offenders against maritime law. These powers were exercised largely through the court of vice-admiralty which sat at Charleston. Pirates were tried under a special commission from the crown, the chief commissioner being the judge of the admiralty court.

The diplomatic or quasi-diplomatic powers of the executive were exercised in connection with the relations of the province to the Indians and to other colonies. The governor and council could declare war against the Indians in an emergenes, and they also made treaties of peace with them, though the power was not expressly granted. The governor's powers in regard to Indian affairs were very much restricted after 1756 through the appointment of a special crown officer, known as the superintendent of Indian affairs. The negotiations with the neighboring colonies of Virginia, North Carolina, and Georgia were mainly in regard to Indians and boundary disputes.

In addition to these ordinary functions of the governor, mention should be made of several miscellaneous powers and duties. His position as the king's land 
agent has already been discussed. He was empowered, with the advice and consent of his council, to establish fairs, marts, markets, ports, and harbors. The assembly encroached upon this power by passing two acts in February, 1724 , one for settling a fair and markets in the town of Dorchester in Berkeley County and a similar act for Ashley River Ferry Town also in Berkeley County. ${ }^{1}$ He was required to send to the Board of Trade maps of the territory under his gorernment, lists of officers, a particular account of all establishments of jurisdictions, courts, and offices, and a semi-annual account of the revenue raised and disbursed. Journals of the council and assembly were to be sent over to England regularly. Separate instructions required him to see that the trade and navigation acts were strictly enforced. Finally, the governor and council were empowered to do anything for the good of the province, whether specifically instructed to do so or not, provided that they were not to declare war without His Majesty's consent, except against Indians in emergencies, and provided they should at once make known their action to the Board of Trade and to one of the king's secretaries of state.

The second branch of the executive department was His Majesty's council. The duties of this body have already been touched upon in discussing the powers of the governor. A few words should be said in regard to its personal constitution as provided for in the governor's instructions. There were twelve members of

${ }^{3}$ Statutes, III, 214-219. 
the council named in the instructions to each governor. ${ }^{1}$ In addition to these, the surveyor-general of the customs for the southerm district of America and later the superintendent of Indian affairs were members extraordinary. These men were appointed by the crown usually on the governor's recommendation. The governor, on his arrival, administered the oaths of office to them and read his commission and those articles of his instructions in which their advice and consent were required. He was to allow them freedom of debate and vote. Any three of the council constituted a quorum, but the governor was not to act with less than five members except in an emergencr. He was required to make up a list of the names of twelve persons fit to serve as councilors and send it to the Board of Trade and one of the principal secretaries of state. From this list they filled vacancies. In case the number of councilors in the province fell below seven, the governor could appoint up to that number, but the names and qualifications of his appointees had to be at once submitted to the Board of Trade for ratification. The governor was forbidden to augment or diminish the number of the council as thus established or to suspend any of the members without good and sufficient cause or without the consent of a majority of the council. In case, however, he should have reasons for suspending a councilor, not fit to be communicated to the council, he might dispense with their consent. In either case he was required to submit to the home government at once the reasons

1 Except in those to Nicholson. He selected his own council after his arrival in the province. 
for his action together with the reply of the suspended party. Councilors absent from the province a certain length of time lost their positions.

The functions of the council have already been considered in part. They were an executive board, a court of judicature, and the upper house of the legislature. His Excellency presided over them when sitting in their executive or judicial capacities, and usually before 1739 when they sat as a legislative house. The anomalous position of this body is shown by the fact that the governor sometimes asked their opinion as a council whether he should sign bills which they had already passed as the upper branch of the legislature. Up to about 1760 the members were regularly chosen from among the wealthiest and most influential men of the province. Being men of wealth, city merchants and importers, they were conservative and willing to be dependent upon the crown rather than to suffer from the paper money vagaries of the planter element in the assembly. After 1760 , they were selected from the class of office-holders and placemen, carpet-bag politicians, who had no other interest in the province than to fill their capacious pocketbooks. Accordingly, throughout the entire colonial period the council inclined to support the governor in his struggle with the assembly. What we have termed the conflict between the prerogative and popular elements in the government was really, then, similar to the long constitutional struggle in England between the executive and the legislature. Side by side with the governor was a body both executive and legislative in form, but executive in spirit; strictly speaking, a body 
analogous neither to the House of Lords nor to the Privy Council, but rather to the product which would result from the blending of the two.

The most important of the other executive officials were the lieutenant-governor, surveyor-general of the lands, register, auditor, receiver-general of the quit rents, attorney-general, secretary of the province, provost marshal, and comptroller of the customs, appointed by the crown; and the public treasurer, country comptroller, commissary-general, powder receiver, commissioner for Indian affairs, and the commissioners of fortifications, pilots and others, elected by the general assembly. The functions of these officials are for the most part explained by their titles. Some of them will be referred to more in detail in subsequent chapters. 


\section{CHAPTER II}

\section{The Legislature}

A Brife account of the early history of the legislature has already been given in the introductory chapter on the proprietary period. To recapitulate, there was at first a grand council of ten members, one half chosen by the proprietors and the other half by the freeman. This body for a time exercised all the powers of government, legislative, executive, and judicial. The freeholders were also empowered to elect a parliament of twenty members, who, with the five deputies of the proprietors, were to constitute the legislative department. The power to initiate legislation was reserved to the grand council. In 1692, the parliament began to be known as the general assembly, was divided into two houses, and the elective element dropped out of the council. A year later the lower house secured an equal power of initiation with the upper. The council consisted of seven members, one deputy for each proprietor, from this time until near the close of the proprietary period. The attempt then made to increase the number was regarded as a grievance by the popular party. This form of government was retained when the province fell under the king's control, though the royal commission and instructions to Governor Nicholson defined a little more clearly the structure and 
powers of the council and its relation to the other branches of the legislature.

The government was based upon the English model. Corresponding to the king and privy council were the governor and his council; to the legislative branches of king, lords, and commons, were the governor, council, and commons house of assembly. In addition, the king himself, or rather the British ministry, constituted what we may term a fourth branch of the legislature. The instructions to the governor usually suggested such legislation as the home government desired to see enacted. Moreover, there were some matters which the colonial legislature could not consider at all without consent first being obtained from the crown. Certain other measures could not be put in force until notice was received of His Majesty's approval. Ordinary laws went into operation at once but they became void if the king disallowed them. It was an open question as to whether the home govermment could nullify an act after they had once approved it. For this reason they rarely gave any measure their approbation, but merely let it remain in force under sufferance. In case it gave trouble it could be more easily repealed.

Of the three branches of the legislature in the colony we come first to the governor. Reference has already been made to his legislative functions in the chapter on the executive. He had an absolute veto power and the privilege of recommending legislation by message.

The appointment, tenure, number, and qualifications of the councilors have also been considered. A few words may here be said in regard to their powers, 
privileges and methods of procedure as a legislative body. They occupied a position analogous to that of the British House of Lords. In theory they had the same powers as the lower house, but in reality very much less. In spite of the royal instructions that they should have "the like power of framing, mending, or altering money bills as the assembly," the lower house refused to allow any interference on their part. All that they could do was to reject money bills as a whole. This they sometimes did when the house made some particularly extravagant claims. The assembly would then refuse to proceed on further business, no taxes could be raised, the governor's salary fell into arrears, until finally so much pressure would be brought to bear that the council would be compelled to give way. This mastery over the public purse gave the commons house ${ }^{1}$ almost entire control over legislation. All officials chosen by statute were really their choice. Several conflicts arose over the appointment of the public treasurer and the colony agent, but the governor and council always had to yield. Finally, as we shall see, the power of the council to initiate legislation or even to sit as an upper house at all was questioned.

The members of the council were to have freedom of debate and vote on all matters of public concern, and they were exempt from arrest during the sitting of the general assembly.

In studying the organization and procedure of this body its double, or rather triple, character must be kept

1 The lower house is in its journals usually called the commons house of assembly, sometimes the assembly, and again merely the commons house. 
in mind. As a branch of the legislature, it sat only when the lower house was in session. Since it often met in its executive and judicial capacities during the recesses of the general assembly and since its members held by an indefinite tenure, there was no need for organization at the beginning of each legislative session, as was the case in the assembly. During the proprietary and the early years of the royal period, His Excellency had a seat in the council in its legislative as well as in its executive and judicial capacities. The result of this was inextricable confusion in the journals. After 1731 the executive body was termed in its journals, the council or our board, the legislative, generally, the upper house of assembly. An attempt was also made to keep the journals separate, though some confusion was caused by the refusal of the assembly to use the term upper house. On April 11, 1739, the upper house resolved that the presence of the governor or commander in chief during the sitting of the house was of an umparliamentary nature and that they would enter into no debates during his presence. 'They had good precedents for this. Richard West, special counsel to the Board of Trade, had given an opinion in 1725 that the gorernor could not legally vote when the council was sitting in a legislative capacity. ${ }^{2}$ In January, 1736, as the result of a contest in New York, the Board of Trade decided that Governor Cosby was neither to sit nor to vote in the council while it was acting as a branch of the legislature. ${ }^{3}$ When Governor Glen arrived in the

${ }^{1}$ Council Journals (Upper House), Ms., VII, 218.

2 Chalmers, Colonial Opinions, 238-239.

3.T. Y. Col. Doc., VI, 39-40. 
province in December, 1743, he became angry at the attempt to exclude him from the legislative council, and made a speech endearoring to show from the practice of the other provinces and the home government that he had a right to be present. His exclusion, he declared, was contrary to the British constitution, "for that the King's Throne in the House of Peers was not placed there as an ornament to the Room, but because he had a right to be there, and the Lord Coke says that the Parliament is composed of two houses. The King and House of Lords make one House, and the House of Commons is the other." He went on to say that lie had the same right to be present that the king had in the House of Lords. ${ }^{1}$ Whether or not the council were as ignorant of the British constitution as Governor Glen and were convinced by his arguments is not known. At any rate, they agreed that he might be present, provided he would never take any part in the debates or receive any messages coming to their house or give answer thereto. ${ }^{2}$ Glen did not like this purely ormamental position and made the serious mistake of joining hands with the lower house in an attack on the legislative powers of the council. He seems to have attended the meetings occasionally until 1749 , and then to have ceased altogether. Finally, he came into their chamber on April 29, 1756, as they were reading a message previously sent by him. The reading was at once postponed and the louse adjourned to the afternoon. ${ }^{3}$ After that I can find no further reference to

1 Public Records, Ms., XXIII, 240-241.

2 Council Journals, Ms., XII, †.

${ }^{3}$ Council Journals (Lpper House), IIs., XXIV, Part II, 60. 
the presence of the governor in the legislative council. A committee report of the upper house, adopted May 7,1745 , during the controversy with Glen, calls attention to the confusion caused by the governor's presence in their chamber. The report says that the legislature of the province consisted of three distinct and separate branches after the model of the mother country, "neither of which therefore ought or can mix or blend itself with either of the others or be set aside by the other two;" that the consent of the council and the consent of the governor were to be obtained separately; that there was the same authority for terming the council in its legislative capacity a house as there was for terming the assembly a house; that the governor, being a separate and distinct branch of the legislature had no more right to be present in the legislative council than he had to be present in the assembly; that his presence in the upper house had caused much confusion. A comparison of the journals of the council and upper house would show that both often met the same forenoon or the same afternoon. The governors had not been content to call meetings before or after the assembly business was done, but would have council meetings at intervals between and would continue to sit in the great chair of the council chamber when the upper house met. The result was that members of the assembly coming up with messages were at a loss to know who was the president, as at one time the body would be a council, then again, an upper house. Nay, sometimes judicial matters came up and it was suddenly turned into a court of chancery. This had caused con- 
fusion in the journals, the clerk often speaking of the upper house as the board, and sometimes even the members used this language. ${ }^{1}$

Messages from the upper house to the lower were signed sometimes by the governor and again by the governor and the president of the council jointly. After 1739, however, though the governor continued to preside over the council and to sign messages from it to the assembly, the president or senior councilor presided over the upper house and signed its messages. Other officers of the upper house were the clerk, messenger, doorkeeper, and an official known as the master in chancery, who, among other duties, carried messages to the assembly. The salaries of these officials as shown in the estimates for the year 1751-1752 were: to the clerk, $£ 300$; to the master in chancery, doorkeeper, and messenger, $£ 200$ each. $^{2}$ The master in chancery, William Pinckney, was at that time also deputy secretary of the province.

The third branch of the legislature was variously known as the lower house, the house, the commons house, the assembly, and the commons house of assembly. The constitution of this body can best be studied from the several election laws passed at different times. The first statute on the subject, entitled, "An Act to Regulate the Election of Members of Assembly," was passed October 15, 1692.3 It was repealed by the Lords Proprietors, April 10, 1693, because it allowed all persons to vote who made oath

1 Council Journals, Ms., XIII, 170-172.

${ }^{2}$ Com. House Journals, Ms., XXVII, 470.

${ }^{3}$ Statutes, II, 73. Title only. 
that they were worth over ten pounds. The proprietors said that this would allow pirates to rote and that only freeholders should possess the franchise.' Another law, enacted in 1694, provided for biennial elections and forbade a discontinuance of the sittings of the general assembly for more than one year." An act of November 4, 1704, is the first complete election law that has been preserved. The sheriffs of the counties were made returning officers, and elections were by ballot. Residence in the county or precinct from which a member was returned was a necessary qualification. ${ }^{3}$ The next act, that of December 15, 1716, made the parish the unit of representation. ${ }^{4}$ The church act of 1706 divided the province into parishes, and, as it was very inconvenient for all the people to go to Charleston to cast their rotes, it was decided to make use of these divisions. Any person possessing personal property worth five hundred pounds currency or five hundred acres of land in a parish was eligible to election from that parish. This seemed to imply that a man could stand for any parish in which he had the requisite amount of property. An additional act, passed June 29,1717 , made residence in the parish a necessary qualification. ${ }^{5}$ The repeal of these two laws by the proprietors, July $22,1718,{ }^{6}$ was one of the grievances which led to the revolution. An act very similar

1 Rivers, Sketch of the His. of S. Car., 437.

Statutes, II, 79-80.

3 Ibid., 249-251.

Ibid., 683-691.

5 Ibid., III, 2-4.

6 Ibid., 31. 
to them, but containing some important changes, was passed March 20, 1719. According to this members were neither required to live nor to hold property within the parish from which they were elected. There was the usual property qualification, but it might be anywhere within the province. This was an important innovation and it was followed in subsequent acts. Another important feature of the law was that nineteen members were to constitute a quorum of the house. ${ }^{1}$ This act was likewise repealed by the proprietors, but the repeal was disregarded and the law declared still in force by the reviving and continuing act of February 12, 1720.'

After the province had been taken under the government of the crown, there was passed, September 19, 1721, "An Act to ascertain the manner and form of electing members to represent the inhabitants of this Province in the Commons House of Assembly, and to appoint who shall be deemed and adjudged capable of choosing or being chosen members of the said House."'3 This remained the election law of South Carolina until after the establishment of commonwealth government during the Revolution.

The third section provided for the qualifications of electors. Every free white man over twenty-one years of age, professing the Christian religion, a resident of the province for one year before the issue of the writs, and possessing a freehold of fifty acres or pay-

1 Statutes, II, 50-55.

${ }^{2}$ Ibid., 55, 103.

3 Ibid., 135-140. 
ing twenty shillings a year tax might vote in the parish in which he lived or in any other in which he had the requisite qualifications. I do not think that this could be interpreted as giving to any person the right to vote in more than one parish at the same election.

Section eight provided for the qualifications for members of the assembly. To be eligible, a man had to be a freeborn subject of Great Britain or the dominions belonging thereto, or a foreigner naturalized by act of parliament, twenty-one years of age, a resident of the province for twelve months, and owner of five hundred acres of land and ten slaves or else of houses and town lots worth one thousand pounds. Following the act of 1719 , residence in the parish was not required.

Within these limitations the house was to judge of the qualifications of its members. The election law provided that each member should take certain state oaths before the governor. On two or three occasions His Excellency took advantage of this to pass upon the credentials of members and as a result became involved in disputes with the assembly. In April, 1725, Governor Nicholson refused to administer the state oaths to James Akin, returned from the parishes of St. Thomas's and St. Dennis's. In reply to the remonstrances of the house, he sent a copy of the thirty-fifth article of his instructions, with a mark calling special attention to the last section, which enjoined him not to allow to the assembly in South Carolina any power or privileges whatsoever not allowed by His Majesty to the members of the House of Commons in England. He went on to say that a bill of indictment found by 
the grand jury was hanging over Akin, for which he was to be tried before the superior court on the following Wednesday, and that he could not qualify him until he was acquitted, unless the assembly were able to find from the journals of the English House of Commons a case where such a person had taken his seat. The assembly cited as a precedent a case which came up in the twenty-third year of Elizabeth's reign, where a member of the Commons was indicted for felony and it was decided that he should remain a member of the house until convicted; otherwise, innocent persons might be deprived of their seats. Sir Matthew Hale's treatise on The Original Institution, Power, and Jurisdiction of Parliament was given as the authority. ${ }^{1}$

Mr. Akin did not take the oaths until May 13, about three weeks after the date set for his trial. Whether he was convicted or not the records do not show, but it certainly looks as though Governor Nicholson carried his point. ${ }^{2}$

The second case was of a religious character. Thomas Lynch, Charles Lewis, Michael Darby, James Stobo, William MeMahan, and John Bee, Protestant Dissenters, were elected to the assembly which met January, 1728. President Middleton refused to qualify them because they would not take the state oaths on the Evangelists. He defended his position by an appeal to the election law of 1721 and also to the thirty-fifth article of the governor's instructions, the same that Nicholson

1 'This work, published in London in 1707 , is now regarded as spurious. See article of Hale, Dict. of Nat. Biog., XXIV, 23.

2 Com. House Journals, Ms., VII, 176-177, 180-181, 200. 
had cited in the Akin case. His argument was that, inasmuch as the members of the House of Commons in England were required to take the state oaths on the Evangelists, the members of the assembly in South Carolina must do the same. A bill was at once passed throngh the house for enabling these men to qualify according to their profession. The passage of this would have obviated the objection based on the election act, though not that based on the royal instructions. But it was not to pass, for the council rejected it on the 11th by unanimous vote, saying that they could not anticipate the royal will by passing such a measure. The assembly acquiesced in this settlement of the matter and requested the issue of writs for new elections to fill the vacancies. ${ }^{1}$

The Gadsden case, the most important of all in its results, will be considered in detail in the final chapter. ${ }^{2}$

The election act of 1721 apportioned the representatives as follows:

\section{Parish.}

Members.

St. Philip's Charleston................... 5

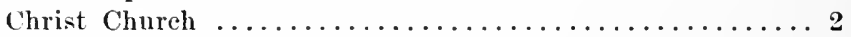

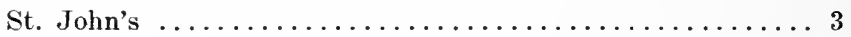

St. Andrew's $\ldots \ldots \ldots \ldots \ldots \ldots \ldots \ldots \ldots \ldots \ldots \ldots \ldots \ldots \ldots \ldots \ldots \ldots \ldots$

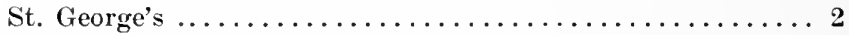

St. James's Goose Creek....................4

St. Thomas's and St. Dennis's............... 3

St. Paul's .......................... 4

St. Bartholomew's . . . . . . . . . . . . . . . . . . 4

St. Helena's ....................... 4

St. James's Santee with Winyaw...............

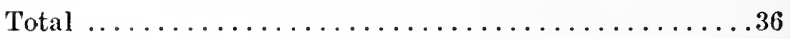

${ }_{1}$ Council Journals, IS., IV, 116, 119, 120-121, 124-127.

2 See pp. $340-347$. 
As the province grew, new parishes were created and new representatives added. By 1770 there were fortyeight members from twenty-two parishes. ${ }^{1}$ Still the addition of representatives was by no means in proportion to the development of the province. At the time of the Revolution and for many years afterwards, the low-country people were far better represented than their neighbors in the interior.

Forty days before the time appointed for the meeting of the general assembly, election writs were issued by the governor and council, directed to the church wardens of the several parishes, or, in case there were no wardens, to such other persons as the governor and council should select. These wardens or other election officials were required to take an oath before a justice of the peace of their county that they would faithfully execute the writs. Public written notice was given two Sundays before the election either at the door of the parish church or at some other place mentioned in the act. The polls were kept open two days, from nine in the morning to four in the afternoon, and were presided over by the wardens. The wardens notified the persons elected by posting their names on the door of the parish church within seven days after the election.

On the day appointed the members-elect met at Charleston. After a quorum of nineteen appeared, the lower house organized by electing a chairman. A verbal message was sent to the governor by two of the members desiring to know when he would be pleased to administer the state oaths. The governor sent down a

${ }^{3}$ Public Records, 1 s., XxxiI, 373. 
verbal message by the master in chancery saying that he was ready. All the members present then went up to the council chamber and took the state oaths. Returning to their house they took the oath of qualification as members of the assembly before some one of their number who was a justice of the peace. The chairman then informed the house that His Excellency desired them to choose a speaker. They proceeded to the election and then sent two members up to the council chamber with a verbal message that they had chosen their speaker and were ready to present him to the governor for his approbation. The governor announced his readiness to receive them, the members of the house chose two of their number to present the speaker, and went to the council chamber in a body. The speaker was presented and the governor signified his approval. Following the English custom, the speaker then made a speech desiring that the house might have liberty and freedom of speech and all their just privileges. His Excellency agreed to allow this and the house, retiring to their own chamber, chose their other officers. The next business was to receive the returns of the church wardens. One of the wardens from each parish brought in the election writ, together with a return that an election had been held on the specified date and that the persons named in the return had been duly elected.

After passing on the credentials of members, the assembly was again summoned to the council chamber and the governor addressed both houses, sometimes speaking to one, sometimes to the other, and again to both collectively, telling them of the nature of the business 
to be done during the session. Retiring to their own chamber, the house prepared an address in answer to the governor's speech and sent it up by two or three of their number. Members who had been elected from more than one parish now made known for which they intended to sit, and the house notified the governor and council of the vacancies thus caused, and asked that writs for new elections be issued. Vacancies were also caused by the refusal of members to serve or to take the oath on the Evangelists. The assembly was now ready to begin the regular routine business of the session. Standing committees on religion, privileges and elections, grievances, trade, and courts of justice were appointed. The anuual tax bill was introduced and petitions were read and referred to the proper committees.

The members of the assembly possessed as extensive powers and privileges as "any member or members of the Commons House of Assembly of the province heretofore of right had, might, could, or ought to have in the province," provided they were in accordance with His Majesty's thirty-fifth instruction. This article in Governor Nicholson's instructions enumerated certain privileges which were not to be allowed to the assembly. They were not to adjourn themselves, except for very short periods, without the consent of the governor; they were not to arrogate to themselves the sole control over money bills; and finally they were not to exercise any power or privilege not allowed by His Majesty to the House of Commons in Great Britain. The assembly maintained that this instruction guaranteed to them all 
the power's and privileges of the British House of Commons. They possessed the same exclusive control over financial measures which the House of Commons had. When His Majesty said that the council must have an equal share in framing money bills, he referred to acts providing for the issue of paper currency, and not to the ordinary supply bills. Having carried their point, ther were able by withholding supplies to exercise considerable influence over all legislation and to a large extent over matters purely executive in character.

The privileges of members were about the same as those of the councilors. They possessed freedom of debate and rote, and were exempt from arrest during the sitting of the general assembly. The privilege last mentioned might, howerer, be suspended by a rote of the house. Thus, in April of 1726, Captain Richard Smith, a member of the assembly, was arrested for debt. The house demanded his release and instructed their messenger to take the provost marshal into custody. Smith wrote to the assembly requesting them to waive his privileges, as he intended as soon as possible to pay his debts like a man of honor and secure his release. The house agreed to the request. ${ }^{1}$ Then again, in 1754 , Thomas Wright was imprisoned on a writ issued by David Graeme, an attorney at law. Wright was released on the demand of the house, but a resolution, adopted on March 2, indicated the power to suspend the privileges of the assembly. Thus they resolved that Graeme was guilty of a breach of their privileges in issuing a writ for the arrest of a member "without

1 Com. House Journals, ifs., VII, 336-343. 
having Privilege of Assembly.", The right to imprison for contempt was also claimed as a privilege of the house. The two most famous cases in which the right was exercised were that of the merchant petitioners against the paper money act of 1722 and that of Dr. Cooper and others during the controversy over land grants in 1733 , both of which are discussed in other connections.

The legislative procedure in South Carolina differed in one very important respect from that used in the British parliament. In parliament bills were read three times in one house and then sent to the other. In the colony they were read three times in each house alternately. There were numerous disputes in regard to the method of suggesting amendments, especially in the case of money bills. Toward the close of 1725 a quarrel over this subject delayed the passage of the annual tax bill. After the measure had passed the commons on its second reading, the council inserted some amendments in the body of the bill, according to the usual custom. The lower house struck them out and passed the measure on its third reading. On its final passage, the council re-inserted the amendments. The lower house resolved that it was unparliamentary to amend any bill after it had been read three times, and especially a money bill. After some discussion the council yielded and the measure was passed. The attempt to decide upon a definite method of procedure for the future was unsuccessful. $^{2}$

${ }^{1}$ Com. House Journals, Is., XXIX, 163.

2 lbid., VII, 256, 287, 235, 298-299, 301-310, 314-317. 
A similar dispute in 1739 led to the adoption of a final plan of procedure. A joint committee agreed upon the following compromise, which was accepted by the two houses:

"First. That bills shall be read alternately three times in each house.

"Second. That either house shall amend on the first and second reading.

"Third. That if the bill arises in the upper house, the same house may also amend on the third reading.

"Fourth. The same rule to be observed by the upper house if the bill arises in the lower house.

"Fifth. But if a bill which arose in the upper house and passed there a third time is thought necessary to be amended in the lower house on a third reading in the lower house, such amendment shall not be made before a conference be desired by the lower house on such amendments.

"Sixth. The same rule to be observed by the upper house if the bill arises in the lower house.

"Seventh. In case of subsidy bills, if the upper house shall think any amendments necessary to be made therein, that house shall make a schedule of the amendments proposed and send them down with the bill to the lower house, and the amendments, if they are approved of by the lower house, shall be read and passed by the lower house and added to the bill and then be returned to the upper house to be passed by them."

The only real controversy was over the seventh article. The council agreed to it because of the dangers from foreign war and domestic insurrection, ${ }^{2}$ but said

'Com. House Journals, Ms., XII, 188-191.

2 The Stono slave uprising had occurred just three months before this, in September, 1739 . 
that they suspended their just claims to amend money bills only with the proviso that this agreement should not be claimed or admitted as a precedent for any future assembly. ${ }^{1}$ The lower house also resolved that their consenting to a conference committee on the method of passing bills should not be regarded as a precedent, as they already had the sole control over money bills and had agreed to this arrangement merely to preserve harmony. ${ }^{2}$

This method of suggesting amendments was readopted by succeeding assemblies until 1745 , and, although not formally renewed after that time, continued to be the practice until the end of the colonial period. ${ }^{3}$ The lower house, however, regularly disregarded amendments to money bills and soon refused to receive them at all. At the instance of the assembly, the British plan of reading measures three times in one house before sending them to the other, was adopted in 1748 . The change does not seem to have given satisfaction, however, for the old custom was re-established at the beginning of the following session. ${ }^{4}$

Following the act of 1719 , the law of 1721 provided that nineteen members should constitute a quorum. This remained fixed until the Revolution, although, as we have seen, the number of representatives was increased to forty-eight. Governor Glen, in a letter to the Duke of Bedford, dated October 10, 1748, com-

${ }^{1}$ Com. House Journals, Ms., XII, 195.

2 Ibid., 211-212.

${ }^{3}$ Public Records, Ms., XXXII, 326-327.

- Com. House Journals, Ms., XXIII, 162-163, 191-192, 197-198, 218219, XXIV, 183. 
plained that members frequently absented themselves on purpose to break a quorum and obstruct business, and suggested that the number required be decreased. $\mathrm{He}$ said that seventeen and eighteen members would often meet day after day and he would be compelled to prorogue them for lack of a quorum. ${ }^{1}$ Seven members might meet and adjourn from day to day and summon absentees to attend. Ten affirmative votes were necessary to enact a law.

The efforts of the executive to continue the existence of a legislature indefinitely was a grievance common both to the colonies and to the mother country. Fortunately this question was settled in South Carolina before the downfall of proprietary rule. The biennial provision in the act of 1694 remained in force until superseded by the election law of 1721. The latter measure provided that every general assembly should be dissolved within three years from the date of issue of the writs and that meetings should not be discontinued for a period longer than six months.

This provision was put to a test in the very assembly which passed it. The writs were issued June 16, 1721, so the terms of the members would expire June 16, 1724. The election was held at a time when the people were rejoicing because the king had approved the revolution of 1719 and taken the province under his own control. Governor Nicholson saw that the enthusiasm was waning and that a new assembly would be less loyal to His Majesty's interests. Consequently, on June 10 , he recommended the passage of an act extending

${ }^{1}$ Com. House Journals, Ms., XXIII, 244-245. 
the existing assembly to October, 1725 , a period of sixteen months. If this were not done, he threatened not to call another election until he received commands from Great Britain, or until it was absolutely necessary for him to do so. The house replied that they could see no reason for extending the assembly beyond the time limited by law, and that they felt sure the governor and council would call a new one whenever the interest of the province should demand it.

On Monday the 15th, His Excellency sent down a letter just received from the agent in England and urged the house to consider it at once. At the same time he suggested that they could dispose of all the business before them during the week, and there would be no need for another meeting until fall or spring. They assured him that there was no necessity for extending their session and begged him to call a new assembly at once. The message was sent by Captains Simmond and Seabrooke. They reported, on their return, that they had read part of it to His Excellency when he exclaimed, "Go, I'll call an assembly when I please." He sent down a rather petulant message saying that the later a new assembly was convened the better it would be, since bad men would be elected who would work the country's ruin.

The following day the commons informed Nicholson that their session would terminate that day according to law and announced their readiness to pass such laws as were before the general assembly and to dispatch other necessary business. As he still refused to dissolve them, a resolution was adopted declaring that the ses- 
sion of the general assembly was by law at an end. A minute from the Council Journals of the following day says, "The Commons House having without the consent of this House, broke up, though they had a message to the contrary, His Excellency was pleased to send for their clerk, and declared that he looked upon it as arbitrary, illegal, and like their commonwealth principles (brought from New England) next to a Rebellion." 1

There was no other attempt made to extend an assembly beyond the three year's' limit. A law of 1745 provided for annual elections and another of 1748 for biennial elections, but both were rejected by the king and the old triennial act remained in force.

It was more difficult for the commons to enforce the other provision that sessions of the house should not be discontinued for a period longer than six months. After Nicholson's assembly dissolved itself in June, 1724, the new one did not meet until the following February. As a rule such infractions were not the result of any scheme on the part of the governor to deprive the people of representation, but were simply due to the fact that it best suited the convenience of the members.

The officers of the lower house were the speaker, clerk, messenger, deputy messenger, and cashier. There were three distinct steps in the election of a speaker. When a new assembly met they first obtained leave from the governor to organize and choose their

${ }^{1}$ Com. House Journals, Ms., VII, 37-38, 39, 56-57, 58-59, 61, 70; Council Journals, $1 / \mathrm{s}$., II, 306. For a discussion of the influence of New England on the other colonies, see Greene, Provincial Governor, 177-180. 
officers. Then, the speaker was chosen by ballot, and, finally, he was sent to the governor for his approbation. This brought up two questions: Was it necessary to obtain His Excellency's consent before proceeding to election? Did the right to approve imply the right to disapprove and require a new choice? Henry Middleton was elected by the house, January 27,1747 , to succeed William Bull, Jr., resigned. Governor Glen raised the objection that they had no right to make such a choice, even in the midst of a session, without first obtaining his leave. He gave up the point, however, on being shown that the assembly proceeded in the same way, in 1744, when Bull succeeded Judge Whitaker. ${ }^{1}$ The right of approbation soon became a mere formality. Lord Charles Greville Montagu tried to revive the executive prerogative in 1773 by refusing to approve Speaker Rawlins Lowndes. The Commons asserted the right to choose their speaker and declined to make a new election. Neither side would yield and the assembly was dissolved before it had organized. Montagu left the province a few weeks later, the newly elected assembly again chose Mr. Lowndes for speaker, and he was approved by Lieutenant-Governor Bull. ${ }^{2}$

The choice of clerk was likewise a subject of controversy. Like the speaker, he was, before 1732, elected by the house. But there was this difference: the governor had to approve the speaker, but he merely administered the state oaths to the clerk. In January, 1730, Mr. John Bayley, a member from Goose Creek, was

${ }^{1}$ Com. House Journals, Ms., XXII, 299-300.

${ }^{2}$ Ibid., XXXIX, Part II, 1-6; Public Records, Ms., XXXIII, 204-205. 
elected clerk and sent up to the president to take the necessary oaths. Middleton refused to qualify him, stating that he had good reasons, and that, if the house would choose another person more suitable, he would be glad to approve of him. His message was referred to a committee, which reported that they could find no precedents in their journals where a clerk had ever been sent to the governor for his approbation, and that the assembly had always chosen their own clerk and the governor had merely administered the oaths. To this Middleton replied that the governor always possessed the right of approbation, and that the only reason it had not been exercised was because acceptable persons had hitherto been chosen. He added that Bayley was the only person in the province who was personally obnoxious to him. The assembly adbered to their position and the dispute waxed warm. Middleton informed them that the clerk of the House of Commons in England was a patent officer and called attention to the fact that he was forbidden by the thirty-fifth article of the governor's instruction to allow the assembly any powers or privileges not possessed by the Commons in England. The house then sent up messages on various subjects, but Middleton informed them that he would return no answers until they receded from their choice of Bayley for clerk and presented another for his approval. A deadlock resulted and the assembly was soon after dissolved. ${ }^{1}$

Governor Robert Johnson arrived in the province in December, 1730, and his first assembly was

${ }^{1}$ Conncil Journals, Ifs., IV, 270-272, 274-280. 
convened on the 20th of the following month. Bayley was again chosen clerk, but the result had barely been announced when a message was received from the governor asking the house to recommend a suitable person for the place and saying that he would appoint him according to his instructions. They replied that they had already chosen their clerk and their messenger according to the usual custom, and that they would send them up to take the state oaths. Johnson retorted that the undoubted right of appointment was vested in the governor as His Majesty's representative; that he could not allow them to choose their clerk, though they might choose their messenger, as he believed that the House of Commons in England had this privilege; and, finally, that he intended to make the royal instructions the rule of his government. In answer to a demand of the house for his instructions on the subject, he sent down a copy of the thirty-fifth article of Governor Nicholson's instructions, and called attention to the fact that it had been made a law of the province by the eleventh section of the election act of 1721 . He used the same argument in regard to this instruction as had already been advanced by Middleton. The assembly denied the argument and declared that they would not recede from a point wherein their privileges were so much concerned.

Johnson now secured a personal audience with Bayley and offered him a clerk's commission. He went to the assembly for advice and they told him to act as he thought proper. He accepted the commission and His Excellency administered the state oaths. The house 
voted at once not to receive him as clerk by virtue of his commission. Bayley then resigned and surrendered his commission to the governor. The assembly elected Eleazar Allen to take his place. Johnson agreed, for the sake of harmony, to administer the oaths to Allen. He still maintained his right to appoint, however, and declared that he would submit the question to the king for final settlement.

On December 8, 1732, His Excellency informed the house that he had received a warrant from the king under the royal sign manual commanding him to appoint Isaac Amyand to be their clerk, and that he had commissioned him and administered the state oaths. A committee, appointed to consider the message, reyorted a number of precedents from Nicholson's administration to show that the right of the assembly to make their own choice had never been disputed. Johnson replied that he was determined to see the king's positive commands enforced, whatever the consequences might be. Seeing that they would be compelled to give up, the assembly began casting about for some method of retiring gracefully. One member produced a letter from New York which said that the governor of that province appointed the assembly's clerk, and another member announced that he had seen the like in the journals of the assemblies of the Jerseys. After thus looking up the precedents in true English fashion, they voted to receive Mr. Amyand as clerk. ${ }^{1}$

We have here recorded one of the very few victories

${ }_{1}$ Public Records, Extra, MIs., I, Part II, 608-616, 880, 882-883, 885886 . 
achieved by the prerogative party in their conflict with the people. During the remainder of the colonial period the clerk of the assembly was appointed by commission from the king or from his representative in the colony. After all, the victory was not so great as it might seem, for, being dependent upon the lower house for his salary, the clerk was really under their control.

The other officers of the assembly-messenger, deputy messenger, and cashier-were all chosen freely by the house itself without any interference from the executive.

The members of both houses served entirely without remuneration from the public purse. On December 11, 1746 , a bill was introduced into the assembly for the payment of members. The section providing for pay to councilors was first struck out and then the bill as a whole defeated by a vote of eighteen to eleven. ${ }^{1}$ Lieutenant-Governor Bull, writing to the Earl of Hillsborough in 1770, said that the members of the assembly disdained to take any pay for their services, though the members of the North Carolina and Virginia assemblies received eight or nine shillings sterling per day. ${ }^{2}$

The first attempt to change the election law of 1721 was made in 1745 . After a long dispute between the two houses, an act was passed, May 25, which slightly altered and amended the existing law. There were two questions on which the houses differed, one in regard to the extension of the franchise, and the other in regard to the manner of taking the qualification oath. The assembly wanted to extend the franchise and to allow

1 Com. House Journals, Ms., XXII, 239.

${ }^{2}$ Public Records, Ms., XXXII, 375. 
member's to take the oath according to their profession, and not on the Holy Evangelists, as was then required. The council desired to restrict the franchise still further and to continue the practice of taking the oath on the Evangelists. On May 16, the house bill was amended by the council in accordance with their views. Mr. Charles Pinckney entered his protest on the journals and made a strong plea in favor of civil equality for Protestant Dissenters. ${ }^{1} \quad$ The assembly adhered to their views and finally the matter was submitted to a conference committee. The committee adopted the council's views that the suffrage should be restricted to freeholders and that the old form of taking the oath should be retained. Strange to say, the lower house agreed to this settlement and the bill became a law. On the third reading in the council, Mr. Pinckney again entered his dissent and repeated his plea for civil and religious equality. ${ }^{2}$ Among the more important clauses of this act was one which declared ineligible for election any person holding an office or place of profit in the province from which he received a salary raised by the general assembly, another which provided for annual instead of triennial elections, and a final clause repealing the sections of the act of 1721 covering these subjects. ${ }^{3}$ An additional act of March 12, 1748, repealed the annual clause and made elections biennial. It also provided that persons who had scruples against taking the oath on the Evangelists might make a simple affirmation instead. ${ }^{4}$

I Council Journals (Upper House), Ms., XIII, 199-193.

2 Ibid., 195-196, 218-219, 221-222, 232, 236.

3 Statutes, III, 656-65s.

I Ibid., 692-693. 
These two acts were sent to England and in time came before the Board of Trade. They wrote to Governor Glen, June, 1748, that they had advised the king to repeal the law of 1745 becanse it limited the life of the assembly to one year, because it excluded persons holding places of trust or profit from sitting in the assembly, and, finally, because it repealed certain clauses of the law of 1721 and hence ought not to have been passed without a suspending clause, as required in the governor's instructions. ${ }^{1}$ The 1748 act was also disallowed by the king in council, October $31,1751 .^{2}$

The last effort at amendment was made in 1759 . An additional act to the law of 1721 was passed April 7 . Provision was again made for simple affirmation instead of an oath on the Evangelists, several clauses of the law of 1721 were repealed, and the 1748 law was declared repealed. ${ }^{3}$ This act was also disapproved by the king in council, because it repealed parts of the law of 1721 without good reasons being assigned and without a suspending clause, and also because it presumed to repeal the law of 1748 , which had already been disallowed by the crown. ${ }^{4}$ In spite of considerable complaint as to its looseness and deficiencies, the act of 1721 remained the election law of South Carolina until the Revolution.

1 Public Records, Ms., XXIII, 127-128.

${ }^{2}$ Com. House Journals, Ms., XXXV, 41.

3 Statutes, IV, 9S-101.

'Com. House Journals, Ms., XXXV, 41. 


\section{CHAPTER III}

\section{The Judiciary}

Is this chapter the following topics will be considered in the order named: judicial powers of the governor and council, common law courts, the circuit court act of 1769 , lower courts, admiralty court, and attempts to establish a court of exchequer.

The reader should always bear in mind the fact that the Lords Proprietors and their successor, the king, claimed the sole right of establishing and regulating courts of justice, a claim which the lower house of the general assembly stoutly denied and which, with more or less success, they attempted to nullify.

Judicial Powers of the Governor and Council

From the first settlement in 1670 practically all powers, legislative, executive, and judicial, were vested in the governor and council until a bench of judges was established in 1683 to attend to judicial business. The original common law jurisdiction, then taken away, was never restored. The following judicial powers, however, were still left or were conferred upon the governor and council at one time or another during the colonial period: they were authorized to sit as a high court of error to hear appeals in cases involving more than a certain amount $-£ 100$ sterling in $1721, £ 500$ in 1770 - though this jurisdiction was rarely, if ever, exer- 
cised $;^{1}$ they constituted a court of chancery ; and finally, the governor alone exercised the ecclesiastical jurisdiction of ordinary for granting marriage licenses, probate of wills, and administration of the estates of intestates.

A court of chancery was established early in the proprietary period. ${ }^{2}$ The unsuccessful attempt of the revolutionary party in 1720 to deprive the governor and council of their chancery jurisdiction will be considered in another connection. ${ }^{3}$ An act of September 9, 1721, reorganized the court and put it upon a statutory basis. The governor and a majority of the council were authorized to hold the court and to exercise the powers thereof in as full and ample a manner as any chancellor or court of chancery in America. They were to hold formal meetings four times a year on the first Thursday after the court of common pleas met in Charleston and sit from day to day until all business was disposed of. ${ }^{*}$ As a result of this, the legislative and executive duties of the council were often interfered with. So a law of 1732 enacted that the court should always be open, and, whenever any case came up for hearing, the governor could call together the council and dispose of it. ${ }^{5}$ The provision that a majority of the council was necessary to constitute a court also gave trouble, as many of the councilors were often absent

1 Public Records, Hs., VIII, 122, XXXII, 375.

2 Statutes, II, 19.

3 In the next topic on the common law courts.

Ibid., VII, 163-166.

5 Ibid., III, 324-325. This law was repealed in England because of certain other provisions not approved by the Board of Trade. The change in the time of meeting of the court was doubtless continued how. ever. 
from the province. To remedy this, an act of February 17,1747 , made a majority of those members actually in the province at any given time sufficient.' Though vested with the powers of His Majesty's High Court of Chancery in South Britain, this court proceeded only on the equity side, no officers whatever being appointed on the plea side to exercise what is called the ordinary jurisdiction of the court of chancery. Writs of scire facias, for example, were nerer issued. ${ }^{2}$

\section{Common Law Courts}

On January 2, 1683, in accordance with an instruction from the proprietors, Governor Morton and the other proprietary deputies issued commissions to Robert Gibbes, sheriff, and Stephen Bull, Edward Middleton, Richard Conant, and Robert Daniel, assistant justices of Berkeley county. They were to attend to the judicial business of the entire province until the growth of population warranted the establishment of courts in the other counties. ${ }^{3}$ These officials were all laymen as there were no trained lawyers in the province at this time. The sheriff, like his old English predecessors, was a judicial as well as an executive officer, being both chief justice and sheriff of the court. ${ }^{4}$ An appellate jurisdiction was still reserved to the governor and council.

I Statutes, VII, 191-193.

2 Council Journals, IIs., X, 107-10s. For the distinction between the ordinary and extraordinary jurisdiction of the court of chancery, see Spence, Equity Jurisdiction, I, 336-337; Kerly, History of Equity, 49-50, 55-56.

${ }^{3}$ Public Records, Ms., I, 139-140; Council Journals, Ms., I, 63-64.

4 Rivers, Sketch of the Hist. of S. Car., 434. 
As the records for these early years are rather fragmentary, it is difficult to follow the history of this court. The assistant judges probably dropped out of the system in a short time, at least by 1698, one chief judge being sufficient for the needs of the province. He was, as we have seen, appointed by the governor and council as sheriff or judge of Berkeley county and was given only a temporary jurisdiction over the rest of the province until separate county courts were established. The first regular chief justice of the whole province was Mr. Edmund Bohun, commissioned by the Lords Proprietors, May 22, 1698, at a salary of $£ 60$ a year. ${ }^{1}$ Between 1698 and 1719 the office was held by Bohun, James Moore, Nicholas Trott, Robert Gibbes, and Nicholas Trott, in the order named. ${ }^{2}$

It is difficult to fix upon an exact date for the origin of the two common law courts. The judges appointed in 1683 heard both civil and criminal cases, probably holding separate sessions for each. As early as 1692, mention is made of the court of pleas, and in 1701 an act was passed providing that the court of general sessions of the peace and general gaol delivery should be held twice a year, both references implying that the courts were already in existence under these names. ${ }^{3}$

These courts doubtless followed the common law procedure, although the common law was not formally adopted in the province by statute until 1712. An act, ratified December 12 of that year, put in force one

IS. Car. Hist. Soc. Col., I, 145.

2 MeCrady, S. Car. under Prop. Govt., 721.

${ }^{3}$ Rivers, Sketch of the Hist. of S. Car., Appendix, 434 ; Statutes, II, 166-167. 
hundred and sixty-seven selected English statutes, extending from Magna Charta to the eighth of Anne, chapter 17, and declared that the entire common law of England with certain restrictions and limitations was to be in force. Courts of record in the province were to have all the powers and privileges conferred upon the king's courts by the above mentioned statutes. ${ }^{1}$

From this time until the fall of the proprietary government practically the entire judicial business of the province was in the hands of one man. Chief Justice Nicholas Trott was sole judge of the courts of common pleas and general sessions, judge of the vice-admiralty court after 1716, and, as a councilor, a member of the court of chancery and of the highest appellate court in the province. His abuse of these vast powers was one of the chief causes of the revolution of 1719. Consequently, when the revolutionary party came into power, one of their first acts was to pass a law for regulating the courts of justice, ratified February 12, 1720. ${ }^{2}$ This is the first statute which deals to any extent with the constitution and procedure of the courts. Prerious to this time, their establishment and regulation had been regarded as essentially a prerogative of the proprietors. The common law courts and the court of chancery were all considered and the governor and council were practically shorn of judicial powers.

The common law courts were to consist of a chief jus-

1 Statutes, II, 401-508.

2 Ibid., III, 99. Title only. The original act is now lost, but a copy made in 1749 is preserved in the British Public Record Office. Through the kindness of the officials of that office $I$ have been able to secure a copy. 
tice and not exceeding five assistants, commissioned by the crown, though vacancies were to be filled by the governor and council until His Majesty's pleasure could be known. Inasmuch as Trott had been removed and there had been no assistant judges since 1698 at the latest, the entire bench had to be filled temporarily by the governor and council. Richard Allein was appointed chief justice, with perhaps five assistants. On June 2, 1721, four days after Governor Nicholson arrived in the province, Allein was succeeded by Francis Yonge, and a new bench of assistants was appointed, consisting of Charles Hill, John Fenwicke, Samuel Eveleigh, William Dry, and Alexander Parris. ${ }^{1}$

The ninth section stated that governors had arbitrarily committed men to prison because of private grudges, and, having the power to remove judges and revoke the licenses of lawyers, had disregarded the $h a$ beas corpus act. Hence it was enacted that no judge could be suspended or removed by the governor on any pretence whatsoever, and licenses to lawyers were to be issued and revoked only by the judges or chancellor under whom they pleaded.

The governor and council as a court of chancery were done away with and they were authorized to appoint a chancellor, who was to hold a court of chancery, with the same powers and jurisdiction exercised by other similar courts in America, except in the matter of appeals and writs of error. He could be suspended or removed only by the king.

Section four called attention to the abuse of appeal-

1 Public Records, Extra, Us., I, Part I, 15. 
ing from the decisions of the common law courts to a comrt of equity or to the governor in council, and from the decrees of the chancery court to the governor in council. It was enacted that all writs of error and appeals and all injunctions or orders of restraint issued by the governor or governor in council for re-examining suits or staying proceedings should be ipso facto null and roid. If the defendant had an equitable remedy in view, he was to seek the same in a court of equity before the chancellor and not before the governor in council, and, except in extraordinary cases, must do so before a verdict in law was reached. Injunctions for staying suits were not to be granted of course or by surprise, but a bill had to be filed and timely notice given to the other party in writing. Furthermore, the complainant was required to take oath that he believed the allegations set forth in his bill to be true.

The court was to be always open for the dispatch of such cases, while full and solemn hearings were to be held six times a year, beginning on the first Tuesdays in January, April, June, July, September, and November. The registrar and master in chancery, though appointed by the governor and council, could, like the judges and chancellor, be removed only by His Majesty.

Perhaps the most significant encroachment upon the royal prerogative is to be found in section seven, which provided that the governor, council, and assembly should constitute a court to hear appeals from the common law and chancery courts in cases involving more than $\$ 100$ sterling. Appeal had to be made within fourteen days after the judgment or decree was rendered, if the assem- 
bly were in session; otherwise, within fourteen days after the assembly met. Where more than $£ 500$ was involved, appeals might be made to the king, provided ample security were given to meet the expenses of the case.

This law, as we have seen, was passed just after the overthrow of the proprietary govermment and while the people were still in a frenzy over the arbitrary conduct of Judge Trott. Its most radical features were buried beneath the wave of loyalty which followed Governor Nicholson's arrival. The governor and council regained their chancery and appellate jurisdictions with undiminished powers. True, a bench of assistant judges was appointed, but it is at least doubtful whether their commissions are based upon the law. The question of tenure does not seem to have arisen until 1749. In that year an assistant judge denied the right of Governor Glen to suspend him from office and cited this act in defense of his position. Glen laid the whole matter before the Board of Trade together with a copy of the law. ${ }^{1}$ After hearing a report from their special counsel, Mr. Matthew Lamb, the board gave an opinion, October 26,1750 , that the law of 1720 was null and void, having been passed by a revolutionary body and never ratified by either the proprietors or the crown. ${ }^{2}$

So far as they were regulated by statute at all, rather than by instructions from the crown, the courts proceeded until 1731 under this law and another of $1727,{ }^{3}$

1 This is the copy still preserved in the Public Record Office.

2 Public Records, Ms., XXIII, 432-434, XXIV, 4-5, 34-35, 163.

${ }^{3}$ Statutes, III, 273. Title only. 
which is now lost. The act of 1727 was repealed by the queen in council, July 21, 1732, because it altered the first process in civil actions from a summons left at a man's house to a capias, which had to be personally served. The merchants complained that the frequent absence of the inhabitants in their trade with the Indians and the distance that they lived from Charleston made it very inconvenient to serve personal summons and hence difficult for them to collect their debts. ${ }^{1}$

During the period of anarchy from 1727 to 1731 the jury list was exhausted and the courts had to be closed.2 One of the first laws passed after Governor Johnson's arrival was "An Act confirming and establishing the ancient and approved method of drawing Juries by ballot, in this province, and for the better administration of justice in criminal causes, and for appointing of Special Courts for the trial of the causes of transient persons, declaring the power of the Provost Marshal, for allowing the proof of deeds beyond the seas as evidence, and for repealing the several Acts of the General Assembly therein mentioned," ratified August 20, 1731. All previous acts on the subject were repealed and this remained the jury law until after the Revolution.

Three jury lists were made up every three years. From one list, composed of those who paid more than five pounds currency in taxes, were drawn the grand jurors; from another, composed of those who paid more than twenty shillings, the petit jurors; and from the

1 Public Records, Ms., XIV, 279-280, XV, 139-140.

2 Ibid., XV, 37.

3 Statutes, III, $274-287$. 
third, composed of the taxpayers of Charleston, jurors for special meetings of the court of common pleas and for inquests of various kinds. The order of service in each list was determined by lot. Members of the council and assembly, judges and officers of the courts of justice, and all persons excepted by the laws of Great Britain were exempted from jury duty.

Section thirty of this law enacted that "henceforth there shall be erected, established, and holden in Charleston, in this province, a court of record by the name and stile of the Court of General Sessions of the Peace, Oyer and Terminer, Assize and General Gaol Delivery, and the said court shall always hereafter be holden before the Chief Justice of this Province for the time being, and two or more assistant judges, to be commissioned for that purpose by His Majesty, his heirs or successors, or by the Governor and Commander in Chief of this Province for the time being." This court was to have all the powers, jurisdictions, and authorities possessed by the courts of king's bench, assizes, oyer and terminer, or any court of general and quarter sessions of the peace in Great Britain. Two sessions were to be held each year, in March and October. ${ }^{1}$ In the absence of the assistant judges, the chief justice was empowered to hold court the same as though they were present.

One very important innovation in criminal procedure was made by this law. It seems the most natural thing in the world to us that a criminal should have the benefit of counsel. At that time, however, such a thing was

1 The number of meetings was increased to three per annum in 1767 . Statutes, VII, 194-197. 
almost unheard of anywhere. It was not until 1836 that prisoners in felony cases were allowed counsel in England. ${ }^{1} \quad$ This South Carolina statute of 1731, however, provided that every person accused and indicted for high treason, petit treason, murder, felony, or other capital offense whatsoever should have a copy of the indictment against him, be allowed to make his defense through counsel learned in the law, and produce proof by lawful witness or witnesses. On the request of the prisoner, the judge of the court was required to assign one or two persons to defend him. The reason advanced for this was that the judges of the several courts, who ought to assist prisoners in matter's of law, could not be presumed to have as great knowledge and experience as the judges at Westminster. ${ }^{2}$ In a letter to the Earl of Hillsborough in 1770, Lieutenant-Governor Bull stated that counsel was allowed to defend criminals not only in matters of law but generally. ${ }^{3}$

An act of February 26, 1732, provided that the court of common pleas should meet as usual four times a year on the second Tuesdays in February, May, August, and November. Two or more assistant judges were to be appointed and commissioned by the king or his governor. The chief justice was empowered to act in their

1 Statutes at Large, 6 and $i$ William IV, chap. 114. Laws of 1695 and 1747 allowed persons charged with treason the benefit of counsel under certain restrictions. Counsel was also permitted in misdemeanor eases. In this connection see Bishop, New Criminal Procedure, Fourth Ed., I, 14, 296-298; Sharswood, Blackstone, II, 354-356; Rex vs. White, 3 Campbell, 98; Rcx rs. Perkins, 1 Ryan and Moody, 166; 7 William III, chap. 3 ; 20 George II, chap. 30.

2 Statutes, III, 286.

${ }^{3}$ Public Records, Hs., XXXII, 3テ-37s. 
absence, and any one of them could in his absence adjourn court from day to day until he arrived. ${ }^{1}$ The chief justice had sat alone since Governor Johnson's arrival in the province, no assistants having been appointed under the act of $1731 .^{2}$

By an act of April 9, 1734, the assistants were given an equal voice with the chief justice. In the event of his absence or withdrawal from the court on the day appointed for the meeting, any three or more of them were authorized to sit and hold court just as though he were present. ${ }^{3}$

The reasons for this attack on the power of the chief justice are to be found in a study of the land system. In that connection something has already been said of the arrest of Dr. Thomas Cooper and of how Chief Justice Wright incurred the anger of the land speculators by his able defense of the privileges of the writ of habeas corpus. It was these speculators who secured the passage of the above mentioned act and induced Governor Johnson to remove Assistant Judge Cooper and appoint Thomas Dale in his place. Thomas Lamboll, another friend of the governor's was appointed to succeed Daniel Green, who had gone to England for his health. ${ }^{4}$

1 Statutes, III, 323-326. On account of the summer heat, a law of 1734 changed the August and November meetings to October and December respectively. Ibid., VII, 186.

Public Records, $M s$., XVII, 268-269. It must be remembered that both of the common law courts were presided over by the same set of judges.

${ }^{3}$ Statutes, VII, 184-189.

4 Public Records, IIs., XVI, 309-311, 328-329. 
Wright and his friends petitioned the king to disallow both the act of 1732 and that of 1734 , alleging that, as the subordinate justices could override the chief, the judiciary of the province was at the mercy of the governor and assembly. ${ }^{1}$ The whole question was argued before the Board of Trade and the Lords of the Treasury. Both laws were repealed by the king, August 14, 1735 , on the ground that they empowered and required the governor to appoint assistant judges, which was a manifest encroachment upon the royal prerogative. An additional instruction was sent ont to Lieutenant-Governor Broughton saying that, as it was best for the welfare of the province that there should be assistant judges, the king was pleased to direct him to appoint two of them in each court in the province with equal powers in the dispensation of justice with the chief justice, in the same manner as was practiced by the puisne judges in similar courts in England. ${ }^{2}$ An act of 1740 empowered a majority of the assistant justices to hold the court of general sessions and try all criminal cases during the absence of the chief justice the same as when he was present. ${ }^{3}$

The court of common pleas was finally placed on a statutory basis by an act of March 5, 1737, just as the court of general sessions had been by the act of 1731 . The court was to meet four times a year, in February, May, August, and November and was to exercise all of

1 Public Records, Ys., XVI, 309-312, XVII, 268-270.

2 Ibid., 366-367; Com. House Journals, Ms., X, 112.

3 Statutes, III, 555. 
the powers of the court of common pleas at Westminster.'

The two common law courts continned as thus organized until the Revolution, though in 1772 their jurisdiction was limited to a single district of which Charleston was the center. The chief justice, as a rule, was the only trained lawyer on the bench. ${ }^{2}$ He attended to nearly all the business of the court, and during most of the time there were no assistant judges in commission at all. Thus, Robert Pringle was the only assistant when the struggle over the use of stamped paper in the courts began in 1766. It was through LieutenantGovernor Bull's appointment of Rawlins Lowades, Benjamin Smith and Daniel Doyley to seats on the bench that the people were able to outwit Chief Justice Skinner. ${ }^{3}$

Before taking up the consideration of the circuit court acts of 1768 and 1769, the reader's attention should be called to a very important document in the judicial history of South Carolina. This is a letter of February 3, 1742, from Chief Justice Whitaker to Henry McCulloh, His Majesty's superintendent of the quit rents, in response to a request for an opinion on the jurisdiction of the law courts. ${ }^{4}$ After declaring that the courts of chancery, general sessions, and common pleas had been established by acts of the general

1 Statutes, VII, 189-191.

${ }^{2}$ Charles Skinner, appointed chief justice in 1762 , seems to have had no legal training whatever, but he was an exception.

3For a fuller discussion of this subject see the final chapter, "The Downfall of Royal Government."

- Council Journals, Ms., X, 102-112. 
assembly in derogation of His Majesty's royal prerogative, 'he proceeded to discuss their powers and jurisdiction, giving some very valuable information, especially in regard to the chancery court. By all odds the most important part of the letter, however, is that in which he suggests that the law courts should pass upon the constitutionality of acts of the general assembly. His argument was as follows: All acts of the general assembly were made by virtue of authority derived from the crown and must not be contrary to the king's instructions and the prerogative of the crown or repugnant to the laws of England. But, many such laws had been passed in all the colonies. "The question is whether these laws are roid when they are first made, or only voidable by His Majesty's disallowance and may be put in practice till His Majesty's pleasure shall be signified that the same are repealed. And whether the Judges of the Courts when they are given in Evidence or pleaded in Cases depending before them, ought to judge them ipso facto void, or only voidable and so to be put in practice till they are repealed by His Majesty." 2 This is, I believe, the earliest suggestion ever made that a law court should declare an act of the legislature void because contrary to a written constitution. The king in council, to be sure, had often repealed colonial statutes on the ground that they were repugnant to the laws of England, but the exercise of such a func-

1 Established in the sense that their constitution and powers were regulated by the acts of 1721,1731 and 1737 , though all three existed long before the earliest of these dates.

${ }^{2}$ Council Journals, 11 s., $\mathrm{X}, 110$. 
tion was clearly legislative rather than judicial in character. $^{1}$

\section{The Circuit Court Act of 1769}

The two common law courts at Charleston, together with the courts of justices of the peace for the trial of petty cases, amply served the needs of the province during the earlier years of its existence. As the settlements gradually extended further and further away from the coast, however, it became burdensome for the people to travel one hundred and fifty or two hundred miles to Charleston to attend court. The matter became still more serious when the Scotch-Irish, after Braddock's defeat in 1755 , poured into the upper part of the province from the colonies to the northward. They were a law-abiding people and had little need for courts of justice, until the peace of 1763 and the consequent disbanding of the British and French armies let loose a hoard of worthless vagabonds among them. ${ }^{2}$ The government at Charleston was helpless to preserve order, especially as the settlers refused to go down there for jury or witness service. The better class of frontiersmen demanded that courts should be established in their midst and determined to take the law into their own hands until this was done. A kind of law and order league, known as the Regulators, was organized for the purpose of inflicting summary punishment on criminals of all descriptions. The govern-

In this connection see Brinton Coxe, Judicial Pouer and Uneonstitutional Legislation, Chap. XX, espeeially the sections dealing with the ease of Winthrop vs. Lechmere, 208-213, 370-382.

$2 \mathrm{MeCrady}$, S. Car. under Royal Govemment, 312, 624-625. 
ment finally realized the seriousness of the situation and took steps to provide a system of circuit courts for the entire province.

The principal obstacle to this course was that it would lessen the fees of the provost marshal of the province. The patent for this office had been held since 1759 by Richard Cumberland, the English dramatist, who exercised his official duties through deputies and received a large share of the fiuancial returns. Mr. Roger Pinckney, his deputy in the province, informed a committee of the assembly in December, 1766, that Cumberland was inclined to sell his patent. The committee of correspondence was ordered to write to $\mathrm{Mr}$. Garth, the colony agent in England, and authorize him to treat with Cumberland for any sum not exceeding $£ 4,000$ sterling. ${ }^{1}$ While anarchy and lynch law were becoming the order of the day in upper South Carolina, Garth and Cumberland were in England higgling over the compensation to be paid for the loss of the office of provost marshal. Cumberland refused to sell for less than $£ 5,000$ sterling. Finally, on November 11, 1767, the assembly resolved to pay this sum and authorized Garth to close the bargain. $^{2}$

"An Act for establishing Courts, building Gaols, and appointing Sheriffs and other officers for the more convenient administration of Justice in this Province" soon passed the council and assembly and was ratified by the governor, April 12, 1768. The entire province was di-

1 Com. House Journals, Ms., XXXVII, 238-239.

2 Ibid., 469, 474. See Schaper, Sectionalism and Representation in S. Car., Annual Report of Amer. Hist. Association, 1900, Vol. I, 337-338. 
vided into seven judicial districts, each named for the town in which the court was to meet: Charleston, Beaufort, Orangeburgh, Georgetown, Camden, Cheraws, and Ninety-Six. ${ }^{1} \quad$ The courts of general sessions and common pleas were still to sit at Charleston three and four times per annum respectively, but their jurisdiction was restricted to the Charleston district. Circuits for the trials of all cases, civil and criminal, were to be held in the other districts in April and November of each year. The chief justice of the province and the assistant justices of the common law courts at Charleston were to be judges in all the courts. They were given power to decide without jury disputes involving less than twenty pounds sterling, except when land titles came into question, when both parties demanded a jury, or when one party demanded it and paid the expenses. The office of provost marshal was abolished and provision made for a sheriff in each district, who was to be appointed by the governor from a list of three selected by the judges of the court of common pleas. Whenever the king should be pleased to appoint judges during good behavior they were to receive the following salaries: the chief justice $£ 500$ sterling, and the assistant justices $£ 300$ sterling each per annum; the attorney-general and the clerk of the common pleas then in office were allowed $£ 200$ and $£ 300$ respectively. The act was not to go into effect until approved by the crown, nor were the courts to be opened for business until all the court houses and gaols had been completed. ${ }^{2}$

'A map showing these divisions will be found in Carroll, Hist. Col. of S. Car., I, frontispiece.

${ }^{2}$ Statutes, VII, $197-205$. 
The necessity of waiting for the king's approbation of the law before putting it into operation gave rise to another long delay. The Board of Trade referred it to their special counsel, Mr. Mattlew Lamb, who brought up a number of objections. First, he criticised the clause which allowed judges in the circuit courts to determine summarily cases involving not more than twenty pounds sterling. This sum was too large, he declared, objections having been made in other colonies when a much lower limit was fixed. Secondly, the abolition of an office held under patent from the crown was an encroachment on the royal prerogative. ${ }^{1}$ Thirdly, the clause providing salaries for the judges whenever the king should be pleased to appoint them during good behavior was derogatory to His Majesty's dignity. Fourthly, the salaries provided for the attorney-general and the clerk were only for the present officers, and did not extend to the future. ${ }^{2}$

The Lords of Trade in their report to the king, made September 15, 1768, disregarded Lamb's first two objections, laid considerable stress on the third and fourth, and added a fifth, namely, that the method of appointing sheriffs took away the discretionary power of the governor and hence of the crown. ${ }^{3}$ The Lords of the Committee of the Privy Council agreed entirely with the objections of the Board of Trade, but the two main

I Lamb did not seem to know that the king, through the Earl of Shelburne, had already authorized the abolition of the office of provost marshal, provided proper compensation were made. Public Records, $M$ s., XXXII, 46.

2 Ibid., 43-44.

: Ibid., 44-50. 
objections, those concerning the tenure of judges and the appointment of sheriffs, seemed still stronger to them "insomuch that they considered the first as indecent and disrespectful to His Majesty and the other as altogether inadmissible." His Majesty in council issued an order, October 7, 1768, rejecting the bill and forbidding the governor to give his assent to any similar act in the future until the two objections just noticed were obviated. ${ }^{1}$

Meanwhile the disturbances in the back settlements were increasing. Lieutenant-Governor Bull issued a proclamation, August 15, 1768, calling on all law-abiding eitizens to help put down the riots. ${ }^{2}$ The Regulators and their opponents, the Scovilites, threatened for a time to plunge the upper country into a bloody civil war. ${ }^{3}$

The assembly was dissolved November 19, 1768, because of a quarrel with Governor Montagu over the Massachusetts circular letter of February 11. Although an election was held shortly afterwards, the new assembly was not allowed to meet for business until June 26 of the following year. Montagu had just returned from an extensive tour of the back country. Consequently, in his opening speech, he dwelt upon the grievous condition of affairs in that section of the province, due to the lack of courts, and urged the assembly to take some steps to remedy the matter. At the same time he informed them that the circuit court act had been disap-

1 Public Records, 11 s., XXXII, 51-53.

2 S. Car. Gazette, No. 1715, August 15, 1768.

- For an account of these troubles see McCrady, $s$. Car. under Royal Govt., 594-595, 634-638. 
proved in England and laid before them the report of the Board of Trade.

Messrs. Lynch, Lowndes, Powell, Gaillard, Rutledge, Gadsden, and Kershaw, who had been appointed a committee to consider the question, reported, on July 4 , that a bill should be brought in similar to the other, but without the objectionable stipulation in regard to judges holding office during good behavior. ${ }^{2}$ Such a measure was at once passed through both houses and sent up to the governor. He refused to ratify it on the ground that only one of the objections of the Board of Trade had been disposed of. The assembly maintained that they had obviated the only objection upon which the board had laid any stress, but Governor Montagu stood firm in his opposition. A new bill was introduced, enacted into a law on July 29, and was carried to England by the governor himself. ${ }^{3} \quad$ This act is not to be found at all in Cooper's collection of the statutes, though a mutilated form of it is given in Grimké. It was, however, identical with the act of the preceding year, except in the clauses relating to the tenure of judges, the salaries of the clerk of the crown and the attorney-general, and the appointment of sheriffs.

As soon as Governor Montagu arrived in London, he laid the act before the Board of Trade. A favorable report was received, and the king in council signified his approval on November 29. Lieutenant-Governor Bull

${ }^{1}$ Com. House Journals, Ms., XXXVIII, 11.

2 Ibid., 25, 29.

${ }^{3}$ Ibid., 29, 74-75, 76-78, 81, 93.

- Grimké, Public Laus of S. Car., 268-273. 
was notified and was requested to send over a list of persons suitable to act as assistant judges. ${ }^{1}$ The evident intention was that the assistants should be selected from among the colonists, but, if so, the idea was soon abandoned. We cannot be sure whether this change of policy was due to the refusal of the South Carolina lawyers to serve, to the unwillingness of the home government to trust them, or to the pressure brought to bear by the spoilsmen in London. Perhaps all three causes had their effect. At any rate, the entire bench was appointed and sent out from England. It consisted at first of Thomas Knox Gordon, chief justice, and Edward Savage, Charles Matthews Coslett, John Murray, and John Fewtrell, assistant justices." These men formed an addition to the ranks of the needy placemen, whose increasing numbers had already begun to arouse the animosity and weaken the loyalty of the people. South Carolina had some experience in carpetbag government a century before the days of Reconstruction.

The act of 1768 contained a clause, which was repeated in that of 1769 , providing that the law was not to go into operation until all the court-houses and gaols in the province were completed, although no appropriation for expenses or details in regard to the matter were inserted in either act. Bull informed the assembly, February 21, 1770, of His Majesty's approval of the law, and urged them to take immediate

1 Public Records, Ms., XXXII, 70-71, 113-11i, 131.

2 Ibid., XXXIII, 20-21, 40-41, 116. 
steps for erecting the necessary buildings. ${ }^{1}$ A committee report of March 7, 1770, presented plans for court-houses in the country districts to be built of wood, for gaols to be built of brick at Georgetown, Port Royal, and Orangeburgh, and of wood in the other districts, and for a brick gaol at Charleston. To meet the expenses of this work the issue of $£ 50,000$ in paper money orders was recommended. The liouse agreed to the report with an amendment authorizing the issue of $£ 70,000$ instead of $£ 50,000$. $^{2}$ Accordingly, an act was passed, April 7, 1770, for issuing this amount in public orders, to be redeemed within five years from the funds arising under the general duty law. ${ }^{3}$

The work on the new buildings proceeded so slowly that the assistant judges complained to Lord Hillsborough, January 23, 1772 , that it was being delayed on purpose to keep them out of their salaries, some of the popular leaders declaring that, as the law was not to be put into force until all the court-houses and gaols were completed, the salaries of the judges could not begin until that time. ${ }^{4}$ In consequence of orders from the home government, the province was compelled to pay the judges and attorney-general their salaries in

${ }^{1}$ Com. House Journals, Ms., XXXVIII, 273-275.

2 Ibid., 305, 311-312.

statutes, IV, 323-326. This act was disallowed by the king in council, January 15, 1772, on the ground that the clause which made the orders legal tender in payment of all duties and taxes was contrary to the 4th George III, chap. 34. Public Records, Ms., XXXIII, 111-112. As the orders had already been issued and the work was far advanced, this repeal was disregarded.

- Public Rccords, Ms., XXXIII, 113-1I6. 
full from February 19, 1770, the date on which Lieutenant-Governor Bull issued his proclamation announcing the confirmation by the king of the act relating to circuit courts. ${ }^{1}$

A proclamation of May 19, 1772, announced that all of the court-houses and gaols had been completed and that the courts were to be opened at once. ${ }^{2}$ The six districts outside of Charleston were divided into two circuits, the southern including Orangeburgh, NinetySix, and Beaufort, and the northern including Camden, Cheraws, and Georgetown. ${ }^{3}$

\section{Lower Courts}

There have been justices of the peace in South Carolina almost from the day on which the first settlement was made. In colonial times they were appointed under a general commission issued by the governor and council, and held during His Majesty's pleasure. A new commission, dated March 26, 1737, may be taken as a type. It appointed one hundred and one justices for Berkeley county, including the members of the council, members of the assembly residing in the county, the chief justice and assistant justices, various officials such as the secretary, attorney-general and master in chancery, and a number of other prominent men. Twenty were appointed for Colleton county, twentyfour for Craven, thirteen for Granville, and two for New Windsor (Fort Moore) and the parts adjacent. ${ }^{4}$

1 Public Records, IIs., XXXIr, 137-138; Com. House .Journals, Ms., XXXIX, Part II, 69.

${ }^{2}$ Com. House Journals, Hs., XXXIX, Part II, 69.

3 S. Car. Gazette, No. 2035, Mareh 27, 1775.

4 Ibid., No. 166, April 2, 1737. 
Other similar commissions were issued from time to time and the number of justices increased as the province became more thickly settled.

Their powers and duties were determined by English tradition, provincial statutes, and instructions from the governor and council. One or more justices were empowered to hear and decide in a summary manner all actions for debts not exceeding a certain amount, forty shillings sterling until 1727, and twenty pounds currency, equal to about fifty-six shillings, after that date. They committed men to prison and released them on bail, issued warrants of the peace and warrants of hue and cry, administered oaths, took depositions, attested the returns of appraisements, and issued certificates for the heads of wild beasts, so that the owner could get his bounty. They also acted as toll masters, that is, took charge of stray live stock, advertised for the owners, and, if they were unclaimed, sold them for the benefit of the public and the informers. ${ }^{2}$ One justice and three freeholders sat as a court to determine the amount of damages arising from an abuse of riparian rights. ${ }^{3}$

An attempt was made in 1747 to establish courts for the trial of small debt cases similar to the courts of conscience or request in England, which Maitland defines as "a body of unpaid commissioners, of local tradesmen or the like, empowered to adjudicate without jury upon very small debts."' By an act of June 13,

1 Statutes, II, 27-29, 47-49, 74-76, 598, III, 131-132, 268-269.

2 Ibid., II, 331-332, III, 603-606.

3 Ibid., III, 609.

+ Justice and Police, 23. 
1747, two justices and three freeholders, or a majority of them, were given power to determine in all actions for debt in which the amount in dispute exceeded twenty and was less than seventy-five pounds currency." This law promised to give relief to the settlers in the remote parts of the province, who were put to the trouble and expense of going down to Charleston every time they wished to sue for a debt exceeding twenty pounds currency. It met with opposition in England, however, mainly because the fees of the provost marshal were reduced. As usual when there was a conflict between the interests of the people and the interests of a crown official, the latter came off victorious and the law was disallowed. ${ }^{2}$

Special courts for the trial of negro slaves were provided for by an act of 1690 . Any justice of the peace, on complaint being made to him, was authorized to issue a warrant for the arrest of the offending slave. He was then to call in another justice of the same county, and the two of them summoned three freeholders to complete the court, and appointed a day for the trial. Trial was without jury and the decision was final. ${ }^{3}$ The punishment meted out consisted in whipping, branding, cutting off the ears, or the infliction of the death penalty, according to the severity and frequency of the offense. ${ }^{4}$

1 Statutes, III, 701. Title only.

${ }^{2}$ Public Records, Ms., XXIII, 5-7, 184, 185. Counsellor Lamb, it is true, advanced other objections in his report to the Board of Trade and declared that the private advantage of crown officials should not be allowed to interfere with the public welfare, but there can be no doubt that it did so interfere in this case as in many others. Chalmers, Colonial Opinions, 476-479.

${ }^{3}$ Statutes, VII, 345-347.

4 Ibid., 355, 374. 
With some changes in detail this method of trial continued in South Carolina as long as slavery existed. By an act of June 7,1712 , the value of all slaves executed according to law was to be fixed by a disinterested board of appraisers and compensation made to the owners out of the public treasury. ${ }^{1}$ This proved too heavy a burden on the public; so a law was passed in 1717 providing for a special tax upon the slaveholder's of a parish whenerer a negro was executed within its limits. ${ }^{2}$ Such a localization of expense probably induced the courts to be too lenient in their treatment of slave criminals. At all events, the old plan of compensation from the public treasury was restored after the Stono insurrection of $1739 .^{3}$ The presence of the entire court was required in capital cases, though the vote of one justice and two freeholders or of one freeholder and two justices was sufficient to convict. For minor offenses one justice and two freeholders were sufficient, and the concurrence of the justice and one freeholder enough to convict."

The slave code adopted in 1740 remained substantially unchanged until the Civil War. It provided that the court for the trial of capital offenses should consist of two justices and not more than five nor less than three freeholders. The most important innovation was the

1 Statutes, VII, 358.

2 Ibid., 369.

3 Ibid., 403. A temporary change in form, but not in principle was introduced in 1722 as a part of the attempt to establish the county system of local government. The county and the judicial precinct established by the law of 1721 were substituted for the parish. Ibid., 377.

Ibid., 366, 384, 400-401. 
bringing of free negroes under the jurisdiction of the court. ${ }^{1}$

Next in importance among the lower courts was that presided over by the coroner. Mention is made of such an official in Charleston as early as $1685,{ }^{2}$ but no law dealing with the fees and duties of the office was passed until 1706. There were at that time several coroners in the province. Their principal duty, then, as now, was to hold inquests over the bodies of persons who met with sudden or violent deaths. Each coroner was required to make returns of all inquisitions taken before him to the next court of general sessions, and, upon the finding of a death by murder or homicide, to inform one or more of the justices of the peace for his county, so that the guilty party might be arrested and held for trial. ${ }^{3}$ They were appointed by the governor, except for a short period succeeding the year 1723 , when the power of appointment was vested in the justices of the newlycreated county and precinct courts. ${ }^{4}$

Mention of these courts suggests a brief consideration of the first serious attempt to furnish judicial facilities for the back settlers. "An Act for establishing County and Precinct Courts," passed September 20, 1721, provided for five courts of pleas, assize, and gaol delivery-one at Wassamsaw, in Berkeley county, for the parishes of St. James's Goose Creek, St. George's and St. John's ; another at Echaw, in the parish of St. James's Santee, for Craven county; a third at Willtown 231.

1 Statutes, VII, 397-417, 402; McCrady, S. Car. under Royal Govt.,

2 Statutes, II, 6.

Ibid., 269-273.

Ibid., VII, 181.

10 
for Colleton county ; ${ }^{1}$ a fourth at Beaufort for Granville county; and a fifth at or near the plantation of Louis Dutarque in Berkeley county, to be called Wando precinct, for the parishes of St. Thomas's, St. Dennis's, and Christ Church. Actions in Berkeley county outside of Wassamsaw and Wando precincts were to be tried at the general court in Charleston. The courts were modeled after the English courts of quarter sessions. Five judges, commissioned by the governor from among the magistrates of the respective counties and precincts, were placed over each court. Three constituted a quorum for business. Courts were to be held in each precinct or county four times a year and were to have jurisdiction over all criminal cases not extending to life or limb and civil cases involving not more than one hundred pounds sterling. Under certain restrictions, appeals in civil cases were allowed to the general court at Charleston. Like our boards of county commissioners and supervisors, the judges constituted the county or precinct authority and attended to a number of administrative duties. Thus they were empowered to punish obstinate servants, to license taverns, to bring suit for legacies left for public purposes, to take charge of the estates of orphans, to inspect the accounts of church wardens and overseers of the poor, to lay out and repair roads, to build court houses and gaols, and to levy taxes to pay for the same. ${ }^{2}$

Considerable hardship was caused by the provision in this law for the trial of cases either in the county or pre-

1 The people on John's Island were subject to the courts at Charleston.

s Statutes, II, 166-176. 
cinct in which the defendant lived or in that in which he was arrested. Settlers on going down to Charleston to market were often seized on debt charges and thrown into prison. The evil was remedied by an additional act of February 23, 1723, requiring that the trial should be held in the defendant's own county or precinct. Semi-annual were substituted for quarterly sessions of the court, as it was found that all business could be attended to in the two meetings. ${ }^{2}$

The system was a trifle too elaborate for the existing needs of the province. It was suggested in a committee report of November 5, 1725, that three courts were amply sufficient and a recommendation was made that the plaintiff should be allowed to take out his writ either from his own precinct court or from the general court at Charleston. ${ }^{2}$ By 1731 several of these courts had fallen into disuse and nearly all cases were again being tried in Charleston. ${ }^{3}$ It was not a great while before they dropped out of the srstem entirely. The chief difficulty seems to have been the lack of legal training among the judges.

\section{The Admiralty Court}

Previous to 1697 , there was no court of admiralty in the province, maritime cases being tried before the common law courts. ${ }^{4}$ Frequent complaints were made by the king's collectors of the customs that the common

IStatutes, II, 17S-183.

${ }^{2}$ Council Journals, 1/s., III, 167.

S Statutes, III, 287-2S8.

- Commissions, to be sure, were issued in 1685 and from time to time thereafter for the trial of pirates; but they did not constitute admiralty courts in the strictest sense of the term. Ibid., II, 7-9, 25-27. 
law judges would not give the proper assistance in enforcing the acts of trade and navigation.' Finally, in 1696, owing chiefly to the representations of Edward Randolph, the English government announced its intention of establishing admiralty courts in all of the colonies." The proprietors of the Bahamas, Carolinas, Pennsylvania, and the Jerseys, and the agent of Connecticut sent a memorial to the Board of Trade, December 16, 1696, stating that they had not yet erected admiralty courts because it would be an expensive proceeding and because breaches of the navigation acts could, by the 15th Charles II, be tried in the common law courts. However, they declared that they were willing to establish such courts and to do all in their power to enforce the navigation laws. ${ }^{3}$

The question at issue now was whether the English government or the proprietors should establish and regulate the courts. The Board of Trade settled the question, so far as South Carolina was concerned, by erecting a court of vice-admiralty in Charleston in 1697 with Joseph Morton as judge, Thomas Carey register, J. Amory advocate, and R. Pollinger marshal." These officials and their successors until the time of the Revolution were appointed by the admiralty board in England, usually, before 1719, upon the recommendation of the Lords Proprietors. ${ }^{5}$

1 Public Records, IIs., II, 223-224.

2 Randolph Papers in Prince Society Publications, Vol. XVI, Part V, 31-35, 117-124, 130-132.

${ }^{3}$ New Jersey Archives, First Series, II, 133-134.

4 S. Car. His. Soc. Col., I, 207.

${ }^{5}$ Public Records, Ms., V, 263, 266. 
In order to enforce the revenue laws more strictiy, parliament passed an act in 1764 providing for a court of vice-admiralty over all America, with headquarters at Halifax. The Earl of Northumberland was appointed vice-admiral and William Spry judge. Opened October 9,1764 , this court met with opposition throughout all the colonies and accomplished very little. ${ }^{1}$ A suggestion was made a year later that it should be removed to Boston, but this was probably not carried into effect. ${ }^{2}$

In 1768 a more elaborate scheme was proposed. On July 6 of that year, His Majesty in council ordered the erection of four vice-admiralty courts in America: one at Halifax, for Quebec, Newfoundland, and Nova Scotia; another at Boston, for New Hampshire, Massachusetts Bay, Rhode Island, and Connecticut; a third at Philadelphia, for New York, Pennsylvania, the lower counties on the Delaware, Maryland, and Virginia; and a fourth at Charleston, for North Carolina, South Carolina, Georgia, East Florida, and West Florida. The court at Charleston was to have jurisdiction over all cases arising from the capture of ships south of $36^{\circ} 45^{\prime}$ north latitude or of ships bound for some port in the district. It was given appellate jurisdiction over the courts of vice-admiralty established or to be established in any of the colonies of the district. ${ }^{3}$

Sir Augustus Johnson, who was appointed judge for

1 Charles W. Tuttle in Mass. Hist. Soc. Proceedings, First Series, XVII, 291-293.

${ }^{2}$ Washburn, Judicial Hist. of Mass., 175; New .Jersey Archives, First Series, IX, 620-621. See Whitney, Govt. of the Colony of S. Car., Johns Hopkins University Studies in Hist. and Pol. Seience, XIII, 88-89.

s Public Records, Ms., XXXVI, 219-227. 
the souther'n district, arrived in Charleston in May, $1769,{ }^{1}$ but there is no indication that any serious attempt was ever made to put the system into operation. Consequently, the only court of vice-admiralty in the province was that established in 1697 . The court records from 1716 to 1763 , with the exception of a hiatus from 1749 to 1752 , are preserved in the office of the clerk of the United States District Court at Charleston."

For the sake of convenience, the powers and jurisdiction of the court may be considered under the following topics: piracy, treason, felony, and murder; acts of trade and navigation; maritime cases in general; and prize cases.

Previous to the reign of Heury VIII, piracy was a felony only by the civil law and was not at all cognizable by the common law. The civil law, which furnished the rules of procedure in the admiralty courts, would not allow a man to be condemned to death unless he confessed the crime or was convicted on the testimony of eye witnesses. Many notorious offenders thus escaped punishment entirely. To remedy this defect, the act of 28 Henry VIII, chapter 15 (1536), took piracy cases out of the courts of admiralty and provided for jury trials before a special commission selected by the lord chancellor and not restricted by the civil law procedure. ${ }^{3} \quad$ South Carolina adopted this method of trial as early as 1685, although the English law on the sub-

${ }_{1}^{1}$ Publie Records, IIs., XXXII, 76 ; s. Car. Gazette, No. 1760, June 15,1769 .

2 These records are bound in three large folio volumes, the first designated as $\mathrm{A}$ and $\mathrm{B}$, the second as $\mathrm{C}$ and $\mathrm{D}$, and the third as $\mathrm{E}$ and $\mathrm{F}$. The pages are not numbered in the first two rolumes.

${ }^{3}$ Chalmers, Colonial opinions, 511-512. 
ject was not formally declared in force until 1712 , when it was included among the large number of statutes adopted at that time. The act of 1712 also conferred upon the governor and council all the powers of the lord chancellor of England or of the lord keeper of the seals in the execution of these statutes. Consequently, the governor and council selected the persons to serve on the various commissions from time to time, though the commissions themselves were made out in the name of the Lords Proprietors and later of the king. One commission, dated November 27,1716 , is directed to Nicholas Trott, judge of the admiralty, and ten assistants, of whom there were four ship captains, a member of the council, the speaker of the assembly, two merchants, and two other persons. Attention is called to the act of 28 Henry VIII against piracy, especially to the clause providing that all treasons, felonies, robberies, and murders committed on the high seas or in any ports should be tried the same as if committed on land. The commission then went on to confer upon Trott and any three assistants as full powers as any commissioners in England might have. ${ }^{1}$

Not only piracy, but cases of murder, robbery, and felony on the high seas were to be tried before the commission. There were several trials for piracy held between 1716 and 1719 . The procedure was about as follows: A grand jury, containing from thirteen to twenty-three members, was first sworn in; the advocate-general then presented indictments against the sus-

${ }^{1}$ Admiralty Court Records, Ms., $\mathrm{A}$ and $\mathrm{B}$. 
pected parties; in case a true bill was found and the defendants pleaded not guilty, they were brought before a petty jury for trial, and their decision was final. ${ }^{1}$

This commission did not in the proper sense constitute an admiralty court, though it was presided over by the judge of the vice-admiralty and its proceedings are given in the admiralty court records. Trial was always by jury and according to the common law, while the admiralty court proper proceeded without a jury and according to the civil law. It was sometimes designated as "the royal commission for holding admiralty sessions." Under the statute of 28 Henry VIII it possessed a wide jurisdiction over cases of treason, felony, robbery, or murder on the high seas. Later commissions, however, based upon the statute of 11 and 12 William III, chapter 7, tended to narrow its powers.

In 1769 a certain Matthew Turner was tried for the murder of Captain Harrop, convicted, and sentenced to be hanged. He was reprieved by the governor until His Majesty's pleasure could be known, and the case came before the home government for final settlement. The Earl of Hillsborough informed Lieutenant-Governor Bull that in a similar case, which had recently come up from New York, the crown lawyers gave the opinion that the commissions in the colonies had no authority, under the statute of 11 and 12 William III, to try per-

I Admiralty Court Records, $\mathbf{M s}$., A and B passim. For a complete description of some of these trials see Hughson, Carolina Pirates and Colonial Commerce, in Johns Hopkins Univ. Studies in Hist. and Pol. Science, XII, 299-301, 338-344, 356-357. 
sons charged with murder on the high seas. They were to be sent to England for trial. ${ }^{1}$

The court of vice-admiralty, as we have seen, was first erected in South Carolina in order to enforce the acts of trade and navigation. Until the passage of the statute of 7 and 8 William III, chapter 22, it was an open question whether admiralty courts in the provinces had jurisdiction over cases arising under these acts. By this law, enacted in 1696, penalties for carrying goods in ships not manned according to law could be sued for in any court of record at Westminster, or "in any court in His Majesty's plantations where such offence shall be committed." From this it would seem that the courts of vice-admiralty in the provinces were to have concurrent jurisdiction with the common law courts. All other penalties provided for by the trade and navigation laws, however, were to be sued for in any of His Majesty's courts at Westminster or in Ireland "or in the court of admiralty held in His Majesty's plantations respectively, where such offense shall be committed, at the pleasure of the officer or informer, or in any other plantation belonging to any subject of England, wherein no essoin, protection, or wager of law shall be allowed." That is to say, the provincial courts of vice-admiralty were practically given exclusive jurisdiction over all cases arising under these laws.

As if there could be any further doubt after the passage of this act, the whole question was referred to the

${ }^{1}$ Public Records, Ms. XXXII, 80, 286-287, 308-309. For an account of the New York case see Nev York Col. Doc., VII, 446, 454-455; Chalmers, Colonial Opinions, 525-527. 
law officers of the crown. Opinions were delivered by Sir John Cooke, July 23, 1702, ${ }^{1}$ and by Attorney-General Northey, August 21, 1702,2 defending the jurisdiction of the admiralty courts.

Numerous cases of the violation of the acts were tried from time to time. As early as January, 1700, a ship called the Cole and Beale galley was forfeited for illegal trading. ${ }^{3}$ A case decided in July, 1729, will serve to show the general method of procedure. Don Pedro Ramon sailed from Charleston with a cargo of goods in the coal St. Antonio, which did not comply with the provisions of the law requiring ships to be built and owned in England or the colonies, and to be manned by crews of whom three-fourths were Englishmen. Thomas Gadsden, collector of the customs, presented an information against Ramon, and the case came to trial before Judge Whitaker. Mr. Hume and Mr. James Graham represented Gadsden and Mr. Charles Pinckney looked after the interests of the defendant. After several days spent in hearing arguments, the judge decided, July 12, that the vessel and its cargo should be sold and the proceeds, after all fees were paid, divided equally between the king, President Middleton, and informer Gadsden. ${ }^{4}$

Suits of mariners against masters of vessels for wages due them were tried in the court of vice-admiralty. Such a case came up in August and September, 1729,

1 Forsyth, Cases and Opinions on Constitutional Law, 91-93.

2 Chalmers, Colonial Opinions, 499-502.

3 Public Records, Ms., IV, 148-160.

- Admiralty Court Records, Hs., A and B. Middleton received his share as acting governor of the province. 
between Nicholas Worsdale, late mate, and Thomas Barry, master of the snow William. ${ }^{1}$ Another class of cases originated as follows: When a ship came into the harbor badly damaged by storm, the master would apply to the judge of the vice-admiralty for some one to examine it to see if it could be repaired or had best be sold at auction. The judge would appoint five or six shipwrights to examine the vessel, and, on their report, would make his decision. A large number of such cases came before the court after the great storm of $1752 .{ }^{2}$

There remain now a few words to be said in regard to the jurisdiction of the court in time of war. Letters of marque and reprisal were issued by the governor and council, and prize cases were tried before the court. Many such letters were issued during the wars with Spain and France. One of November 22, 1739, was made out to George Austin, merchant, and James Whitefield, master of a vessel. They gave a bond of two thousand pounds sterling to obey all orders from the governor. They swere empowered to take and destroy the ships, vessels, and goods of the king of Spain and his subjects, and bring into any of the ports of His Majesty's dominions the prizes captured, there to be adjudicated in the court of vice-admiralty. Then followed a list of instructions. They were not, for instance, to convert captured vessels and goods to their own use until they had been adjudged lawful prizes in a court of viceadmiralty; at least one-fourth of their seamen must be natives or naturalized subjects of Great Britain; all

1 Admiralty Court Records, Ms., $\mathrm{A}$ and $\mathrm{B}$.

${ }^{2}$ Ibid., E and F. 
laws and customs relating to privateers must be obeyed. ${ }^{1}$ Numerous prize cases were tried during the war with France in 1758-1759. One of the most important was that of Pilkington et al. vs. Snow Vrow Aletta and Cargo. The privateer Nassau captured a Dutch vessel, or snow, laden with a cargo of sugar, coffee, etc., worth about $£ 30,000$ currency, which it was said had come from the French islands. The case was long and hotly contested, but the decision was finally given in favor of the defendant, and Pilkington had to pay the costs of the suit. ${ }^{2}$ Other cases were decided in favor of the captors, as for example, those of The Officers and Men of the Penguin vs. the Pearl and Original and John Vesey et al. vs. the Sloop Hazard. ${ }^{3}$

Attempt to Establish a Court of Exchequer

In 1732, while the contest was raging between the land speculators and their opponents, the Duke of Newcastle suggested that a court of exchequer should be established to put an end to the frauds. Accordingly, on the 21st of November, 1732, the governor in council issued commissions to Chief Justice Wright as chief baron, and to Eleazar Allen, Tweedie Somerville, Thomas Cooper, and Daniel Green as puisne barons for holding courts of exchequer in the province as often as occasion should require. ${ }^{4}$ There seems to have been some doubt in regard to the validity of the order establishing the court, and the question was referred to the

1 Admiralty Court Records, $\mathbf{M}$ s., $\mathrm{C}$ and D.

${ }^{2}$ Ibid., F, 64-127.

3 Ibid., 128-172, 229-245.

${ }^{4}$ Council Journals, Mfs., V., 218, 223-224. 
home goverument. On June 12, 1738, the crown lawyers expressed the opinion that His Majesty had the undoubted right to erect a court of exchequer in South Carolina with all the powers of the English court of exchequer. They suggested, however, that it might be advisable to send out a special commission authorizing the governor to establish it. ${ }^{1}$ The court was never of any consequence and soon became entirely obsolete. Lieutenant-Governor Bull, in a letter of 1770 , states that the people destroyed it by refusing to appear when summoned as jurors. They were able to do this because the jury act of 1731 did not require attendance on the court of exchequer and the assembly would not pass a new law on the subject. ${ }^{2}$

1 Chalmers, Colonial Opinions, 481-485.

2 Public Records, Ms., XXXII, 379-380. 


\section{CHAPTER IV}

\section{Colonial Agents}

There is, perhaps, no topic connected with colonial history more interesting or more instructive than a study of the English administrative system of the seventeenth and eighteenth centuries. Although we cannot take up the subject here, a word or two should be said, by way of recapitulation, in regard to the intimate relations existing between the royal province and the home government. The governor, council, and various other officials were appointed and their powers and duties regulated by commissions and instructions from abroad; all laws were sent to England immediately after passage, and if disapproved, became null and void. As a consequence, the people soon began to see the absolute necessity of having a regular agent in London to explain colonial laws, to protest against obnoxious instructions, to lay petitions before the king and parliament, and, in short, to act as a general lobbyist. These agents were of various kinds: there were the regular colony agents, elected for a definite term by act of the general assembly; special agents, elected also by an act of the general assembly, but only to advocate some particular measure or to protest against some particular grievance; agents of the lower house alone, whose principal duty was to advocate the cause of the assembly in their 
continual struggle with the governor and council; agents of the council alone; and finally, extra-legal agents sent by political factions within the colony. ${ }^{1}$

The earliest instance of an agent in South Carolina is of the latter description. John Ash and, later, Joseph Boone were sent over by the Dissenters in 1704 1705 to protest against the religious disqualification act. The success of their mission has already been noticed in the chapter on the proprietary period.

On December 12, 1712, the first "Act for appointing an Agent to solicit the affairs of this Province in the Kingdom of Great Britain" was passed. Landgrave Abel Kettleby was appointed to represent the interests of the province before parliament and the proprietors. He was authorized to use his best efforts to procure a continuation of the bounty on naval stores exported from South Carolina to Great Britain, and to secure permission to export naval stores and rice to Spain, Portugal, and all places in Africa and America, or to as many of the said places as possible. A committee of five was appointed to correspond with him and send over instructions. He was to receive one hundred and fifty pounds currency as an inducement to undertake the agency, as much more in case the bounty act was renewed, and five hundred pounds whenever parliament passed an act allowing the shipment of rice to the places mentioned above, or a proportional amount for as many of those places as could be procured. As no particular term of service was mentioned and no annual

1 For a very thorough general discussion of this subject see the article on Colonial Agencies in England during the Eighteenth Century by E. P. Tanner in Pol. Seience Quarterly, March, 1901, Vol. XVI, 24-49. 
salary provided, Kettleby may be classed as a special agent. ${ }^{1}$

Two years later, another act was passed fixing his salary at two hundred pounds per annum and providing for his continuance as agent "until removed by a vote of the House of Commons, who shall from time to time have power to appoint and depose the aforesaid Agent and his successors according to their discretion forever."' Thus the colony agent became the agent of the lower house.

Kettleby's special mission was to represent the interests of the province before parliament. The assembly were evidently afraid to trust him in their contest with the proprietors, for they passed an order, February 24, 1715, constituting Joseph Boone and Richard Beresford agents to transact the affairs of the province with the Lords Proprietors. ${ }^{3}$ They were instructed to apply for a redress of grievances, to desire a final settlement of the price of lands, to ask for county courts, and to complain of Chief Justice Trott's monopoly of judicial offices. In case the proprietors would afford no relief, they were to appeal to a higher power. It was resolved that they should be paid two thousand pounds for their services by ordinance of the general assembly. ${ }^{5}$ The other branches of the legislature failed

istatutes, II, 600-602. Rice was at this time one of the enumerated articles which could be exported only to Lngland. 3 and 4 Anne, chapter 5 , section 12 .

2 Statutes, II, 621-622.

${ }^{3}$ Com. House Journals, $\mathrm{Ms}$., IV, 372.

4 Ibid., 378-380.

5 Ibid., 383. Kettleby resided in England, Boone and Beresford in the province; hence their expenses were heavier and they had to be paid higher salaries. 
to observe this resolution; Deputy Governor Daniel held up the tax bill in June, 1716, until the clause providing for them was struck out.' As we shall see in another connection, the dispute over this matter dragged on for several years after the province came under the crown. ${ }^{2} \quad$ Kettleby continued to act as agent until December 10, 1716, when he was dismissed by the order of the lower house. ${ }^{3}$ Beresford returned to South Carolina soon afterwards and Boone remained the sole agent. It was largely through his representations that the English government was induced to take charge of the province after the overthrow of proprietary rule.

A regular colonial agency, created by act of the general assembly for a definite time, with a definite salary, and equally under the control of council and assembly, did not come into existence until after the establishment of the royal government. By an act of September 19, 1721, provision was made for such an agency. The preamble stated the necessity of having some one in England to look after the interests of the province and declared that this could best be done by sending a member of the council and a member of the commons house who were well versed in provincial affairs. Accordingly, Francis Yonge of the council and John Lloyd of the assembly were selected. ${ }^{*}$ They were instructed to

${ }^{1}$ Com. Mouse Joumals, Ms., V, 130-132.

2 See Chapter VI, Finaneial History.

3 Com. House Journals, IIs., V, 18 .

4 Yonge, it will be remembered, had been sent to England by Governor Johnson in 1719 to try to induce the proprietors to make some concessions to the people. See the introductory chapter on the Proprietary Period. 
obey such order's as they might receive from the governor, council, and assembly before embarkation, and from the committee of correspondence afterwards. This committee consisted of Honorable Arthur Middleton and Mr. Ralph Izard from the council, and Messrs. Richard Allein, William Blakeway, Thomas Hepworth, Charles Hill, and Andrew Allen from the commons house, any three of whom were to constitute a quorum. ${ }^{1}$ An additional ordinance, ratified two days later, added Richard Beresford and John Barnwell, members of the commons house, and increased the quorum to four, of whom one at least should be a councilor. ${ }^{2}$ They were to carry on a regular correspondence with the agents, send over the orders of the general assembly, and give such instructions as they thought proper, when the general assembly was not in session. ${ }^{3}$ The agents were paid three thousand one hundred pounds currency in advance. The act was to continue in force one year from the date of ratification. ${ }^{4}$

A glance at the instructions to Yonge and Lloyd will convey some idea of what an agent was expected to do. They were to make an effort to induce the crown to pur-

${ }^{1}$ Statutes, III, 146-14i.

2 Ibid., 15i. Both of these men were well qualified. Beresford was the same who had been agent with Boone, while Barnwell had just returned from a special mission to England.

${ }^{3}$ This committee, revived from time to time, was continued in existence until the Revolution. During the last few years of the colonial period, however, its member's were nearly all drawn from the lower house and it was entirely under their control. When the colonies began to appoint committees to correspond with one another in 1773, the South Carolina assembly found it unnecessary to appoint a new committee and simply utilized this.

Ibid., 146-147. 
chase the territorial rights of the proprietors and make North Carolina a dependency of South Carolina; to ask His Majesty to supply the province with arms and ammunition and to send over three or four regiments to protect the frontiers; to represent the dangerous consequence of the encroachments of the Spanish and French and especially of their intrigues among the Indians; to complain to the commissioners of the customs about the conduct of Colonel William Rhett, surveyor and comptroller of the customs; to solicit leave to make Port Royal a port of entry; to ask that Charleston might be incorporated with a charter similar to that of the city of New York; to endeavor to secure a bounty on naval stores and to have rice taken off the enumerated list; to answer questions relative to the state of the province; and, finally, to solicit the royal assent to all acts and ordinances sent over by the provincial assembly. ${ }^{1}$

Lloyd returned to South Carolina in the sinter of 1722-23. With one or two short intermissions, during which the province had no agent, Yonge was regularly re-elected until 1727. His salary soon became definitely fixed at two hundred pounds sterling per annum. ${ }^{2}$

Yonge was succeeded in April, 1727, by Mr. Samuel Wragg, a London merchant who carried on trade with the province. ${ }^{3}$ Owing to the long deadlock between the council and assembly over the currency bills, Wragg's term was allowed to expire and the regular agency was

1 Public Records, IIs., IX, 121-131.

2 Statutes, III, 183, 251-252, 267-268.

s Ibid., 266-267. 
vacant until the re-establishment of order after Governor Johnson's arrival. In 1729 the council appointed Stephen Godin, another London merchant, agent to represent their views in England and to try to obtain proper instructions from the king to the governor who was about to be sent ont. ${ }^{1}$

On August 20, 1731, Peregrine Fury was elected agent for one year at a salary of one hundred pounds sterling. ${ }^{2}$ The salary was soon increased to two hundred pounds sterling, equal to fourteen hundred pounds currency, and this continued to be the regular allowance during the remainder of the colonial period. Fury also resided in London and was highly recommended by His Grace the Duke of Newcastle. ${ }^{3}$ He filled the position of agent continuously for eighteen years and always proved himself to be a capable, honest, and efficient servant. During this period there originated a custom, adopted merely for convenience, which later gave rise to considerable controversy. This consisted in allowing the agent to continue in service after the act of appointment had expired. Appointed for one year by the act of March 17, 1733, Fury served for five years, and was regularly provided for in the tax estimate, before another act on the subject was passed. Subsequently, he was appointed for two years, and served three.

For some reason, probably because of his failure to induce the British government to approve the paper

I Public Records, Ms., XIII, 238, 350-372.

2 Statutes, III, 307-308. The name is sometimes spelled Furye.

${ }^{3}$ Council Journals, Ms., V, 112.

¿Ibid., 405; Grimké, Public Laws of S. Car., p. xxi; Com. House Journals, Ms., X, 21-22, XXX, 585-586; Statutes, VI, 616-617. 
money act of June 17,1746 , the assembly began to tire of Fury. In June, 1747, they passed an act appointing Mr. John Sharpe agent, which the council amended by substituting Fury's name. By a vote of ten to nine the amendment was accepted, and Fury was retained for two years longer.' Finally, in May, 1749, a proposition to continue him in service was voted down, and $\mathrm{Mr}$. James Crokatt was elected in his place. ${ }^{2}$ Crokatt had for many years been one of the leading merchants of Charleston. In June, 1739, however, he closed up his affairs in the province and went to London, where he had since been in business. ${ }^{3}$ Governor Glen's speech on ratifying the ordinance of appointment suggests that Crokatt was personally obnoxious to him. Thus, after complaining of the dismissal from service of an old and faithful servant whose conduct had been approved for many years, he assured the assembly that they could not have chosen a more suitable person than Mr. Crokatt, if they had any complaints to make against their governor. ${ }^{4}$

On July 6, 1753, Crokatt wrote to the committee of correspondence of the general assembly asking leave to resign. He stated that he was sorry that he had ever accepted the post, since it conflicted with his private business, and that he would have resigned long before had he known of any good person to succeed himself.

${ }^{1}$ Com. House Journals, Ms., XXII, 722, 749; Grimké, Public Lau's of S. Car., p. xxxvii.

${ }^{2}$ Com. Housc Journals, Hs., XXIV, 337-338; Statutes, III, 723.

${ }^{3}$ S. Car. Gazette, No. 279, June 9, 1739; Public Records, Ms., XX, 363.

'Com. House Journals, Ms., XXIV, 619-620. 
Mr. Charles Pinckney had recently arrived in London with the intention of living there, and he suggested that the general assembly would do well to appoint him. ${ }^{1}$

The council accepted the resignation and requested the lower house to appoint a committee to confer in regard to the choice of his successor. Governor Glen urged that Fury should again be appointed. The assembly declared that they hoped to retain Crokatt as agent and had written urging him to reconsider his resolution to resign. This reply aroused the anger of the council and they hastened to call attention to the fact that the ordinance appointing Crokatt had long since expired and that there could be no legally constituted agent without a new ordinance. The answer to this was that both Fury and Crokatt had acted as agents for many years after the expiration of the ordinances appointing them. If they did, said the council, it was only by the joint consent of all three branches of the legislature. They could see no reason for withdrawing from their resolution to accept the resignation. ${ }^{2}$

A recess of the assembly put an end to the conflict for a time, but it was renewed when the houses met again in January, 1754. A letter had, in the meantime, been received from Crokatt agreeing to continue as agent. ${ }^{3}$ The question now was in regard to the payment of his salary. If that could be secured, he might still serve the province without any formal ordinance of re-election. Practically, it meant, could the assem-

${ }^{1}$ Council Journals, Ms., XXII, 90-92.

${ }^{2}$ Com. Honse Journals, Ms., XXIX, 60-61, 62, 7i-78, 122-123, 124$125,128-129$.

3 llid., XXIX, 458. 
bly through its assumed control over money bills keep an agent in office against the will of both governor and council? In the yearly estimate, as first drawn up on March 12, Crokatt's salary of fourteen hundred pounds currency was placed under the head of allowances to public officers, while his account of disbursements, amounting to one hundred and fifty-nine pounds, fifteen shillings, six pence, came under the head of writing and printing for the public service. ${ }^{1}$ A revision was made a few days later, in which his name was omitted under the head of public officers and the entire sum for services and disbursements placed under the head of writing, printing, and other services for the public. ${ }^{2}$ The council expressed surprise at this transfer and asked to have the particulars of Mr. Crokatt's services sent them so that they could form some judgment of the reward to which he was entitled. ${ }^{3}$ The assembly now became indignant and informed them that the agent of the province was paid by the people and that he should be selected by the representatives of the people, notwithstanding his appointment could be made legally only with the consent of governor and council. They, the representatives of the people, were voting the people's money and were accountable to none but their constituents. Then followed the most important part of the message, a copy of a resolution of the assembly, "That no Account, Petition, or other Paper that shall be laid before this House for the future of, for, or concerning any claim or demand whatever for any

${ }^{1}$ Com. House Journals, Ms., XXX, 346-347.

2 Ibid., 389.

3 Ibid., 404. 
matter or thing done or to be done for the service of the Public shall be sent to the council for their Inspection.", The reply of the comncil, made April 9, was in an angry, defiant tone. There was no essential difference, they declared, between giving Mr. Crokatt fourteen hundred pounds as a public officer, which he was not, and roting him the same amount for services which he had not performed. He had no legal standing whaterer. He was empowered by law to correspond with a committee of both houses; but none such existed, for the council had accepted his resignation and refused to appoint their part of the committee. He certainly had no right to correspond with either house separately.'

The lower house still refused to amend the estimate, and the tax bill was rejected by the council, April 12, because of the obnoxions item..$^{3}$ A second bill, passed a few days later, met the same fate. ${ }^{4}$ The clamor of public creditors, together with the need of money to aid the northern provinces in the French and Indian War, rendered an early settlement of the dispute an imperative necessity. Governor Glen remonstrated with the comncil and they agreed to pass a tax bill without change. Accordingly, a third bill was introduced and enacted into a law, May 20, 1755.5 This was a double victory. It meant not only that the agent was to be merely the servant of the lower house, but it was another step in asserting absolute control over money bills.

1 Com. House Journals, IIs., 40s-111.

2 Ibid., $425-429$.

3ltid., 438. 441-4+2; Council Journals, IIs., XXIV, 60.

+ Council .lournals, .1/s., XX1T, 84.

5Ibid., 92-93; Public Records. JIs., XXVI, 190-192; Statutes, IV, $18-19$. 
Having carried their point, the house magnanimously agreed to substitute another agent for Crokatt. Mr. William Middleton was elected Narch 19, 1756, but he refused to serve, and Mr. James Wright was chosen for a two years' term, November 19, 1756 . Wright was the son of Chief Justice Robert Wright, who incurred the anger of the commons on account of his defence of the habeas corpus act during Governor Johnson's administration. He was a native of the province and had just served it for fifteen years as attorney-general. Reaching England in October, 1757, he continued as agent until July, 1760, when he resigned to accept a commission as lieutenant-governor of Georgia."

The province was without an agent until May 19, 1762, when Charles Garth, son of John Garth, member of parliament for Devizes, was appointed. ${ }^{3}$ He served as agent from 1762 until relations with England were broken off in 1775 . During part of this time he also represented the interests of the lower house of the Maryland legislature. In 1765 he succeeded his father in parliament and was thus placed in a position to render his clients more effectual aid. ${ }^{5}$

${ }_{1}$ Statutes, IV, 26-27, 34-35; Com. House Journals, Ms., XXXI, Part II, 7 .

${ }^{2}$ Com. House Journals, Hs., XXXII, Part II, 51. Wright arrived in Georgia in October, 1760, was appointed governor in March, 1761, and created a baronet in December, 1772. He was the last royal governor of Georgia. Jones, History of Gcorgia, I, 541, II, 26, 126.

${ }^{3}$ Statutes, IV, 164-165; S. Car. Gazette, April 3, I762.

4 Maryland Archives, Correspondence of Governor Sharpe, III, 3506, 385, 431; Mereness, Maryland as a Proprietary Province, 372-373, 474, 481 .

${ }^{5}$ S. Car. Gazette, April 20, 1765. 
The ordinance, under which Garth was appointed, provided for a committee of correspondence consisting of any four members of the council, chosen by themselves, and the speaker and such of their members as the lower house should choose. Nine were made a quorum and there was no provision that any of them should come from the council. The assembly appointed seventeen members on the committee. ${ }^{1} \quad$ The result was that all the council members could not form a quorum or even a majority of a quorum, whereas the assembly member's could meet and do business without a single councilor being present. This was exactly what they did, and many were the reports and letters which they sent to and received from the agent of which the governor and council were entirely ignorant. Through him the assembly made complaint to the king of Governor Boone's conduct in the Gadsden case, ${ }^{2}$ and through him a memorial was presented to the Earl of Shelburne complaining of Chief Justice Skimner. ${ }^{3}$ He defended the lower house in the Wilkes fund controversy and labored to secure the recall of the additional instruction of April 14,$1770 ;{ }^{4}$ he joined with the agents of the other colonies in urging parliament to repeal the revenue acts. ${ }^{5}$ These and many similar services indicate how completely the province agent had become the servant of the assembly. The advantage of such an ally cannot be orerestimated.

I Statutes, IV, 164; Com. House Joumals, Is., XXXV, 121.

2 Public Records, Is., XXX, 149-15?.

3 Ibid., XXXI, 274-273.

4 Ibid., XXXII, 422-425.

s Com. House Jounals, Ms., XXXVII, 691-692. 


\section{CHAPTER V \\ Militia and Defense}

\section{Militia}

Occupying for many year's the position of an extreme outpost of the English colonies, South Carolina was exposed to many dangers. There were the Indians almost surrounding it, the Spaniards at St. Augustine, and the negroes at home. The province was weak at its establishment and was doomed to remain so. The tendency of the Fundamental Constitutions and of the Barbadian immigration was to build up an aristocratic settlement - an aristocracy based on slavery. It has become an axiom of political economy that free labor and slavery can never flourish side by side. So in South Carolina, until the Scotch-Irish migration toward the close of the colonial period, we find very few white laborers, only a sprinkling of indented servants and transported convicts, the progenitors of the "poor" white trash" of a later day. The whites were soon vastly outnumbered by the blacks, and to their other misfortunes was thus added the continual fear of a slave insurrection, especially as the Spaniards encouraged the negroes to revolt and offered freedom to all who could escape to St. Augustine.

The war's with the Spanish in 1686 and 1702-1704, the combined attack of the Spanish and French on 
Charleston in 1706, the Yemassee war in 1715, the contest with the pirates in 1718 , the slave uprising of 1739 , the struggle with the Spanish in 1740, the war with the Cherokees in 1760-1761, and, finally, the contest with the mother country itself, all taught the Carolinian the necessity of being well trained in the use of arms and ready to go to the front on a moment's notice.

Under the proprietary rule they were compelled to rely on their own resources exclusively, and, during the royal period, very little help was ever received from England. Accordingly, we find the colony on Ashley river, shortly after its settlement there, making provision for a militia organization. On October 26, 1671, the grand council passed an ordinance which required all of the men in the settlement, except members of the council and their attendants, to meet at the times and places appointed by the company commanders to exercise in the use of arms and accustom themselves to military discipline. Penalties vere provided for those who refused to appear at the stated times. Provision was also made for volunteer watches in the city, a duty likewise enforced by penalties. ${ }^{1}$ We are informed by a letter from Governor West to Lord Ashley that in March, 1671, there were less than one hundred and fifty men in the colony and they were divided into two companies. ${ }^{2}$ A few colonists arrived from Barbadoes and England during the latter part of the year, and by January, 1672, the number able to bear arms had increased to two hundred and sixty-eight. ${ }^{3}$

I Council Journals, Hs., I, 11-12.

2 Shaftesbury Papers, S. Car. His. Soc. Col., V, 296.

${ }^{3}$ Ibid., 382. 
The colony now continued to grow, and the militia no doubt drilled regularly. The earliest statutes have not been preserved; not even a title is found before 1682 . Among the five laws enacted that year is one entitled, "An Act for settling the militia." Similar acts were passed in 1685, 1687, 1690, 1693, 1696, 1697, and 1701, none of which is extant. ${ }^{1}$ Each of them probably expired in two or three years and the following act embodied some new features, so that by the end of the century the form had become fixed. At any rate, the act of 1703 , which is the earliest that has been preserved, differs little from those of Revolutionary times. During the eighteenth century militia laws were passed in $1701,1703,1707,1721,1734,1739,{ }^{2} 1747,1760,1778$, 1782,1784 , and 1794 , the last being supplemented by acts of $1795,1796,1797$, and $1800 .^{3}$ These laws were usually enacted for definite periods, ranging from one to seven years, and reviving acts were passed from time to time.

At first the militia consisted entirely of infantry, but as early as 1721 there was a troop of cavalry under the command of Colonel Joseph Blake, ${ }^{4}$ and in 1757 an artillery company was established in Charleston. ${ }^{5}$

Taking up the system in detail, we come first to the officers. ${ }^{6}$ The governor of the province was commander

I Statutes, II, v, 3S, 40, 7テ, 124, 135, 182; Grimké, Public Laus of S. Car., pp. vi, ix.

${ }^{2}$ An additional and explanatory act.

3 Statutes, II, 182, VIII, 485-508, IX, 617-691.

- Public Records, Extra, Us., I, Part I, 24.

5 S. Car. Gazette, No. 1179, January 20, 1757.

${ }^{6}$ The account given here is based upon the law of 1747 . Statutes, IX, $645-663$. 
in chief of all the forces. He could, in time of war, either lead them in person, as for instance Governor Moore in the St. Augustine expedition (1702) and Governor Johnson in the attack on the pirates (1718), or appoint some one else to do it. His duties were to issue commissions to officers, sign warrants for the collection of fines and for the impressment of food and provisions in time of danger, employ watches for the frontier, declare martial law with the consent of his council, and sit with the council as a court for the trial of field officers. In 1721 there were two lieutenant-generals, Robert Johnson in command of the forces in Berkeley and Colleton counties, and James Moore of those in Craven and Granville counties. ${ }^{1}$

Regimental officers were the colonel, lieutenantcolonel, major, and adjutant, with the customary duties of such officers. The young planters usually held these positions by turns, one set serving for a year or so and then giving way to another. The titles, however, remained with them, a fact which will account for the large number of colonels and majors in South Carolina before the Civil War.

The principal officer of the company was of course the captain. He was required to enroll the names of all men of military age in his parish or division, and to train, exercise, and muster them. He appointed two sergeants in his company, who were compelled to serve for one year. Their duties were to execute warrants for fines on those who failed in their obligations, to arrest and confine them in the common gaol at Charles-

1 Public Records, Extra, Ms., I, Part I, 11. 
ton until such fines were paid, and to go with the captain on his bi-monthly trip to see that all his men were properly armed. The marshal occupied the corresponding position in the cavalry.

In every county there were one or more regiments and in every parish one or more companies. The larger' parishes were divided by the field officers into divisions, each of which furnished one company. Each company was mustered six times a year within the parish. When three companies were mustering at the same time within six miles of one another, they joined together in battalion muster, provided that no company was to be compelled to go out of its own county.

The militia included all white males between the ages of sixteen and sixty with certain exceptions, among them being members of the council and assembly and their officials, crown and provincial officers, ministers of the gospel, pilots, ferrymen, and white servants employed outside of Charleston. In time of actual invasion, rebellion, or insurrection, all of these men were required to serve except members of the council and assembly, pilots, and ferrymen. White servants and apprentices serving within the limits of St. Philip's, Charleston, were armed by their masters and compelled to attend all musters. Masters were further required to make out lists of their male slaves between the ages of sixteen and sixty and to return them to the captains of their respective companies, making special note of such as were faithful. These were armed and pressed into service in time of alarm and actual invasion. In order that the man who had the largest number of faithful 
slaves might not be required to bear more than his share of the public burdens, it was provided that the owners should be paid seven shillings six pence per day for each slave, and in case the slave was killed, receive pay for him in full. The proportion of slaves in companies outside of Charleston was never to exceed one-third, nor, in Charleston, one-half of the whole number.

As an incentive to valor, a system of pensions was provided for such poor free whites as might be wounded or killed in service. Slaves and white servants, for taking prisoner one of the enemy or capturing his colors, gained their freedom, the masters to be reimbursed out of the public treasury. Slaves who were especially brave in time of action, but who performed neither of the deeds mentioned above, received "from the public treasurer, yearly, and every year, a livery coat and a pair of breeches made of good red negro cloth, turned up with blue, and a black hat and a pair of black shoes, and shall that day in every year during their lives on which such action shall be performed, be freed and exempted from all personal labor and service to their owner or manager."

Every person who was liable to service was required to keep in his house and bring with him to muster a gun or musket, powder-horn and shot-ponch filled with ammunition, four spare flints, a bayonet, and a sword or hatchet. The commissioned officers in each company made occasional trips from house to house to enforce this provision.

An elaborate system of fines and penalties was devised for the enforcement of the law. A fine of three pounds 
currency was the penalty for failure to appear at ordinary muster and five pounds for the general muster. These fines were collected by the company sergeants under warrant from the governor, and the money was kept by them. All other fines exceeding three pounds were turned over by the sergeants to the public treasurer, and all under that amount were kept for their own use.

There were a number of miscellaneous provisions in the law which should be noted. No civil process except for treason, felony, or breach of the peace could be served on persons going to or returning from muster. In removing from one district to another, a man was held responsible for service in the old district until he presented proper certificates to show that he had enrolled in the new one. In case of prospective invasion the governor gave the signal by firing six large guns at Charleston, two at a time, three minutes apart, and the alarm was passed from company to company throughout the province, either by couriers or by the firing of small arms.

A few words should be said in regard to the artillery, the watch, and the patrol system. The Charleston settlers were very early trained in the use of cannon, but no regular artillery company seems to have been formed until 1757. The Gazette of January 20,1757 , states that several gentlemen had entered into an association to form an artillery company, and had already presented a petition to the governor praying that it should be regulated by act of the legislature, 
so as to be of real utility and not for mere parade. ${ }^{1}$ The company was at once organized and went into training. The Gazette of November 17, 1758, stated that the 10th, being the ling's birthday, was fittingly celebrated. His Majesty's independent companies, the provincial regiment, Colonel Beale's regiment of militia, the artillery company, and the free school boys all took part in the parade. The item went on to say that the adrantage of frequent exercise was shown by the fact that the artillery company far surpassed the militia. ${ }^{2}$ A statute of Juls 31, 1760, placed the organization on a legal basis. The company consisted of a captain, a captain lieutenant, a first and second lieutenant, three lieutenant fireworkers, four sergeants, and not exceeding one hundred privates, divided into the three classes of bombardiers, gunners, and matrosses. Each man provided himself with clothing, arms, and ammunition, while the government furnished the artillerr chest, gun carriages, powder carts, and ammunition wagons. Musters were held not less than eight nor more than twelve times a rear, and the members were excused from all further militia duty. ${ }^{3}$ An officer and a party from His Majesty's royal artillery were detailed by General Amherst in 1760 to put the new company through a course of instruction. ${ }^{4}$

Watch, as a military term, was applied in South Carolina both to the scouts stationed on the frontier in times of danger and to the night police force of Charleston.

1 S. Car. Gazette, No. 1179, January 20, 1757.

2 Ilid., No. 1257, November 17, $175 \mathrm{~s}$.

3 S'tatutes, IX, 664-666.

${ }^{4}$ Public Records, Hs., XXXis, 191. 
Examples of the former were the watches established on Watch, Otter, Edisto, Bull's and Sullivan's islands after the invasion of the French and Spanish in $1706 .^{1}$ The night watch at Charleston dates back to the very beginning of the settlement." Numerous statutes bearing on the subject were passed during the closing years of the seventeenth and the early year's of the eighteenth century. Service was compulsory and without compensation, although substitutes might be employed. The town constables were required to prepare a list of all male whites between the ages of sixteen and sixty and of female heads of families residing in Charleston. The first six named on the list stood guard under the constables, then the next six, and so on by turns. The number was increased to ten in 1709. Their principal duties were to patrol the streets, arrest suspicious characters out late at night, especially negroes, and to keep a lookout for burglars. In periods of public danger the number of watchmen was increased. ${ }^{3}$

Perhaps the most interesting feature connected with the militia organization was the patrol system. Early in the eighteenth century the blacks began to outnumber the whites about three or four to one. In time of invasion, when it became necessary to utilize as large a force as possible, we have already seen that practically all the whites as well as the better class of negroes might be called into service. The result would be to leave at home the worst class of negroes, who would be liable

1 Statutes, II, 300-302.

2 Shaftesbury Papers, S. Car. His. Soc. Col., V, 180, 288, 406-407.

${ }^{3}$ Statutes, VII, 7-8, 34-35, 54-0̃6. 
at any moment to rise in rebellion. To meet this danger the first patrol act was passed November 4, 1704. From every militia company a captain and ten men were selected and formed into a mounted patrol, whose duty it was to ride from one plantation to another, station sentries and guards, and use every precaution to prevent an uprising. They were to do this on occasions of general alarm and as often as the governor or captain of the patrol thought it necessary. They were exempted from the regular militia duty. ${ }^{1}$

Evidently the patrolmen were not compelled to go the rounds very often, for complaints began to be made that they were exempt from the ordinary militia obligations and had an easy time generally. So an act of 1721 repealed the law of 1704 , and required all patrolmen to enlist in their respective militia companies. The captain of each company was then authorized to appoint as many of liis men to ride patrol as he saw fit and to relieve them from time to time by appointing others in their places. ${ }^{2}$

The time of riding was still left to the discretion of the governor and patrol captains until 1734, when it was found necessary to maintain a more regular system. A patrol captain was commissioned by the governor in each militia district with instructions to select four men to ride with him. They were empowered to examine every plantation in the district at least once a month, to whip slaves who were caught away from home without passes, to break into negro houses and search for

1 Statutcs, II, 254-255.

${ }^{2}$ Ibid., IX, 639-640. 
concealed weapons, and to beat or even kill slaves who made resistance. The members served for one year without compensation and were exempted from militia duty. ${ }^{1}$ After the Stono insurrection (1739), an act was passed providing for the division of the province into regular patrol districts and increasing the powers of patrol riders. The militia officer's made out patrol lists for each district including the names of all owners of settled plantations, whether residents or non-residents, of all white male inhabitants possessing at least one slave, of the adult sons of men possessing two slaves, and of overseers. On each muster day, the captain of militia checked off not more than seven names on each list, of persons who were required to serve until the next muster day, a period of about two months. Women owning less than ten slaves were exempted. The various crown and provincial officers were not liable to service in person, though presumably they had to employ substitutes. $^{2}$ The patrol law of 1746 , practically the same as this act of 1740 , was renewed from time to time, was made perpetual in 1783 , and, with some slight changes, remained in force until the downfall of the slavery system. ${ }^{3}$

The militia as a whole was a fairly effective body. Company musters were held with a considerable degree of regularity and there was usually a grand general muster on His Majesty's birthday. At times, after several years of peace, the inhabitants would be lulled

1 Statutes, III, 395-399.

2 Ibid., 568-573.

s Ibid., 681-685, IV, 541. 
into a sense of security and the law would not be strictly enforced. Thus, in 1756, Governor Lyttleton wrote the Board of Trade that the militia had formerly been reckoned good, but had lately fallen into a very bad condition. ${ }^{1}$ Then, in 1771 , the Charleston grand jury presented it as a grievance that the militia officers in the province did not muster and train their companies as often as the law required. ${ }^{2}$ As the controversy with the mother country grew more bitter, the militia became active. Writing to the Earl of Dartmouth, under date of May 1, 1775, Lieutenant-Governor Bull stated that the Charleston companies were mustering very frequently in order to accustom themselves to military discipline and to be ready for service when necessary. ${ }^{3}$

The number of whites of military age at different periods was approximately as follows: 1671 , one hundred and fifty ${ }^{4}$ 1672, two hundred and sixty-eight: ${ }^{5}$ 1708 , nine hundred and fifty $;^{6} 1721$, two thousand $;^{7}$ 1749 , five thousand $;^{\circ}$ and 1774 , twelve thousand. ${ }^{9}$

\section{RANGERS}

In addition to the militia, a small force was employed in time of danger to range the frontiers. On November 14, 1716, shortly after the close of the war with the

1 Public Records, Ms., XXVII, 201.

${ }_{2}^{2}$ S. Car. Gavette, No. 1851, April 18, 1771.

${ }^{3}$ Public Records, Ms., XXXV, 88-89.

- Shaftesbury Papers, S. Car. His. Soc. Col., V, 296.

5 Ibid., 382.

6 Public Records, Hs., V, 204.

' New York Col. Doc., V, 610.

s Carroll, His. Col. of S. Car., II, 218.

${ }^{9}$ Public Records, Ms., XXXIV, 190. 
Yemassees, Deputy Governor Daniel urged the assembly to do something toward checking the inroads of the Indians and suggested that a body of men be employed to range continually. ${ }^{1}$ The house took the speech under consideration and resolved to provide for one hundred men for six months at £5 per month, two captains at $£ 15$, and two lieutenants at $£ 10 .^{2}$ A statute embodying these resolntions was ratified, December 15 , $1716 .^{3} \quad$ Men were drafted from different parts of the province and compelled to serve. ${ }^{4}$ Before the six months expired an act was passed to continue the men in service until November $1,1717.5$

They were promptly discharged on November 1, and there is no further reference to rangers in the records until December 19, 1722, when the assembly resolved that some should be stationed on the southern frontiers. ${ }^{6}$ Nothing seems to have come of this, however, as no provision for the men was made in the next supply bill. A small force, consisting of a captain, sergeant, and twenty men, was employed in 1727 and kept in service until September 29, $1736 .^{7}$

No rangers were employed from 1736 to 1744 . Then, as the result of a petition from Granville county setting forth the danger from Indians, a troop of twenty men was raised to scout between the Savannah and the Sal-

${ }_{1}$ Com. House Journals, Ms., V, 165-166.

2 Itid., 166.

${ }^{3}$ Statutes, II, 691. Title only.

4 Com. House Journals, Ms., V, 347-348.

${ }^{5}$ Statutes, III, 9.

${ }^{6}$ Com. House Journals, Ms., VI, 136-137.

'Ibid., VII, 623, 628; Statutes, III, 316, 335, 359, 391, 446, 481. 
Kehatchie rivers, that is in the present counties of Barnwell, Hampton, and Beaufort. They were disbanded after six months' service. ${ }^{1}$ On April 16, 1746, the assembly resolved to provide for two troops of twenty men each, one to range on the northern and the other on the southern frontier. Before the recruiting was completed the necessity had passed away, and those who had already enlisted were dismissed. ${ }^{2}$

In the spring of 1748 , two troops of fourteen men each were enlisted under Captains John Fairchild and James Francis, to range the country "from the Congarees to Ninety-six and from thence to the Catawba Nation.', This range included the present counties of Fairfield, Newberry, Union, and Chester and parts of the adjoining counties. Ther had orders to make prisoners of war or put to death all French and French Indians captured while going to or from the Catawba lands or found anywhere near the new townships. ${ }^{3} \quad A$ few months later they were discharged and detachments from His Majestr's independent companies were depended upon to protect the frontiers. ${ }^{4}$

These men were of little service, since they were under English officers, were inexperienced in border warfare, and were averse to being broken up into small detachments. The French continued to poison the minds of the Indians, and incursions into the frontier settlements became alarmingly frequent. Finally, in April and May of 1751, the assembly resolved to

${ }^{1}$ Com. House Journals, $M s ., \mathrm{XIX}, 626-62 i, \mathrm{XX}, 14 i-148$.

2 Ibid., XXI, 494, 610.

${ }^{3}$ Council Journals, $1 /$ s.. XV, 198-200, 209-210, 222-224.

+ Ibid., 341 . 
equip four troops of rangers, each consisting of a captain, lieutenant, and twenty men, in addition to Indian guides.' They were commanded by Captains John Fairchild, Roger Gibson, James McPherson, and Christian Minnick, and remained in service for four months. ${ }^{2}$

Scarcely any question of importance ever came before the assembly that they did not in some way encroach upon the powers of the governor and council. The appointment and equipment of rangers was no exception. A resolution of February 7, 1755, provided for a troop of fifty men to range the country between the Broad and Savamnah rivers. Not only were the numbers and pay of the men specified, but a certain William Gray was recommended for captain. About the same time, a committee report on the boundary dispute with North Carolina was sent to the governor. George Hunter and John Pearson were recommended as fit persons to make the survey. ${ }^{3}$

In a message of March 5, Governor Glen severely reproved the assembly for thus interfering in matters purely executive. He stated that he would appoint Hunter and Pearson, as they were well qualified for the work, but added that he must express his surprise at their uniform practice of naming every person to be employed in the public service. Passing over Gray, however, he commissioned Captain Francis to lead the rangers. The house objected and declared that they

${ }^{1}$ Com. House Journals, Ms., XXVI, 337-339, 461, 493.

2 Ibid., XXVII, 479.

3lbid., XXX, 223-224, 228-229, 276-278, 305. 
had provided such high pay for the captain with the express purpose of inducing Mr. Gray to accept. They requested as a favor that the governor would reconsider his action. Glen replied that, as they had used the words request and favor, he would recall Francis' commission and make out one for Gray. The assembly then returned him sincere thanks for granting their request.

The troop was probably not raised at all, since no provision was made for it in the estimates for the next two years. Two small troops were enlisted under Captains Fairchild and Hunt in 1759 with orders to range the country between the Broad and Saluda rivers. ${ }^{2}$

When the war with the Cherokees began, the assembly resolved, in February, 1760, to provide for seven troops of rangers of seventy-five men each, to be continued in the pay of the province until July $1 .^{3} \quad$ The enlistment was almost completed by April 5. The commanders were Captains Grinnan, Brown, Watts, Pearson, Russel, Bosher, and McNeal. ${ }^{4}$ A few months later, Major William Thomson was appointed major commandant of the entire force. ${ }^{5} \quad$ An eighth troop was added in January, 1761 , forming a regiment of six hundred men. ${ }^{6}$ Continued in service until October 1,1761 , they took part in the Indian campaigns of Colonels Montgomery and Grant. The number of troops was reduced to four on

1 Com. House Journals, Ms., 285-292, 305, 312-313.

2 Ibid., XXXIII, Part I, 38-39.

Ibid., 69-70.

IS. Car. Gazette, No. 1338, April 7, 1760.

5 Com. House Journals, Ms., XXXIII, Part II, 13.

6 Ibid., 24 ; S. Car. Gazette, No. 1382, January 24, 1761. 
October 1, 1761, to two on April 1, 1762, and the remainder were disbanded, July $1,1762 .{ }^{1}$

In the summer of 1764 , a troop of twenty men was enlisted under Captain Patrick Calhoun to range for six months around the Long Canes settlement in what is now Abbeville county. ${ }^{2}$ This was the last body of rangers in the pay of the province until the Revolution. In consequence of an uprising of the Creeks in Georgia, the assembly resolved, March 10, 1774, to raise three troops of seventy-five men each and send them to the aid of the Georgians. A bill to that effect was rejected by the council. ${ }^{3}$

\section{Provincial Navy}

A study of the defenses of South Carolina would be incomplete were mention not made of the navy. The term may seem too dignified to be applied to crude scout boats and galleys, but, whatever name may be used, the fact remains that they performed a very useful service for the province.

The beginning of the provincial navy dates from 1713. On December 18 of that year, there was passed "An Act for appointing two Scout Canoes, and providing necessaries for the same." One canoe, manned by two white men and three Indians, was to cruise between Port Royal and St. Augustine; the other, manned by two white men and two Indians, between Port Royal and Stono. Their principal duties were to capture

${ }^{1}$ Com. House Journals, Ms., XXXIV, 254, 267-268, XXXV, 44, 48.

2 Ibid., XXXVI, 54, XXXVII, 107. Patrick Calhoun was the father of John C. Calhoun.

3 Ibid., XXXIX, 116, 166. 
runaway slaves and to keep a lookout for French and Spanish warships. ${ }^{1}$

These boats were kept continually in service until September, 1736; their use was then discontinued for two year's, and they were again employed until after the peace of $1763 .^{2}$ No provision was made for them in the anmual estimates after 1764 and shortly after that date the boats mere sold and the system given up entirely. ${ }^{3}$

By an act of 1723 , the crews were increased to seven men each, of whom the commander received fifteen pounds per month and the men six, in addition to prorisions and ammunition. ${ }^{4}$ Their numbers were still further increased later on. In the estimates for 17414., provision was made for two commanders and twentythree men, for the year $175 \overline{7}-58$, two commanders and twentr-two men, and for the year 1763 , two commander's and twenty-four men. ${ }^{5}$

The Spanish war of $17+0-42$ resulted in some additions to the prorincial fleet. The assembly passed a resolution, December 13, 1740 , to provide for the building of two half galleys." John Yerworth, shipwright, did the work for $£ 2,400$ currener, and $£ 600$ more was appropriated to fit them out. ${ }^{7}$ From the places at which

1 Statutes, II, 60 $\overrightarrow{-}-609$. They are called scout canoes in this act, but in subsequent acts are termed scout boats.

${ }^{2}$ Com. House Journals, IIs., IX, 506, X. 24, 344: Statutes, III, 533539.

${ }^{3}$ Com. House Journals, Hs., XXXVI, 205, XXXVII, 108, 408.

Statutes, III, 180-181.

${ }^{5}$ Ibid., IT, 68, 202; Com. House Journals, Hs., XVII, 244.

${ }^{6}$ Com. House Journals, Hs., XIV, 39.

I Ibid., 234-235. 
they were stationed, they were known respectively as the Charleston galley and the Beaufort galler. They formed part of the fleet sent to Georgia in 1742 to aid in repelling the invasion of the Spaniards from St. Augustine. In this emergency, an embargo was laid upon all the ships in Charleston harbor and many of them were pressed into service. ${ }^{1}$ The Beaufort galley and the Flamborough man-of-war were ordered to proceed to Georgia at once. ${ }^{2}$ The Charleston galley, then lying at Dorchester, was hastily brought down and fitted for use. ${ }^{3} \quad$ Volunteers were called for and bounties were offered. Finally, press warrants were issued and seamen were compelled to serve. A day of fasting and prayer was appointed. ${ }^{4}$ The fleet, which sailed July 18, 1742, under the command of Captain Charles Hardy of His Majesty's ship, the Rye, was the largest that the province ever had under sail at one time. It was composed partly of royal, partly of provincial vessels. Of the king's ships of war there were the Rye, Captain Hardy, twenty-two great guns, one hundred and sixty men; the Flamborough, Captain Hamor, twenty-two great guns, one hundred and fifty men; a swift sloop, Captain Bladwell, eight great guns, twelve swivel, ninety men; and the Hauk sloop, eight great guns, twelve swivel, ninety men. The provincial ships and vessels were the Success, Captain Thompson, twentytwo great guns, twelve swivel, one hundred and ten men; the brig Carolina, Captain Murray, ten great

${ }^{3}$ Public Records, Extra, Ifs, III, 69.

2 Ibid., 70.

Itid., 65, 69, 8--83, s5.

Itid., S5, 91-92, 108-109. 
guns, ten swivel, seventy men; the prize snow, St. Juan Baptista, Captain Barrett, ten great guns, twelve swivel, eighty-five men; the Charleston galley, Captain Lyford, six great guns, ten swivel, sixty-five men; the Beaufort galley, Captain Gibson, eight great guns, sixty men; the schooner Ranger, Captain Davis, twelve great guns, twelve swivel, eighty men; a sloop, Captain Chapman, ten great guns, ten swivel, eighty-two men; and a schooner, Captain Braddock, six great guns, twelve swivel, fifty men. Altogether there were one hundred and forty-four large guns, one hundred and two swivel, and one thousand and ninety-two men. ${ }^{1}$

On account of contrary winds the fleet did not reach St. Simon's Island until the 26th." General Oglethorpe complained bitterly of the delay of the South Carolinians and declared that they did not leave Charleston until after they had received news of the final defeat of the Spaniards. ${ }^{3}$ Still, it seems hardly possible that they would have gone to the expense of fitting up and sending out such a large fleet unless it was to be used for some purpose. Perhaps it was their intention to follow up the victory by an offensive move on St. Augustine. As a matter of fact Captain Hardy had barely reached St. Simon's when he sent word to Charleston of the repulse of the Spanish and of his intention to pursue them. ${ }^{4}$ Instead of doing so, he

I Public Records, Extra, Ms., III, 124. The Flamborough man-of-war and the Beaufort galley returned to Charleston July 17, and the whole fleet set out on the following day. Ibid., 104, 130.

${ }^{2}$ Ibid., 130.

3 Oglethorpe Letters, Collections of Georgia Hist. Soc., III, 125, 139.

4 Public Records, Extra, Ms., III, 125-126. 
returned to Charleston, on July 30, with all of his fleet except the two galleys. The reasons alleged for his change of plan were that the wind was unfavorable and that he thought it better to return and protect the Carolina coast. ' Upon the council's taking him to task, Hardy very curtly replied that he was answerable to no one in South Carolina for his behavior and that he intended to do as he pleased. ${ }^{2}$

Captain Frankland of His Majesty's ship the Rose having arrived from the Bahamas on August 3, the fleet was placed under his command and again ordered out. ${ }^{3}$ Nothing of importance was accomplished, however, and the entire armament returned to Charleston early in September. ${ }^{*}$

The provincial section of the fleet was at once disbanded, as most of the vessels were merchantmen which had been pressed into service. The crews of the two galleys were reduced to ten men each and they were stationed at Beaufort until the middle of November. Captain Lyford continued in command of the Charleston galley, while Captain David Cutler Braddock took Captain Gibson's place on the Beaufort galley. ${ }^{5}$

The crews were soon increased to a captain, gunner, boatswain, and twenty-eight men each. The Charleston boat returned to its station, and was kept in the public service until its destruction in the harbor by a

1 Public Records, Extra, Ms., III, 127.

2 Ibid., 131-134.

${ }^{3}$ Ibid., 135-138.

4 Ibid., 189.

5 Com. House Journals, Ms., XVIII, 63, 754. 
squall on the morning of April 8, 1744.' The Beaufort vessel was put out of commission and its men discharged, December 25,1747 , in consequence of a presentment by the Charleston grand jury that its further maintenance was an unnecessary expense to the public. ${ }^{2}$

\section{Independent Companies}

The province was further protected by independent companies of troops paid by the home government, and usually sent out from England. In May, 1721, a company consisting of ninety-four men came over with Governor Nicholson. ${ }^{3}$ They were stationed temporarily at Port Royal, while Fort King George was being erected near the mouth of the Altamaha river. ${ }^{4}$ By October, work on the buildings had so far progressed that two officers and forty-five men were transferred there. ${ }^{5}$ The remainder of the company followed them early the next year. The barracks at Port Royal were torn down and removed to the new outpost. ${ }^{6}$ Many of the men died in becoming acclimated and Governor Nicholson was soon under the necessity of sending to England for recruits. ${ }^{7}$

${ }^{1}$ Com. House Journals, Ms., XIX, 366; Council Journals, Ms., XI, $195,253-257$.

2Com. House Journals, Ms., XXI, 156, 403, XXII, 733, XXXIII, 681 ; Council Joumals, $\mathrm{Hs}$., $\mathrm{XT}, 63, \mathrm{82}$.

${ }^{3}$ Public Records, Ifs., IX, 45, 61; Public Records, Extra, Mss., I, Part I, 93.

4Com. House Journals, Ms., V, 519.

5 Public Records Extra, Ms., I, Part I, 129.

${ }^{6}$ Ibid., 193; Council Journals, Ms., II, 4.

i Public Records, Extra, Ms., I, Part I, 193; Com. House Journals, Hs., VI, si. 
Fort King George was destroyed by fire in January, 1726. ${ }^{\mathrm{I}}$ Provision was then made for the construction of temporary barracks and the troops remained there until September, 1727. Then, on the order of the general assembly, they were again sent back to Port Royal. ${ }^{2} \quad$ The Beaufort people complained that they destroyed the woods and stole everything they could lay hands on. Nevertheless they were kept there until removed to Georgia in $1736 .^{3}$

There were no independent troops in the province for several years thereafter. Finally, on June 3, 1742, the assembly drew up a petition to be presented to the king. After stating that the French had erected a chain of forts from Canada to the Gulf of Mexico and pointing out the danger to which the province was thus exposed, they begged His Majesty to send out three companies, to be stationed at Forts Johnson, Moore, and Frederick, and to be subject to the orders of the governor.* In a committee report adopted about the same time, the assembly agreed to give some additional pay to the officers and men, provided they were placed under the sole direction of the governor and stationed at the posts mentioned in the petition. ${ }^{5}$

Attorney-General James Abercrombie and Captain William Livingstone offered their services in solieiting the petition without expecting any allowance or re-

I Public Records, 1Is., XI, 287.

2 Ibid., XII, 239; Council Journals, Ms., IV, 65.

${ }^{3}$ Council Journals, 1 s., IV, 171, 198, VI, 202.

4 Com. House Journals, Ms., XVII, 454-459.

ธIbid., 395-396. 
ward. ${ }^{\prime}$ A few months later they were joined by Colonel Alexander Vanderdussen, whose private affairs called him to London. ${ }^{2}$ Owing to the amount of red tape in the British official system, it was three years before the petition was taken under serious consideration. Finally, it was decided to send over the three companies under the command of Vanderdussen, who was commissioned lieutenant-colonel and captain of one of the companies. ${ }^{3} \quad$ The Gazette of January 25, 1746, announced that Vanderdussen and Captains Pascal Nelson and Robert Hudson had arrived on the transport Pelican, three days before, with sixty recruits and noncommissioned officers. The remainder of the men were to be raised in the northern colonies, whither recruiting officers had already been sent.

The assembly at once resolved to ertet barracks in Charleston and to enlarge those at Fort Johnson for the use of the troops. ${ }^{4}$ One company was stationed at Fort Frederick, Port Royal, another in Charleston, and the third was divided between Fort Johnson and Fort Moore. ${ }^{5} \quad$ The muster rolls on January 1, 1748, showed that Captain Nelson's company contained one hundred and two officers and men, Colonel Vanderdussen's one

1 Council Journals, Ms., VIII, 77-80.

2 Ibid., 263-264; Public Records, Ms., XX, 597.

s Council Joumals, Ms., XIV, Part II, 47. Col. Vanderdussen seems to have made a good inpression in London, for he was appointed a member of the council, May 28, 1746. Public Records, Ms., XXII, 160161.

1 Com. Housc Journals, Ms., XXI, 314-316.

${ }^{5}$ Public Records, $1 / s$., XXII, 276. 
hundred and twelve, and Captain Hodgson's ${ }^{1}$ ninetyone. The total amount expended by the province as additional pay for the year $17+7-48$ was $£ 7060: 10: 6$. $^{2}$

One of the companies was disbanded in $1752,{ }^{3}$ but was evidently reorganized shortly afterwards. Early in 1754 one hundred men were taken from the Charleston barracks and sent to Virginia." The exact date of their return cannot be ascertained, but in 1759 all three companies were in the province. ${ }^{5}$

In a letter to the Earl of Halifax, dated April 13, 1764, General Gage stated that the three independent companies in South Carolina had just been disbanded and their place taken by three companies of the first batallion of the Royal American Regiment. The pressure from the French and Spanish having been removed, the South Carolinians were no longer glad to see British troops and refused to give them the extra pay and supplies which they had voted to the independent companies. ${ }^{6} \quad$ These men were under the command of Captain Richard Phillips. ${ }^{7}$ Regular troops were stationed in the province from time to time until the Revolution, but they were no longer welcome and only on rare occasions did the assembly condescend to give them any assistance. ${ }^{8}$

1 Probably the Captain Hudson mentioned in the Gazette. Hodgson is more likely the correct form.

${ }^{2}$ Com. House Journals, Ms., XXIII, 146-148.

3 llid., XXVII, 415.

4 Ibid., XXIX, 309-310, 450-451; Publie Records, Ms., XXVI, 10.

5 Com. House Journals, $1 /$ s., XXXIV, 74.

6 New York Col. Doc., VII, 619.

'S. Car. Gazette, No. 1600, September 7, 1765.

: Public Becords, Ms., XXXI, 413. 


\section{Coast Defenses}

The first colonists had no sooner settled on the west bank of the Ashley than they began to construct fortifications. Governor West wrote to Lord Ashley, March 2,1671 , that thirty acres had been cleared and palisades erected to protect the settlement from the Indians. ${ }^{1}$

In 1680, the colony moved across to the neck of land between the Ashley and Cooper rivers. The town as then laid out consisted of a narrow strip of land along the Cooper river front, bounded on the west by the present Meeting street, and on the north and south by creeks extending along what are now Market and Water streets. $^{2}$

The earliest statutes on the subject of fortifications are lost. Walls and trenches were at once constructed, but they were doubtless very weak and had to be frequently repaired. When Governor Archdale came out in 1695, he was instructed to fortify the town and grant it a charter. The work then begun was continued by his successors, Deputy Governor Blake and Governor's Moore and Johnson. In 1704, the fortifications consisted of six bastions, two half-moons or ravelins, and a line of palisades and trenches. On the Cooper river side were Craven's bastion, at the extreme northeast near the foot of the present Market street; a half-moon near the end of Broad street; Granville's bastion just north of the creek that ran throngh Water street; and Blake's bastion on an island at the mouth of the creek. Along the northern bank of the creek a line of palisades

1 Shaftesbury Papers, s. Car. His. Soc. Col., V, 267.

2 J. J. Pringle Smith in Charleston Year Book, 1880, 242-243. 
and entrenchments extended to Meeting street at its intersection with Tradd, up Meeting to the neighborhood of Cumberland, and thence across to Craven's bastion at the Market street wharf. At the intersection of Church street and Stoll's alley was Ashley's bastion; of Tradd and Meeting, Colleton's bastion; of Broad and Meeting, Johnson's covered half-moon; and at the extreme northwest, at the corner of Cumberland and Meeting, Carteret's bastion. ${ }^{1}$

The walls were evidently very weak, for an act of November 4, 1704, stated that some evil-disposed persons had been climbing over and breaking them down. A penalty of fining or whipping was provided for all who scaled the walls or went down into the trenches. ${ }^{2}$ As a result of this weakness, repairs had continually to be made. Laws for that purpose were enacted in $1707,1714,1719,1721,1725$, and at various other times. ${ }^{3}$

In addition to the walls, moats, and bastions, Charleston was further protected by a fort at the entrance to the harbor. Built in 1708 at the extreme east end of James's Island, it was at first known as the fort on Windmill Point, but was later called Fort Jolnson. A guard of two officers and twelve men was stationed there. ${ }^{4}$

The town soon began to expand beyond the walls,

1 Oldmixon in Carroll, His. Col. of S. Car., II, 448; McCrady, S. Car. under Prop. Gort., 341-342; Maps in MeCrady, frontispiece, and Charleston Year Book, 1880, op, 242, 1884, frontispiece, 1886, op. 280; Map of Charleston printed by Walker, Evans, and Cogswell Co., 1895.

2 Statutes, VII, 36-37.

${ }^{3}$ Ibid., 43-47, 60-65, 65- 1 , $72-73$, III, 250.

Ibid., II, 328, 333-336. 
especially toward the south and west. There was little or no attempt made to extend the limits of the fortifications, however, until after the Spanish war of 1740-42. A watch-house was erected in White Point Garden at an early date, and, in 1708, intrenchments were thrown up along the point for purposes of defense. ${ }^{1}$

The next move was made in January, 1736, when Gabriel Bernard, a Furopean engineer, was taken into the service of the province. ${ }^{2}$ In accordance with his recommendations, there was passed, May 29, 1736, "An Act for repairing the old and building of new Fortifications for the security and defense of this Province from attacks by Sea, and for appointing Commissioners for carrying on such works: and for continuing New Church Street and Little Street to Ashley River.", 3 As this law has not been preserved, we can only infer some of its provisions from the title and from various committee reports. Bernard was emplored as engineer at a salary of seven hundred pounds per annum. Church street was continued from Vanderhorst creek (Tater street) to South Battery. A curtain line of brick or stone was to be constructed along the bay, and the front between White Point and Vanderhorst creek filled up. ${ }^{4} \quad$ Very little was done under this act beyond the erection of a battery in White Point Garden at the

1 Statutes, II, 328.

2 Council Journals, $1 / s$., VI, 170-171, 317. Tradition says that he was an uncle of Rousseau. Charleston Year Book, 1880, 255-256.

statutes, III, 436. Title only.

'Council Journals, Ms., VI, 317, VII, 11 ; Com. House Journals, Ms., IX, 554-5ร5. There was a bridge across the creek erected by Colonel 1 anderhorst. 
foot of Church street, which was called Broughton's battery in honor of the lieutenant-governor.'

The Carolinians, as we have seen, were badly frightened in the summer of $17+2$ by an incursion of the Spaniards into Georgia. On July 7, the assembly resolved to provide means for putting Cliarleston in the best possible posture of defense. Colonel Othniel Beale was employed to draw up plans for fortifying the southern and lower eastern portions of the town. Fortifications were hastily constructed of cedar posts from Vanderhorst creek (Water street) to Broughton's battery, perhaps a little to the west of the present East Battery, and from there "to the point at the landing" on Conseiller's creek," probably near the foot of Gibbes street. Altogether about six thousand pounds were expended. ${ }^{2}$

As soon as the immediate danger was over, the zeal of the assembly perceptibly cooled. After making complaints of the heavy expense, they finally refused outright to make any further appropriations until a capable engineer could be secured to draw up plans. Governor Glen was requested to send to the Bahamas for engineer Bruce. ${ }^{3}$ This was done, and Captain Bruce arrived in Charleston early in January, 1745. After

I I can find no direct evidence that this battery was constructed in 1736-37, but we may infer as much from the fact that it is often mentioned in the journals after, but never before, that date. Furthermore, its name would indicate that it was erected during the administration of Lieutenant-Governor Broughton, 1735-37.

2 Council Journals, $1 / s$. VIII, 143-144, 378, X, 146-147, 152-153, 167-168, 236, XI, 207, 260, 269-270; Public Records, Hs., XXI, 17-28.

IIbid., XI, 388. 
looking round for a few days, he made a report to the governor and council calling attention to some weak points in the defenses which had hitherto been overlooked. He said that Charleston was strongly defended by nature on all sides except the northern, and suggested that the neck should be fortified at once. The bar was a great security and Fort Johnson commanded the usual entrance to the harbor. There was another entrance, however, by way of Hog Island creek. To protect this he recommended the erection of a battery on the marsh land opposite the curtain line, to be in the shape of a horseshoe with the open end toward Charleston. ${ }^{1}$ The report was favorably received, and Captain Bruce drew up two plans for a citadel, to be located on the upper neck midway between the Ashley and the Cooper. One was for a large citadel, 4,592 feet in circumference with four bastions, the other for a smaller one, 3,760 feet in circumference with two bastions and two demi-bastions. ${ }^{2}$ These plans had to be given up as the expense was greater than the province could bear. ${ }^{3}$

The recommendations made in the report were, however, strictly adhered to. An act, ratified May 25, 1745 , ordered the commissioners of the fortifications to cut a moat through land and marsh from Craven's bastion to the Charleston workhouse, said moat to be thirtysix feet wide, as deep as possible, and commanded by one or two bastions. On the marsh south of Hog Island

${ }^{1}$ Council Journals, Ms., XIV, 88-90.

${ }^{2}$ Ibid., 127-128.

3Ibid., XIII, 250 . 
creek-the site of Castle Pinckney-there was to be erected a horseshoe battery of not more than sixteen cannon. The total expense was estimated at $£ 20,000$ currency, to be paid out of the fortification fund. As there was not enough money on hand belonging to that fund $£ 20,000$ in fortification orders were to be issued, receivable in payment of all duties appropriated for fortifications. ${ }^{1}$

Work was begun at once. The commissioners of the fortifications reported, February 22, 1746, that the moat and rampart across the neck were almost completed. The law had provided for not more than two bastions, but they regarded these as insufficient and erected three. Four or five were really needed. ${ }^{2}$ The assembly approved the work and resolved that two more bastions or ravelins should be constructed, one of them at the high road, that is at King street. ${ }^{3}$

As near as we can judge from the limited data at hand, this line of fortifications extended from Market street wharf to the marshes of the Ashley river, striking the present Colonial lake about midway between Queen and Beaufain streets. King street was crossed at Clifford, and Mazyck at Magazine, the workhouse being on the southwest corner of Mazyck and Magazine.

The horseshoe battery on the marsh was probably not erected at this time, as the expense of the other work was so great. Its estimated cost was four thousand pounds. ${ }^{4}$

${ }^{1}$ Statutes, III, 653-656.

${ }^{2}$ Council Journals, Ms., XIV, Part II, 27-29.

${ }^{3}$ Com. House Journals, I/s., XXI, 357.

"Ilid., XXVII, 439; Council Joumals, Ms., XV, $15 \mathrm{~s}$. 
For the next few years little was done beyond keeping the fortifications in repair. This work was entrusted to a special board of commissioners containing some eight or ten members. With the approbation of the governor and council, they were empowered to make contracts and purchase lands for erecting forts and batteries in such places as might be necessary. There was a special fund at their disposal derived from an extra import duty on rum, Madeira wine, sugar, molasses, and a few other articles. It varied in amount from $£ 7,000$ to $£ 9,000$ per annum until 1751 , when the general duty act fixed it at $£ 5,000 .{ }^{1}$

Governor Glen looked upon the appointment of such commissioners as an encroachment upon his duties as chief executive. He attempted to destroy the board gradually by refusing to fill vacancies as they occurred. A message from the assembly, dated Jannary 23, 1752, called his attention to the ruinous condition of the fortifications and urged him to complete the board at once. No attention was paid to this, nor to another message of the same character which was sent up on March 11. Finally, a third message was sent on April 29, complaining that their requests had been disregarded and again urging that the vacancies should be filled. They stated further that they had heard that there were over twelve thousand pounds in the fortification fund, and recommended that it should be used to repair Forts Frederick and Johnson. ${ }^{2}$

1 Council Journals, Ms., XV, 158; Com. House Journals, Ms., XXVI, 61 ; Public Records, Ms., XXV, 110; Statutes, III, 749.

${ }^{2}$ Com. House Journals, Ms., XXVII, 139-140, 233, 400-401. 
In his reply, made a few days later, Glen called attention first to the weak condition of the fortifications, notwithstanding the great amount of money that had been expended on them. Before beginning repairs, a skillful engineer should be called upon to draw up plans, and he suggested that there was now such a gentleman in the province whom they could employ. Coming to the request to fill up the vacancies on the board, he declared that such establishments as commissioners of fortifications were an encroachment on His Majesty's authority, and that he would make no appointments until he had consulted with his council. ${ }^{1}$

The skillful engineer referred to by the governor was Mr. William Gerald De Brahm, formerly a captain engineer in the service of the emperor Charles VI, but at that time a resident of Georgia. ${ }^{2}$ He was highly recommended by Count Seckendorf, under whom he had served. ${ }^{3} \quad$ With the advice of his council, Glen had sent to Georgia for him to come over and draw up plans for repairing the fortifications.

The assembly refused to consent to the employment of De Brahm on the ground that it would be unsafe to allow a foreigner to sound the channel and make plans of the fortifications. As for the vacancies on the board of commissioners, they expressed surprise that the governor should dare to say that a law of the province encroached on His Majesty's prerogative. At any rate,

${ }^{1}$ Com. Honse Journals, Ms., XXVII, 434-440.

${ }^{2}$ S. Car. Gazette, No. 1141, May 6, 1756.

${ }^{3}$ Publie Records, 11 s., $\mathrm{XXV}, 120$. 
the law was in force until repealed by the king and could not legally be dispensed with by the governor. ${ }^{1}$

Two days later, that is on May 16, the assembly adjourned to Norember 21. The province was visited by a violent hurricane, on September 15, which destroyed houses and bridges, entirely demolished the fortifications, and caused considerable loss of life. ${ }^{2}$ The assembly was hastily called together to take measures for the relief of the sufferers.

The necessity of rebuilding the fortifications renewed the old controrersy. The assembly insisted that the membership of the board of commissioners should be completed and that the work of reconstruction should begin at once. Glen, on the other hand, declared that the first step should be the employment of a competent engineer to draw up plans. The old fortifications had been built in piecemeal fashion and were always weak; now was an opportunity to begin anew according to some definite system. The dispute dragged on for several weeks. The assembly declared that, if an engineer was necessary, they would prefer to employ Colonel Beale rather than a foreigner, whose recommendations were written in the French language. Glen yielded so far as to appoint the commissioner's of the fortifications, but the dispute in regard to De Brahm caused a delay of nearly three years in the systematic repairing and

${ }^{1}$ Com. House Journals, Ms., XXYII, 546-550.

2Ilid., 5S1. For a detailed account of this storm, one of the sererest ever known in Charleston, see note to Ramses, His. of S. Car., II, $3: 0-326$. 
rebuilding of the fortifications. ${ }^{1} \quad$ Meanwhile the commissioners were spending the $£ 5,000$ per annum belonging to the fortification fund in making some haphazard repairs. The damage done by the hurricane, as well as the subsequent repairs, are described in a report of February 4, 1755. Craven's bastion (at Market street) had been almost entirely washed away, but had since been repaired, with the exception of the parapet, and now was equipped with eight twelve-pound cannon. The Half Moon (at Broad street) had a platform in fairly good condition, with five large and two small cannon lying upon it. At and around Granville's bastion (at Water street) were twenty-five new and twelve old cannon. A small bastion between Granville's bastion and Broughton's battery (probably at Church and Soutl Battery streets) had been badly damaged, but the brick work had since been repaired and the foundation well secured with ballast stones. No parapet had yet been raised or platform laid. There were seventeen good cannon mounted and twelve old ones lying on skids. The bastion at the foot of King street had been in ruins since the hurricane. Tipper's bastion, a little to the west (about the end of Legaré street), and the bastion near Conseiller's creek (about the end of Gibbes street) were in the same condition. ${ }^{2}$ The cedar palisades extending from Conseiller's creek round to Gran-

${ }^{1}$ Com. House Journals, Ms., XXVII, 591, 611-612, XXVIII, 28-31, 86-92, 108, 110-117, XXX, 531, 623-624; S. Car. Gazette, No. 1141, May 6, 1756 ; Public Records, Ms., XXV, 106-115, XXXII, 386.

${ }^{2}$ I cannot ascertain the exact dates of the construction of these smaller bastions. They were probably erected in 1742-43 under the superintendence of Colonel Beale. 
ville's bastion were almost all washed away, only a few posts being left between Tipper's and Conseiller's bastions. The rampart across the north end of the town, being built of loose sandy soil, had suffered very greatly, much of it having fallen into the moat alongside it. The bastions and ravelins along this line were also in a ruinous condition. In Fort Johnson the platform of the lower battery was destroyed and several heavy cannon lost. The upper fort also suffered some, but it had since been repaired and thirteen cannon were now mounted. ${ }^{1}$

Taking this report under consideration, the assembly forgot their old animosity toward De Brahm and requested Governor Glen to send for him. Arriving in Charleston early in April, 1755, he made a careful examination of the town and harbor and then presented elaborate plans for fortifying the town on all sides. Lieutenant-Gorernor Bull states that the scheme was laid aside becanse it would have kept De Brahm long in the pay of the province, but would have been of little real value in defending the town. ${ }^{2}$ Captain De Brahm had to limit his energies to rebuilding the curtain line from Vanderhorst creek (Water street) around the battery to the land of Thomas Shubrick, in the neighborhood of Gibbes street. It doubtless followed the line of Colonel Beale's cedar palisades. The work was eighteen months in building and over $£ 30,000$ was expended. ${ }^{3}$ A report of a committee, dated March 10,

${ }^{1}$ Com. House Journals, 11 s.. XXX, 197-203.

2 Ibid., 433-434, 524-525; Public Records, Us., XXXII, 386.

3Ibid., XXXI, Part I, 118-119; Public Records, Hs., XXVII, 61, 179. 
1756 , intimates that the method of construction was unsatisfactory. The walls, according to the report, consisted of fascines laid on the loose sand without any foundation or security against the waves and violent rains, except a few stones piled on the outside. ${ }^{1}$

Early in 1757, Governor Lyttleton wrote to Lord Loudon, then in command of the British forces in America, asking for an experienced engineer. He immediately sent Captain Hesse to Charleston. Lieutenant-Colonel Bouquet, commander of the Royal American troops, who arrived in the province in June, 1757 , was also well versed in engineering. ${ }^{2}$ Plans were formed for building a new line of defenses across the neck. ${ }^{3} \quad \mathrm{By}$ a majority of only two votes in the assembly, an act was passed, July 6,1757 , appropriating $£ 44,300$ currency to carry on the work. Fortification orders were issued, to be redeemed gradually by additional import duties on wines, rum, biscuit, and flour. ${ }^{*}$ All the orders were called in and destroyed by June 2, 1761, as a law was then enacted for repealing the clause for the levy of an additional duty..$^{5}$ The work was partially carried out, but never completed. ${ }^{6}$

The peace of 1763 removed all danger from the French, Spanish, and Indians. Accordingly, cannons were dismounted, carriages housed, and the fortifica-

1 Com. House Journals, Ms., XXXI, Part I, 119.

2 Ibid., XXXI, Part II, 143; S. Car. Gazette, No. 1195, June 23, 1757.

${ }^{3}$ Public Records, Ms., XXXII, 386-387.

4 Ibid., XXVII, 285, 288; Statutcs, IV, 45. $£ 44,300$ currency was

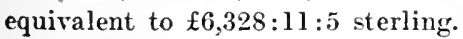

5 Statutes, IV, 150-151.

${ }^{6}$ Public Records, Ms., XXXII, 387. 
tions generally neglected until the outbreak of the Revolution. ${ }^{1}$

\section{Frontier Defenses}

Frequent invasions of the Spanish and Indians made the protection of the frontiers an absolute necessity. Some attention has already been paid to this subject in discussing rangers, independent companies, and scout boats. The first fort erected in the province was Fort Johnson, in 1708. That, being designed for the special protection of the town rather than as a frontier defense, has been considered in connection with the coast defenses. The earliest frontier outposts were those established during and just after the war with the Yemassees in 1715. On March $\bar{\gamma}, 1716$, the assembly resolved that garrisons should be established at seven different points. The largest of these were at Port Royal and at Savanno Town, which soon received the name of Fort Moore. ${ }^{2}$ Fort Moore was situated on the eastern bank of the Savannah river, six miles below Augusta, in what afterwards became New Windsor township. ${ }^{3}$ Later in the year Fort Congrees - or Congarees - was erected on the Congaree river just below the present site of Columbia. it In 1716, forty-two men and officers were stationed at Fort Moore, twenty-seven at Port Royal, ${ }^{5}$ and perhaps

1 Public Records, Hs., XXXII, 387; Journal of a Voyage to Charlestown in So. Carolina by Pelatiah Webster in 1765, Southern History Association Publications, II, 135.

${ }^{2}$ Com. House Journals, Hs., V, 27 .

${ }^{3}$ Council Journals, IIs., XIV, 242-245; Public Records, IIs., XVIII, 242.

1 Com. Housc Journals, Ms., V, 111, 151; MeCrady, S. Car. under Royal Govt., 299.

5 Ibid., V, 166. 
about the latter number at the Congarees. As soon as the danger from the Indians passed away, the garrisons were reduced and the smaller posts abandoned. There were, in 1720, eight or ten small cannon at Port Royal and five or six at each of the other two forts. ${ }^{1}$

In 1721, Fort King George, or Fort Altamaha, was constructed by Colonel John Barnwell near the mouth of the Altamaha river on the extreme southwestern frontier. It was garrisoned by His Majesty's independent company, which came over with Governor Nicholson in 1721. ${ }^{2}$ As we have already seen, this fort was destroyed by fire in January, 1726. Temporary barracks for the troops were erected and they were kept there until September, 1727, when the place was entirely abandoned. ${ }^{3}$

The next fort erected was at a place called Pallachocola Old Town. It was probably situated on the Savannah river, just above the Florida Central and Peninsula railroad bridge, in what is now Effingham county, Georgia. A small palisade fort was constructed under an act of February 23, 1723..$^{*}$ A garrison was maintained there until 1735 , when it was dismissed and the fort was turned over to the Georgia authorities. $^{5}$

1 Public Records, Hs., VIII, 68.

${ }_{2}$ Public Records, Extra, Ms., I, Part I, 17, 129, 193; Com. House Journals, Ms., V, 533-534, VI, 71-72, 86, 87; S. Car. His. Soc. Col., II, 148.

${ }^{3}$ Public Records, Is., XI, 287, XII, 239; Council Journals, Ms., IV, 65.

Statutes, III, 179-180.

5 Council Journals, Hs., VI, 70, 118-119. 
Immediately after his arrival in the province in December, 1730, Governor Johnson tried to induce the assembly to rebuild Fort King George. They roted $£ 800$, to be used jointly for that purpose and for constructing a new fort at Port Royal. The whole amount was expended on the Port Royal fort, which received the name of Fort Frederick. Governor Glen says that it was injudiciously situated and poorly constructed, being made of oyster shells. By 1743 it had gone to ruin and was soon after abandoned. ${ }^{1}$

Fort Moore was at this time the most important outpost, though the gradual growth of Georgia rendered it less and less necessary. Its garrison was reduced in 1735 and 1739 , temporarily increased in 1743 , and again reduced in $1745 .{ }^{2}$ The walls and barracks were in a ruinous condition by this time, and, as war with the French was coming on, it was decided to rebuild. The work was completed in 1747 at a cost of $£ 3,000 .^{3}$

The aggressions of the Cherokees soon led to a revival of activity in the building of forts. On October 14, 1753, Governor Glen and a large detachment from His Majesty's independent companies set out for the lower Cherokee country, where they erected a fort, called Prince George in honor of the heir apparent to the British throne. The work was completed and they were back in Charleston by December $11 .^{4}$ The total

1 Public Records, IIs., XV, 38, XVI, 73; Council Journals, ISs., IX, Part II, 60-61, XVI, Part II, 103.

${ }^{2}$ Council Journals, ys., VI, 70, 101, 104, 116, VII, 181, IX, Part II, 61-62, 72, XIV, 242-245, 248.

${ }^{3}$ Ibid., $\mathrm{XV}, 158$.

S. Car. Gazette, No. 1018, December 17, 1753. 
cost was $£ 5,000$ currency for the fort and $£ 700$ for a tract of several thousand acres of land which surrounded it.' This fort was situated on the Keowee river in Pickens county, abont fifteen miles northwest of the town of Pickens. ${ }^{2}$

Three years later a fort was constructed among the upper Cherokees and named Fort Loudon in honor of the commander of the British forces in America. The amount expended on it was about $£ 7,000$ sterling, of which the king furnished $₫ 1,000$ and the province the remainder. ${ }^{3}$ It was located in what is now Loudon county, Tennessee, on the southern bank of the Tennessee river about thirty miles southwest of Knoxville. ${ }^{4}$ During the war with the Cherokees, 1760-61, it was surrounded, its garrison of two hundred men forced to capitulate, and the works were destroyed.

In the winter of 1758-59, work was begun on Fort Lyttleton near Beaufort, Port Royal. ${ }^{6}$ Some delay was caused by the Cherokee war, however, and it was not completed until late in $1762 .^{7}$ It was intended to replace Fort Frederick, which, as we have seen, had long since gone to ruin.

${ }^{1}$ Com. House Journals, Hs., XXIX, 17T. For a discussion in regard to the extent of this purchase, see McCradr, S. Car. under Royal Govt., 307 .

${ }^{2}$ Landrum, Col. and Rev. Hist of Lpper. S. Car., 29; Mill, Statistical Atlas, in office of secretary of state, Columbia.

${ }^{3}$ Com. House Journals, Is., XXXI, Part I, 47-48, 221-222, 227, Part II, 121; Public Records, I/s., XXIII, 318.

4 Ramsay, Amuls of Tennessce, 51.

${ }^{5}$ Com. House Journals, .1/s., XXXIII, Part I, 311, Part II, 6. For a full account of this, see MeCrady S. Car. under Royal Gort., 34i-349.

E Statutes, IV, 98.

'Com. House Journals, Us., XXXY, 80-81. 
The last fort erected during the colonial period was built, 1765-66, on the Savammal river about forty-five miles above Augusta, opposite the mouth of the Broad river, in the lower part of what is now Abbeville county. It was constructed of stone at a cost of $£ 1,000$ sterling and was called Fort Charlotte in honor of Her Majesty, the queen. ${ }^{1}$

\section{Indian Relations}

The Indians were in many respects the most powerful, the most dangerons, and the most persistent enemies with whom the Carolinians had to deal. As long as the French and Spanish had a foothold on this continent, the primary object of provincial diplomacy was to secure the aid, or at least the neutrality of their Indian neighbors. Moreover, a large and lucrative trade was carried on with them, which for a long time constituted one of the chief sources of wealth. Consequently, we find the colonists regulating trade, distributing presents, and doing all in their power to preserve peace. A discussion of the general defenses of the province would, therefore, be incomplete without some reference to Indian affairs.

The subject is entirely too extensive for anything like a detailed treatment, so a very brief ontline is all that can be given. When the province was first settled, there were some twenty-five or thirty Indian tribes living wholly or partly within the present limits of the state. In 1765 there were only two, though a number of tribes in the surrounding country still gave occasional trouble.

i Com. House Joumals, Hs., XXXVII, Part I, 30, 58, 61, Part II, 233 ; Public Records, Ms., XXX, 250-251. 
The Catawbas dwelt on a reservation of fifteen square miles, situated in the upper valler of the Wateree or Catawba, in what is now York county. They had scarcely one hundred and fifty warriors. The lower Cherokees lived in northern Alabama and Georgia, mostly north of the Broad river, or the 34 th parallel of latitude, in northwestern South Carolina, and in the southern portions of Tennessee and western North Carolina. The upper Cherokee lands lay further to the north and west. In 1765 both branches could bring scarcely two thousand men into the field. The territory of the upper Creeks extended from the Sarannah river, between Broad and Little rivers, indefinitely to the westward. The lower Creeks lived in the valleys of the Chattahoochee and the Flint. In the whole Creek nation there were not more than two thousand men. The Chickasaws roamed the country to the west, and the Choctaws dwelt still further westward. ${ }^{1}$

The treatment of Indian affairs may be divided into two main periods: from 1670 to 1756 they were under the control of the provincial government; from 1756 to the Revolution, under the direct control of the crown. As early as 1677 , dishonest traders had begun to cause trouble, and the Lords Proprietors issued an order forbidding anyone to trade with the Indians except those who obtained special license from their board. ${ }^{2}$ Three years later Governor West and six others were appointed a commission to determine differences and com-

1 Hewatt in Carroll, His. Col. of S. Car., I, 494, and map, frontispiece; Public Records, Ms., XX, 56s-570; Brownell, Indian Races of America, 383-390.

2. Car. His. Soc. Col., I, 101; Public Records, Ms., I, 60-61. 
plaints between the Indians and the English. ${ }^{1} \quad$ A law of 1691 limited traders to a narrow strip along the coast between the Savamnah river and Winyaw Bay."

In $170 \overline{7}$, a board of nine commissioners was appointed to superintend Indian affairs. They were authorized to license traders and require them to give bond for good behavior. Thomas Nairne was employed as resident agent among the Indians, with power to settle all disputes among trader's where the amount involved did not exceed thirty pounds, to arrest traders who were guilty of misdemeanors and send them to Charleston for trial, to take charge of the goods of persons who were committed to prison, and to exercise the powers of a justice of the peace. ${ }^{3}$ This method of controlling Indian affairs was in use from 1707 to 1716 . It may be called the plural commissioner system.

In 1716 , the govermment decided to take the trade out of the hands of private individuals and carry it on for the public benefit. Accordingly, the commissioners were formed into a corporation, with a seal, and with power to hold property and to sue and be sued. They were given an absolute monopoly of the Indian trade, and were authorized to employ agents and factors. Trade was to be carried on from three points, Fort Moore, Fort Congaree, and Winyaw. Each commissioner receired a salary of one hundred and fifty pounds a year and the treasurer thirty pounds extra. The net profits went into the public treasury. ${ }^{4}$

1 S. Car. His. Soc. Col., I, 103.

2 Statutes, II, 66.

${ }^{3}$ Ibid., 309-316.

4 Ibid., 677-680. 
In consequence of numerous complaints, the Lords Proprietors declared this act null and void, July 22, 1718. ${ }^{1}$ On March 20 of the following year, however, the assembly re-established the public trading corporation, but did away with the monopoly feature. Private traders could do business, provided they obtained an annual license from the commissioners and gave a bond of five hundred pounds currency to treat the Indians justly. The commissioners were authorized to refuse licenses to persons whose presence among the Indians they regarded as detrimental to the public safety. There were several severe restrictions imposed on traders, which were almost prohibitive. Thus they were taxed ten per cent. on the ralue of their Indian purchases, presumably to keep up the three trading garrisons, were compelled to pay the clerk of the commissioners a fee of eight pounds for drawing up a license, and were forbidden to trade with any Indians who lived within twenty miles of a garrison. ${ }^{2}$

The system of the public trading corporation, as we may call it, was kept up from 1716 to September 19, 1721. Then the government went out of the trading business, and the old plural commissioner system was restored. Colonel William Bull and Messrs. George Chicken and John Herbert were appointed a board of Indian commissioners, at a salary of three hundred pounds each. They met at Charleston four times a

is. Car. His. Soc. Col., I, 166.

2 Statutes, III, 86-96. These trading garrisons were the same as those provided for in the act of 1716 , except that there was one at Pallachocola Old Town on the Savannah river instead of the one at Winyaw. 
year, in at least a two days' session, for the purpose of granting licenses, giving instructions, and taking bonds. They were instructed to visit the frontier trading posts twice a year and examine the garrisons and stores, to suspend garrison officer's temporarily for misbehavior, to hear and determine complaints of Indians against traders, to adjudge damages, revoke licenses, and perform various other duties. All traders, except those trading with a few neighboring tribes regarded as in the settlement, were required to come in person to Charleston once a year, when the board was in session, for the purpose of taking out licenses and giving bond to obey the instructions of the commissioners. The total license fees amounted to twenty-three pounds. ${ }^{1}$

It was apparently the intention of the government in passing this act to secure for South Carolinians a monopoly of the Indian trade. Virginia traders had for many years been carrying on traffic with the Creeks and Cherokees, who resided within the nominal limits of South Carolina. They were now put to the inconrenience of making an annual journey to Charleston, paying an exorbitant license fee, and giving bond to obey the orders of the Indian commissioners. Mr. John Carter, agent for Virginia in England, appeared before the Board of Trade and tried to secure a disallowance of the law. The whole question was referred by the Board to their special counsel, Mr. Richard West, who made his report on October 25, 1722. He carefully analyzed the act and called particular attention to the high license fees and to the provision requiring all

' Statutes, III, 141-146. 
traders, Virginians as well as Carolinians, to make personal visits to Charleston in order to take out licenses and give bonds to obey the orders of a board which was naturally prejudiced against them. Taking up its historical side, he stated that a similar law of 1711 had been repealed by the proprietors at the command of the Board of Trade. The only difference between the two was that the law of 1711 specifically mentioned Virginia traders, while that of 1721 merely comprehended them in general terms. ${ }^{\prime}$

In spite of this unfavorable report, the home government does not seem to have repealed the law, for its main features were continued in force for many years. An amendment of February 23, 1723, provided for the adoption of a ilew system of control, though various provisions, including that relating to licenses, remained unchanged. The board of commissioners was abolished and their powers and duties were conferred on the governor and any three members of his council. They were authorized to appoint a supervisor to visit the various trading garrisons twice a year and report their condition to the governor, council, and assembly. ${ }^{2}$

This system was kept up for only one year, when it was seen that too much of the time of the governor and council was being taken up with Indian affairs for them to attend to their ordinary duties. A law of February 15, 1724, provided for the appointment of the Honorable James Moore as sole commissioner of Indian

${ }^{1}$ Chalmers, Colonial Opinions, 592-598. For the law of 1711 , see Statutes, II, 357-359.

2 Statutes, III, 184-186. 
affairs, and vested him with all the powers and duties that had been conferred on the board of commissioners by the act of 1721 , and subsequently transferred to the governor and council by the amendment of $1723 .{ }^{1}$

With the exception of a few months in 1751-52, when the governor, council, and a committee of the assembly had charge of Indian affairs, ${ }^{2}$ the single commissioner system was kept up until the crown assumed direct control in 1756. Moore died a few days after his appointment and was succeeded by Colonel George Chicken. ${ }^{3}$ The subsequent commissioners were John Herbert (1731-1733), Tobias Fitch (1733-1734), William Drake (1734-1736?) Childermas Croft (1736-1747), William Pinckney $(1747-1751,1752-1756){ }^{4}$

After the settlement of Georgia, South Carolina received the same treatment in regard to the Indian trade which she had previously meted out to Virginia. A Georgia statute, passed early in 1736 , required all persons trading with the Indians within the bounds of that province to take out licenses at Savannah. A number of South Carolina traders were expelled from the Indian country and their goods were taken from them. ${ }^{5}$ The general assembly of South Carolina was called together by special proclamation on June 23 to consider the matter. ${ }^{6}$ Captain Othniel Beale, Captain

1 Statutes, III, 229-232.

2 Ibid., 754-755, 763-771.

I Ibid., 246; S. Car. His. Soc. Col., I, 279; Council Journals, Ms., II, 262 .

4 Statutes, III, 333, 372, 401, 482, 511, 525, 693, 754-755, 770.

${ }^{5}$ Com. House Journals, Ms., X, 218.

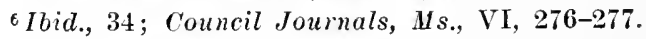


Peter Taylor, and Mr. Charles Pinckney from the -assembly, and Mr. Hammerton from the council, were appointed a committee to go to Savannah and confer with General Oglethorpe.' A temporary agreement was finally reached, but the matter continued to be a subject of controversy for several years. ${ }^{2}$ The law officers of the crown decided in favor of Georgia. In an opinion of July 28, 1737, they declared that a colony could not legally exclude the people of other colonies from trading with the Indians, but to require a license was merely a legal exercise of the power to regulate trade. ${ }^{3}$

The trade acts of South Carolina up to 1736 had gradually grown more and more stringent. The law of 1734, for example, provided for a license fee of eighty pounds currency and required the traders to pay a duty of six pence on each skin or fur traded for. ${ }^{4}$ Georgia offered more liberal terms, and many traders changed their headquarters to Savannah. Two laws were enacted in 1736 for reducing the license fee, taking off the duties and impositions on trade, and indemnifying the traders for certain fines, penalties, and forfeitures. ${ }^{5} \quad$ The old restrictions were never again established, except for a short period in $1762-64$, when trade with the Cherokees was taken into the hands of the public in order to preserve peace. ${ }^{6}$

The relations with the Indians constituted another

${ }^{1}$ Com. House Journals, Ms., $\mathrm{X}, 74,78$.

${ }^{2}$ Ibid., 296-300; See Harris, Memorials of Oglethorpe, 152-157.

${ }^{3}$ Chalmers, Colonial opinions, 591-592.

- Statutes, III, 330, 399-402.

5 Ibid., 448-449, 453.

' Ibid., IV, 168-173, 188-1s9. 
fruitful source of conflict between the governor and assembly. As usual, the lower house took advantage of their control over money bills to usurp functions purely executive in character. They were frequently encouraged to do so by the governor and council. Thus in 1727, when a war with the Yemassees was tilleatened, the assembly was asked to concur with the council in requesting Captain Edward Massey to remove His Majesty's independent company from Fort King George to Port Royal. A few days later committees from both houses met to confer in regard to the details of the proposed campaign. ${ }^{1}$

A still more serious encroachment was made in 1737 . The Spaniards at St. Augustine were trying to incite the Indians to make war on the English. Six thousand pounds were appropriated for an Indian expedition, and provision was made that it should be paid by the treasurer "on orders drawn for the same, by His Honor the Lieutenant-Governor, His Majesty's Honorable Council, and a committee of the Commons House of Assembly, jointly and not otherwise."' Just before adjourning, on March 5, the lower house went still further and resolved that all the members of their house living in Charleston, and such others as might happen to be in town during the recess of the assembly, should join the governor and council in conference respecting any emergencies that might arise and in drawing orders on the public treasurer. ${ }^{3}$

${ }^{1}$ Com. House Journals, Ms., VII, 573-576.

2 Statutes, III, 484.

${ }^{3}$ Council Journals, Ms., VI, 481. 
Having finished the business before them, the assembly adjourned from March 5 to May 16. On March 7 a meeting was held in the council chamber, in which the members of the lower house took part, thirteen of them and two members of the council being present. These meetings were held at intervals until April 2. A number of orders were drawn on the treasurer and various resolutions were adopted in regard to the movement of troops, storing of provisions, and other matters purely military in character. ${ }^{1}$ The council acquiesced in this, though they subsequently declared that to allow the house a share in signing orders on the treasury was directly contrary to His Majesty's instruction directing the governor to take care that no money should be issued but by warrant under his hand. ${ }^{2}$

A third attempt on the part of the assembly to share in the administration of Indian affairs failed, but they succeeded in convincing the governor and council that nothing could be done without their assistance. On March 6, 1752, they requested Governor Glen to lay before them, as soon as possible, all papers relating to Indian affairs which had not yet been communicated to their house. Glen replied that he had ordered such of the documents as might properly come before them to be copied and sent down. The assembly at once informed him that they wished to see all of them and to see the originals, not copies. On his refusal to send them, they resolved that they had a right to see all the papers, and that a reservation of any of them deprived the

${ }^{1}$ Council Journals, Ms., VI, 487-494.

2 Ibid., XIII, 144-145. 
representatives of the people of the means of forming a true judgment of Indian affairs and prevented them from assisting the governor with their advice. ${ }^{1}$

A few days later His Excellency asked the assembly to provide for the expense of sending four or five Catawba Indians to an Indian conference in New York. They replied that they were in the dark in regard to Indian affairs and did not propose to take any steps until they had more information on the subject. Accordingly, they had postponed the matter until the next meeting, when they hoped that the governor would lay the desired papers before them. Glen still refused to give up the papers, and Indian affairs were, as a consequence, sadly neglected. The assembly took occasion to observe that they were seldom informed in regard to such matters unless money was wanted to put into execution some of the governor's schemes. ${ }^{2}$

In the year 1756, the general control of Indian affairs was taken under the direct supervision of the crown, though the regulation of trade was still left to the colonial governments until 1764 . This move was due largely to the zeal and activity of Sir William Johnson of New York. Students of colonial history are familiar with the career of this remarkable man, and all have admired the consummate skill and ability with which he managed the New York Indians. Early in 1755, he was

${ }^{1}$ Com. House Journals, Ms., XXVII, 207, 230, 232, 246-247, 255, $267-268$.

2 Ibid., 293-294, 417. During the previous July several Catawbas under the charge of Col. William Bull, Jr., had been sent to an Indian conference at Albany. Commissioners were also present from Massachusetts Bay and Connecticut. T. Y. Col. Doc., VI, 717-726. 
commissioned by General Braddock, sole superintendent of the affairs of the Six Nations and their allies, and he soon succeeded in bringing order out of chaos. ${ }^{1}$ The success of his work, in contrast with the bungling mismanagement of the old commissioners at Albany, naturally led the home government to take complete control. An outline of the plan adopted is to be found in a paper of January 9, 1756, entitled, "Some Thoughts upon the British Indian Interest in North America more particularly as it relates to the Northern Confederacy commonly called the Six Nations," signed by Peter Wraxall, Secretary for Indian Affairs, and addressed to Sir William Johnson. There was to be a distinct Indian service immediately under the king and supported by an established fund. Two persons of ability and integrity, who were agreeable to the Indians, were to be commissioned by His Majesty to be superintendents of Indian affairs, one for the Six Nations and their allies, to reside in New York, and one for the southern Indians, to reside in South Carolina. They were to correspond regularly with the Board of Trade and receive instructions from them. Indian affairs of a general nature were to be communicated to the commander in chief of His Majesty's forces in America; those affecting New York and South Carolina directly should be submitted to the governors of those provinces. The superintendents were likewise to receive instructions from the said commander in chief, or governors of New York and South Carolina, according to whether the

1 Johnson Manuscripts in Doc. Hist. of Tew York, II, 391; New York Col. Doc., VI, 95广-958, VII, 19. 
matters under consideration were general or local. They were to hold public meetings with the Indians, distribute presents, appoint interpreters and agents, transact all business with the Indians, give each other regular advice of their proceedings, and conduct their administrations upon a uniform system. They were to be members of the council in their respective provinces. $^{1}$

In accordance with this plan, Sir William Johnson was, in 1756, commissioned superintendent for the northern district, including all the provinces north of Tirginia, and Mr. Edmund Atkin for the southern district, including Virginia, North Carolina, South Carolina, and Georgia." In 1762 Atkin was succeeded by Captain John Stuart, whose success with his savage charges was second only to that of Sir William Johnson. ${ }^{3} \quad$ It was largely due to his efforts that the southern Indians supported the mother country during the Revolution. Sir William served as superintendent of the northern district until his death in 1774, when he was succeeded by his son-in-law, Colonel Guy Johnson, who also took an active part in organizing the Indians against the colonists.

The service was extended in 1764 , the powers of the superintendents were increased, and trade was brought more closely under the supervision of the crown. A plan for the future management of Indian affairs,

1 New York Col. Doc., VII, 15-29, especially 26.

2 Ibid., 35, 211-212, 574; Com. House Journals, I/s., XXXII, 223-224.

${ }^{3}$ Com. House Journals, Hs., XXXVIII, 30i-308.

4 Doc. Hist. of New York, II, 5\$2-583; New York Col. Doc., VIII, passim. 
drawn up by the Board of Trade in July of that year, contained forty-three articles. The superintendent of the northern district was to have three deputies, the superintendent of the southern, two. A commissary, an interpreter, and a smith were to reside in each of the southern tribes and at each northern trading post, and act under the immediate orders or directions of the superintendent. The superintendents were to conduct all public affairs relative to the Indians. Gorernors were forbidden to hold general meetings with the Indians without the concurrence of the superintendent, except in emergencies or when the superintendent was in a remote part of the district. In all matters of political importance relating to peace and war, purchase of land, etc., the superintendents were to advise and act in concert with the governors and councils in the various colonies within their districts. For this purpose each superintendent was made councilor extraordinary in every colony of his district. The superintendent or a deputy was required to visit each post or tribe in his district at least once a year in order to examine into the conduct of subordinate officials, hear and redress complaints, and make presents to the Indians. The commissaries were to act as justices of the peace, with power to decide summarily civil actions between traders or between traders and Indians involving not more than ten pounds sterling. Appeals to the superintendent or his deputy were allowed.

Articles twenty-three to forty related to trade. Under certain restrictions, trade was to be free and open to all of His Majesty's subjects, provided the 
rights of the Hudson Bay Company were respected. All colonial laws on the subject were declared repealed. Traders were to be licensed by the governor and council of the colony from which they intended to trade, and the license fee was to be not more than two shillings. They were to declare at what post or with what tribe they proposed to trade, and this was inserted in their licenses, which were renewed annually. No one could trade under a license, except the party named in it and his agents whose names were inserted on the margin. Licenses were registered in the secretary's office of the colony in which they were taken out, a fee of six pence being allowed for such entry. Traders were required to show their licenses to the commissary immediately on arriving at the post or in the tribe with which they intended to trade. Trade was to be conducted in accordance with a tariff of prices settled from time to time by a conference of the commissary, traders, and Indians. The sale of "rum or other spirituous liquors, swan shot, or rifled barrell'd guns" was forbidden. Standard weights and measures were kept at each town or trading post for use in settling disputes.

The estimated expense of this plan was $£ 20,000$ sterling per annum, which was to be raised by a duty on Indian trade, either collected as an export duty on skins and furs or else made payable by the traders at their places of trade, as should be found most practicable and least burdensome. ${ }^{1}$

After a few years' trial, the home government found the system too expensive to be self-supporting. Either

${ }^{1}$ Penn. Archives, Hazard series, IV, 182-189. 
they or the colonies would have to bear the burden, if it was continued. Consequently, the control of trade was given back to the colonies in 1768 , and the various deputies, commissaries, and interpreters in the pay of the crown were dismissed from service. Johnson and Stuart were, however, still retained as superintendents, with power to negotiate concerning boundaries of Indian tribes, to renew ancient compacts, reconcile differences and disputes, and hold interviews for various purposes. Each was to receive a salary of $£ 1,000$ per annum and £3,000 more for presents and other expenses, thus reducing the annual expenses from $£ 20,000$ to $£ 8,000 .{ }^{1}$

1 Penn. Archives, Hazard series, IV, 313-320; New York Col. Doc., VII, 981-984, VIII, 19-25, 55-58; Com. House Journals, Hs., XXXVIII, $308-310$. 


\section{CHAPTER VI}

Financial History

The term Financial History is used in this chapter to include both the monetary system, or Financial History in its narrow sense, and the revenue system, or what is technically known as Public Finance. Each of these admits of a two-fold treatment. There is, first, what may be called the statics of the subject. We may study the system as it existed without any special effort to discover the motive forces which produced it. This would satisfy the financier. It would let him know the character and amount of money in circulation at any particular time. It would inform him in regard to the sourees and amount of public revenue and describe the process of assessing and collecting taxes. But there remains a far more important phase of the subject, which we may call financial dynamics. The financial system is of interest to the student of history primarily because it helps to explain the constitutional development of the province-a development, by the way, which was almost identical with that taking place in Great Britain. The statement is often made that the liberties of Englishmen were purehased with money, that the House of Commons acquired its supremacy through the control of the public purse. This is equally true of the province of South Carolina. The 
thesis has already been advanced that the central fact in colonial history was the struggle between the popular and the prerogative elements in the government. An attempt has been made in previous chapters to indicate some of the various forms in which this struggle presented itself. But, just as in England, all other issues were subordinated to the money question.

It has been found impossible to separate entirely the statics and the dynamics of our subject, though some effort has been made in that direction. The rather detailed treatment which follows, of the disputes over the issue of paper money and of the efforts of the assembly to control money bills, has been regarded as necessary to a proper appreciation of the constitutional history of the province.

\section{A. Monetary System}

At various times during the colonial period, the following mediums of exchange were in use in South Carolina: produce, coin, legal tender bills of eredit, limited legal tender public orders, tax certificates, and certificates of indebtedness issued by the lower house.

When the first settlers came over in 1670, they brought a few small English coins with them, which for a time constituted the only money in circulation. As most of these were soon drawn away through trade with England, some medium of exchange had to be devised to carry on business. One remedy was to make country prodnce a legal tender. An act of July 23, 1687, provided that all debts might be paid in corn, peas, pork, beef, tobacco, and tar at certain fixed prices, 
unless the contract called for gold or silver or some particular commodity at a certain price. ${ }^{1}$

The deficiency of money was partially supplied by the various Spanish, Mexican, and Peruvian coins which were brought in by traders from the West Indies. Laws were enacted in 1683, 1691, 1695, 1697, 1700, and 1701, fixing their value in pounds and shillings. ${ }^{2}$ By the act of November 16, 1700, Mexican and Peruvian pieces of eight of thirteen pennyweight were rated at six shillings, half pieces being in proportion; double royals or reals at eighteen pence, singles and halves in proportion. All gold coins were rated at six shillings, six pence per pennyweight. The ratio between gold and silver was accordingly about 14.09 to 1 . In this act the common custom was followed of placing a high valuation on the coins in order to draw them away from the neighboring colonies. The attempts of the various colonies to thus outbid one another became such an evil that Queen Anne issued a proclamation, June 18, 1704, fixing a value upon foreign coins and forbidding any one to receive them at a higher rate. In 1707 the proclamation was embodied in an act of parliament and penalties were provided for its violation. ${ }^{3} \quad$ Paper currency was introduced in 1703 , and gold and silver soon ceased to be used, except in making foreign payments.

1 Statutes, II, 37 .

2 Ibid., v, 72-73, 94-95, 130, 163-164, I78.

3 Statutes at Large, 6 Anne, chap. 30. The act stated that pieces of eight of 17 pennyweight and 12 grains weight had a bullion value of 4 shillings 6 pence, that is 54 pence. They were not to be valued higher than 6 shillings that is 72 pence. The ratio between sterling and proclamation money thus becomes fixed at 54 to 72 , or 3 to 4 . $£ 100$ sterling was equiralent to $£ 1331 / 3$ proclamation money. 
It is practically impossible to estimate the amount of coin in the province at any time. Considerable sums seem to have come from the West Indies, but they were immediately exported. According to the report of a committee of the assembly, there was in the public treasury, on October 18, 1771, $559,520: 2: 0$ in gold and silver coin. This consisted of Spanish doubloons, Spanish milled dollars, Portuguese half joannes, and English guineas. ${ }^{1}$

To meet the expense of the expedition against St. Augustine, an act was passed, May 8, 1703, providing for the issue of $£ 6,000$ in bills of credit bearing interest at twelve per cent. This issue was to be redeemed within two years, $£ 2,000$ by direct tax, February, 1704, $£ 2,000$ more, February, 1705, and the remainder out of the funds arising from the duty act of May $6,1703 .^{2}$ Exchange being then at $1 \frac{1}{2}$ to 1 , this amount was equivalent to $£ 4,000$ sterling. $^{3}$

Instead of redeeming the bills according to law, the assembly permitted the taxes and duties levied for that purpose to be spent in fortifying Charleston and otherwise defending the province. The fiat money fever soon proved irresistible, and, as might have been expected, the currency was rapidly inflated, and promises

1 Com. House Journals, Ms., XXXVIII, 571.

2 Statutes, II, 200-212.

SThe following account of the currency up to 1740 is taken largely from "An Account of the Rise and Progress of the Paper Bills of Credit in South Carolina...., sent to the Board of Trade by LieutenantGovernor Bull, February 7,1740 . Public Records, Ms., XX, 214-247. Published in Statutes, IX, 766-780, also in Sound Currency, February 15, 1898, Vol. 5, No. 4. 
of repayment were recklessly disregarded. The following table will show the condition of affairs at the beginning of 1712 :

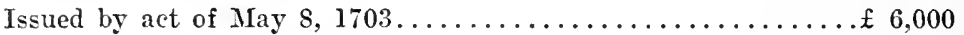

July $5,1707 \ldots \ldots \ldots \ldots \ldots \ldots \ldots \ldots \ldots, 8,000$

February 14, $1708 \ldots \ldots \ldots \ldots \ldots \ldots \ldots \ldots \ldots, 3,000$

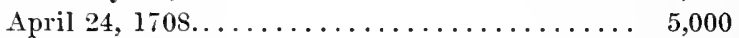

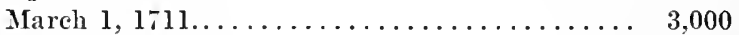

Tuscarora bills, November 10, $1711 \ldots \ldots \ldots \ldots \ldots \ldots \ldots \ldots \ldots, 0 \ldots 0$

Total issued $£ 29,000$

Redeemed by act of February 14, 1708.........£2,000

March $1,1711 \ldots \ldots \ldots \ldots \ldots \ldots \ldots 1,000$

Redeemed by various acts or destroyed..........6,000

Total redeemed $\ldots \ldots \ldots \ldots \ldots \ldots \ldots \ldots \ldots \ldots \ldots \ldots \ldots ., 9,000$

Total amount outstanding...............

The so-called Tuscarora bills consisted of $£ 4,000$, issued November 10, 1711, for the purpose of assisting North Carolina in the war with the Tuscarora Indians. They were to be redeemed by an additional duty on liquor and other merchandise. This left $£ 16,000$ outstanding, for the redemption of which no provision had been made.

The province now adopted a very plausible scheme, which was usually known in colonial times as a land bank. By the bank act of June 7,1712, 552,000 in bills of credit were issued, equivalent to $\$ 34,666: 13: 4$ sterling. $£ 16,000$ were to go toward replacing the old bills, $£ 4,000$ for contingencies, and the remaining $£ 32,000$ to be loaned at $12 \frac{1}{2}$ per cent. interest per annum for twelve

${ }^{1}$ Statutes, II, 206-212, 302-307, 320-323, 324-327, 352-354, 366, IX, 769 . 
years. The annual payments included interest and onetwelfth of the principal, so that by the end of the period the government would have recovered the original issue with a handsome profit, and the individual would be discharged from all further obligations. No individual could borrow less than $£ 100$ nor more than $£ 300$. Bonds, or mortgages on land and negroes, had to be given for double the amount borrowed, as security that the payments would be regularly made. In case any payment was delayed for ten days, execution would be issued against the delinquent for the amount due. The bills were made full legal tender for all debts, and a penalty was imposed for refusing to accept them. ${ }^{1}$

By the close of 1712 there were in circulation the $£ 52,000$ issued by this act and the $£ 4,000$ of Tuscarora bills. Depreciation rapidly set in. By 1715 the ratio of currency to sterling was two to one. To prosecute the war against the Yemassees, $£ 30,000$ more were issued in 1715 and $£ 20,000$ in $1716 .^{2}$ Provision was made for redeeming these bills, but the funds were usually diverted to other purposes. Numerous complaints having been made to the Lords Proprietors by London merchants who carried on trade with the province, instructions were sent out forbidding the governor to give his assent to any act for the further issue of bills of credit or for diverting the funds appropriated to redeem those already outstanding. ${ }^{3}$

No other emissions were made until after the over-

1 Statutes, IX, 759-765.

${ }^{2}$ Ibid., II, 627-633, 634-641, 662-676, IX, 770-771.

3 I'ublic Records, Us., VI, 69, VII, 32-33, 156-157. 
throw of the proprietary government. Under the revolutionary régime there was an issue of $£ 34,000$ of what were known as rice bills, because they were to be redeemed by a tax payable in rice, at the rate of thirty shillings per hundred. The rate of exchange had now risen to five to one. ${ }^{1}$

Royal government in South Carolina began with the arrival of Governor Francis Nicholson, May 23, 1721. ${ }^{2}$ The people received him with extravagant joy, and the assembly gave up some of the advantages which they had gained during the proprietary period. ${ }^{3}$ Aside from this there was no change worthy of mention in the constitution of the province. Governmental powers were transferred from the proprietors to the king, though the former still retained their territorial rights until 1729. The machinery of government in the province itself remained unchanged.

Nicholson was just the man to restore order after the excesses of the revolution. He had the benefit of a long experience in the colonial service, having presided for many years, either as governor or as lieutenant-governor over the provinces of New York, Maryland, Virginia, and Nova Scotia. Another advantage was the aid and sympathy which he received from his council. Reference has already been made to the fact that before 1760 the council was for the most part composed of the leading merchants and importers of Charleston. Repre-

${ }^{1}$ Statutes, IX, 773.

${ }^{2}$ Com. House Journals, IIs., V, 495.

s For example, the repeal of the law of 1707 vesting the sole power of electing the treasurer, powder receiver, and other public officials in the lower house. 
senting the creditor class, they found it to their interest to ally themselves with the crown officials in opposition to the planter element in the assembly. Fortunately for the interests of the crown, the first ten years of royal government were characterized by a continual struggle over the issue of paper money. This was settled in 1731, and the land question became the chief issue for several years. On this subject the interests of council and assembly were the same and the relations between them became more harmonious. The bitter conflict over the currency question, however, had made the members of the council very conservative. Throughout the whole colonial period, they were made to feel that it was only the strength of the crown which could save them from the fiat money schemes of the planters. Had the British government fully trusted these merchants and appointed them to positions of honor and trust in the province, they could have created a loyal element which would have afforded them good service in time of need. But this is exactly what they did not do. If a governor, or a chief justice, or a receiver of the quit rents was to be appointed, some second-rate officeseeker was sent out from England. This was done, too, in spite of the fact that there were scores of young men in Charleston, educated at Oxford and Cambridge, who were qualified to fill any office in the province.

After this digression, let us come back to our discussion of the monetary system. The opening of the period of royal government biings us again to the dynamics of the subject. The first steps were in the direction of greater inflation. An act of September 20, 1721, pro- 
vided for the reissue of $£ 15,000$ in rice bills, which should have been destroyed according to law. Provision was made for calling in all of the said bills, however, at the rate of $£ 4,000$ per annum. $^{1}$ At the beginning of 1723 there were in circulation $£ 8,000$ in bank bills of 1712 , and, it was estimated, $\mathfrak{7} 72,000$ of the other issues. A law of February 23 provided for the printing of $£ 120$,$000 \ldots £ 80,000$ to replace the old bills, and $£ \neq 0,000$ as a new issue, to be turned over to the public treasurer to meet the regular expenses of the government. Of this amount, the $£ 8,000$ in bank bills were to be redeemed by June 17, 1724, in accordance with the bank act; $£ 72,000$ by an extra annual tax of $£ 4,000$ per annum, as provided for in the law of 1721 ; and the $£ 40,000$ by a tax of $£ 5,000$ per annum, beginning in 1738 and ending in 1745. All were made a full legal tender and a penalty was affixed for refusing to receive them. ${ }^{2}$

This measure was not enacted without considerable opposition. On December 5, 1722, it was presented to the assembly by Benjamin Whitaker of the committee on ways and means, passed its first reading, and was sent to the upper house. ${ }^{3}$

On the following day, the merchants and traders of Charleston presented a long petition and memorial to the governor, council, and assembly. These documents were first read in the council and then sent down to the assembly. The petitioners humbly begged that the reasons offered in the memorial against the bill should

${ }^{1}$ Statutes, III, 149-157, 219.

2 Ibid., 188-193.

${ }^{3}$ Com. House Journals, Hs., VI, 97, 100, 103. 
be considered, and they asked to be given an opportunity to prove their allegations, in case any of them were doubted. The memorial took up the history of the currency from the first issue in 1703, considered the various acts increasing the amount, and called attention to the bad faith of the general assembly in repealing the several sinking fund acts before they could be put into operation. It further went on to speak of the depreciation of the currency at that time, and of the great injustice to the creditor class that would be caused by the emission of the amount proposed. This was signed by twenty-eight of the leading merchants of the province.'

The house resolved itself into a committee of the whole to consider the memorial. On December 8, they adopted a series of resolutions to the effect that, having gone through all the laws relating to the paper currency, they found that they had alwars been passed for the support of the public credit and the preservation of the province, and that they were not enacted with any design to injure or defraud any person whatever. They also affirmed "that the aforesaid memorial is false and scandalous, and destructive to the true interest of this province, and is a base reflection on the preceding Parliamentary proceedings and a high indignity to the present General Assembly.",

After the adoption of these resolutions, a motion was made and carried that the signers of the memorial should be taken into custody. The order was at once

1 Com. House Journals, Ms., VI, 99-104.

2 Ibid., 113. 
enforced by the messenger of the house. The imprisoned merchants petitioned the governor and council, asking to be heard on the subject matter of their memorial and of the bill. The council resolved that they should be allowed a hearing, according to the privileges of English subjects, but should then be returned into custody, so that the privileges of the commons might be preserved. The petition, together with this resolution, was sent down to the assembly. That body at once informed the council that their action was a "breach of the privileges of this House, for since they stand committed by this House, they cannot be released for any time but by the said power that committed them." At the same time a message was sent to the governor couched in the same general language, but containing an argument that is suggestive of future claims. "We are of opinion," ran the message, "that every petition against bills under consideration of the Assembly, especially such as concern money or supplies, ought to be first referred to and considered by this house where every inhabitant of this Province hath his representative, and in case the bill is passed with us, that then the petitioners may be heard before Your Excellency and His Majesty's Honorable Council." They went on to say that petitioning in a legal manner was the right of every English subject, but, at the same time, it was the undoubted right of the House of Commons to punish the petitioners for falsity, scandal, and insolence. ${ }^{1}$

${ }^{1}$ Com. House Journals, M/s., VI, 113-114, 117-120. 
On December 13 and 14, the several petitioners acknowledged their fault, confessed that their memorial was false and scandalous, and were dismissed from custody, after paying heavy fees to the clerk and messenger of the house. ${ }^{1}$

The opposition of the council was equally futile. In a message of December 13, they declared that there was already enough currency in circulation to carry on the trade of the province, but, considering the recent losses by flood and the consequent inability of the people to pay all the taxes for the year, they were willing to confer with the assembly in regard to printing a limited number of bills. ${ }^{2}$

The commons consented to this, and a grand conference of both houses was held on the 4 th, but no agreement could be reached. The council maintained that $£ 80,000$ should be issued to take the place of the old bills outstanding, and $£ 30,000$ additional for the support of the government. They suggested that no more should be issued than was absolutely necessary, for fear that the law might be disallowed in England. ${ }^{3}$

The assembly claimed that at least $£ 43,000$ additional was necessary, and that, considering the miseries of the people, a law should also be passed making produce a legal tender. In reply the council said that they would not consent to the issue of more than $£ 30,000$ extra, though the governor agreed to sign a legal tender produce bill. ${ }^{*}$

${ }^{1}$ Com. House Joumals, .Us., VI., 121-126.

I Ibid., 122.

'Council Journals, Ms., II, 137.

I Ibid., 13S-140. 
Another subject of dispute was in regard to the choice of commissioners for stamping the bills. The lower house thought that five commissioners would be necessary, but finally agreed to the governor's suggestion that three were sufficient. They selected Captain William Dry, Major 'Thomas Hepworth, and a Mr. Smith. The council struck out Smith's name and inserted that of Henry Howser. To the objections of the assembly, they replied that they had an undoubted right to nominate to office and proposed to exercise it. A deadlock was threatened, when the lower house, in their anxiety to secure an immediate passage of the bill, proposed that the governor should appoint the third commissioner. This was agreed to, and he appointed Howser. ${ }^{1}$

The council yielded on the question of the amount of currency to be issned, and, as already stated, the bill became a law on February 23. Being passed without a saving clanse, it went into force at once, but like other measures it had to be sent to England for His Majesty's approval. This transferred the controversy to London. The Charleston merchants laid the whole matter before the Board of Trade and petitioned for a repeal. ${ }^{2}$ They were more successful here, for, on August 27, 1723, the Lords Justices in council, acting on the recommendation of the Board of Trade, repealed both this law and that of September 20, 1721. Governor Nicholson was instructed to secure the immediate passage of an act to cancel the two issues. ${ }^{3}$

1 Council Journals, Ms., II, 221, 226-227, 236. This nane is sometimes spelled Houser.

2 Public Records, Ms., IX, 179-204.

3 Ibid., X, 125-127; Statutes, III, 193, IX, 775. 
In accordance with this instruction, "An Act for calling in and sinking the Paper Bills" was passed, February 15,1724 . The $£ 55,000$ which were issued under the two repealed laws were to be redeemed as follows: provincial customs duties, except those appropriated for the salaries of the clergy and for the building of the brick church in Charleston, were to be paid in these bills only, and, when received, they were to be burned every six months until all were destroyed. ${ }^{1}$

During the next six years, the planter element in the assembly directed all their efforts, first, to evade this sinking fund law, and secondly, to increase the paper currency by securing new issues.

Nicholson returned to England, Nay 17, 1725, and the government, according to instructions, devolved upon Arthur Middleton, the eldest member of the council. ${ }^{2}$ Middleton's task was a difficult one. Nicholson had put the new royal government into operation and directed its destinies for four years. He possessed the advantages of a wide experience in colonial administration and of the strong feeling of loyalty among the people which followed the downfall of proprietary rule. Although his administration was on the whole successful, he was involved in several serious disputes with the assembly. It might have been foreseen, then, that Middleton would inevitably fail, since he had neither the prestige of a royal commission nor the advantage of such a feeling of loyalty among the people. Though embarrassed by his record in favor of the people's rights

'Statutes, III, 219-221.

${ }^{2}$ Council Journals, Mis., III, 1.

16 
during the revolution of 1719 , he now set himself upon a high pedestal as guardian of "His Majesty's Royal Prerogative,"1 regarding it as his duty to uphold the rights and privileges of the crown, to resist obstinately all encroachments, and to make no compromises. The commons house, on the other hand, remembering his previous career and believing that as a native of the colony he would naturally side with them, thought this a capital opportunity to make substantial gains and to carry out their long cherished desire of further increasing the amount of paper money in circulation.

The assembly adjourned from May 15 to May 26. Messrs. John Lloyd, William Rhett, and Samuel Eveleigh, were selected as a committee to draw up during the recess a proper scheme concerning the best method for regulating the currency of the province. The plan, entitled, "A scheme for preserving the present paper currency of $£ 100,585^{2}$ and to add the sum of $£ 40,000$ to make the whole equivalent to $£ 20,000$ sterling, which sum there is an absolute necessity should be issued to support and carry on the trade of the province," was introduced on the first day of the new session, and a bill was ordered to be brought in in accordance therewith. The whole amount was to be loaned on landed security at ten per cent. interest. ${ }^{3}$ This scheme was practically

1 This expression occurred in nearly every message which he sent to the assembly.

2 This is apparently a low estimate. $\{120,000$ had been issued under the act of February 23, 1723. It is by no means likely that as much as $\mathfrak{2} 20,000$ had been redeemed under the sinking fund act of February 15, 1724. Indeed, only $\mathfrak{£} 13,500$ had been redeemed by 1730 . Statutes, IX, Tis.

${ }^{3}$ Com. House Journals, IIs., VII, 209-211. 
the same as that embodied in the bank act of 1712 . The plan was sent up to the council, together with a message asking them to concur in passing such a bill with a clause suspending its operation until approved by the home govermment. President Middleton, in reply, called attention to a petition recently sent to the king for permission to establish a land bank, and said that the passage of such a law without leave first being obtained would be to forestall His Majesty's judgment. In conclusion he declared that it was beyond his power to assent to such an act and cited the twenty-ninth article of Governor Nicholson's instructions, which provided that the eldest councilor should administer the govermment in the absence of the governor and lieutenant-governor, but should forbear to pass any acts, except such as were immediately necessary for the peace and welfare of the province, without a particular order from the king. The house seems to have been satisfied with this explanation and they asked the council to concur with them in laving their scheme before the king in order to secure his permission to put it into operation. The council rejected the scheme, giving as their reason the fact that a petition had already been sent to His Majesty to continue the present currency, which they regarded as sufficient for the needs of the province. Nothing more was done in regard to the matter during this session, which closed on June $1 .^{1}$

The operation of the sinking fund act had by this time begun to prove very burdensome to the debtor

${ }^{1}$ Com. House Journals, Ms., VII, 215-218, 232, 239-240. 
class, which for the most part inhabited the country parishes. The members of the assembly strove quite as hard to prevent its enforcement as they did to secure the issue of new bills of credit. 'Their first successful attempt to evade the law was made in 1726. Early in January, Fort King George on the Altamaha river was destroyed by fire and the independent company stationed there was left in an exposed and defenseless condition. The assembly was called together by special proclamation to take steps for sheltering and provisioning the garrison until help could be received from Great Britain. These troops were regulars, and it was naturally to be expected that the home government would take care of them as soon as they could learn of their sad plight. The assembly refused to make an appropriation even for temporary relief for fear the British government would not repay them. There was then in the province a considerable sum of money derived from fines and forfeitures, and they suggested that it should be used. Middleton showed that this was impossible, since a settlement had not ret been made between the crown and the proprietors. The next suggestion was that the commanding officer at the fort should draw bills on the proper person in Great Britain for so much money as would be necessary. Middleton disposed of this plan by saying that no one in the province would adrance mones on such bills. ${ }^{1}$ The third derice of the assembly was to make use of the paper money lring in the treasurer's hands waiting to be burned, as provided in the sinking fund act. The

${ }^{1}$ Con. House Joumals, Is., VII, 322-325, 325-326, 328-329. 
president agreed to this, on condition that both houses should join in a resolution to supply the deficiency in the way ordinarily taken for redeeming bills. The assembly then offered to appropriate two thousand pounds and to provide for replacing the amount, to be burned whenever the king repaid the province. The president agreed, an ordinance to this effect was hurriedly passed, and the assembly was prorogued on February 4 to the third Tuesday in March. ${ }^{1}$

The controversy next took the form of an attempt to increase the amount of money in circulation. On December 12 the lower house passed on its first reading, "A Bill for stamping the sum of $£ 86,100$ in bills of credit and for issuing the same to the inhabitants of this Province on good security," with a saving clause suspending its enforcement until the king's approbation could be secured. It was rejected by the council on the ground that it would be better to secure His Majesty's consent at the outset instead of passing the measure with a saving clause. The assembly expressed surprise that they should reject the bill without giving their house an opportunity in conference to explain it.

The dispute was renewed at the first meeting after the holidays, and a message was sent up to the president desiring that a joint committee from the two houses should consider the establishment of a sufficient currency. At the same time they resolved not to proceed on any business until an answer to this message was received, and notified the president of their action. Middleton replied that the council, and not himself had

${ }^{1}$ Com. House Journals, Ifs., VII, 330-335. 
rejected the bill, and that the assembly should send their messages to them. Accordingly, a similar message was sent to the council.

Their response was that they were always ready to appoint conference committees to secure harmony between the houses, but that they were forbidden by His Majesty's instructions to pass any law altering the currency without His Majesty's leave first being obtained. They went on to say that in their opinion the present currency was amply sufficient for the needs of the province. The assembly stated in reply that it was very unparliamentary for the council to appoint a conference committee, and yet declare beforehand that they would not agree to any compromise. Several messages passed on the subject, when it was dropped for a time and the tax bill for the year was taken under consideration. This measure became a law, March 11, 1727, and the assembly was prorogued to the second Tuesday in October. ${ }^{1}$

The session had barely closed when an agitation was begun in the country parishes, which developed into something little short of open rebellion. ${ }^{2}$ Riotous and tumultuous meetings were held, an association was formed, and a representation setting forth the grievances of the people was drawn up to be presented to the president and council. Complaint was made that the people were compelled to go down to Charleston for trial be-

1 Com. House Journals, Hs., VII, 394, 400-401, 411-415, 494, 526529 ; Statutes, III, 273.

2 The following account is taken mostly from "A Representation of the Council of South Carolina to the King's Most Excellent Majesty." Public Records, Hs., XIII, 271-335. 
fore base and unjust judges and were made a sacrifice to griping lawyers and extortionate officials, to whom they had to pay three or four times their just due, all for want of a law making country produce a legal tender or a law providing a sufficient quantity of paper bills for the trade of the province. They went on to say that base designing men hoarded the bills and that merchants kept them for buying foreign produce. The farmers were compelled to get money to pay their debts and their taxes, and hence were often forced to sell their estates for a quarter of their real value. Their troubles were further augmented by the gradual reduction of the currency through the operation of the law of 1724 . The address begged for a redress of grievances, and closed with a threat that the people would take matters into their own hands if the legislature refused to act.'

Riotous meetings continued to be held, and the president and council issued a proclamation for the mobs to disperse. Their leader, Thomas Smith, member of the assembly from St. James's, Santee, was committed to prison by Alexander Skene, a councilor. This served only to increase the tumult. Middleton reasoned with the mob and agreed to release Smith, provided they would disperse and burn their remonstrances. They consented to this arrangement, but soon repented of it and sent two of their leaders, William Waities and John Jones, to deliver the representation. The council refused to receive it. A few days later, two hundred men, led by Smith, Jones, Waities, and others, marched to town on horseback and rode up

${ }^{1}$ Public Records, Ms., XII, 211-214. 
to the council chamber fully armed, where two of their number presented the representation to President Middleton. Then they quietly departed from the town, but continued their meetings. Early in July, a general meeting was resolved upon at a place called Dry Savannah, about twenty-two miles from Charleston. The president issued a warrant against several of the leaders and a proclamation forbidding the meeting. ${ }^{1}$

Landgrave Thomas Smith, father of the Thomas Smith who was recently arrested, ${ }^{2}$ was at this time a member of the council, fifth in rank, though he had not attended their meetings since the latter part of Nicholson's administration. He joined the ranks of the discontented and made plans to have himself elected president. In June he wrote some letters to Captain John Croft of Charleston, in which he hinted that the purpose of the meeting at Dry Savannah was to collect a body of -men to march to Charleston and overthrow the government of Middleton and his "sham councilors." On discovering these letters, Middleton had Smith arrested for high treason and ordered the militia of the province to meet in Charleston. The meeting at Dry Savannah was broken up, but the disturbances by no means ceased. Advertisements were posted inviting all to join the association. The Goose Creek militia company, commanded by Captain William Dry, took the lead in the

1 Public Records, Ms., XIII, 292-294.

2 These two men are sometimes confounded with each other. The landgrave was an old man, and, as stated, was a member of the council. The scn had been a member of the assembly from St. James's Santee since April 25, 1726. Ibid., 220; Com. House Journals, Ms., VII, 336. 
commotions, and an effort made by the president to discharge them from service was treated with contempt. They planned to seize the Honorable Alexander Skene of the council, by way of reprisal for the imprisonment of the two Smiths. Petitions and representations were sent to the president and council and many demands were made that the assembly should be called to meet at once. The merchants and traders of Charleston, fearing the effects of a civil war, prevailed upon Middleton to call an assembly as the best means of quieting the people and inducing them to return to their homes. ${ }^{1}$

They met on August 1. The following resolutions adopted at the beginning of the session showed that they were not to be trifled with:

"Resolved, That it is the undoubted Right of His Majesty's Freeborn Subjects within this Province to represent their grievances to the Governor, Council, and Assembly for the time being jointly or separately and to petition to have them redressed. Resolved, That whoever asserts the Contrary is a betrayer of the Rights and Liberties of the people. Resolved, That all commitments and prosecutions for such petitioning are illegal. Resolved, That by the Election Act now in force the Assemblies of this Province ought to sit once in six months. Resolved, That this present assembly was prorogued from the 11th day of March last to the 2nd Tuesday in October which is seven months, notwithstanding the Election Act aforementioned. Resolved, That this house never proposed to the Council any bills that were disadvantageous to the Publick or contrary to His Majesty's Royal Orders and Instructions and that all insinuations to the Con-

1 Public Records, Mls., XIII, 294-301. 
trary are highly reflecting upon the Honor and Dignity of this House." 1

The next matter that came up was, "A memorial of Landgrave Thomas Smith setting forth his great hardship in being detained in prison, notwithstanding he had petitioned for the benefit of the Habeas Corpus Act, and praying relief.' 'This document set forth the manner of his arrest and complained that the military power had been called in to assist the civil. Reference was here made to the fact that some men from Captain Anson's man-of-war had given aid to the town constables. Complaint was also made against the chief justice for refusing to issue a writ of habeas corpus. The memorial concluded with a prayer that the assembly would declare him within the benefits of the habeas corpus act and that his counsel learned in the law might be heard before the bar of the house. ${ }^{2}$

The assembly roted him a hearing at ten o'clock on the following morning, and then took up a series of petitions from the inhabitants of the parishes of St. James's Santee, Christ Church, St. Thomas's and St. Dennis's, St. Paul's and St. Bartholomew's, and St. John's. The substance of all was the same, to increase the currency, to set a rate on foreign coins different from that established by the statute of the 6th of Anne, and to pass other laws to screen them from their creditors. $^{3}$ The house notified the bearers of the petitions

1 Com. House Journals, Ms., VII, 554. The last clause had reference to a proclamation issued by the president on June 19.

2Ibid., 557; Public Records, Ms., XIII, 28-30, 303.

3 Public Records, Hs., XIII, 19-27, 31-32. 
that they would consider them at once, and then gave them attested copies of the resolutions adopted the preceding day in order that they might be scattered throughout the province. ${ }^{1}$

The council were very angry that a member of their board should apply to the lower house for a redress of grievances. President Middleton at once sent down a message saying that he had heard of Smith's memorial and the action of the house thereon, and that "His Majesty's Royal Prerogative" was highly concerned. He demanded that the house should send him at once attested copies of the said memorial and of their resolutions concerning the same, and also a copy of their resolutions of the previous day.

The assembly made no haste to reply, and Middleton sent another message the same afternoon requiring and commanding them to comply with his request immediately. They now answered that they would have sent up the copies at once, had he desired, instead of demanding, requiring, and commanding them. However, they said that they had ordered their clerk to deliver copies to any person he might select to receive them. ${ }^{3}$

On the next day, August 4, the assembly directed the clerk of the crown to produce what papers he had in regard to Landgrave Smith's commitment, and ordered Chief Justice Richard Allein to attend the house. Middleton, hearing of this, sent a message requiring the immediate attendance of the house in the council chamber. He made them a speech, saying that their

1 Com. House Journals, Ms., VII, 558.

2 Ibid., 561.

s Ibid., 562. 
interference in the Smith case was of much concern to His Majesty's prerogative, that high treason was a crime that could be considered only in the king's courts, and that they must desist from further proceedings, as he would "not suffer His Majesty's Royal Prerogative nor his Courts to be trampled upon.", The assembly retired to their own chamber and voted to proceed with the Smith affair. His attorney, Nicholas Trott, was admitted to the bar of the house, where he proceeded to show that Smith was rightfully entitled to a writ of habeas corpus. The doors were thrown open, and crowds of people awaited in and around the house to hear the result of the examination. The president and council, being very much incensed at such conduct, roted unanimously that the assembly ought to be dissolved at once; but, because of the prospect of war with the Indians and Spanish, they decided instead to prorogue them to September 2. This was done, however, before the assembly could adopt any resolutions on the Smith case. ${ }^{1}$

The ravages of the Yemassees on the southern frontier made it necessary to call them together on August 23. Indian affairs at once came up for consideration. A committee of the assembly reported that three hundred men should be raised and equipped, and a fort built at Beaufort and another among the Creeks. To meet these expenses, they proposed their old expedient, namely, to issue as a loan the paper bills in the treasurer's hands waiting to be burned, and to appropriate

${ }^{1}$ Com. House Journals, Ms., VII, 562-565; Public Records, Mfs., XIII, 305-306. 
the duties arising from the sinking fund act for war purposes. A majority of the council was prevailed upon to agree to this, on condition that the money should as soon as possible be repaid by way of a tax and burned. ${ }^{1}$

Having partly provided for the settlement of Indian troubles, the house came back to their favorite subject, and, on August 30, appointed William Rhett, John Lloyd, and George Smith a committee to consider the state of the currency. ${ }^{2}$ Their report, made on the following day, declared that the amount of currency in circulation was entirely inadequate for the needs of the province, and suggested as a remedy, "That a bill be brought in to promote and Encourage the Currency of Silver and Gold in this Province by affixing the value thereof in the present paper currency to a proportion as near and equal as may be either to Sterling or Proclamation money." All gold and silver coins of England, Spain, and other countries were to circulate in the province at a fixed valuation. The report went on to state that thousands of ounces of gold and silver were annually imported to purchase rice, and that such a law would cause it to remain and increase the volume of money in circulation. The report was agreed to, and the committee was ordered to bring in a bill. ${ }^{3}$

The bill was presented, passed the house September 1 , and was sent to the council. The final clause pro-

${ }^{1}$ Com. House Journals, Ms., VII, 5־1-572, 575; Public Records, Is., XIII, 307.

${ }^{2}$ Com. House Journals, His., VII, 584.

3 Ibid., 589-591. 
vided for the enforcement of the act, notwithstanding any law to the contrary, thus directly contravening the proclamation statute of the 6th of Anne. ' A message from the council reminded the house that they had been called to consider Indian affairs, and recommended that they finish those matters before attending to other business. The retort of the commons was that they had never heard that assemblies were restricted as to what they were to do, and that they regarded the currency act as of the utmost importance."

The illness of the president and the lack of a quorum of the council caused little business to be done from the $2 d$ to the 16th of September. On the day last mentioned a message from the council stated that they could not agree to the bill, since it was contrary to the statute of the 6th of Anne and the instruction to the governor to observe the same. Four days later, however, they yielded so far as to agree to pass the measure, provided it was not made retroactive and contained a clause suspending its execution until the king's approbation could be secured. Otherwise, they declared that they neither could nor would pass it. ${ }^{3}$ This message, like many others, was signed jointly by President Middleton and second councilor, Ralph Izard. The assembly regarded it as very unparliamentary for the president to join with the council in saying that he neither could nor would pass a bill, "before ever such a bill hath been tendered for his Assent or come properly before him." 308 .

${ }^{1}$ Com. House Joumals, Ms., VII, 592-593; Public Records, Ms., XIII,

2 Com. House Journals, Hs., VII, 598-599.

${ }^{3}$ Ibid., 610, 613. This was known as a saving clause. 
The opening paragraph of their reply will serve to give some idea of their indignant frame of mind:

" 'Tis with the greatest surprise and Concern that we have read your message of Yesterday afternoon-sent down with the bill for promoting the Currency of Gold and Silver. If we must submit to what you would thereby arbitrarily impose upon us, Freedom of debate and all our essential and undoubted Privileges are destroyed and taken away, a tyranny introduced, as yet (we thank God) unknown to our Constitution, and His Majesty's good and Lawful Subjects of this Province reduced to the Condition of Vassals and Slaves, a consideration on which we cannot reflect without the utmost abhorrence and detestation."

Middleton defended himself by citing precedents from Nicholson's administration to show that he occasionally refused his assent to bills before they came before him in their final form. For example, in 1724, he informed the house that he would not pass a legal tender produce bill without a saving clause. ${ }^{2}$

Not discouraged by their failure, the commons at once passed on its first reading "A bill to settle and ascertain the value of the paper bills of Credit in this Province and to promote the Currency of Gold and Silver," which was about the same as the preceding bill with a slightly different title. It was promptly rejected by the council. ${ }^{3}$ Then followed the usual number of messages filled with references to the royal prerogative and to the rights and liberties of the subject.

1 Com. House Journals, Ms., VII, 614.

2 Ibid., 617.

3Ibid, 617, 624; Public Records, Ms., XIII, 311-312. 
The session was closed, September 30, with the ratification of two acts in regard to Indian affairs, one for carrying on several expeditions against the Indians and the other for appointing an Indian commissioner. ${ }^{1}$ Though many assemblies were called, there was no further legislation until the arrival of Governor Johnson four years later.

Prorogued from September 30 to the second Thursday in November, the life of the assembly was closed before the latter date by the demise of George I. A new assembly was summoned for December 18, but, as the writs were not duly published and executed as provided by the election act, another was called to meet, January 31, 1728.

This assembly, the third of the royal period, met on the day appointed and elected as their speaker Captain William Dry, who, as captain of the Goose Creek militia, had taken such a prominent part in the disturbances of the previous summer. ${ }^{3}$

While the houses of assembly were disputing over the currency question, the Indians were murdering and pillaging on the frontier. Many settlers left the province in sheer despair. On February 17, the lower house proposed their old expedient of using the sinking fund to meet the expenses of an Indian expedition. They doubtless expected that the council would again

1 Statutes, III, 273. Titles only.

${ }_{2}$ Public Records, Ms., XIII, 313; Council Journals, Ms., IV, 113.

s Council Journals, Ms., IV, 117, 119. The original assembly journals from 1728 to 1734 have been lost, but copies were recently obtained from the British Public Record Office and bound in extra volumes of the Public Records. These are eited as Public Records, Extra, Ms. 
be forced to consent, as they had been during the previous session. This was not the case, however, for the bill was sent down as rejected, together with a long message stating the reasons for said rejection and criticising the assembly for their attempts to break through the sinking fund act. The message went on to tell of the exposed condition of the frontiers, and to urge that a tax be raised at once to build forts and provision the troops. ${ }^{1}$

Meanwhile the currency bill had not been neglected. On February 15, Mr. Rhett, from the committee on the state of the currency, made a report. He said that of the $£ 120,000$ issued in $1723, £ 13,645$ had been called in and burned by 1726. Since then $£ 33,645$ had been paid in to the treasurer to be destroyed. Of this amount $£ 20,000$ had been appropriated by the previous assembly for expeditions against the Indians, and the report intimated that the remainder would be disposed of in the same way. Accordingly, there were now, or soon would be, $£ 106,355$ in circulation, which the committee regarded as insufficient to carry on the trade of the province. They proposed that these bills should be reprinted on parchment and made a full legal tender, and that a law should be passed to enforce and make effectual the proclamation statute of the 6th of Anne. By this they meant that they would settle a definite rate of exchange between proclamation money and currency, and all debts were to be payable in either at the legal ratio." In accordance with this report, "A Bill

${ }^{1}$ Public Records, Extra, Ms., I, Part I, 375, 385, 393-395.

2 Ibid., 379-381. 
to Settle and Ascertain the Discount on Paper Bills of Credit" was drawn up, passed through the house, and sent to the council. The council's reply, made on March 1, covers twelve elosely written pages of the usual ledger size. They went into a history of the troubles in regard to the currency and called attention to the similarity of this bill to the two rejected in the previous sessions. If the act simply confirmed the statute of the 6th of Anne it would be useless; if, on the other hand, it contradicted that statute, what was that "but to pass a Carolina law with a non obstante to a British Act of Parliament and of purpose for His Majesty's Plantations?" They closed with the declaration that they would never consent to such an act without a saving clause.

Considering this message in connection with a report from the council to the king, we are able to discover the cause of the distress in the province. By purchasing negro slaves beyond their ability to pay, the planters had become deeply indebted to the merchants of Charleston and London. The gradual reduction of the currency, as provided for in the sinking fund act of 1724 , made it more and more difficult to meet their obligations. In spite of all their efforts to hinder the enforcement of the law, the assembly realized that the bills would gradually be redeemed and the ratio between currency and proclamation money lowered. So they adopted the expedient of passing an act to allow debtors the option of paying their debts either in currency or proclamation money at a fixed ${ }^{1}$ Public Records, Extra, IIs., I, Part I, 407-419. 
rate of exchange. This gave an advantage to the debtor, whether the ratio went up or down, or, as it was expressed in the council's message, "After' a Debtor has kept his Creditor as long out of his Debt as he thinks fit, he shall discharge it whenever he pleases by paying Twenty Pounds Proclamation Money for One Hundred Pounds this currency and let the Bills be at what Discount they will the Trader shall have no more, though the bond be to pay Current Bills and the Exchange shall fall twenty per cent." 1

A message from the assembly on March 5 contained a long and elaborate argument to prove that the proposed act was in no way contrary to the statute of the 6 th of Anne, and closed by urging its immediate enactment without a saving clause. ${ }^{2}$ Along with this message was sent up the currency bill, which had been read and passed a second time in the assembly. It was promptly rejected by the council. To a request from the assembly that they would let them know in what manner they would join in settling the currency, the council again declared their intention not to pass any currency act without a saving clause. ${ }^{3}$

President Middleton reminded the assembly on the 9th that they had been sitting for five weeks and had as yet taken no steps toward providing for the support of the government. He recommended that they should at once consider the estimates and the annual tax bill. Their reply was that the comcil, by rejecting the cur-

1 Public Records, Extra, Ms., I, Part 1, 418; Public Records, Is., XIII, 315-316.

${ }^{2}$ Public Records, Extra, Ms., I, Part I, 423-432.

s Ibid., 433, 437, 441, 442, 445. 
rency bill, had taken from them the means of raising the necessary supplies. In conclusion, they said, "We humbly propose that a Loan be made of the money Designed for the Creek Expedition to furnish our immediate necessities, since it is agreed that it is not easy to prosecute that undertaking." This money had been appropriated out of the sinking fund. The idea of the assembly was to delar the tax bill until the executive was compelled to use it for current expenses. Middleton declared that he could see no connection between the currency act and a tax bill, and, as for their proposition in regard to a loan of the money voted for the Creek expedition, it was too preposterous to be considered. Not to be thwarted in their efforts to get the currency into circulation, the assembly now demanded that the expedition against the Creeks should be undertaken at once. The president called attention to their recent statement that there was no further occasion for it, and declared that he would not begin war with the Indians if it could be avoided.

The subsequent conduct of the assembly is well described in the following account taken from the report of the council to the crown, already referred to:

"At length they made a show as if they intended to raise a Tax, and on the 23d of MIarch sent up a Tax Bill once read, which was read and sent down to them the 4th of April following. But instead of giring it a second reading, they sat from the Fourth of April until the Tenth in order to weary out your Majesty's Council (after they had sat about nine weeks already) in appointing Committees and Reading of

1 Public Records, Extra, Hs.. I, Part I, 449-450, 453-454, 469-470. 
Bills about Turnpikes, Weights and Measures, Highways, Grievances, Revising Joumals, and every Trifle they could think of, and then on the 12th of April they sent up to your Majesty's Council another Currency Bill entitled, 'A Bill to promote and encourage the Importation of Gold,' of the same stamp with their Silver Bill, to force creditors to take it at the price set upon it by their Act and the prices made perpetual."'1

The assembly adjourned from April 13 to April 30. After a quorum was secured their first business was to send up a message inquiring about the currency bill. The council in turn asked about the tax bill, which was lying before the assembly. Some time was spent in dispute, one house insisting upon a consideration of the currency act and the other of the tax act. On the refusal of the lower house to consent to a saving clause, the currency bill was again defeated.2

The assembly now turned their attention again to the case of Landgrave Smith. Smith sent in another memorial recapitulating his former complaints against Chief Justice Allein for refusing to grant the writ of habeas corpus, and further complaining that he kept him under $£ 10,000$ bail for nearly a year and would neither bring him to trial nor discharge him. The memorial was referred to a committee, which reported that these proceedings were arbitrary, illegal, and unprecedented, and recommended the assembly to consider the matter until justice was secured. The report was taken under consideration, and the assembly re-

1 Public Rccords, Ms., XIII, 320-321.

${ }^{2}$ Public Records, Extra, Ms., I, Part I, 496, 500-501, 509-510. 
solved that Judge Allein should be served with a copy of the said report and ordered to attend at the bar of the house at ten o'clock the following morning with a written answer to Smith's complaint. ${ }^{1}$ Allein refused to appear, and sent a letter stating that he could not do so without derogating from the power and authority entrusted to him by the royal commission. ${ }^{2}$ The assembly at once resolved that this answer was an affront to the honor of their house and a high contempt of its dignity, and ordered that the judge should be taken into the custody of their messenger. The messenger hastened to execute the order and found Allein in the council chamber. He was proceeding to take the chief justice in charge, when he was seized by President Middleton and turned out of the room without much ceremony. On receiving news of this, the assembly resolved that the conduct of the president was arbitrary, umprecedented, an infringement on the liberties and privileges of the house, and a high affront to their honor. A message in accordance with this resolution was sent up to the president. ${ }^{3} \quad$ Middleton now decided to appeal to the people, the assembly was dissolved, and a new election was ordered. ${ }^{+}$The appeal was in vain. Nearly all of the old members were returned, and Captain Dry was again chosen speaker. When Dry was presented to the president for his approbation, he demanded a conservation of the riglits and privileges

1 Publie Rccords, Extra, Hs., I, Part I, 519-520.

2 lbid., 522-523; Public Records, Ms., XIII, 327.

3 Public Records, Extra, Ms., I, Part I, 521-523.

- Council Journals, Hs., IV, 203-204. This assembly met July 9. 
of the assembly instead of desiring it. ${ }^{1} \quad$ Middleton replied that he did not intend to invade their privileges and desired that they would not invade his, and then went on to urge them to lay aside all animosities and provide for the support of the government. The assembly professed a willingness to do this, but, instead of proceeding on the tax bill, appointed a committee on the currency and requested the council to appoint a similar committee for a conference. This they refused to do. ${ }^{2}$

All of a sudden the house began to manifest unusual zeal in considering Indian affairs. On the 17 th, a message was sent up asking for a conference committee to consider the framing of an Indian trade act. The council replied very curtly that the principal business was to raise money for the support of the government and that that matter must be dispatched before any other affair whatsoever. ${ }^{3}$

In answer to this, there was sent up the next day a new currency bill entitled, "A Bill to Establish a sufficient Fund of Gold and Silver and also to call in and sink the Paper Currency of this Province." It was rejected by the council on its first reading. On receiving a message to that effect, the assembly desired leave to adjourn until September, saying that, on account of the excessive heat and the illness of members, they could not keep together a quorum for business. Middleton refused the request and said that a tax bill must first be passed. The assembly then adjourned to the follow-

1 Council Journals, IIs., IV, 205-206; Public Records, Js., XIII, 330.

2 Council Journals, Ms., IV, 206-207, 209.

3 lbid., 211. 
ing Monday, July 22, when only the speaker and two members appeared. They continued to meet until the 25th and then absented themselves also. The council resolved that such conduct was "a high Indignity and Contempt offered to His Majesty's Royal authority, greatly prejudicial to the Interest of this His Province, and contrary to His Majesty's Royal Instructions." A proclamation was issued on the 27 th dissolving the house. ${ }^{1}$

Writs were issued for a new assembly to meet September 17. On the appointed day only a few members were present, and Middleton prorogued them from time to time until the 20th of November. The council then met, and, after waiting for three days, decided that the members of the lower house were purposely absenting themselves, and advised the president to dissolve their body. This was accordingly done on the $23 \mathrm{~d}$ of November. ${ }^{2}$

Another assembly was now summoned to meet January 15, 1729. On account of the extremely cold weather, a quorum was not secured until the 17th. The same members were returned and the same speaker was chosen. He again demanded a conservation of the rights and privileges of the assembly. ${ }^{3}$ President Middleton urged the necessity of the immediate passage of a tax bill, stating that the salaries of all officers of the government were in arrears from one and a half to two years. "A Bill to encourage the importation

${ }^{1}$ Council Journals, 11 s., IV, 213, 215-216, 219, 221-222.

2 Ibid., 224-230.

3 Ibid., 231-234; Public Records, Extra, Ms., I, Part II, 559-561, 566. 
of Silver and Gold by making both current in all payments" passed the assembly on the 25th. It was the same as the previous currency bills, being the seventh of its kind. The council again rejected it and declared that they would enter upon no business whatever until supplies for the support of the government were granted. To this the assembly replied that they would not pass a tax bill until some way could be found for settling the currency, and they asked for a conference committee on the subject. The council ignored the request and adhered to their resolution not to proceed on any other business until the tax bill was passed. ${ }^{1}$

A committee was appointed, on February 1, to consider the general state of the province. They reported on the 4th, that they found the province "in a very distressed and calamitous condition occasioned by the great losses which the Inhabitants in general have sustained by the late dreadful hurricane and storms, by the great mortality among them and their slaves, by the large and growing Debts of the Province, the scarcity of money, and the decay of public credit, all which unless timely prevented by the care of the Legislature must produce fatal consequences to the Province." The report went on to suggest that a bill should be passed fixing the rate between coin and currency, and that the current expenses of the government should be defrayed out of the funds in the treasurer's hands waiting to be burned. The report was adopted and there was passed on its first reading "A Bill to make Gold a tender in all payments and to make Silver Cur-

1 Public Records, Extra, Hs., I, Part II, 561-563, 572, 580-583. 
rent in all payments to and from the Publick." 'The council in reply said that, as it was very unparliamentary for the assembly to send up two bills of the same nature during one session, they did not think fit to give it a reading. In concluding, they reaffirmed their determination not to enter upon any business until supplies for the support of the govermment were granted.' Numerous other messages passed on the subject, and the bitterness between the houses increased.

The dissolution of the assembly was brought about in this way. A certain Henry Hargrave was deputy secretary of the province, as well as clerk of the council. He was ordered to appear before the bar of the lower house and answer certain questions in his capacity as deputy secretary. The council refused to allow him to attend. Being sent down shortly afterwards with a message, he was detained by the assembly and asked his reasons for not obeying their order. He pleaded in defense the council's refusal to grant permission. The speaker then asked him if Governor Nicholson's instructions were not recorded in the secretary's office, and he refused to answer. John Brown, messenger of the assembly, was now ordered to take Hargrave into custody. Middleton and the council refused to receive any messages or transact business until he was released. The lower house resolved that the refusal of the president to receive their messages and addresses was unparliamentary and an infringement on their privileges. $^{2}$ A proclamation was issued, on February 21 , to dissolve the assembly. ${ }^{3}$

1 Public Records, Extra, Ms., I, Part II, 586-593.

2 Ibid., 597-598, 601-602.

${ }^{3}$ Council Journals, Ms., IV, 257. 
Another assembly, the seventh of the royal period, was called to meet on August 6. The old leaders, William Dry, John Lloyd, Paul Jenys, William Waities, Benjamin Whitaker, and Thomas Smith were all returned. Conspicuous among the new members was Chief Justice Allein, the old antagonist of Landgrave Smith. As in the previous summer, most of the members refused to appear, and the assembly was prorogued from time to time until October 17, and was then dissolved. There was never a quorum present, except on October 15, when twenty-two members appeared before the council and took the state oaths. In order to prevent the organization of the assembly, all but nine of these refused to take the qualification oath in their own house and hence no business could be done. Exasperated by such conduct, President Middleton issued another proclamation of dissolution on the 17 th. $^{1}$

Writs were again issued for a new assembly to meet on December 2, but before that date they were prorogued to January 13, 1730. Most of the old members were re-elected, though for some reason Captain Dry's name was not among those returned from Goose Creek. Mr. John Lloyd of St. Thomas's and St. Dennis's was chosen speaker. In his speech to the president, he merely claimed, instead of demanding, the usual rights and privileges of the house. ${ }^{2}$ The history of this assembly was very similar to that of its immediate predecessors. Its existence was terminated by dissolution on April 29, and there is no evidence to show that an

1 Council Journals, Ms., IV, 257-266.

2 Ibid., 266-269. 
assembly ever met again until after the arrival of Governor Johnson in December, $1730 .^{1}$

During this long controversy in the province, the affairs of South Carolina were not being neglected in Fngland. Reference has already been made in the section on the land system to the parliamentary statute of 1729 providing for the surrender of the proprietary charter and the assumption by the crown of seveneighths of the property rights of the proprietors. South Carolina, which had been under a provisional government since 1721, now became in the fullest sense a royal province, and the king became its territorial lord as well as its governmental head.

The first business of the crown was to appoint a governor and give him definite instructions to settle the disturbances in the province. As early apparently as 1726, Robert Johnson, the last of the proprietary governors, was in England using all his efforts to displace Nicholson and to secure for himself a royal commission. $^{2} \quad$ He was finally successful, for the king gave notice of his appointment, November 22, 1729, and ordered the Board of Trade to draw up his commission and instructions. ${ }^{3}$ The commission was signed, January $1,1730,{ }^{4}$ though the instructions were not completed until the following June. The reason for this delay is to be found partly in the red-tape, characteristic of the English govelmmental system of that day, but principally in the difficult character of the problems

${ }^{1}$ Council Journals, . Is., IV, 276-279, 2980.

${ }^{2}$ Public Records, Ms., XII, 183-185.

3 Ibid., XIII, 245 .

'Council Journals, Ms., V, 1-7. 
that had to be solved. There were two leading questions at issue, the settlement of the quit rents and the settlement of the finances. The first has already been considered in connection with the land system. The governor was allowed to consent to the passage of an act remitting the arrears of rent, provided it required future payments to be made in proclamation money, required a registration of titles, and repealed the land law of 1696.

The other problem, that in regard to the finances, was more difficult of solution. As we have already seen, the province was reduced almost to a state of anarchy while the legislative houses were quarreling over the currency. Most of the provincial laws, being temporary in character, had expired; officials could not be paid, as no tax bills were passed; trade, agriculture. and all forms of business began to suffer. Neither the council nor the assembly would make the slightest concession, and it became evident that the home government would have to settle the matter. The lower house sent petitions and memorials to England begging for a suspension of the sinking fund act and for a further increase of the currency. A long representation of the council to His Majesty gave their side of the controversy. They also had a special agent in London, Mr. Stephen Godin, who was a zealous advocate of their views. ${ }^{2}$ Trade became so much affected by the unsettled condition of the province that the merchants

1 Public Records, JIs., XIII, 271-335. The account just given is taken largely from this representation and from the journals.

q llid., 350-372. 
of London trading to South Carolina finally decided to take a hand in the matter. On February 4, 1730, they petitioned the Board of Trade to instruct the newly appointed governor to assent to an act for emitting $£ 100$,000 in currency to retire the outstanding bills, and to allow a suspension of the sinking fund law for seven years and the use of the funds for the support of poor Protestant settlers. This was signed by twenty-one merchants. ${ }^{1}$

The following month, a paper, entitled "State of the Paper Currency in South Carolina and a proposal in relation to the same," was laid before the Board of Trade by Governor Johnson. He said that a paper currency was absolutely necessary, and that the only question was in regard to the amount. He suggested the issue of $£ 106,000$ to replace the old bills, thus favoring the views of the merchants rather than those of the planters, who thought that $£ 140,000$ at least were necessary. ${ }^{2}$

After considering carefully these various plans and arguments, the Board finally drew up Johnson's instructions in accordance with the proposition of the merchants. He was to consent to a suspension of the sinking fund act for seven years, and allow the funds to be used in laring out townships and purchasing supplies for poor Protestant settlers. Another article empowered him to consent to an act for establishing a new paper currency upon such a footing as would best answer the needs of the province, provided that the said act contained a saving clause. ${ }^{3}$

1 Public Records, Ms., XIV, 32-33.

${ }^{2}$ Ibid., 61-68.

${ }^{3}$ Ibid., 15i-159. 
The instructions contained one hundred and twentyfour articles altogether. With some slight changes due to circumstances, they were the same usually given to colonial governors. The members of the council were named in the first article. They were Thomas Broughton, Johnson's brother-in-law, who was later commissioned lieutenant-governor, Arthur Middleton, Ralph Izard, William Bull, Alexander Skene, Francis Yonge, James Kinlock, Robert Wright, John Fenwicke, Joseph Wragg, Thomas Waring, and John Hammerton. ${ }^{1}$

Johnson arrived in the province about the middle of December, 1730. On the 16th the council met, and his commission was ordered to be read publicly. Accordingly, the governor, council, and a large concourse of people repaired to Granville's bastion, where the commission was read and the cannons fired a salute. Going back to the council chamber, the governor and councilors took the oaths of office and proceeded to business. A proclamation was issued continuing all officers, civil and military, in their respective posts until further orders. $^{2}$

Johnson's first assembly met January 20, 1731. Many of the old members were returned, and John Lloyd was again chosen speaker. ${ }^{3}$ Governor Johnson, in his opening speech, told of the purchase of the province by the crown and predicted a bright future. He urged the members to forget all animosities and to provide for the public debts, now four years in arrears. ${ }^{*}$

Public Records, Ms., XIV, 147-214, 14i-14S.

2 Council Journals, Ms., V, 9.

${ }^{3}$ Public Records, Extra, Hs., I, Part II, 605.

I Ibid., 605-608. 
Both houses followed this advice. The quit rent act has already been considered, so far as it affected the land system. In addition, however, it suspended the sinking fund law of 1724 for seven years, and provided that the funds already in the treasury by virtue of that law should be appropriated toward paying the public debt, that $£ 5,000$ per annum for the next seven years should be used for aiding poor Protestant settlers, and the remainder for paying the residue of the public debt. $^{1}$

Another law was necessary to put this plan into operation. The last appropriation bill, passed in March, 1727 , provided for the expenses of the government up to September of that year. No taxes having been raised since then, the government was deeply in debt. As it was impossible to raise by direct tax more than enough for the current year, the following expedient was adopted. The debts, which had accrued from September, 1727 , to March, 1731, amounted to $£ 104,775: 1: 3 \frac{1}{\ddagger}$. A law was enacted authorizing the issue of public orders to this amount, bearing interest at five per cent. until paid off. These were to be redeemed in seven years, as follows: The $£ 40,000$ in the treasury waiting to be burned in accordance with the sinking fund act were appropriated to this purpose. The amount coming into the treasury by virtue of the said act was computed at $£ 13,500$ annually, of which $£ 8,500$ came from the duty on negroes and $£ 5,000$ from the duties on liquors and merchandise. The negro duties for seven years, amounting to $£ 59,500$, were to be used for redeeming orders, the duties on liquor and merchandise,

1 Statutes, III, 289-304. 
for subsisting poor Protestant settlers. It was estimated that the entire issue would be redeemed within seven years. ${ }^{1}$ How this could be done without an increase in the negro duties, is not clear. As a matter of fact they were not all redeemed until $17500^{2}$

The passage of this measure was delayed by a dispute over the allowance to President Middleton for his services as acting governor. He was summoned before a committee of the assembly, and asked if he had ever during his administration sent any memorial or representation to Great Britain relating to the public affairs of the province. He replied that he had not, and that he had never complained to the home government against any set of inhabitants in general or against any persons in particular. In spite of this humble explanation, he received little more than half the amount really due him. ${ }^{3}$ His case was a warning to public officials not to oppose the popular will. The efforts of Governor Johnson to have a permanent salary settled upon the governor, and the struggle of Chief Justice Wright to secure his allowance have been discussed in other connections. ${ }^{4}$

So far the planters had gained one point: they had secured the suspension of the sinking fund act. They failed, however, to obtain an increased issue of paper money. Only $£ 13,500$ had been canceled under the sinking fund act of 1724. Deducting this from the $£ 120,000$ issued in 1723 , there remained $£ 106,500$ in

1 Statutes, III, 334-341.

2 Com. House Journals, Mfs., XXV, 140.

3 Public Records, Extra, Ms., I, Part II, 699, 711, 791-792.

see Land System, Chapter II, Land Frauds; Government, Chapter I, The Exfcutive. 
circulation. ${ }^{1}$ A statute of August 20, 1731, provided for the issue of this amount in new bills to replace the old. If any surplus remained, it was to be turned over to the treasurer and used for public purposes. The law was without any saving clause and made no provision for the redemption and destruction of the bills. ${ }^{2}$ This sum of $\$ 106,500$, reprinted in 1748 when the bills had become torn and defaced, ${ }^{3}$ remained until the Revolution as the only paper money that was full legal tender in all payments. Another act to authorize the reprint of the issue was passed August 23, 1769, but was disallowed by the home government. In 1771 there was only $£ 98,895$ in circulation, the remainder having been lost or destroyed. ${ }^{4}$ The rate of exchange became fixed by 1731 at seven to one, and it so remained until the fall of the royal government. $£ 100$ sterling was equivalent to $£ 700$ currency, or $£ 133 \frac{1}{3}$ proclamation money.

Other attempts were made to increase the amount of legal tender currency, but they all failed. Thus in May, 1736, and again in June, 1746, acts were passed for stamping and issuing $\$ 210,000$ in bills of credit, based upon the same principle as the bank act of 1712 . Both contained saving clauses, but the most determined efforts failed to secure the approval of the home government. ${ }^{5}$

I Statutes, IX, 778.

${ }^{2}$ Ibid., 1II, 305-30T.

3 Ibid., $702-704$.

Ibid., IV, 312-314; Public Records, Ms., XXXII, 351, 357; Com. House Journals, Ms., XXXVIII, 490, 566-567.

5 Statutes, III, 423-430, 671-677; Public Records, Mls., XIX, 15-16, 214-216, XX, 124-126, XXII, 265-267, XXIII, 5-6, 56-61, 270-275, 281-2s2, XXVI, 30-31 ; Chalmers, Colonial Opinions, 425-428. 
Parliament passed a statute in 1751 prohibiting the New England colonies from issuing any more bills of credit, except for current expenses, when they must be redeemed within two years, or for war purposes, when they must be redeemed within five years. These were not to be a legal tender for private debts, although the bills already in existence might continue to be so. For assenting to currency acts which were contrary to the provisions of this statute, colonial governors were liable to dismissal from office. ${ }^{1}$ Practically the same restrictions were placed on the other colonies by instructions to their governors, but the statute was not extended to them until $1764 .^{2}$

The colonies took advantage of this power to issue limited legal tender bills redeemable in a specified time. Indeed several issues had been made in Sonth Carolina before the passage of the parliamentary statutes. They were known there as public orders, and were made receivable by the treasurer in payment of all taxes and duties.

When the fourth intercolonial war began in 1754 , South Carolina, along with the other colonies, was asked to make some provision for the general defense of America. The assembly resolved to issue $£ 40,000$ in public order's, redeemable in seven years. Governor Glen informed them that his instructions forbade his assenting to any act for issuing paper currency except with a saving clause; but as the case was urgent and would not admit of delay, he was willing to approve

1 Statutes at Large, 24 George II, chap. 53.

2 Ilid., 4 George III., chap. 34 . 
the measure under one condition. The condition was that the issue should be made in accordance with the act of parliament of 1751, that is the bills must not be made legal tender in the payment of private debts and ample provision must be made for redemption within five years. This statute, to be sure, did not extend to the souther'n provinces, but he was of opinion that it expressed the general policy of the home government. The assembly became very angry and threatened to make complaints in England against Glen. They finally gave way, however, and passed the bill in the form demanded. $£ 33,600$ were issued, redeemable in five years. ${ }^{1}$

The following table will show the amounts issued at various times and the provisions made for sinking them. The dates in the last column represent the time limits within which the respective issues were by law to be called in and redeemed. With the exception of the last two issues, all were redeemed with commendable promptness:

Date of Issue.

1731, Aug. 20,

1737 , March 5,

1740, April 5,

1740, Sept. 19,

1742 , July 10 ,

1745 , May 25,

1755 , May 20 ,

1757, July 6,
Amount.

$£ 104,775: 1: 33 \%$,

35,010 ,

25,000 ,

11,508 ,

63,000 ,

20,000 ,

33,600 ,

229,300 ,

$\begin{array}{cr}\text { Sinking Fund. } & \text { Sunk by } \\ \text { Duty on negroes, } & 1738^{2} \\ \text { Anuual tax, } & 1742 \\ \text { " " } & 1745 \\ \text { " " } & 1745 \\ \text { " " } & 1752 \\ \text { Fortification fund, } & 1750 \\ \text { Annual tax, } & 1760 \\ \text { " " } & 1762\end{array}$

1 Com. Housc Joumals, Ms., XXX, 102, 118-119, 478, 507-512; Public Records, Ms., XXVI, 18t-202; Statutes, 1V, 18-19.

2 Most of this issue was redeemed by 1738 , as provided by law. Then there seems to have been a delay for a few years and the remainder canceled between 1745 and 1750 . 
Date of Issue.

1760 , July 31 , 1760, Aug. 20, 1767, April 18, 1770 , April 7 ,
Amount.

$316,693: 2: 5$,

125,000 ,

60,000 ,

70,000 ,
Sinking Fund. Annual tax,

Sunk by

1765

1765

Add. duties on rum, etc., $17 \% 2$

Gen. duty fund,

\section{$1775^{1}$}

The greater part of these bills were issued either for actual war purposes of for strengthening the defenses of the province. For example, the issue of $173 \bar{\tau}$ was to defend South Carolina and Georgia against a possible attack by the Spanish and Indians, the two of 1740 to aid General Oglethorpe's expedition against St. Augustine, that of 1742 to defend Georgia against the Spaniards, and those from 1755 to 1760 to earry on the French and Indian war. The $£ 20,000$ issued in 1745 for repairing the defenses of the town anticipated the regular fortification fund. The issue of 1731 has already been discussed. It was to pay the public debts for the preceding four years. The $£ 60,000$ printed in 1767 were used to build an exchange and custom house and a new watch house in Charleston, the $£ 70,000$ in 1770 to build the court houses and gaols made necessary by the circuit court act of 1769 .

In addition to the bills of credit and public order's, there was a third form of paper currency which served as a medium of exchange, the so-called tax certificates. After the annual revenue bill was passed it would often

1 Statutes, III, 334-341, 461-464, 546-553, 577-579, 595-597, 653656, IV , 18-19, 45, 113-12S, 144-148, 257-261, 323-326. Much valuable information is to be derived from committee reports of $1749,1764,1774$ and 1775. Com. House Journals, Ms., XXV, 13S-143, XXXVI, 216-219, XXXIX, 108, 244. In 1774 there was still outstanding $£ 51,345$ of the

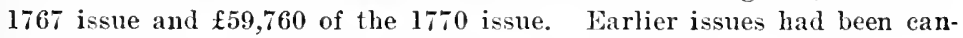
celed except for a few orders, which were probably lost. 
require several months to assess and collect the taxes. During the latter part of the colonial period, the tax bills regularly provided for the issue of certificates of indebtedness to the various public creditors. These were received at the treasury in payment of taxes.

This custom was utilized by the assembly in 1774 to ontwit Lientenant-Governor Bull and the council. A tax bill had not been passed in several years. The assembly ordered all public accounts to be audited, and then, without legal sanction, issued certificates to the public creditors, to be provided for in the next tax bill. The certificates were signed by the clerk and five members of the assembly. Several patriotic merchants and planters agreed to accept them in payment of debts, and they circulated side by side with the full legal tender's. Even the crown officials received them on their salaries. ${ }^{1}$

In concluding this section on the monetary system a brief summary may be of service. The English pound sterling was the standard of value, though very little English money was ever in circulation. Trade with the West Indies and South America brought in a great many Spanish, French, and Portuguese coins. There was a tendency in all the colonies to rate them high in order to get more than their neighbors did. The result was a proclamation, issued by Queen Anne in 1704 and enacted into a parliamentary statute in 1707 , establishing the maximum value which could be

${ }_{1}$ Com. House Journuls, Is., XXXIX, Part II, 162-161; Public Reeords, Ms., XXXIV, 36-40. This subject is discussed more in detail in the final chapter. See pp. 393-394. 
placed upon foreign coins. This fixed the ratio of proclamation money to sterling at four to three, or, to put it in another form, $£ 100$ sterling was equivalent to $£ 133 \frac{1}{3}$ proclamation money.

The internal business of the colony was carried on with paper currency. Full legal tender bills of credit were first issued in 1703. Subsequent emissions increased the amount to $£ 106,500$ by 1731 , and it remained at that figure until the Revolution. After 1731, the ratio to sterling was seven to one. Numerous issues of limited legal tender public orders were made between 1731 and 1770. Inasmuch as they were received in payment of taxes and were regularly redeemed in the time provided by law, they circulated at par with the bills of credit. Another form of paper money was the tax certificates issued to anticipate the collection of the annual tax. Similar to these were the certificates issued in 1774 on the sole authority of the commons house of assembly.

The struggle over the paper money question strengthened the antagonism between the ereditor and debtor classes. It made the merchants of Charleston the natural allies of the crown. His Majesty lost their support, partly because he failed to reward them with positions of trust and responsibility in the province, and partly because he protected them so well from the cheap money schemes of the planters that they became oblivious of danger.

\section{B. Revenue System}

The revenues of the province were derived from taxation, direct and indirect, fees, fines, licenses, and quit rents. 
Direct taxes were levied on land and negroes by an annual tax law. Until 1732, the law was passed during the year for which provision was being made, but, after that date, not until the year had closed. The method of procedure in framing a tax bill was about as follows: At their meeting in the fall, the commons house of assembly appointed a committee to examine petitions and accounts, a committee on the estimate of the public debts, a committee to examine the treasurer's accounts, and a committee to bring in a tax bill. The last mentioned committee presented a bill, which at once passed its first reading, with blanks left to insert the amount, and was sent up to the council. An advertisement was inserted in the Gazette, notifying all who had claims against the public that they must deliver their accounts, properly attested, to the clerk of the house before a certain date, usually January 1. As the accounts came in, they were read before the house and referred to the committee on petitions and accounts. After a period varying from a few weeks to several months, this committee presented a report consisting of a list of all the accounts submitted to them, numbered in regular order, and also their opinion on each separate case. The whole house then considered the report paragraph by paragraph. Most of the items would be accepted, some rejected, some recommitted, and occasionally an allowance would be made which the committee had refused. Other accounts would come in later, and the committee often made a second and even a third report. Some special accounts were allowed by the house without going to the committee at all. 
The committee on the estimate of the public debts next reported a tabulated schedule of the expenses of the government for the year, including the accounts already approved by the house, as well as provision for the public officials, scout boats, rangers, forts, and other charges.

A report from the committee to examine the treasurer's accounts would now be received, setting forth the amount of money in the treasurer's hands arising from the surplus of the previous year's tax, from the general duty act, and from the duty on negroes. This would be applied toward defraying the annual charges, and the tax to be raised was decreased to that extent. The amount of the levy having thus been determined upon, a committee would be appointed to apportion it between Charleston and the country.

The house was now ready to pass the tax bill through its second reading, the blanks being filled with the sum mentioned in the schedule of charges, less the amount already in the hands of the treasurer. The council passed it on its second reading and sent it back to the house, together with a separate schedule of amendments, ${ }^{1}$ which were almost uniformly rejected. The bill next passed both houses on its third reading and was sent back to the assembly to be engrossed. Finally, the members of the assembly went to the council chamber in a body to see the governor sign it. By this act, the bill became a law. Certificates, receivable in pay-

1 This method of suggesting amendment, as we have seen, was adopted December 11, 1739. 
ment of taxes, would now be issued to all the public creditors. ${ }^{1}$

Coming to the bill itself, let us consider briefly that of December 18, 1739, which may be regarded as typical. $£ 35,833: 6: 11 \frac{3}{4}$ currency was to be raised, one-sixth by the inhabitants of Charleston and five-sixths by the country people. A tax of ten shillings per head was levied on all negroes and other slaves within the province, and of ten shillings per hundred acres on all land, except that appropriated to churches and free schools, town lots outside Charleston plat, and the lands of new settlers in the frontier townships and on the Welsh tract upon the Pedee river. Owners of land and of slaves outside of Charleston were required to render a particular account thereof in writing to the inquirers and collectors of their respective parishes or tax districts, on or before the second Tuesday of the following February, and to pay their taxes not later than ten days after the second Tuesday in March. From one to three inquirers and collectors were appointed for each parish or tax district, except St. Philip's Charleston, which had three inquirers and five assessors and collectors. ${ }^{2}$ The Charleston inquirers were ordered to take an account of the real estate and slaves belonging to the inhabitants of the town, whether the same were within or without the limits of the parish. All with-

${ }_{1}$ Com. House Journals, IIs., XVII, passim. The account just given is based upon the procedure followed in framing the tax bill of $1741-42$. The fiscal year began March 25 .

2 In early times there was a double set of these officials for the country also, but after the tax began to be rated solely on land and slaves there was little need for inquirers. 
out the limits were assessed in the country tax; all within, in the town tax. On the last Tuesday in February the assessor's met at the new court house, received the report of the inquirers, and assessed the Charleston quota on the "real and personal estates, stocks and abilities" of the people. The persons so assessed were required to pay their taxes to the assessors and collectors on or before the third Tuesday in April.

In addition to their share of the general tax, the people of Charleston were further required to raise $£ 1,827: 8: 8$ currency for building a workhouse and maintaining the town watch. ${ }^{1}$ Masters of vessels and transient traders contributed to the tax according to the amount of goods which they imported into Charleston.2

This act is a fair sample of all those passed during the royal period. Others differ in slight details. By the acts of May 29, 1736, and March 5, 1737, a poll tax of seventeen shillings six pence currency was levied on all white males between the ages of twenty-one and sixty, except settlers in the new townships. ${ }^{3}$ The extraordinary expenses of the French and Indian War caused a wide extension of the domain of taxation. The act of May 19, 1758, not only increased the rate on land and slaves, but it also imposed a poll tax on free negroes and introduced the income tax feature. A tax was levied on annuities, money out at interest, the profits of country storekeepers, and the incomes of physicians and surgeons. ${ }^{*}$ In 1760 this was extended

1 A rude, imperfect system of police.

2 Statutes, III, 527-541.

3 Ibid., 438-439, 473.

I lbid., IV, 54. 
to all trades and professions except that of the clergy, and a tax was also imposed upon the value of lots, wharves, and buildings in towns, villages, and boroughs. ${ }^{1}$ Though the rate was reduced after the war, these taxes were kept up until the passage of the last tax bill in 1769 .

The amount raised per annum by direct taxation ${ }^{2}$ varied from a few hundred pounds to more than $£ 284,000$, according to the size of the province and whether it was at peace or war. The regular expenses of the govermment were small during the proprietary period and were usually provided for by quit rents, customs duties, liquor licenses, and fees, direct taxation being rarely resorted to except in emergencies. Taking a number of years at random, we find the amount of taxes levied to be as follows:

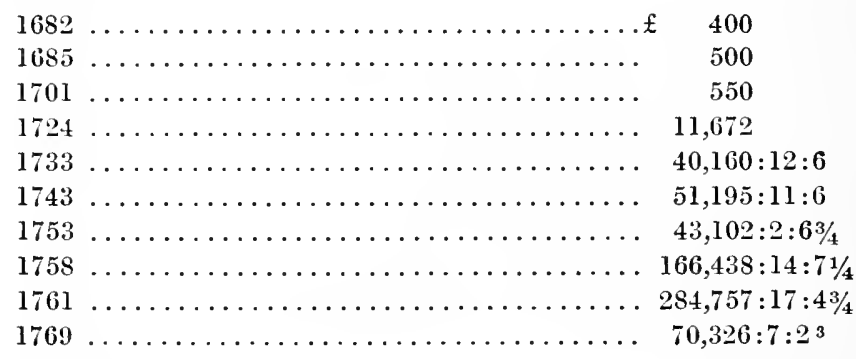

1 Statutes, III, I29.

2 This term is here used in its cconomic sense to denote a tax which cannot ordinarily be shifted. I have never found it in any of the jomrnals, records, or statutes of the time. The chief sources of taxation, however, were land and slaves, and it is very probable that the South Carolinians in the convention of 1787 thought only of these when the term direct tax was used.

${ }^{3}$ Ibid., II, v, 182, III, 206, 352, 597, IV, 6, 53, 155, 315. 
Of indirect taxes the most important were the import and export duties. A small export duty on deer, beaver, otter, fox, boar, and raccoon skins was imposed by an act of September 26, 1691. ${ }^{1} \quad A$ s early as 1695, there was an import duty on liquors, tobacco, and provisions. ${ }^{2} \quad$ The earliest general duty law preserved, that of May 6, 1703, provided an extensive tariff schedule. Thus specific import duties were imposed on wine, beer, cider, ale, molasses, sugar, flour, biscuit bread, tobacco, salt fish, cocoanut, logwood, brandy, and numerous other articles; an ad valorem duty of three per cent. on all imports not enumerated, salt excepted; and a duty of ten shillings per head on negro slaves brought directly from Africa, and twenty shillings on those brought from other places." The ad valorem auty was based on the valuation of the goods at the place from which they were imported, as shown by the shipper's invoice. The export duty on furs and skins was continued and a duty was levied on the exportation of Indian slaves and cedar timber. To encourage shipbuilding, it was provided that vessels built and uwned in the province should pay half duties, and those built elsewhere, but owned in the province should pay twothirds. ${ }^{4}$

1 Statutes, II, 64-68.

2 Ibid., 96.

3 The principal object in making this distinction was the desire to check what was threatening to prove a very serious evil. The settlers to the northward were beginning to regard South Carolina as the best place to dispose of their criminal and unruly slaves.

s Ibid., 200-206. 
This act remained in force until replaced by a similar one, June 30, $1716 .^{1} \quad$ The ad valorem duty on nonenumerated goods was increased five per cent. A law of December 11, 1717, not only further increased this to tin per cent., but also raised the specific duties. By an additional act of the same date, ships built and wholly owned in the province were allowed to carry all goods duty free, those built in the province and owned elsewhere were to pay one-half the regular rate, and those built elsewhere, but owned in the province, three-fourths. ${ }^{2}$

The British merchants and ship-builders of course complained of this attempt of the colony to apply the principles of protection. The king in council, on the recommendation of the Board of Trade, declared the objectionable acts null and roid and forbade the proprietors and the colonial assembly to make any attempt to enforce them. Governor Johnson was at once notified by the proprietors that they had been pleased to repeal the laws in question. ${ }^{3}$

A new measure, passed March 20, 1719, admitted goods from Great Britain and Ireland free of duty. For some reason this was also repealed by the proprietors, but was kept in force until replaced by the act of $1721 .^{4}$ All discriminations were removed by a law of 1723 , and the result was a decided increase in the

1 Statutes, II, 649-661.

2 Ibid., III, 27-30, 32-33.

${ }^{3}$ Public Records, Ms., VII, 116-117, 121, 122-124. 131-133; Chalmers Colonial Opinions, 586-587; Statutes, III, 30-31, 33 .

${ }^{4}$ Statutes, III, 56-69, 159-170. 
revenues. ${ }^{1} \quad$ Subsequent acts were passed in 1740 and 1751, the last being the well known general duty law, which was continued from time to time until March 4, $1776 .^{2}$

A large part of the revenue arising under these laws was appropriated to specific purposes while the remainder went into the public treasury. The duty on negroes was intended to be partially prohibitive, since the rapidly increasing slave population was a menace to the province. The fund derived from this particular source was, by the laws of 1740 and 1751, mostly appropriated toward bringing poor whites from Europe and settling them in the frontier townships. The law of 1751 applied one-fifth of the sum to the payment of bounties for the encouragement of ship-building in the province. Out of the duties on liquor and various goods imported and exported came the yearly salaries of the ministers, clerks, and sextons of the different parishes, and of the masters of the free school in Charleston, and annual grants of $£ 1,500$ for the building of St. Michael's church, $£ 200$ for the erection of a parsonage, $£ 200$ for keeping St. Philip's church in repair, $£ 2,500$ for building a state house, and $£ 5,000$ for fortifications. The surplus went into the public treasury. ${ }^{3}$ The duties for the year ending February 15, 1725, amounted to $£ 14,991: 4: 3$ currency, ${ }^{4}$ and for the year's 1746,1747 , and 1748 averaged $£ 23,848 .^{5}$

1 Statutes, III, 193-204.

${ }^{2}$ Ibid., 556-56s, 739-751, IV, 3S-42, 264-265, 332.

${ }^{3}$ Ibid., III, 742, 749-750.

4 Public Records, Ms., XI, 402.

${ }^{5}$ Com. House Journals, Ms., XXV, 84-S5. These figures are expressed in currency. To get the sterling value, divide by seven. 
The revenues of the province were further increased by a duty of one-half pound of powder per ton on all ressels coming into the harbor, and by small license fees required of retail liquor dealers and Indian traders. ${ }^{1}$ These taxes were levied by acts of the general assembly and collected by provincial officials. In addition there were the fees of the various crown and provincial officers and the usual fines and forfeitures, likewise regulated by statute, and finally, the quit rents, fixed by contract between the proprietors and settlers, or, after 1729 , between the king and settlers, ratified by the laws of 1696 and 1731, and collected by officials appointed by and acting under the proprietors or the crown.

Taking the year 1746 as an average, we find the total revenue approximately as follows:

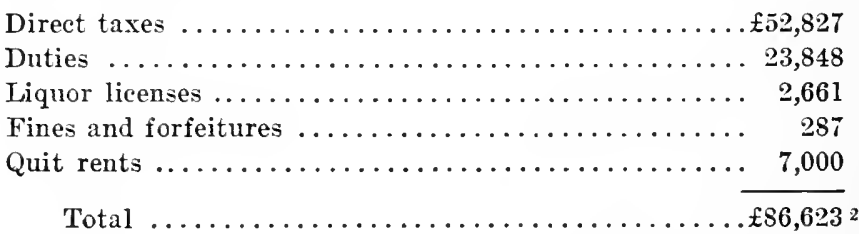

A small additional sum was derived from the sale of licenses to Indian traders, but the exact amount is not known. It was, perhaps, barely enough to pay the salary of the Indian commissioner and other necessary expenses of the system.

I Statutes, II, 20-21, 42-44, 82-84, 85-86, 113-115, 198-199, 309, III, 142-143, 419, 58s-590.

${ }^{2}$ Ibid., III, 696 ; Com. House Journals, Ms., XXV, 84-85, XXII, 593 ; Public Records, Ms., XX, 355; Ms. rolume in the office of the Secretary of State entitled Quit Rents, 23. 
The dynamics of the revenue system is practically the constitutional history of South Carolina. The opposition to the parliamentary schemes of taxation after 1763 was not a mere pretext to bring on rebellion and secure independence. It was the assertion of a principle which for many years had been a part of the unwritten constitution of the colons. In tracing the development of this principle, we are reminded more and more of the similarity between the history of the province and that of the mother country.

Although the currency question was all-important during the administrations of Nicholson and Middleton (1721-1730), there were several disputes over the subject of money bills. The estimate of expenses for the year 1722 was made by a joint committee from both houses. The assembly made some changes and sent it to the council. The confused ideas in regard to the position of the council are shown by the fact that the message in reply was signed by the governor. That is, as a member of the second branch of the legislature, he was considering a measure which he must ultimately pass upon as the third branch. Objection was made to sereral articles in the estimate, particularly one allowing Mr. Joseph Boone $£ 1,500$ for his services as agent in England, and another allowing Mrr. Trott $£ 1,000$ for printing the laws of the province. The point to be noted is that the lower house considered these amendments and alterations and agreed to those relating to Boone and Trott. ${ }^{1}$

${ }^{1}$ Com. House Journals, Is., VI, 191-192, 195-196; Statutes, III, 191. 
A controversy in 1723 over the salary of the clerk of the council resulted in a further confirmation of the right of the upper house to amend money bills. During the proprietary period, the secretary of the province had also acted as clerk of the council, but on Nicholson's arrival a separate clerk was appointed under a royal patent. Regarding this as a useless multiplication of offices, the assembly appropriated only $£ 200$ for Mr. Tunley, the clerk of the council, while Mr. William Blakeway, their own clerk, was to receive $£ 400$. On the refusal of the lower house to increase Tunley's allowance, the council reduced Blakeway's to $£ 300$. This settlement was finally accepted: ${ }^{1}$

The dispute was renewed the following year, and Mr. Tunley was allowed only $£ 100$, in spite of Governor Nicholson's remonstrances. The Governor was made to realize that his opposition would merely delay the passage of the bill and consequently the payment of his own salary. ${ }^{2}$

Still another recognition of the council's right to amend revenue bills was made in 1725 . The lower house again approved Mr. Boone's claim for £1,500. It was unanimously rejected by the council, May 31 , on the ground that Boone, while agent in England, had tried to negotiate the sale of the province, instead of permitting it to come under the control of the king. In reply to the request of the commons for a conference committee on the subject, they said that it would be

${ }^{1}$ Council Journals, Ms., II, 228, 239-240; Com. House Journals, Ms., VI, 221-225.

${ }^{2}$ Com. House Journals, Ms., VI, 458, 469. 
useless, since their decision was final. Furthermore, they declared that they had a right to agree or disagree to any order, and that if the lower house should insist upon a conference on every subject that came up, nothing that the council did would be conclusive. The assembly acknowledged their right to a negative vote on all orders, but insisted that they had an equal right to demand a conference. The assembly adjourned from June 1 to November 1. A similar order in favor of Boone was sent up on the 18th of December, but it was ignored by the council. ${ }^{1}$

From these cases, it is clear that public claims were first passed upon by a joint committee of the two houses, and that the assembly repeatedly recognized the council's right to amend. We may say, then, that at the beginning of the royal period the two houses had exactly equal control over money bills. The lower house carried their point in reducing Tunley's allowance, but they failed in the Boone case.

The first encroachments of the assembly along this line were made during the turbulent administration of President Middleton. The anmual tax bill passed the commons house on its first reading, November 16, 1725, and, according to custom, was sent to the council for its first reading there. It received its second reading in the commons December 1 , and was again returned to the council. Apparently it had been customary for the council to make such amendments as they desired on the second reading. At any rate, they inserted several on this occasion. The assembly struck all of them out

'Com. House Journals, Ms., VII, 240; Council Journals, Ms., III, $31-39,248,327$. 
and passed the bill on its third reading. When the bill came up for its final reading in their house, the council again inserted the amendments. A deadlock was now threatened. The assembly declared that it was unparliamentary to amend a bill on its third reading. The council maintained that the conduct of the lower house was also unparliamentary in striking out their amendments without asking for a conference. Such a procedure would deprive them of their undoubted right of framing, altering, and amending bills. In reply, the commons called attention to the fact that in Great Britain bills were amended only by the house in which they originated, and that amendments desired by the other house were sent to them before being placed in the bill. As this was the constant maxim in measures of all kinds, the argument on their side was still stronger in the case of money bills. The council weakened the force of this precedent by pointing out the great difference between the method of procedure in Great Britain and that in the province. In Great Britain, as bills were read three times in one house before being sent to the other, it was necessary that all amendments should be concurred in by the house where the measure originated before being made a part of the bill. The custom in the province, however, except for a short time during Nicholson's administration, had alwars been to read the measure alternately in the two houses. ${ }^{1}$

President Middleton interposed as a peacemaker and suggested that a joint committee from the two houses should meet and consider the best method of passing

${ }^{1}$ Com. House Journals, Ms., VII, 256, 25i, 295, 29S-303, 306-307. 
bills. The committee met, but could reach no agreement. The commons determined not to pass the revenue act at all unless they could carry their point. Accordingly, they asked the president to ratify the other lars before him and to conclude the session as soon as possible. Middleton insisted that the method of passing bills should first be settled and threatened to postpone the ratification of all measures until that was done. After some discussion, however, the laws were ratified on December 9, and the assembly was prorogued to the next dar.'

The dispute was continued into the new session. The council again amended the bill on its second reading. After some debate in the commons, "the question was put, whether it is the opinion of this house that the Council shall make any alterations in Tax Bills." This was carried in the negative, and a message sent to the council to that effect, together with the bill. The council refused to receive the bill until it had been read a third time in the assembly. At the same time they sent down a long message in defense of their right to amend revenue measures, citing the passage in the thirty-fifth article of Governor Nicholson's instructions which expressly gave them an equal power with the lower house in framing, amending, and altering money bills. In conclusion, they threatened to make an appeal to the king for a final settlement. ${ }^{2}$

The commons now passed the measure on its third reading with all the amendments struck out. The council yielded under protest, and consented to its final

1 Com. House Journals, Is., VII, 304-310.

2Itid., 314-315. 
passage, alleging as a reason the necessity of securing supplies for the support of the gorernment. They declared, however, that they would lay the whole affair before the crown. The lower house begged them to represent the matter in its true light and let the king know that it was not an act for stamping bills of credit, but for a tax to be raised by the people. ${ }^{1}$ At a joint meeting of the two houses held on December 18 for the purpose of ratifying the bill, Speaker Broughton adranced a very ingenious interpretation of the gorernor's thirty-fifth instruction. It allowed the council an equal power with the assembly in framing, altering, and amending money bills, and enjoined the governor not to allow the assembly or any of its members any power or privilege which was not permitted by the king to the House of Commons or the members thereof in England. By a process of negative reasoning, Broughton argued that the assembly in South Carolina possessed all the powers and privileges of the House of Commons. As the Commons in England had the sole right of framing, altering, and amending money bills, the representative assembly of South Carolina had the same right. He went on to say that the term money bills used in the instruction must mean paper money bills and not pure tax measures. ${ }^{2}$

President Middleton in his closing speech severely criticised the commons for their encroachments in the face of a positive instruction, and prorogued them to the second Tuesday in March. ${ }^{3}$

I Com. House Journals, Ms., VII, 316-31'.

2 Ibid., 319-321.

${ }^{3}$ Council Journals, IIs., III, 252-253. 
This was the greatest victory yet achieved by the assembly. It was the first time that they had definitely denied the right of the council to amend money bills. Although there were numerous other disputes over the question, the advantage thus gained was never given up.

The remainder of Middleton's administration was taken up with the controversy between the two houses over the issue of bills of credit. Reference has already been made to the arrival of Governor Johnson in December, 1730, and to the passage of the currency and quit rent acts in 1731 . The common interests of the council and assembly on the land question restored harmony between them.

The dispute in regard to the salaries of President Middleton and Chief Justice Wright continued for several vears. ${ }^{1} \quad$ Still there was no serious conflict over the question of money bills until 1735. A message from the council, dated February 7 , reminded the lower house that no provision had been made for the chief justice in nearly three years and urged them to consider the matter. Motions to allow Judge Wright $£ 1,400$, and then $£ 700$, were voted down, and finally it was decided to strike his name out of the estimate entirely. On Narch 27 another message was received from the council complaining that they had received no answer to their message of February 7, and stating that they could not read the tax bill a second time until provision was made for the chief justice. ${ }^{2}$

1 For a discussion of this subject see Section I, Land System, Chapter II; Section II, Government, Chapter I.

${ }^{2}$ Com. House Journals, Ms., IX, 53-59, 133, 183. 
The assembly now requested the immediate return of the tax bill, as the members wished to finish all business and go home for the Easter holidays. The bill was soon brought down, endorsed as read and passed a second time in the council. On proceeding to read it a third time, the house found that some changes had been made. The sum $£ 42,992: 13: 6$ in the title and preamble had been changed to $£ 45,092: 13: 6$, and in the estimate there was inserted an item of $£ 2,100$, salary of the chief justice for three years at $£ 700$ per annum. The bill thus altered was unanimously rejected, and the committee on the tax bill was ordered to draw up resolutions. ${ }^{1}$ A day later, the committee made the following report through their chairman, Mr. Charles Pinckney:

"Resolved, That it is the Opinion of this House that it is the inherent right of every Englishman not to be charged with any Taxes or Aids of Money, but what are given and granted by his Representative in Parliament.

"Resolved, That the House of Commons have the Sole Right and Power over the Moneys of the People, and of giving and granting or denying Aids or Moneys for the Public Service.

"Resolved, That the House of Commons have the first commencement and consideration and the Sole Modelling in their House of all Laws for imposing Taxes, and levying and raising aids of Money upon the People for the defense and support of the State and Government.

"Resolved, That the foregoing Privileges are some of the Fundamental Laws, Rights, Libertys, and Customs of the People of England, confirmed by many Statutes and Acts of Parliament.

${ }^{1}$ Com. House Journals, Ms., IX, 186-1ss. 
"Resolved, That His Majesty's Subjects of this Province are entitled to all the Libertys and Privileges of Englishmen.

"Resolved, That the Commons House of Assembly in this Province, by Laws and Statutes of Great Britain made of force in this Province, and by Acts of Assembly of this Province, and by ancient Usage and Custom, have the same Rights, Powers, and Privileges in regard to introducing and passing Laws for imposing Taxes on the People of this Province as the House of Commons of Great Britain have in introducing and passing Laws on the People of England.

"Resolved, That after the Estimate is closed and added to any Tax Bill, that no additions can or ought to be made thereto, by any other Estate or Power whatsoever, but by and in the Commons House of Assembly.',1

These resolutions were sent to the council, together with a message denying their right to amend money bills. $^{2}$

In order to give the assembly time to recover from their anger, they were prorogued from March 29 to April 15. On the 16th a new tax act was read, passed the first time, and sent to the council. They passed and returned it the next day. ${ }^{3}$ The old dispute was renewed. The council again cited Nicholson's thirtyfifth instruction, referred to in the election act, as their authority for claiming a right to frame, alter, and amend money bills, and urged the house to send up the estimates for their consideration. ${ }^{4}$ A committee of the assembly, appointed to search the journals for

${ }_{1}$ Com. House Joumals, Us., IX, 190-191.

2 Ibid., 194.

3 Ibid., 201, 203.

- Council Journals, ifs., VI, 36-97. 
precedents, reported verbally on the $23 \mathrm{~d}$. They stated that, in the beginning of Middleton's administration in 1725, the council claimed the right of framing, altering, and amending money bills, but that the lower house would never agree to any of their amendments. "That a Tax Bill was lost which had been amended by the Council. And at another time when amendments were made in a Tax Bill by the Council, the lower house struck the same out and sent the Bill back as it was first framed in the Commons House; and that the Council in the end gave up the Point." A message to the council denied that the reference in the election law to Governor Nicholson's thirty-fifth instruction could give them any power "in derogation to the Fundamental Rights of the Commons House." As was usually the case in such controversies, the council finally yielded, and on April 25 the bill was passed on its third reading without alteration. It was ratified on the 28th. ${ }^{1}$

Governor Johnson died May 3, $1735,{ }^{2}$ and, in accordance with the royal instructions, was succeeded by his brother-in-law, Lieutenant-Governor Thomas Broughton.

For the second time the responsibilities of government fell upon a resident of the province. Broughton was more tactful and less obstinate than Middleton. In the main, he continued Jolnnson's policy. Taking a firm stand in defense of the royal prerogative, he was wise enough to see how far he could push his claims and when he must yield.

1 Com. House Journals, Ms., IX, 219-221, 25̄.

${ }^{2}$ Public Records, Us., XVII, 310. 
The dispute over the allowance to the chief justice was soon renewed. Judge Wright appealed to the British Board of Trade to see that his salary and arrears were paid. Having taken the matter under consideration and heard arguments from Mr. Fury and Mr. Yonge, agents of the province, Mr. Shelton, secretary to the late Lords Proprietors, and Mr. Hume, former speaker of the assembly, they issued an order, June 10, 1735, that a report should be prepared in favor of the petition. A warrant was issued by the queen providing that the chief justice should in the future be paid a salary of $£ 1,000$ currency per annum out of the quit rents. ${ }^{1}$

The annual tax bill passed its first reading in the council, January 30, 1736, and was sent down to the assembly, together with a message from the lieutenantgovernor, complaining that no provision had been made for the chief justice for four years, and calling attention to the fact that Her Majesty had in a special manner signified her pleasure therein. ${ }^{2}$ The house seems to have disregarded this appeal, for Broughton sent them another message on the 19th, expressing surprise that Wright's name was not in the estimate just sent up, and again reminding them of the royal pleasure. Along with this were enclosed copies of the report of the Board of Trade on Wright's petition, and of the queen's warrant for fixing a salary of $£ 1,000$ currency upon the chief justice. ${ }^{3}$

1 Public Records, Ms., XVII, 257-259, 319-321; Com. House Journals, Ms., IX, 535-536; Council Journals, Ms., VI, 359. The warrant was signed by the queen, probably while George II was on one of his trips to Hanover.

${ }^{2}$ Council Journals, Ms., VI, 177.

${ }^{8}$ Com. House Journals, Ms., IX, 535-536. 
Four days later, another communication was received from the lieutenant-governor stating that the delay of the council in reading the tax bill a second time was due to the fact that they were waiting for an answer to their message of the 19th. The assembly replied that they would consider the message when the tax bill was sent down to them and not before. ${ }^{1}$ The bill was accordingly passed and sent to them on the 25th. The message of the 19th, the report of the Lords of Trade, and the queen's warrant were then taken under consideration, and the question, "Whether the Chief Justice shall have any Allowance made to him in this Estimate," was carried in the negative. ${ }^{2}$ In a message to the council, they declared that the Lords of Trade had been imposed upon, for the chief justice had never been paid a regular salary, but only allowances for special services. Propositions to provide for him had been voted down for three years past and they could not now see any new reasons why he should be given an allowance. Broughton expressed great surprise that they should dare to say that their lordships had been imposed upon, and conclude that the queen's warrant afforded no new reason for providing for the chief justice. $^{3}$

A committee of the house reported a long message to be sent to the council giving five reasons why a regular salary should not be paid to the chief justice ont of the provincial treasury. The sum and substance was that in all the other provinces this official was paid either

\footnotetext{
${ }^{1}$ Com. House Journals, Ms., IX, 560-561.

2 Ibid., 567, 573.

s Ibid., 596-597, 615-616.
} 
by the king or by the proprietors. The report went on to state that, out of respect for Her Majesty's recommendation, they were willing to allow Wright $£ 700$ in full settlement of all his claims. In considering the report, however, the house struck out even this concession. ${ }^{1}$

The lieutenant-governor again sent down the queen's warrant, but it was at once returned. Broughton continued his remonstrances, and finally, on May 26, the assembly voted to insert this item in the estimate, "To the Chief Justice in full of all his Services, £700." The council having agreed, the bill became a law on May $29 .^{2}$

The three rears provided by law for the duration of general assemblies having almost expired, this assembly was dissolved on September 30, 1736, and writs were issued for a new election returnable November $10 .^{3}$ Among those elected were Charles Pinckney, Benjamin Whitaker, Isaac Mazyck, Maurice Lewis, William Trewin, Andrew Rutledge, and others who were becoming prominent in the affairs of the province. Charles Pinckney, who had drawn up the spirited resolutions maintaining the sole control of the lower house over money bills, was elected speaker. In his presentation speech he followed the precedent set by Captain Dry and demanded the preservation and protection of the known privileges of the house.

${ }^{1}$ Com. House Journals, Ms., IX, 651-656.

${ }^{2}$ Ilid., 662-663, 707, X, S, 11; Council Journals, Mfs., VI, 274-275; Statutes, III, 43S-448.

${ }^{3}$ Council Journals, $M$ s., VI, 300.

-Com. House Journals, Ms., X, 97-100. 
The question of the chief justice's salary came up once more. On December 17, Lieutenant-Governor Broughton sent down a message saring that Judge Wright had received only $£ 1, \pm 00$ for the five years of his service, though his predecessor, Mr. Allein, had been paid $£ 1,000$ yearly. Accordingly there was due $£ 3,600$, which he urged the house to provide, in obedience to Her Majesty's sign manual. He concluded with the information that the queen had ordered for the future that the chief justice should be paid $£ 1,000$ annually by the receiver-general out of the quit rents. The house replied that they had already donated $£ 700$ to Wright, which was pay in full for all of his claims.

The assembly won another victory during this session which was of still more constitutional importance. The tax bill passed its second reading in the house, February 8, 1737, and was sent up to the council along with the estimate for the year. ${ }^{2}$ The regular method of framing the estimate had long been by a joint committee on petitions and accounts chosen from both houses. In the South Carolina Gazette for January 18, 1735, there appeared an advertisement notifying all who had accounts against the public to bring them to the clerk of the commons house of assembly before the first Tuesday in February. Whether this was the beginning of the custom is not clear, but, at any rate, from this time on, accounts were examined by a committee of the lower house only, and the council had no share in framing the estimate.

I Com. House Journals, Ms., X, 347; Council Journals, Ms., VI, 35ร-359.

${ }^{2}$ Com. House Journals, Ms., X, 399. 
On February 23, the council sent down a message desiring a conference committee on the estimate. The commons replied that their house could not be justified by the usage of parliament in appointing a committee to confer with the council on supplies granted to His Majesty. To this the answer was returned that it was no new thing for the houses to confer on the estimates of the year, as would be seen by a perusal of their journals. The house was also reminded that accounts had formerly been examined by a joint committee of both houses, though the assembly had now assumed to themselves the power of examining them before a committee of their own house only. The lower house acknowledged that precedents might be found to support the claims of the council, but insisted that no precedent would ever be "able to supersede the rights which every Fnglish subject derives from the ancient and fundamental constitutions of the country on which he depends." Furthermore, the business of granting supplies to His Majesty and appropriating them to whatever purposes they thought proper was the sole and undoubted privilege of their house. The council passed the bill on its second reading, but sent down a protest against the claims of the assembly. ${ }^{1}$

Before it was finally enacted into a law, an absurd incident occurred which serves to show how tenacious the assembly were of their privileges and how ready they were to humiliate the council. The bill had its third reading in the lower house on March 1. A day later a message from the council was received com-

1 Com. House Journals, IS., X, 433-434, 439-440, 442-443, 447-448. 
plaining that the name of Mr. Secretary Hammerton had been erased from the estimate, and in a paragraph marked (A) some absurd and ludicrous lines inserted by the clerk of the assembly, which were very insulting and unparliamentary. ${ }^{1}$ In reply the assembly said that, in the original estimate, Mr. Hammerton had been addressed simply as "John Hammerton, Esq." He became angry at this, and they changed it to "The Honorable John Hammerton, Esq." As the council had taken umbrage, they beg to be told all the gentleman's styles and titles so ther can address him accordingly. The message added that some other words were added during the debate, which were afterwards struck out by the house. The offensive words having been expunged before the bill was sent up, they could not, contended the assembly, be taken notice of by any rules of parliamentary procedure. ${ }^{2}$

In spite of this dispute, the bill passed the council on March 2. They insisted, however, that the author of the witticism should be reprimanded and expressed regrets that the lower house should speak so disrespectfully of the council and its members. Lieutenant-Governor Broughton sent a message to the same effect. ${ }^{3}$ The assembly became very indignant and at once drew np and transmitted to the conncil a long series of resolutions, of which the following are fair samples:

"Resolved, That the Freedom of Speech and Debate on proceedings in the Commons House of Assembly ought not

${ }^{1}$ Council Journals, Ms., VI, 45S, 459.

2 Itid., 462-463.

s Ibid., 469-470. 
to be examined and questioned in any place out of the said House.

"Resolved, That the Governor" of this Province ought not to take notice of any Proceedings in the said House but when the same is properly laid before him in a Parliamentary way.

"Resolved, That it is a Breach of the Privileges of this House for the Governor or Commander in Chief for the time being to take any notice of any differences between the two Houses about their Privileges, with which he is not concerned.

"Resolved, That this House will not further proceed upon any business before them, until they have received satisfaction concerning their Privileges."

Broughton hastened to assure them that he had no intention of invading the rights and privileges of the assembly, for they were the rights of all the commons of South Carolina and he would always support them to the utmost extent of his power.'

The assembly were not satisfied even after they had gained the sole power of framing and amending money bills. They must make sure that the money was spent for the purposes for which it was roted. Six thousand pounds were appropriated in 1737 for the expenses of an expedition against the Spaniards and Indians and provision was made that it should be paid out by the treasurer, only on orders drawn by the lieutenant-gorernor, council, and a committee of the assembly. As the council said, this was contrary to the governor's instruction forbidding the payment of an money from the public treasury except by warrant under his hand. The committee sat during the recess of the assembly,

1 Council Journals, Ils., VI, 4i0-4il.

2 Ibid., 472. 
and not only joined in signing warrants on the treasurer, but also took part in regulating the details of the expedition. ${ }^{1}$

Lieutenant-Gorernor Broughton died November 22, 1737. Arthur Middleton had died on the 6th of September, so the government now devolved upon William Bull, the eldest councilor. ${ }^{2}$ Colonel Bull presided over the government until Governor Glen's arrival in 1743. $\mathrm{He}$ was commissioned lieutenant-governor in June, 1738. There were three important constitutional advances made during his administration: the governor was excluded from the council when sitting in their legislative capacity; the assembly extended their control over money bills; and, finally, the assembly succeeded in electing a public treasurer against the will of the lieutenant-governor and council.

Reference has already been made to the resolution of the upper house, adopted April 11, 1739, not to enter into any debates during the presence of the governor or acting governor: ${ }^{3}$

The chief dispute orer a money bill also came in this year. The commons, as usual, took adrantage of the misfortunes of the province to force the council to agree to their encroachments. The naval war between England and Spain was about to begin in Europe, and it was naturally to be expected that hostilities would be resumed between the South Carolina settlers and

1 Council Journals, IIs., VI, 481, 487-494, XIII, 144-145; statutes, III, 484. See Chapter V, Militia and Defence, section on Indian Affairs, 220-221.

2 Public Records, Ms., XVIII., 312.

3 See Chapter II, The Legislature, 92-93. 
the Spanish colony at St. Augustine. The Spanish were in the habit of enticing slaves to run away from their masters and come to St. Augustine. They had orders from the king of Spain to free all negroes thus escaping and were forbidden to return them to their owners. Attempts to incite the slaves to rebel resulted in the Stono insurrection, September, 1739, in which over sixty lives were lost. ${ }^{1}$ While their country was thus subjected to dangers both without and within, the two houses of assembly spent the time disputing over powers and privileges.

An explanatory bill for keeping and maintaining a watch in Charleston was amended by the council on its second reading. The lower house struck out these amendments on their third reading, whereupon the council sent down a message stating that their conduct was very unparliamentary and asking for a conference to discuss the matter. ${ }^{2}$ In reply the assembly maintained that the measure under discussion was a tax bill and that the attempt of the council to amend it was unparliamentary. They concluded with the declaration that they possessed the sole power of framing bills for granting to His Majesty tases, aids, or subsidies, and amending or altering the same upon the first, second, or third reading whenerer they should think it fit and necessary. ${ }^{3}$

The dispute now turned upon another bill. An act for levying an import duty on negroes, liquor, and

1 See MeCrady, S. Car. under Royal Govt., 18j-187.

2 Council Journals, IIs., VII, 201-202.

${ }^{3}$ Ibid., 208-209. 
merchandise, usually called the general duty act, was amended in the council. The assembly at once advanced the plea that this also was a tax measure and could not be interfered with. With some show of spirit, the council declared that they would not suffer any law to pass their house until it had been submitted to such alterations as they thought necessary for His Majesty's service. ${ }^{1}$

Numerous messages on the subject passed between the houses. The council maintained that, by the thirtyfifth article of Governor Nicholson's instructions, made a law of the land by the election act, they possessed an equal right with the lower house in framing, altering, and amending money bills. The assembly, on the other hand. affirmed that they had all the powers and privileges of the British House of Commons and hence the sole control over all supply bills. The council now informed the assembly, that, as they eridently did not intend to proceed to business, they had adrised the lieutenant-gorernor to adjourn them for a time. The reply was that the commons house had the right to adjourn themselves, and that the king's power was to call, prorogue, and dissolve. Further, they said that, in answer to a request, they had just leceived permission from the lieutenant-governor to adjourn themselves. ${ }^{2}$

After a six months' vacation, the general assembly met again on May 29. A message was received from the upper house stating that the tax bill was before

1 Council Journals, IIs., VII. 215-216.

2 Ibid., 221-223. 
them for a second reading, but in the estimate annexed there was a list of sums of money to be paid to various people without expressing in many cases for what services. They went on to say that they could not proceed with the bill until all the accounts and vouchers were laid before them. Finally, there were many sums of money due to different persons which were not in the estimate at all. ${ }^{1}$

A committee of the lower house, appointed to draw up reasons in support of their privileges, made a report on June 5. The document fills fourteen closely written pages. Perhaps the most important part is a short paragraph in which the force of royal instructions is questioned. Speaking of the thirty-fifth article of Nicholson's instructions, they say:

"A Power to abrogate old Laws or impose new ones upon the People without their consent is a Prerogative that the Crown never exercised or assumed to itself over any part of the Realm. But a Concession that a Royal Order ean qualify or anywise alter a fundamental right from the shape in which it was handed down to us from our Ancestors, is an Acknowledgment of such a Prerogative to all Intents and Purposes. The power of raising and levying of money is of the many Privileges we enjoy, the most essential, and upon which all the rest seem to depend. If the Comer Stone is once removed, the Superstructure of course will fall to the ground." ${ }^{\prime 2}$

The dispute continuing, the council appealed to Lieutenant-Governor Bull to come to their aid. They said that the assembly had acted contrary to custom

1 Council Journals, M/s., VII, 226-229.

${ }^{2}$ Com. House Journals, Is., XII, 70, 84, 76-77. 
in refusing a conference on their amendments to the watch bill, in refusing to allow them to amend a duty bill as they had always done, in examining the treasurer's accounts without the aid of the upper house, and in examining petitions and accounts and putting them in the estimate without submitting them to the inspection of the upper house. Finally, they had heard that the commons questioned their authority to sit as an upper house. They called upon the lieutenant-governor to support the king's prerogative and either prorogue or dissolve the assembly. Bull replied that he could not consent to a prorogation as the duty law would soon expire and must be renewed at once. Further, that he would take no part in the dispute other than to send a copy of his instructions to the assembly. That body hastened to inform him that they had in no. ways acted contrary to the instructions and that they were ready to grant supplies to His Majesty. As the tax bill had been before the council since March 2 and they showed no inclination to return it, the assembly begged leave to adjourn to the first Tuesday in September. Colonel Bull saw that it would be useless for the houses to sit longer at that time and permitted the adjournment. ${ }^{1}$

Before the time for their meeting arrived, Bull heeded the advice of his council, dissolved the assembly, and issued writs for a new election returnable on September 12.2 On account of a yellow fever epidemic, a

1 Councit Journals, Ms., VII, 241-24s.

2 The journals make no mention of this, so the exact date of the dissolution cannot he found. At any rate a new assembly met on September 12. 
quorum could not be secured until the 6th of November. ${ }^{1}$ Charles Pinckney was again elected speaker.'

The first business to come up was in regard to the tax bill. It passed the house on its first reading and was sent to the council. They replied that they would not pass it until a committee from their house was allowed to join an assembly committee to consider petitions and accounts. In answer to this, the assembly agreed to send up the accounts, but said that they could not appoint a conference committee without giving up their rights as Englishmen. ${ }^{3}$ The council stood firm, and a legislative deadlock was the result. Finally, on December 8, after the tax bill had been before the council for a month, the houses agreed to appoint a joint committee to confer on a method of passing bills. The plan as adopted by both houses has been given in the chapter on the legislature. The chief question at issue was settled by an agreement that the council might draw up on a separate schedule such amendments as they desired to make to a subsidy bill. Those that were approved by the Iower house would be inserted in the body of the bill. Neither honse was willing to have the settlement regarded as a precedent. The council maintained that they had suspended their right to have a committee from their house meet a committee of the assembly on petitions and accounts only because the danger from foreign war and domestic insurrection made it necessary. The commons at once resolved that

${ }^{1}$ Public Records, Ms., XX, 192-194.

${ }^{2}$ Com. House Joumals, .Hs., XII, 105.

3 Ibid., 154-155, 161. 
the council had no right to appoint a committee to confer on petitions and accounts, and declared that they would not permit it at any time in the future. Furthermore, their house already possessed the sole control over money bills, and they had agreed to a conference on the subject merely to preserve harmony. ${ }^{1}$

After this compromise had been agreed upon, the tax bill was passed, December $1 \bar{i}, 1739$, and the assembly adjourned for the holidays.

The remaining four years of Bull's administration were quiet and peaceful, the appointment of a public treasurer having furnished the only serious cause for dispute between the houses. Early in March, 1743, Treasurer Gabriel Manigault sent a memorial to the general assembly asking leave to resign. By a statute of September 20,1721, the right of electing this official was, as we have seen, vested in the general assembly. ${ }^{2}$ An earlier act of 1707 giving the lower house the sole control was superseded. ${ }^{3}$ Relying upon the equal power thus guaranteed to them by law, the council sent down a message, March 24, recommending Colonel Othniel Beale for the vacancy. ${ }^{4}$ The assembly disregarded this communication, and, just one week later, resolved that Mr. Jacob Motte, a member of their house, should be public treasurer. Beale's name was not considered, though others were. Later in the day an ordinance was received from the council for appointing Beale. It was amended by the substitution of

1 Com. House Journals, Us., XII, 188-191, 195, 211-212, 222.

2 Statutes, III, 148-149. See introductory chapter.

s Ibid., II, 299.

${ }^{4}$ Com. House Journals, Ms., XVIII, 608-609. 
Motte's name and then returned. The council again inserted Beale's name and passed the ordinance on its second reading. The house did the same, substituting Motte's name. Re-inserting Beale's name, the council passed it on its third reading. Nothing more was done until April 9, when the council sent down a message expressing surprise that the house still retained the ordinance and urging the necessity of its immediate passage. The reply to this was that Manigault had not been given leave to resign, hence the office was not yet vacant. On the 26th, the assembly proceeded to a third reading of the ordinance and sent up a message desiring a conference. Committees were accordingly named by both houses. The assembly committee reported on the 28th that they could come to no agreement, since they adhered to Motte and the council committee to Beale. They were ordered out again and urged to use their best efforts to secure an agreement on Motte, but failing in this, to suggest William Cattell, Jr., as a compromise. The committee reported on the next day that the council committee would not agree on Motte, that they suggested Cattell, and the committee went back to their house for instructions.'

Motte now went to Beale and proposed to divide the profits of the office with him for three or four years, if he would go on his security and pay one-half of the clerk's wages. Beale agreed and promised to use his influence in Motte's behalf. A message was sent to the assembly on the 29th agreeing to Motte's election. ${ }^{2}$

1 Com. House Journals, Js., XVIII, 671, 6s1-682, 6s8, 691-692, 740$741,745,752,761-762$.

I Ibid., 769, 776-7\%. 
After the death of Governor Johnson in 1735, there was some trouble in securing a proper person to succeed him. Colonel Samuel Horsey was appointed early in 1738, but he died before his commission and instructions were completed. ${ }^{1}$ In November of the same year a commission was drawn up for James Glen. ${ }^{2}$ He did not come out to the province for several years, however, and the government, as we have seen, was administered by Lieutenant-Governor Bull. Glen was a young Scotchman of some tact and ability, but utterly without experience in colonial affairs. During his administration of thirteen years, the assembly increased their influence at the expense of the governor and council. Strange to say, no one was more responsible for this than the governor himself, for he made the serious mistake of quarreling with his council and trying to make friends with the assembly. The dispute with the council has already been considered in another connection. ${ }^{3}$ It grew out of their determination to exclude the governor from the sittings of the upper house. His denial of their right to sit alone as a branch of the legislature gave great encouragement to the assembly.

On the whole, Glen's administration was characterized by very few specific encroachments of the assembly upon the governor and council. It was rather a period during which the assembly continually made use of the powers they had gained until they became a part of the unwritten constitution of the province. Scarcely a year

1 Public Records, Ms., XIX, 5, 297.

${ }^{2}$ Ibid., 299-318.

3 See Chapter II, The Legislature. 
passed that there was not a dispute of some kind over a money bill, and the lower house was almost invariably the victor. Some of the more important of these conflicts will be discussed, even at the risk of being tedious. Nothing, it seems to me, will illustrate better the gradual development of those principles of government for which South Carolina fought in the Revolution. "The spirit of 1776 " was not a sudden and unexpected product of ministerial tyranny. It was the spirit of 1719 , the spirit of 1750 , grown stronger and more determined, under the influence of forces, differing, perhaps in degree, but not in kind, from those in operation during the whole colonial period.

His Excellency arrived in Charleston, December 17, 1743 , and at once assumed the reins of government. ${ }^{1}$ By the first article of his instructions the following were named as councilors: William Bull, Alexander Skene, James Kinlock, Robert Wright, John Fenwicke, Joseph Wragg, Thomas Waring, John Hammerton, John Colleton, John Braithwaite, James Crokatt, and Edmund Atkin. In addition, the surveyor-general of the customs for the southern district of America was to sit in the council as a member extraordinary. ${ }^{2}$ Of these, all but the last four were named in Johnson's instructions. Judge Wright, however, had died of yellow fever in 1739 and Mr. Crokatt had removed to London. ${ }^{3}$

As usual the houses were soon involved in a dispute over money bills. The council passed the annual tax

1 Council Journals, IIs., XI, 1-2.

Ibid., 16-17; Public Records, Ms., XX, 66-6i.

ss. Car. Gazette, No. 279, June 9, 1739. 
bill on its first reading, on February 19, 1745, and sent down a message stating their objections to the clause which obliged all taxable persons to make return on oath of their money out at interest and of all cash in hand exceeding tro thousand pounds currency. ${ }^{1}$ The assembly entirely disregarded the message and again passed the bill in its original form. The council passed it a second time on May 17, and, in accordance with the rule of December 11, 1739, sent down a separate schedule of amendments. ${ }^{2}$ This was likewise disregarded and the bill put to its final passage in the assembly. It came up for its third reading in the council on May 23. A message was sent to the lower house complaining that no attention had been paid to their amendinents, suggested on the first and second readings, and again insisting that the oath clause should be omitted. The lower house still refused to make the change desired and the bill was rejected by the council. ${ }^{3}$ The assembly adjomrned on the 25th, but as their term was about to expire by law, they were soon after dissolved and a new election called.

The writs were made returnable on September 10, but the assembly was prorogued from time to time, and a quorum for business did not meet until December 4 . Among the members returned were Othniel Beale, Gabriel Manigault, Samuel Eveleigh, Robert Brewton, Elias Horry, Isaac Mazyck, Thomas Drayton, George Saxby, Andrew Rutledge, William Pinckney, and Stephen Bull. William Bull, Jr., was again elected

${ }^{1}$ Council Journals, Ms., XiII, 44-46.

2 Ibid., $216-217$.

${ }^{3}$ Ibid., $233-234, \mathbf{2 3 9}$. 
speaker. ${ }^{1}$ After a very brief session, an adjournment was taken to January $\overline{7}, 17+6^{2}$ The first business that came up was in regard to the tax bill. In the election just held the question of requiring persons to make oath as to the amount of money which they had on hand and out at interest may have been the principal issue. At all events, when the bill came before the assembly for its second reading on January 20 , a motion to insert the mooted clause was defeated by the vote of the speaker. ${ }^{3}$ This was a victory for the council. A few days later, the bill was sent down by the council with a schedule of seven proposed amendments. On examining the bill and finding that the council had not endorsed it as passing on its second reading, the assembly returned it for endorsement. The upper house became angry and declared that they should certainly have been given an answer to their message. However, for the sake of the public welfare, they agreed to pass the measure. It was finally enacted into a law on June 17, the council amendments being entirely disregarded."

Another feeble attempt of the council to interfere in a money bill, made in April, 1747, was equally futile. They informed the lower house by message that they had directed their committee on Indian affairs to join the house committee in a conference to consider the papers laid before them by the governor, adding that

${ }^{1}$ Com. House Journals, Ms., XXI, 1, 45.

2 Ibid., $7 \mathrm{I}$.

3 Ibid., 168-169.

4Ilid., 1S9-193, 200-201, 210-211; Statutes, III, 67S. 
they had obtained the estimates of expense and other papers and given them in charge to their committee. The assembly resolved "not to confer with the committee of the Upper House of Assembly on any estimate of expense whatever."'

The next move of the assembly was to deny the right of the council even to suggest amendments to a revenue measure. The rule adopted in 1739 allowed them to submit amendments on a separate schedule. Fourteen amendments to the annual tax bill were thus sent down to the lower house, June $2 \overline{7}, 17+8$. A motion to reject them as a whole failed, and three were accepted and incorporated in the bill. Two days later, the upper house complained because only three of their amendments had been accepted and urged the assembly to reconsider them. This was done and four more were agreed to. At the same time resolutions were passed to the effect that such compliance should not be drawn into precedent, and "that no agreement should at any time be made with the Council to countenance or warrant their sending any Schedule of Amendments at any time to the Tax Bill or Estimate or any Subsidy Bill.",

Governor Glen also became involved in the controversy and aroused the indignation of the assembly. A clause in the bill imposed a tax upon officer's' salaries and upon the governor's house rent. Glen, as the party most interested, sent a message of protest to the house on the 27 th. They resolved that he had greatly infringed their privileges in taking notice of a tax bill

${ }^{1}$ Com. House Joumals, Us.. XXII, 492-494.

2Ilid., XX111, 659-663, 67s-679, 691. 
or any other measure before it came up for his official consideration. He hastened to apologize for his inadvertency and harmony was again restored. ${ }^{1}$

The assembly were not satisfied with the sole power of framing the annual tax bill. Their control over revenue measures of all kinds was made an excuse for continued encroachments upon the governor and council. A dispute over the reorganization of the provincial navy resulted in the assertion of a very broad claim, which was, however, soon abandoned. The navy consisted of two small scout boats built to patrol the southern frontier and prevent the escape of runaway slaves to St. Augustine. These boats were out of service for some time, and the number of slave desertions had increased. The assembly resolved, on April 4,1749 , to defray the expenses of equipping the boats, and requested the governor to appoint the commanders and give directions for raising the men. Glen submitted their message to the council, and they sent for the commissary to make an estimate of the expense. They resolved that his estimate of $£ 4,000$ per annum was too great an outlay for the province to make, except on the most urgent necessity. On being informed of this, the assembly retorted that they regarded their house as the only proper judge of any expense necessary to be entered into. Glen succeeded in convincing them that a recognition of this claim would exclude the governor and council from any share in legislation, for they assured him that the claim had been made through inadvertence.

1 Com. House Journals, Is., XXII, 663, 700-701, 704-705. 
But at the same time, they adopted a resolution to the effect that they possessed all the porrers and privileges of the British House of Commons in regard to money bills, $^{1}$

Toward the close of this year (17 19$)$, there occurred another dispute, in the course of which the council defined their idea of a money bill. A bill to encourage the making of potash provided that a certain sum of money should be loaned to a Mr. Stephens for five years to purchase slaves. The council amended it by increasing the amount to be loaned. The assembly at once resolved that they had the sole right of granting all supplies and that no other legislative body had any right to increase or diminish any grant made by them whereby a tax or duty was to be imposed. ${ }^{2}$

In reply, the council denied the sole power of the lower house to grant money, but stated that they would waive all arguments on that point and show that the potash bill was not a money bill and would not be so considered by the House of Commons in Great Britain. Money bills were only those in which the following or similar words were used: "We His Majesty's dutiful and Loyal subjects, the Commons of England (or of Great Britain), in Parliament assembled, do cheerfully give and grant.', Bills in which this style was not used were never regarded as money bills. They cited a number of examples in support of their assertion, such as the act 2 George II, chapter 35, for granting a bounty on tar, pitcls, and turpentine. and the act 5

${ }^{1}$ Com. House Journals, Us.. XXIV, 78, 217, 259-260, 262-263, 425426. 429, 439-440.

2Ibid., XXV, 459, 462. 
George II, chapter 8, for encouraging Sir Thomas Lombe by paying him fourteen thousand pounds sterling. Among the colonial precedents were a bill for appointing Mrr. Fury agent of the province in Great Britain, 1747, and another for appointing Mr. Crokatt agent in 1749 . The potash bill was no more a money bill than either of these, and yet the council had amended both of them without complaint. ${ }^{1}$ The dispute was now brought to a close by the dropping of the bill, on the ground that the expense of the province in defending its frontiers was too great to make the appropriation. ${ }^{2}$

Although the council could neither initiate nor amend a money bill, the assembly apparently never denied them the right to reject a measure as a whole. It was a right which they frequently exercised. As they were quick to see and zealous to oppose any infringement upon the royal prerogative, it was rarely necessary for the governor to interpose his veto power. The only instance which I can find of the veto of a tax bill occurred in 1753. Governor Glen rejected the bill for the fiscal year 1752-1753, because it required the collectors of the tax to receive English and Spanish coins in payment at certain rates. He showed that this was inconsistent with the proclamation statute of the 6th of Anne. A midsummer session of the general assembly was called, and a new bill, without the objectionable clause, was passed and ratified on August $25 .^{3}$

The manner in which the assembly took advantage of their control over money bills to retain Mr. Crokatt

${ }^{1}$ Com. House Journals, Hs.. XXV, 54-549.

${ }^{2}$ Public Records, Ms., XXIV, 261-265.

${ }^{3}$ Com. Housc Journals, Ms., XXVIII, 569, 5i1-574, 593, 610. 
as colonial agent against the will of both governor and council has already been discussed.' This dispute, which lasted from July, 1753, to March, 1756, was the most serious that had occurred between the two houses since President Middleton's administration. During the course of it the commons adopted a resolution on March 21,1755 , that no account, petitions, or any other paper relating to a claim for public services should be sent to the council for their inspection. ${ }^{2}$

This resolution, which was made a standing rule of the house, was destined to give trouble after the agency dispute was settled. When the tax bill for 1756 came up for its second reading in the council on April 1, they asked the lower house to send up the accounts and rouchers upon which the estimate was based. A resolution to comply with the request was defeated, and attention was called to the resolution of March $21 .^{3}$ The council refused to proceed with the bill until they could see the vouchers. The assembly were equally stubborn. They informed Governor Glen that it would be useless for them to sit longer and asked leave to adjourn for a time. Another message, dated two days later, maintained that the council had no right to see the vouchers and accounts, even granting that they were an upper house, which could reasonably be denied until they were so constituted by act of parliament. Then they touched the governor on his most sensitive spot by taunting him with not presiding over

1 See Chapter IV, Colonial Agents, 165-168.

${ }^{2}$ Com. House Journals, Is., XXX, 40s-411.

3 Ibid., XXXI, 166-167. 
the council when it presumed to sit as a legislative body. In conclusion, they agreed to send up the desired papers, if any precedent could be found in the English parliament since $1688 .^{1}$

Glen replied by sending them his thirteenth instruction, which, like Nicholson's thirty-fifth, gave the council the same rights as the commons in regard to money bills. He stated, however, that he did not contend that the council had any right to see the vouchers and accounts. He only hoped that the house would send them up and break the deadlock, as it was only a trivial matter after all. Speaking of his relations to the council, he declared that he had the right under the constitution to be present at all their meetings whether executive or legislative, and that he had exercised that right whenever he found it necessary for the king's service. $^{2}$

As the council still retained the tax bill, an humble remonstrance was drawn up by the assembly and presented to Governor Glen on the 29th. The preparation of this document was an excellent bit of diplomacy. They flattered Glen with the assurance that no one in the province knew the British constitution better than he. To him, then, they appealed. If he thought that they had assumed any powers not exercised by the House of Commons in England, they begged that he would dissolve them. On the other hand, if the council had brought all the evils upon the province, they hoped that he would suspend those who had been

1 Com. House Joumals, .1s., XXYI, 183, 186.

${ }^{2}$ Ibid., 189-191. 
the occasion thereof and appoint other men who had the service of His Majesty and the welfare of the province more at heart. A day later, they resolved not to proceed upon any business whatsoever until the council made reparation for the injury done them in withholding the tax bill. ${ }^{1}$

Still smarting under his exclusion form the legislative council and captured by the flattery of the lower house, Glen called the assembly before him and made a long speech, in which he sided with them and censured the council. The behavior of the assembly was praiseworthy, as they had always voted ample supplies to His Majesty. The council were in the wrong in rejecting the tax bill of the previous year and in withholding the present bill. They should have waived their privileges and passed the act without seeing any accounts or rouchers, because of the necessity of procuring funds to complete the fortifications at Charleston and to erect a fort among the Cherokees. On the other hand, he must assert the council's right to reject bills, though if any of them wantonly exercised that right he would suspend them. He did not think that there were sufficient grounds for doing so now. ${ }^{2}$

The lower house still refused to proceed on any business until the council made amends. On their request, His Excellency permitted an adjournment from May 4 until the second Tuesday in October. Before that day came, Governor Glen's long administration was closed by the arrival in the province of his successor, William Henry Lyttleton.

1 Com. House Joumals, 3s., XXXI, I99-202, 205.

2 Ibid., 205-20s. 
Lyttleton reached Charleston, June 1, 1756, and was received with the usual pomp. A proclamation was issued to continue all officials in office and the general assembly was called together on the 17 th. $^{1} \quad \mathrm{~A}$ tax bill was at once passed, but when it came up for a second reading in the council they demanded to see the accounts and vouchers. The assembly replied that to send them up would be contrary to a standing order of their house from which they could not recede. A deadlock was again threatened, when the council, acting under the advice of Lyttleton, gave up their contention and passed the bill. They sent down a separate schedule of amendments, however, which the lower house refused to read. The council had made up their mind to yield, so they passed the measure on its final reading, July 2. ${ }^{2}$ The representatives of the people thus won another victory.

This controversy gave rise to considerable theorizing on the subject of political philosophy, not only in the messages of the houses, but also in the public prints. In the Gazette for May 13 there was an article signed $\mathrm{T}-\ldots \mathrm{s} \mathrm{W}-\ldots-\mathrm{t}$, which questioned the right of the council to sit as an upper house. ${ }^{3}$ In the very nature of things, he declared, the same body could not be both an upper house of the legislature and an advisory council. After they had passed upon a measure as a branch

1 Council Journals, Ms., XXV, 259-273.

2 Com. House Journals, Is., XXXI, 220-221, 223-224, 230; Public Records Ifs., XXVII, 124-125.

s. Car. Gazette, No. 1142, May 13, 1756. MeCrady states that this was probably written by Thomas Wright, son of the former chief justice. S. Car. under Royal Govt., 285. 
of the legislature, what necessity would there be for the governor to ask their advice as a council? They affected to resemble the House of Lords in England, though there was a rast difference in their positions. The Lords of Parliament were summoned by writ and had no vote in electing members of the commons. They were the hereditary councilors of the king and could not be displaced at the pleasure of a minister. The members of the council in South Carolina were dependent and held their places during pleasure. They roted for members of the assembly and thus had their representatives. "Can they represent themselves and be represented? It appears to me rery odd that any set of men can be so deluded as to imagine that one day they can be freemen, roting for representatives; the next day representing themselves as peers; and the third day metamorphosed into a council of state to approve or disapprove of what they had determined the morning or day before as an upper house."

An upper house, he continued, could not be created by the king's instructions, but only by act of parliament or by act of the provincial assembly. Beginning with this attack on the royal instructions, he went on to declare that the were binding only on the governor and council, for they alone conld be remored for disobedience. Ther could not be binding on the people, for, if they were. all laws might be made and all taxes levied by instructions, and there would be no need for assemblies. Certainly, many of the instructions had never been executed, merely becanse the people had not thought proper to pass laws for that purpose. 
Eren if the council were admitted to be an upper house, they could have no right to meddle in money matters, as would appear from precedents in the House of Commons. It was foolish for them to demand to see the accounts when they had no power to lessen or angment a single item in the estimate. In concluding, he defied the council to show any anthority from the king to act as an upper house.

Governor Lyttleton's administration extended from June, 1756, to April, 1760. During these years of warfare, a spirit of harmony pervaded the government. The journals are filled with accounts of Indian affairs and of discussions in regard to the ways and means of aiding the northern colonies. An incident which happened just after Lyttleton's departure will serve to show how completely the assembly had gained control over money bills. On the third reading of the tax bill, July 18, 1760, one small amendment was suggested by the council. The lower house refused to read the bill, but returned it at once with a rerbal message to the effect that they looked upon the conduct of the council in proposing an amendment to a money bill as a violation of their privileges and calculated to destroy the harmony that should prevail between council and assembly. In reply, the council maintained their right to amend, but said that, out of regard for the public welfare, they would waive their rights and pass the bill as it was. ${ }^{1}$

We are ready now to summarize the struggle over revenue measures and consider its influence upon the

${ }^{3}$ Com. House Journals, IIs., XXXIII, 34•, 360. 
constitutional history of South Carolina before 1760 . When the royal government went into operation in 1721 the council and assembly had practically an equal control over money bills. All public accounts were passed upon by a joint committee from the two houses, and the council frequently exercised the right of amendment. The first ten years of the royal period were taken up with the efforts of the planters to increase the amount of irredeemable paper currency. The assembly, representing the planter interest, was brought into conflict with a council composed largely of merchants. The result was the development of a bitterness between the houses which time could not eradicate.

As early as 1725 the assembly asserted that ther possessed all the powers and privileges of the British House of Commons and denied the right of the council to amend money bills. The denial was put in still stronger language in the Pinckney resolutions of 1735. In 1737 the assembly made two distinct encroachments: they refused to permit the council to examine public accounts, and they appointed a committee of their house to sit with the governor and council during the recess of the legislature and join with them in signing warrants on the public treasurer and regulating the details of an Indian campaign, a purely administrative function. As the result of a dispute in 1739, the council were permitted to suggest amendments in a separate schedule. They were regularly disregarded, however, and finally, in 1748 , the assembly denied them eren this privilege. ${ }^{1}$ The long dispute over the continuation of

1 The council continued the custom of sending down amendments, however, for several years, but they were always treated with contempt. 
Mr. Crokatt as agent resulted in the resolution of March 21,1755 , that no account, petition, or any other paper relating to a claim for public services should be sent to the council for their inspection.

During all these disputes the assembly were continually using the control over money bills to extend their power in other directions. Thus they elected a public treasurer and an agent who were obnoxious to the governor and council, withlyeld the salaries of executive and judicial officials, and occasionally appointed committees to attend to purely executive business. 


\section{CHAPTER VII}

The Downfall of Royal Government (1760-1776)

THe year 1760 marks the beginning of an epoch in the history of Great Britain and her colonies. The accession of George III and the downfall of French rule in America are important events in the constitutional development of South Carolina. Before that date the struggle between the popular and prerogative elements was local in character. It was primarily a conflict between two parties within the province itself. The conservatives, representing the merchants and traders of Charleston, controlled the council. Not being dependent upon the assembly for a living, ${ }^{1}$ they were even more zealous than the governor to defend the interests of the crown. They failed because they were far less numerous than the planter faction and because the home government did not afford them the proper degree of sympathy and support.

Shortly after 1760 , an entire change came about. The victories over France in India and America resulted in the growth of a strong sentiment of imperialism in Great Britain. Coincident with this was the accession of a sovereign who was determined to uphold the royal prerogative throughout the limits of the British dominions. The American colonists soon felt the

I The members of neither house received pay for their services. 
effects of the change. The colonial administrative srstem was strengthened, and schemes were proposed for an imperial army and an imperial system of taxation. The Americans might naturally have expected some srmpathy from England, for they and the masses of the English people stood for exactly the same principle, the principle of popular government. But the English common people were not sufficiently well represented in parliament to make themselves felt, and if they had been, they were too thoroughly saturated with imperialism to sympathize with the colonists.

The time selected for putting the new system of imperial control into operation was not propitious. The withdrawal of the French from Canada and Louisiana and of the Spanish from Florida, by removing a constant source of danger, necessarily made the Americans less dependent on the mother country. Not only this, but the several intercolonial wars had brought the colonists into closer relations with one another and taught them the advantages of union.

Another mistake which the British government made in South Carolina was their failure to give due encouragement to the loyal party within the colony. A native could scarcely hope to be governor or chief justice of the province. The council was so degraded by the appointment of English office-holders that the South Carolina gentleman scorned to accept a position which he would once have sought with eagerness. This shortsighted policy of the home government accounts largely for the weakness of the loralists. It affected more particularly the wealthiest and most influential 
merchants and importers, the men who would naturally have led the prerogative party. Many others were infiuenced by commercial boycotts and the use of phrsical force by the patriots.

In previous chapters the attempt has been made to trace the encroachment of the popular upon the prerogative element in the govermment. By 1760 the share of the council in legislation had become rery small. They rarely initiated or amended a bill of any kind, never a rerenue measure. The annual estimate of expenses was made up entirely by the assembly, no vouchers, bills, or other public claims being submitted to the council at all. At times, an appropriation would be made without stating for what particular service. The council could not strike out the item and could not ask why it was inserted. Their only remedy was to reject the entire bill. If they did this, the placemen among them would suffer from the delay in the payment of their salaries and fees, the merchants from the injury to the public credit. Occasionally a measure of general legislation would be rejected, but the assembly could usually force the council to terms by withholding the tax bill.

Public officials chosen nominally by the general assembly were, as a matter of fact, merely the nominees of the lower house. This is shown conclusively by the election of Public Treasurer Motte in $17+3$ and br the continued emplorment of $\mathrm{Mr}$. Crokatt as agent after 1753. The first of these rictories made it possible, a few years later, for the assembly to order money paid out of the treasury without the consent of the governor 
and council; the second enabled them to represent their conduct to the home government in the most favorable light.

The encroachments on the judiciary were less pronounced. According to the theory held by the British ministry, the establishment of courts of justice was distinctly a prerogative of the crown. Still it was necessary to have the co-operation of the colonial legislature. Thus, in 1732, the attempt to create a court of exchequer was frustrated by the refusal of the assembly to pass a jury law.

It is essential to an independent judiciary that the judge should be assured that he will not be removed nor his salary reduced or withheld for his official acts. In those countries in which the distinction between state and government is fully worked out these questions are settled by a written constitution. In the absence of such a document the judges are dependent ultimately upon either the executive or the legislature. The struggle between king and parliament for the control of the judiciary is one of the chief features of English history in the seventeenth century. The solution reached in the Act of Settlement was not extended to the colonies, so the conflict continued there until the downfall of British rule. In South Carolina the greater part of the judicial business was in the hands of the chief justice until 1766. The crown appointed and removed him at will. After 1760, he mas almost invariably a needy placeman sent out from England. The attempts of the assembly to extend their influence along the other line suggested was in the end equally 
futile. At the beginning of the royal period, the chief justice, like the governor, was paid out of the colonial treasury. The assembly, as we have seen, withheld Judge Wright's salary for several years and finally allowed him only a part of what was due. As a result, the home government, in 1735, fixed upon him a permanent salary payable out of the quit rents. The higher judiciary thus became entirely free from popular control. The unsuccessful attempt made in the circuit court acts of 1768 and 1769 to secure an independent judiciary has been discussed. Not only did the judges still hold at the pleasure of the crown, but the colony had to settle permanent salaries upon them. ${ }^{1}$

The weakness of the executive is well portrayed in the correspondence of Governor Glen with the home government. In a letter to the Duke of Bedford, dated October $10,17+8$, he said that the province would be more prosperous if its constitution were newly modelled or newly promulgated, "for by a long loose administration it seems to be quite forgotten, and the whole frame of government unhinged, the political balance in which consists the Strength and Beauty of the British Constitution being here entirely overturned, and all the Weights that should trim and poise it, being by different laws thrown into the Scale of the People." He then went on to give a few instances. Almost all places of honor or profit in the province were disposed of by the general assembly, which, in practice, meant the lower house. Thus they appointed the treasurer, the commissary, the Indian commissioner, the controller

I See Chapter III, The Judiciary. 
of the duties, the powder receiver, and various other executive officials.

"I must further observe to Your Grace that much of the executive part of Government and of the Administration is by various laws lodged in different sets of Commissioners, thus we have Commissioners of the Market, of the Workhouse, of the Pilots, of the Fortifications, and so on without number. Nor have they stopped at Civil Posts only, but all Ecclesiastical Preferments are in the disposal or election of the People, though by the King's Instructions to his Governor the Power of collating to all Livings of which His Majesty is Patron, is vested in him."

All of these officers and most of the commissioners were named by the general assembly and were accountable to them only. "Let their neglects or mismanagements be ever so flagrant, a governor has no power either to reprove or remove them. Thus little by little the people have got the whole administration in their hands."

This state of affairs, he continued, had been brought about largely by the mistakes of former governors. For example, a message from one of his predecessors read: "Myself and His Majesty's Council are informed that Fort Johnson is in a ruinous condition, we therefore desire that you may give directions to repair it." This was not a request for the means to carry on the work, but an invitation to the house to take charge of the administrative details.

He was of opinion that many of these evils might be corrected if the councilors would only support the governor and attend council more regularly. Instead of being a source of strength, they had really weakened 
his position in excluding him from participation in their legislative business and in trying to create a collegiate executive by interpreting the phrase governor in council to mean governor and council. ${ }^{1}$

In another letter, the governor gave a specific example to illustrate the weakness of his position. He discovered that one of the Indian traders was furnishing the captain of the French fort at the Alabamas with supplies, which he in turn utilized to further French interests among the Indians. Such conduct was very detrimental to the public welfare and should have been severely punished. Glen contented himself, however, with merely requesting the commissioner for Indian trade not to renew the man's license. Receiving an evasive answer, he wrote a formal letter to the commissioner prohibiting him in His Majesty's name from granting the license. Nevertheless, the license was issued and the governor was powerless to prevent it. ${ }^{2}$

Such in brief was the political condition of South Carolina when the British government began to strengthen its system of imperial control. For the first few years after the province was settled in 1670 all powers, legislative, executive, and judicial were vested in the governor and council. Since then the assembly had gradually made encroachments until it had become practically the sovereign power. The demands of the British government after 1760 were not especially unreasonable or tyrannical, but they were made upon a people who had too long been accustomed to having their own way.

1 Public Records, Ms., XXIII, 232-245.

2 Ibid., 218-220. 
A letter from the Board of Trade, dated November 14, 1759, notified Governor Lyttleton of his transfer to the Jamaica government and of Thomas Pownall's appointment to succeed him in Carolina. William Bull, who had been commissioned lieutenant-governor, was to administer the government until Pownall arrived. ${ }^{1}$ Bull, who was son of the former lieutenant-governor, had for many years been speaker of the assembly and, since 1749 , a member of His Majesty's council. During the remaining sixteen years of the royal period, he was called upon five different times to assume the burdens of government, and altogether presided over the province for more than eight years. He was a man of great tact and ability and was thoroughly respected by all. Born and reared in the province, he understood and appreciated the prejndices of the people, but was at the same time intensely loyal to the mother country. McCrady is of the opinion that South Carolina would not have joined the other colonies in the Revolution, had the British ministry adopted the principle of home rule, given Bull a full governor's commission, and filled the places of honor and trust with the educated young men of the province instead of with needy placemen and strangers from England. ${ }^{2}$

Pownall decided not to come out to the province, and Thomas Boone, governor of New Jersey, was transferred to South Carolina. Bull's first administration began with Lyttleton's departure in April, 1760, and continued until Boone's arrival in December of the fol-

1 Public Records, M/s., XXVIII, 268-269.

2 S. Car. under Royal Govt., 795-796.

22 
lowing year. ${ }^{\prime} \quad$ Most of this period was taken up with providing for expeditions against the Cherokees, led by Colonels Montgomery and Grant. ${ }^{2}$ A new assembly, called to meet October 6, 1760, was dissolved by the death of George II, and another met March 26, 1761. Benjamin Smith was again elected speaker.

In the summer of 1761 the old dispute over money bills was renewed. The council sent down a bill, on June 13, for laying an additional duty on negroes, which they had amended in some minor details. The assembly at once replied that this was a moner bill and the council had no right to amend it. Because of the necessity for securing a war revenue, however, they had simply struck out the amendments and repassed the measure. The council were warned that if they ever attempted to amend a money bill again the assembly would refuse to proceed on any business until satisfaction was made them. The council now rejected the measure and informed the house that they had the right to amend any and all money bills, and proposed to exercise the right whenever they saw fit. The only response to this was a resolution of the assembly not to proceed on any further business with the council during that session. Lieutenant-Governor Bull interfered at this juncture and prorogued them for a few days to allow their wrath to abate. ${ }^{*}$

1 Public Records, Ms., XX1X, 54-55, 210.

2 For accounts of these expeditions, see Hewatt, His. of S. Car., Chap. X, McCrady, S. Car., under Royal Govt., Chap. XIX.

${ }^{3}$ Com. House Journals, Is., XXXIII, Part II, 4, 5, XXXIV, $2,3$.

4 Ibid., XXXIV, 152-153, 194, 197. 
On re-assembling, the lower house passed another duty bill, which was likewise rejected by the council. The assembly now adopted a device occasionally used by the English House of Commons. A bill to continue the Soutl Carolina regiment in service was passed with a rider attached containing the provisions of the duty act. At the request of Lieutenant-Governor Bull, the council passed the measure on its second reading and sent down a schedule of two amendments, one of which provided for a change in the title to show that a duty was imposed on imported negroes. As the assembly refused to adopt the amendment, the bill was rejected by the council on its third reading. In a long message to the lieutenant-governor, the lower house declared that they had done all they could to provide for the regiment, but that all their efforts had been frustrated by a council which at no time during the session had over five members present. The houses were now adjourned until autumn. ${ }^{1}$

Governor Boone arrived in the province December $22,1761 .^{2}$ On the 26th, he dissolved the assembly because they had been elected under the election law of April, 1759, since repealed in England. ${ }^{3}$ Writs were at once issued for a new assembly to meet on February 6, 1762. Benjamin Smith was again chosen speaker without opposition. ${ }^{4}$ The first session came to an end by prorogation on May 29. On the last day of

1 Com. House Journals, IIs., XXXIII, 220, 222, 224, 228, 230-235.

- Public Records, Extra, Ms., III, 437.

${ }^{3}$ Com. House Journals, $\mathrm{H}$ s., XXXIV, 274-275.

+Itid., XXXV, Part I, 3. 
the session, a committee was appointed by the lower house to sit with the governor and council during the recess for the purpose of distributing presents among the Indians. Governor Boone assured them that he could look upon such a committee only as private gentlemen and would not consult them in regard to executive business. ${ }^{1}$

The second session of Boone's first general assembly continued from June 29 to July 9. Leave was then asked to adjourn for a time. His Excellency informed them that it would be more conformable to the best examples for him to prorogue them. Accordingly, they were prorogued, first to August 9, and later to September 9.2

The last session of this assembly continued only five days, but during that time there began the most serious dispute that had yet arisen between the representatives of the people and the servants of the crown. On March 19, 1762, Governor Boone sent a message to the assembly complaining of the election act of 1721 on the ground that it was too loose and general and too little obligatory on the church wardens. They replied very briefly that they had never known or heard of any bad consequences arising from the said law and could see no necessity for altering it. ${ }^{3}$

If Boone had possessed any wisdom or tact, he would have dropped the question at once. Instead of doing so, however, he proceeded to wait for a concrete instance

1 Com. House Journals, Ms., XXXV, 135, 137.

${ }^{2}$ Ibid., 145, 152-153.

3 Ibid., 41, 49. 
to demonstrate his charges, or rather, being an obstinate prerogative official of the Edward Randolph type, for an opportunity to show his power. His patience was soon rewarded. The law provided that the church wardens, after receiving the writs, should take oath before a magistrate to perform their duties, give proper notice, hold the election, and then make written returns of the results on the writs. Some special elections to fill racancies. were held during the recess from July 9 to September 9. In looking over the results it was found that the writ for the parish of St. Paul's was blank. On September 13 the assembly resolved that the writ should be given back to the church wardens to make a return. While the question was under discussion, a message was received from the governor stating that he was in the council chamber ready to receive the assembly for the purpose of ratifying a certain bill that was before him. Mr. Lowndes and Mr. Pinckney were sent up to inform His Excellency that the house was in a debate and desired his indulgence for a short time. A further investigation showed still another defect in the election. The church wardens had not taken the necessary oaths before a justice of the peace before opening the polls. The house decided, however, to overlook this flaw and recognize the validity of the election. ${ }^{1}$

The return, as finally made out by the wardens, showed that Christopher Gadsden had been elected. The ordinary oath as a member of the assembly was taken, and then Mr. Bee and Mr. Sommers accompanied

I Com. House Journals, Us., XXXV, 154, 156-157. 
him into the presence of the governor to see the state oaths administered. They soon returned with the announcement that His Excellency desired the immediate attendance of the house in the council chamber, where he would assign reasons for refusing to qualify Gadsden. They went up at once and were entertained by the governor with a very haughty speech. On receiving their request for an extension of time before coming to the council chamber, he had consulted their journals to see what particular business they were engaged in. $\mathrm{He}$ was astonished, he declared, to find that they were endeavoring to dispense with an act of the assembly to which they owed their very existence as a legislative body. The writ, as first presented to himself and council, contained no return at all, and, in addition to this, the church wardens confessed that they had not been sworn according to law. His conclusion would have done justice to a Stuart monarch: "To manifest in as public a manner as I can my disavowal of so undeniable an infraction of the Election Act, I do hereby dissolve this present General Assembly and it is dissolved accordingly.",

Writs were at once issued for the election of a new assembly to meet on the 25th of October. Gadsden, Lowndes, Bee, and in fact nearly all of the members of the previous house were returned. Benjamin Smith was again the choice for speaker. The state oaths were duly administered to the members, Gadsden among the rest. On the 26 th, the assembly was prorogued to Norember 2.2."

1 Com. House Journals, 11s., XXXV, 15s-159.

${ }^{2}$ Ibid., NXXY, Part II, 1-3. 
Governor Boone tried in vain to distract the attention of the assembly from their grievances with eloquent descriptions of the British victories in Canada. On November 24, Messrs. Rutledge, Lowndes, Manigault, Gadsden, Pinckney, Scott, Wragg, Ferguson, and Doctor Oliphant were appointed a committee on privileges and elections, and ordered to consider the proceedings of September 13 in connection with the liberties and privileges of the house to determine their own elections. ${ }^{1}$

On November 30, Mr. John Rutledge, chairman of the committee, presented a long report, together with a series of resolutions. The report argued that the election law did not require the wardens to take a special oath before each election, and maintained that Gadsden's election was regular and valid. Taking up. Boone's statement that the assembly owed its existence to the said election act, they declared that the right of the people to be represented in the legislature was not founded upon any statute, but was derived from the known and ancient constitution of the mother country. The resolutions declared that the commons house of assembly were the sole judges of the election of their members, that the governor could not constitutionally take notice of anthing said or done in the assembly until it came before him in the regular manner, that his refusal to administer the oaths to Gadsden was a breach of the privileges of the house, and finally that the dissolution of the late assembly for matters cognizable only by them was a violation of the freedom

1 Com. House Journals, .Hs., XXXV, Part II, 12. 
of elections and tended to destroy the liberties of the people. ${ }^{1}$

The report and resolutions were adopted and sent to the governor. In his reply Boone strove in vain to keep down his anger and speak in terms of politeness. $\mathrm{He}$ maintained that the election act very plainly required the wardens to take a special oath before each election and said that the general oath of office was not sufficient. He denied that the assembly had an inherent right to examine and finally determine an election in violation of the law. No branch of the legislature, he declared, had any power to dispense with a law of the land. Taking up the resolution about dissolving the assembly, he informed them that he would exercise the power of dissolution whenever he saw fit, whether his reasons were satisfactory to the assembly or not. ${ }^{2}$

A message in answer to this was prepared by Gadsden limself as a member of the committee on privileges and elections. The election was discussed in detail, and a strong effort was made to show that it was both regular and legal. The original return had been made on a separate slip of paper instead of on the writ itself. One of the wardens twice asked the council clerk for the writ in order to make the proper return, but he said that the separate return would be sufficient. The message then went on to assert that the right of representation did not rest upon the election act, but was a part of the British constitution. Repeal all the elec-

${ }_{1}$ Com. House Journals, Ms., XXXV, Part II, 18-20, 26-28.

Ibid., 35-37. 
tion laws that had ever been passed and there would still remain the charter from Charles II, which guaranteed a share in the government to the freemen. But the charter itself did not confer a privilege; it simply confirmed the natural right of the freemen to be represented. ${ }^{1}$

Boone retorted that they might send him forty such messages if they wished, but he could assure them that they would have no effect. On December 16, the assembly resolved by a vote of twenty-four to six that they would enter on no further business until the governor did justice to them. The committee of correspondence was ordered to draw up a full account of the dispute and transmit the same along with the proper vouchers to the agent in Great Britain. ${ }^{2}$

On the 28th, Governor Boone adjourned the assembly to January 24, 1763. A quorum for business did not appear and the few members present adjourned from day to day until March 24. Four days later the governor again adjourned them to April 6. The same performance was repeated and it was not until September 2 that a quorum was secured. Benjamin Smith having left the province, the Honorable Rawlins Lowndes was unanimously chosen speaker. ${ }^{3}$

${ }^{1}$ Com. House Journals, Us., XXXV, Part II, 38-45. This is one of the very few instances during the royal period in which an appeal was made to the charter. Here it was only to confirm what was called a natural and inherent right. That it should be referred to at all is good evidence that the colonies were drawing together and that the influence of New England was making itself felt. The charter had in reality been suspended by act of parliament in 1729 .

${ }^{2}$ Ibid., 46, 48-49. There is a printed pamphlet in the library of the New York Historical Society which contains all of these papers.

3 Ibid., XXXVI, 1-13. 
The old dispute was soon renewed. At a special election, Sir John Colleton was returned as a member for the parish of St. John's, Berkeley county. On September 5, the assembly ordered Mr. Gadsden and Mr. Moultrie to attend Sir John and see him take the state oaths before the governor. Boone was not in the council chamber at the time, and they went to his residence. He promptly ordered Gadsden and Moultrie out of the house, but requested Sir John to stay and receive the oaths. ${ }^{1}$

The news of this insult was not calculated to improve the temper of the assembly. A message from the governor urging the immediate passage of a tax bill was laid on the table, and the house busied itself with a committee report on a petition to the king for Boone's removal. The feeling was still further intensified, on September 12, by Boone's refusal to administer the state oaths to several members, for the alleged reason that he wished first to look over the assembly journals and see that they had qualified as members. The assembly resolved that this was a new insult and breach of privilege. ${ }^{2}$

The members, for the most part, now retired to their several homes, and the meetings of the assembly came to an end. An incursion of the Creek Indians into the northwestern settlements resulted in a short session early in January. A motion to discharge the resolution of December 16, 1762, to do no further business

${ }^{1}$ Com. House Joumals, Ms., XXXVI, 17-18.

2 Ibid., 28-29. 
failed to carry.' Most of the members now absented themselves from the house, and public affairs were neglected until after the departure of Governor Boone for England, on May 11, 1764. ${ }^{2}$

The troubles of the province did not yet cease entirely. Lieutenant-Governor Bull again took charge of the government and issued a proclamation for the general assembly to convene on May 22. One of the first questions to come up was in regard to a tax bill for the years 1762 and 1763 . In the original estimate, the sum of seven thousand pounds currency was inserted for Governor Boone, but the item was struck out by the assembly on the third reading. The council remonstrated and finally rejected the entire bill. Mr. Gadsden, from the committee appointed to consider the matter, declared that the bill's rejection must give a great shock to the public credit, putting it on a "most disadvantageous and scandalous footing, because the Suppliers of the Public must thence clearly perceive that their hopes of payment do not so much depend on the Faith and Honor of their natural Representatives as upon the Caprice and Pleasure of the Council, and very often even of a majority of such as are altogether placemen, and have no Natural Tie or Connection whatever with the Province." 3

The general assembly was prorogued from August 25 to September 18. On re-assembling, the council gare

1 Com. House Joumals, IIs, XXYVI, Part II, j̄-6.

2 Public Records, Js., XXX, 143.

${ }^{3}$ Com. House Journals, Ms., XXXYI, Part II, 236, 244, 250-251. Many such references might be cited to show the decline in the influence of the council. 
up their contention and the supply bill was passed without any provision being made for the gorernor. ${ }^{1}$

Meanwhile, the whole affair had been laid before the home government. Two questions had to be considered, one in regard to the governor's salary and the other in regard to the method of administering the state oaths. The first was settled by an additional instruction to Lord Charles Greville Montagu, Boone's successor as governor. He was to recommend to the assembly the necessity of providing for the arrears of Boone's salary during the two and a half years of his administration. Any delay in paying it would be a dangerous precedent, as it would prevent governors from faithfully executing their duties and make them dependent on the legislature. ${ }^{2}$ Montagu arrived in the prorince June $12,1766,{ }^{3}$ and, on the 17 th sent this instruction to the assembly. It was referred to a committee, which made its report through Mr. Lynch on the 20th. The report declared that the house had done right in withholding the governor's salary, but that, out of regard for the instructions of His Majesty, who had been graciously pleased to remove Boone, they would rote him his allowance up to the time of his departure. Thus they would show to the world that they did not intend to oppose His Majesty or overawe his governor, but merely desired to protect their own rights and privileges. The assembly were so elated over the recent repeal of the Stamp Act that

${ }^{1}$ Com. House Journals, .Us., XXXVI, Part II, 266-268.

${ }_{2}$ Public Records, Ifs., XXXI, 30-31.

${ }^{3}$ Ibid., 72 . 
they adopted this report and provided for Boone in the tax bill.'

The other problem, in regard to the method of administering the state oaths, was solved by the Board of Trade. In a report of July 16, 1764, they reprimanded Boone for presuming to be the sole judge of elections, and, to prevent such disputes for the future, recommended that instructions be sent to Lieutenant-Governor Bull authorizing him to appoint deputies to administer the oaths. ${ }^{2}$ The assembly, however, were very well satisfied with the existing arrangement so long as Bull was in the executive chair. Finally, on July 11. 1769, they reminded Governor Montagu of the report and requested him to abide by it. He replied by sending down a commission to Peter Manigault, Rawlins Lowndes, James Parsons, Charles Pinckney, Benjamin Dart, and William Noultrie, all members of the commons house. ${ }^{3}$

During the two years from Boone's departure in May, 1764, to Montagu's arrival in June, 1766, Lieutenant-Governor Bull was for the second time at the head of affairs. The principal event of the period was of course the struggle over the Stamp Act. The act was passed early in 1765, but was not to go into effect until November 1 . As soon as the news of its passage reached the colonies, there was great excitement and indignation. As might have been expected, the New England colonies took the lead in formulating

1 Com. House Journals, Hs., XXXTII, 160-161, 165-166, 194.

2 Public Records, Ms., XXX, 172-175.

${ }^{3}$ Com. House Joumals, Us., XXXYIII, 43, 51-52. 
measures of opposition. The Massachusetts House of Representatives proposed, June 6, that representatives from the lower houses of the various colonies should meet in New York on the first Tuesday in October.' The proposition came before the South Carolina assembly, July 19, and a committee was appointed to consider the matter. Chairman Gadsden reported on the 26th that the measure proposed was both prudent and necessary and recommended the appointment of a committee to proceed to New York. The report was adopted by the house. A few days later, they resolved to defray the expenses of a committee of three, and ordered the public treasurer to advance to them a sum not exceeding six hundred pounds sterling. Thomas Lynch, Christopher Gadsden, and John Rutledge were appointed. ${ }^{2}$

The house adjourned on August 9 until September 9 , but, as their three years' term was about to expire, they were dissolved and a new assembly was called to meet on October 28. In addition to Pinckney, Rutledge, Laurens, Lowndes, Lynch, Gadsden, and others already mentioned, we find one new member who was to take a leading part in the subsequent history of the province. This was William Henry Drayton, elected from the pariwh of St. Andrew's. The Honorable Peter Manigault was unanimously chosen speaker."

1 Barry, Hist. of Mass., Second Period, 294-295.

${ }_{2}$ Com. House Journals, Hs., XXXVII, 89-90, 94, 97. The custom had gradually grown up for the treasurer to pay out money on the sole order of the lower house. This gave considerable trouble a few years later, as we shall see.

I Ibid., XXXVII, Part 1I, 1-4. 
The delegates to the Stamp Act Congress returned to Charleston late in November, and, on the 26th, Gadsden presented their report to the assembly. The declaration of rights, the petitions to the king and Commons, and the memorial to the Lords were all reported and entered in the journals. ${ }^{1}$ Gadsden, Wright, Pinckney, Parsons, and Rutledge were appointed a committee to draw up suitable resolutions. On the 29th, they reported a series of eighteen resolutions, which were in practically the same language as the declarations of the Stamp Act Congress. After adopting these, the house adjourned to January $7,1766 .^{2}$

As the day approached on which the law was to go into force, the popular leaders made every effort to arouse the people to opposition. A letter from Lieutenant-Governor Bull to the Board of Trade affords good evidence of the powerful influence of New England on the other colonies. He declared that the people were generally disposed to obey the law, "but by the artifices of some busy spirits the minds of men here were so universally poisoned with the principles which were imbibed and propagated from Boston and Rhode Island (from which Towns, at this time of the year, vessels very frequently arrive) that after their example the People of this Town resolved to seize and destroy the Stamp Papers, and to take every means of deterring the Stamp Officers from performing their duty.",3

1 Com. House Joumals, Ms., XXXVII, Part II, 15-24.

I Ibid., 26-29, 32.

${ }^{3}$ Letter from Lieutenant-Governor Bull to the Board of Trade, dated November 3, 1765. Public Records, Ms., XXX, 281-289. The following account is taken largely from this letter. 
When the ship bearing the stamped paper arrived in the harbor on October 18, a mob of excited men gathered with the intention of destroying the paper whenever an attempt was made to land it. Seeing the danger, Bull ordered it to be sent down to Fort Johnson, and reinforced the garrison there with a sergeant and twelve Royal American troops. When the mob found that the paper was out of their reach, they directed their fury against the stamp officers, Mr. George Saxby, inspector, and Mr. Caleb Lloyd, distributor of stamps. Saxby had not yet returned from a visit to England, but his house was attacked and badly damaged.

The commotion now subsided to some extent until the arrival of Saxby on the 27th. Hearing of the feeling against him, he prudently decided not to come up to Charleston, but to get off the boat at Fort Johnson, where Lloyd had also retired for safety. Two days later they both signed an agreement to suspend the duties of their offices until parliament could take action upon the united remonstrance of the colonies. ${ }^{1}$

Business soon eame almost to a standstill. The law courts were closed, land grants could not be passed, ships remained in the harbor as if under an embargo, and no transaction requiring the use of stamps was carried on. ${ }^{2}$ Late in January, or early in February, of 1766, Colonel Peter Randolph, surveyor-general of His Majesty's customs, arrived from Virginia. He said that he had advised the customs officers in his district

1 Public Records, Ms., XXX, 279-280.

2 Ibid., 299. 
to clear vessels without the use of stamped paper when the stamp officials refused to act, and that this was the practice in all the colonies of his district to the northward. The people now began to murmur against the embargo, which they had borne with patience for thirteen weeks. The harbor was filled with ships, which were allowed to come in, but not to depart. Various applications were made to Bull, both by the people and by the assembly, urging him to open the port. $\mathrm{He}$ finally agreed to issue certificates to ship captains stating that the stamp officer's refused to act and that no paper was to be had. A small sum was charged for this service, probably equivalent in value to the stamps which the law required to be affixed to the ordinary clearance. After this arrangement had been made, Colonel Randolph ordered the collector and naval officer to clear vessels as usual. ${ }^{1}$

Popular clamor next demanded that the courts should be opened. When the Stamp Act went into effect, the common law courts consisted of Chief Justice Charles Skinner $^{2}$ and an assistant justice, Mr. Robert Pringle, who rarely attended and never took any active part in the work of the court. Skinner expressed the opinion that no business could be done except upon stamped paper, and he adhered to it in spite of the appeals of the Charleston bar. The lawyers then requested Lieutenant-Governor Bull to appoint three new assistant judges. He agreed, and commissions were issued to

${ }^{1}$ Public Records, Hs.. XXXI, 22-25. See Wallace, Constitutional History of S. Car., 38-39.

2 The name is usually so spelled in the public records and in the legislative journals, although the form Shinner is sometimes found.

23 
Rawlins Lowndes, on February 27, to Benjamin Smith, on February 28, and to Daniel Doyley, on March 1. ${ }^{1}$ The chief justice lived some distance back in the country, and these appointments were made without his knowledge. When the court met on March 3 , he was much surprised at the presence of his new colleagues and perceived at once that they had been put on the bench for the purpose of overruling his decisions.

The case of Jordan vs. Law came up and motion was made by Mr. Bee, attorney for the plaintiff, that judgment should be entered. Messrs. Mauigault, Pinckney, Parsons and Rutledge argued in favor of the motion. Egerton Leigh, His Majesty's attorney-general, opposed it on the ground that no stamped paper was to be had. A petition from some of the merchants, traders, and other inhabitants of the province urging the court to proceed without stamped paper was presented by Mr. Parsons. The consideration of the whole matter was postponed until the next return day, which was April 1. Then the case again came up and the assistant judges expressed the nnanimous opinion that judgment should be entered for the plaintiff in the usual manner, since stamped paper could not be obtained. The chief justice said in dissent "that the comrt ought not to open nor business to go on, until the act of Parliament imposing stamp duties in His Majesty's American Dominions could be complied with."'

The plan to open the comrts has thus about to succeed, when it met with opposition from an unexpected

1 Public Records, Ms., XXXI, 99, 215-216. 
quarter. Dougal Campbell, clerk of the court, refused to enter up the judgment, on the ground that the use of unstamped paper was contrary to law. The assistant justices appealed to Lieutenant-Governor Bull to suspend him for refusing to obey their orders. Their representation, together with a petition from Campbell, was laid before the council. Campbell maintained that, as the Stamp Act provided for heavy penalties in case of the disobedience of those who held offices similar to his own, he was bound to regard himself as an accountable agent and not a mere ministerial officer. Bull and the council decided that he was conscientious in his conduct and was not guilty of wanton disobedience or contempt. Accordingly, they refused to suspend him.

This scheme having failed of its purpose, other similar expedients were tried, but all were foiled by the vigilance of Judge Skinner and Mr. Campbell. On May 3, a ship arrived from Barbadoes with unofficial news that the Stamp Act had been repealed. There was great rejoicing in Charleston, and the chief justice, very much against his will, was forced to participate in the revels. Lientenant-Governor Bull at cnce opened the courts of chancery and ordinary, and clerk Campbell announced his readiness to proceed with unstamped paper in the common law courts. Skinner, however, remained firm in his resolution to take no part in the work of the court until official information was received of the repeal of the law. He kept the court seal in his hands, but the assistant judges opened the courts and made use of Mr. Pringle's seal at arms.

The judges now proceeded to take revenge on the 
clerk. He was sererely reprimanded for refusing to enter the judgment in Jordan $r^{\circ}$. Lax and was ordered to pay a fine of one hundred pounds proclamation money within ten dars. Bull suspended the payment of the fine until His Majesty's pleasure could be signified. When the court met on May 29, Campbell's ardor for the roval prerogative had reir much cooled, and he presented a petition setting forth his sorrow at having incurred the court's displeasure, and begging to hare his fine remitted. They decided that his conduct had proceeded from an error of judgment rather than from contempt for the comrt, and the fine was reduced to ten pounds.

Official information of the repeal of the Stamp Act was received on June 5. Judge Skinner at once announced to the court, through the clerk, that he was read! to proceed to business. The assistant justices refused to allow his notice to be entered on the records. ${ }^{1}$

The sequel of this story is found in the suspension of Skinner from office in the following year. On April 18, the assembly requested Gorernor Montagn to suspend him, at the same time sending up a long series of charges, the substance of which was ignorance of the law and general misconduct in office. The charges were sent to Skinner with the request that he should answer them as soon as convenient. A memorial in

1 The foregoing account is based upon "An Account of the proceedings of the Chief Justice. Assistant Judges, and Lawyers of South Carolina on the Stamp Act." and other documents enclosed in a letter from Governor Montagu to the Board of Trade. Public Rccords, $\mathbb{1 1}$ s, XXXI, 86-230. 
reply was received from him on May 3. The council took his case under consideration and expressed the unanimous opinion that he was unacquainted with the law and unfit for the office of chief justice. Accordingly, on May 11, Governor Montagu suspended him until the king's pleasure could be known. Skinner seems to have been a rough uncouth sort of character, although his memorial and his report on the Stamp Act controversy show that he was a man of education, and, though not a lawrer, possessed of considerable legal knowledge. ${ }^{1}$ Possibly he was correct in his statement that the real reason for the attack upon him was because he did his duty in endeavoring to execute a law of parliament. Speaking of the committee which made the charges, he declared that all of them were "furious Liberty Boys, three of them the rery three who were appointed to meet the famous Congress at New York, the chairman one of these three." Gadsden was the chairman. ${ }^{2}$

As we have already seen, the new governor, Lord Charles Greville Montagu, arrived in Charleston on June 12, 1766. The people were still rejoicing over the repeal of the Stamp Act, and the feeling of loyalty was strong. There were a few bold spirits, howerer, led by Christopher Gadsden and William Jolmson, an intelligent artisan, who were not entirely satisfied. The

$1 \mathrm{McCrady}$ is of the opinion that some one else prepared these papers for him. S. Car. under Royal Govt., $46 \pi$.

2 Public Records, Ms., XXXI, 326-392; Com. House Jonmals, Ms., XXYVII, 351-359, 391-392. The unanimous vote of the council in favor of suspension indicates that there was at least some foundation for the charge-. 
Declaratory Act meant more to them than the repeal of the Stamp Act. Their fear's were realized when parliament passed a statute the next year for levying a duty on glass, red lead, white lead, painter's colors, tea, and paper imported into the province.

Montagu's first administration extended from 1766 to 1769 , with the exception of a few months in the summer of 1768 , which he spent in the northern colonies. Lientenant-Governor Bull had charge of the government in his absence. During these three years there were two disputes with the assembly: one was over the furnishing of supplies to the British troops in Charleston; the second grew out of the efforts of the assembly to join other colonial assemblies in opposing the Townshend Acts.

In the summer of 1769 , Governor Montagu received a formal letter from Major Chisolme, commanding the royal troops in Charleston, in which complaint was made of the scarcity of fuel and other barrack necessaries. His Excellency laid this letter before the assembly, together with a message urging that the supplies be furnished. 'They wished to know whether the troops were to be used for garrison duty on the frontiers, as the independent companies and several detachments of royal troops had previously been employed. In reply, the governor enclosed a copy of a letter which he had received from General Gage, dated New York, October 8, 1768. The letter stated that there would be a greater number of troops assembled at St. Angustine than could be lodged

${ }^{1}$ statutes at Large, 7 George III., chap. 46. 
there during the winter, and asked the governor to provide accommodations at Charleston until spring for such as Brigadier-General Haldimand could not put under cover at St. Augustine. Accordingly, His Majesty's twenty-first regiment and one company of royal artillery had been lodged in the barracks at Charleston and were still there, though spring had come and gone. ${ }^{1}$

The assembly seems to have ignored the matter entirely, for, on July 27, Governor Montagu called attention to his previous message on the subject and urged them to provide at once the needed supplies. ${ }^{2}$ A committee to whom the message was referred expressed the opinion that no provision should be made for the troops because they were not to be used to garrison the frontier, and because they should be supported out of the revenue raised in the colonies by act of Parliament for that purpose. ${ }^{3}$ On September 6, the troops were embarked for St. Augustine. ${ }^{4}$

Just as in the Stamp Act controversy, the province of Massachusetts Bay led in the opposition to the Townshend Acts. Their House of Representatives sent a circular letter, dated February 11, 1768, to the assemblies of all the colonies. In this document they acknowledged the supreme legislative power of parliament over the empire, but declared that they derived all their powers from the constitution and could not

${ }^{1}$ Com. House Journals, Ms., XXXVIII, 19-20, 22-23, 25-27; Public Records, Ms., XXXII, 100.

${ }^{2}$ Com. House Journals, Ms., XXXVII1, 84-85.

3 Ibid., 136-137.

1 Public Rccorls, Ms., XXXII, 101. 
overleap it without destroying their own foundation. They furtler pronounced it as "an essential unalterable Right in nature grafted into the British Constitution as a Fundamental Law, ever held sacred and irrevocable by the subjects within the Realm, that what a man hath honestly acquired is absolutely his own, which he may freely give, but cannot be taken from him without his consent." The letter then went on to say that the duty acts recently passed by parliament were for the express purpose of raising a revenue and hence were infringements on the natural and constitutional rights of the American subjects, who were not and could not be represented in parliament. Various other grievances were also enumerated: the king appointed colonial governors and fixed a stipend for them without the consent of the people and at their expense; judges held commissions at the pleasure of the crown and were entirely independent of the people; complaint was made of the mutiny and desertion act and of the powers conferred upon the commissioners of the customs in America. ${ }^{1}$

On receipt of this letter, the Virginia House of Burgesses drew up appropriate resolutions, and, on May 9 , sent out a circular letter of similar import. Among other things, they declared that "no power on earth has a right to impose Taxes on the People, or to take the smallest portion of their Property without their Consent given by their Representatives in Parliament.', In conclusion, the hope was expressed that a union of

${ }^{1}$ Com. House Journals, Ms., XXXYII, Part III, 9-12. See Bancroft, Hist. of the United States, Edition 187s, 1T, 73-74; Palfrey, Hist of New England, V, 378-3is. 
all the colonies would again establish the constitution on genuine principles. ${ }^{1}$

Both of these letters were received by Speaker Manigault during a recess of the assembly. On July 10, he wrote a letter to the Honorable Thomas Cushing, speaker of the Massachusetts House of Representatives, informing him that South Carolina had already instructed her agent in England to join with the agents of the other colonies in obtaining a repeal of the recent acts of parliament and to assist them in all matters where the general interests of America were concerned. The term of the present assembly was about to expire and they would soon be dissolved. Consequently, he would not have the opportunity of laying the Massachusetts letter before them. ${ }^{2}$

The assembly was dissolved on September 8 and writs were issued for a new election, returnable on October 25. On the 24th, they were prorogued by LientenantGovernor Bull to November 15 in order to await the return of Lord Montagu, who was spending the summer in the northern colonies. ${ }^{3}$ The governor arrived in Charleston on the 30 th. ${ }^{*}$ The assembly met on the day appointed, and the Honorable Peter Manigault was again unanimously chosen speaker. ${ }^{5}$ This body, according to Bull, had so imbibed the political principles of Boston that it was filled with a "kind of enthusiasm very

\footnotetext{
1 Com. House Journals, IIs., XXXVII, Part III, 12-15.

2 Ibid., 15-16.

${ }^{3}$ Ibid., 1.

${ }^{4}$ Public Records, Ms., XXXII, 60.

5 Con. House Journals, Ms., XXXII, Part III, 2-4.
} 
apt to predominate in popular assemblies and whose loud cries silence the weaker voice of moderation.", Weekly advices from Boston kept them informed in regard to the Liberty fiasco, the anti-rescinding resolutions and other matters transpiring in New England. During Lord Montagu's absence from the province a letter was received from the Earl of Hillsborough calling his attention to the Massachusetts circular of February 11 and telling him to use his best efforts to induce the South Carolina assembly to disregard it. ${ }^{2}$ Consequently, in his opening speech on November 17, the governor asked the commons to discountenance and treat with contempt any letter or paper that might appear to have the smallest tendency to sedition or to inflame the minds of the people against the authority of parliament. ${ }^{3}$ On the very next day, the forbidden letter of February 11 and also the Virginia letter of May 9 were laid before the house by Speaker Manigault. They were read and referred to a committee consisting of Messrs. Parsons, Gadsden, Laurens, Pinckney, Rutledge, Lloyd, Elliot, Lynch, and Dart. ${ }^{*}$ With the addition of Lynch and Dart, this was the same committee that had been appointed to draw up an address in answer to the governor's opening speech. They were now added to the latter committee, making the

1 Bull to the Earl of Hillsborough, October 18, 1768, Public Records, Ms., XXXII, 56-57.

2Ibid., 36, 56; Com. House Journals, Ms., XXXVII, Part III, 21. A special secretaryship of state for the colonies was ereated in 1768 and the Earl of Hillsborough was the first secretary.

s'om. House Journals, IIs., XXXVII, Part 1II, 6.

I Ibid., 9-16. 
personnel of the two exactly the same. Both committees reported on the 19th. First, a humble address to His Excellency stated that no letter or paper of a seditious character had yet come before the house, and, if such should come, that they would treat it with the contempt which it deserved. ${ }^{1}$

The door's of the house were then locked, and the other committee reported a series of resolutions to the effect that the letters under consideration were "replete with duty and loyalty to His Majesty, respect for the Parliament of Great Britain, sincere affection for our Mother Country, tender care for the preservation of the rights of all His Majesty's Subjects, and founded upon undeniable Constitutional Principles;' that a humble and loyal address should be presented to His Majesty imploring him to relieve his American subjects from their grievances; and that the speaker should be directed to send these resolutions to the speakers of the Massachusetts and Virginia assemblies and assure them that their measures had met with the entire approbation of the commons of South Carolina. ${ }^{2}$

The doors were thrown open again and the whole house waited on the governor to present their address. In reply, he informed them that His Majesty regarded the Massachusetts circular of February 11 as a seditious document, and he gave them warning to disregard it or take the consequences of their folly. ${ }^{3}$

The assembly returned to their own chamber and barely had time to pass the following order when they

1 Com. House Journals, I/s., XXXVII, Part III, 17-19.

2 Ibid., 19-20; Public Records, IIs., XXXII, 61-64.

3 Com. House Journals, Hs., XXVII, Part III, 21. 
were dissolved by the governor: "Ordered, That His Excellency's speech to His Majesty's Council and this House with the address of this House to His Excellency, and His Excellency's answer thereto, and also the letter from the Honorable Thomas Cushing, Esquire, Speaker of the late House of Representatives of the Province of Massachusetts Bay, and the Letter from the Honorable Peyton Randolph, Esquire, Speaker of the House of Burgesses of Virginia, addressed to the Speaker of the late House of Assembly of this Province, and laid by him before this House with the resolutions of this House thereupon, and all other matters relating thereto be printed and made public.",

Governor Montagu became very angry and declared to the Earl of Hillsborough that he would not call a new assembly until he received special instructions from His Majesty to do so. ${ }^{2}$ Nevertheless, writs were issued February 8, returnable on Narch 21. His Excellency did not permit the house to meet, however, but prorogued them from time to time until the middle of June. Then instructions were received from the Earl of Hillsborough authorizing the issue of election writs, ${ }^{3}$ and the houses were called together on the 15th. No quorum appeared and they were adjourned to June 26. All the old leader's were returned and Peter Manigault was again chosen speaker without opposition. ${ }^{4}$

Governor Montagu, in his opening speech on the 27th, declared that His Majesty did not wish the province

wom. House Joumals. Hs.. XXVII. Part III, 2l-?2.

2 Public Records, Hs., XXX11, 73.

stid., 75.

4om. Hous .Jommals, Hs., XXXV11I, 1-10. 
to suffer any longer because of the intemperate resolutions of the late assembly, and had, accordingly, authorized the summoning of a new assembly. Calling attention to the deplorable condition of the back country, he informed the house of the objections made by the Board of Trade to the circuit court act of 1768 and urged them to consider the matter again. ${ }^{1}$

Two committees were at once appointed by the house, one on grievances and the other to prepare an answer to the governor's speech. The former reported on the 28 th that it was a grievance that the assembly had been adjourned from April 12 to September 6, 1768, that the next house, which met on November 15, was dissolved four days later, and that the present house was prevented by divers prorogations from sitting until June 15 , in direct violation of the election law of 1721 , which required sittings of the assembly at least once in every six months. To the great grievance of the province, the assembly had been in session only five days in fourteen months. The house agreed to the report and adopted resolutions in accordance therewith. ${ }^{2}$ Two days later the other committee made its report, and a humble address was drawn up and sent to the governor. The house expressed sorrow that their necessary and constitutional resolutions had given so much offense

1 Com. IIouse Joumals, IS., XXXVIII, 11. The back comtry had been settled very rapidly and was entirely without courts of justice. The act of 1768 provided for circuit courts, but it was disallowed in England. Another act passed in the following year received the king's approval and was put into force in 1772 . This question is considered more in detail in the chapter on the judiciary. See 133-141.

2Ibid., 17-19. 
as to cause a discontinuance of the meetings of the assembly beyond the period allowed by law. They were willing to believe that he meant no infringement on their rights and privileges, but hoped that this would not be made a precedent. In conclusion ther declared their readiness to do all in their power for the relief of the settlers in the back country and to attend to the other matters suggested by His Excellencr. The governor simply returned thanks for the address and assured the house that he had never intended to infringe any of the rights of the people, especially when they had the sanction of a law. ${ }^{1}$

The assembly now proceeded to business. The dispute with the gorernor over the question of furnishing supplies to British troops has already been discussed. It aroused more or less ill feeling, but did not prevent the passage of a new circuit court act.

His Excellency, Lord Charles Greville Montagu, set sail for England on July 31, 1769,2 and for the fourth time the burdens of government fell upon William Bull. During the two years of his administration the spirit of rebellion and along with it the desire for union spread rapidly throughout the colonies. On December 15, 1768, the House of Lords adopted a series of eight resolutions condemning the recent proceedings of the people of Massachusetts Bay, and prepared an address to the ling praving that persons accused of treason in the colonies should be brought to England for trial, according to the statute 35 Henry VIII, chap. 2. The

1 Com. House Journals, Ms., XXXVIII, 20-21, 23.

2 Public Records, Ms., XXXII, 91. 
House of Commons agreed to both the resolutions and the address, and the king expressed his approval early in February, 1769. ${ }^{1}$

The Virginia House of Burgesses was the first to utter a protest. They adopted a series of resolutions, on May 16, and directed their speaker to send copies of them to the speakers of the various assemblies throughout the continent and to request their concurrence therein. They resolved that the sole right of imposing taxes on the inhabitants of Virginia was legally and constitutionally vested in the House of Burgesses; that it was the undoubted privilege of the people of Virginia to petition their sovereign for a redress of grievances, and lawful and expedient for them to procure the concurrence of His Majesty's other colonies in praying the royal interposition in favor of the violated rights of America; and finally, that all persons accused of treason or any other crime committed m the colony should be tried by a jury of their neighbors and not transported beyond the seas. ${ }^{2}$

These resolutions had barely been adopted when the Burgesses were dissolved by the governor. Speaker Randolph carried out the order of the house, however, and sent copies of the resolutions to the various colonial assemblies. They were read before the South Carolina assembly, on Angust 17, and entered upon the jcurnals. Two days later, when thirty-seven of the

1 Cobbett, Parlinmentary History, XVI, 476-480, 494-51I; Lecky, England in the Eighteenth Century. III. 363-364.

${ }^{2}$ Com. House Jourmals, Is., XXXVill. 16j-166. See Bancroft, Hist. of the United States, Edition 187s, 15, 158-160. 
forty-one qualified members were present, the house manimously adopted the resolutions, with the necessary changes in phraseology, and with the addition of one to the effect that the statute 35 Henry VIII, chap. 2, could not extend to the colonies, where there was sufficient provision made by the laws of the land for the trial of persons accused of treason. ${ }^{1}$

Four days later, the assembly was prorogued to November 7. In a letter to the Earl of Hillsborough, Bull excused himself for not putting an immediate stop to their proceedings by dissolution. "Experience," said he, "had shown that a repetition of such marks of displeasure had not produced any good effects of changing men or measures in the present universal jealousies of the people, but had tended rather to furnish the more turbulent and factious with popular arguments to keep up their clamors and feed their discontent.', 2

On November 7 , the assembly was further prorogued to the 28th. Meanwhile, the colony was very much agitated over the non-importation agreement. An agreement was drawn up, on June 28, binding the signers to encourage and promote the use of American manufactures in general and those of South Carolina in particular. They were not to import any goods from Great Britain, except negro cloth, powder, lead, nails, and a few other necessaries. Finally, they looked apon every inhabitant who refused to sign this agreement within one month as an enemy to the true interests of the colony, and pledged themselves neither to

1 Com. House Journals, Ms., XXXVIII, 174-176.

2 Pubtic Records, .1/s., XXXII, 95. 
purchase from nor sell to such person any goods or merchandise whatever.' A new form of agreement, slightly changed, was adopted at a mass meeting on July 22. These were to remain in force until the objectionable acts of parliament were repealed. Many signatures were obtained, some voluntarily, others through the fear of social and business ostracism. Considerable excitement and ill feeling were aroused. The principal opponents of the measure, William Wragg and William Henry Drayton, expressed their views at great length in the Gazette. Christopher Gadsden and others replied in defense of it. ${ }^{2}$

The assembly met promptly on November 28 . Some ordinary business was disposed of, and an adjournment was taken from December 8 to January 9 . Just before adjourning, the house adopted the following order and resolution:

"Ordercd, That the Public Treasurer do advance the sum of ten thousand five hundred Pounds Currency out of any money in the Treasury, to be paid into the Hands of MIr. Speaker, Mr. Gadsden, Mr. Rutledge, Mr. Parsons, MIr. Ferguson, Mrr. Dart, and Mrr. Lynch, who are to remit the same to Great Britain, for the support of the just and Constitutional Rights and Liberties of the People of Great Britain and America.

"Resolved, That this House will make provision to reimburse the Public Treasurer the said sum.,"

1'ublic liccords, Hs., XXXII, 81-83.

2 An interesting account of this controversy will be found in MeCrady, S. Car. under Royal Gort., 644-658.

3 Com. House Journals, ils., XXXVIII, 215.

24 
With this money, bills of exchange for fifteen hundred pounds sterling were purchased and sent to England at the first opportunity. In a letter to the Earl of Hillsborough, under date of December 12, Lientenant-Governor Bull stated that it was probably to be used for the support of the Bill of Rights Society in London, which was collecting funds to pay the debts of the notorious John Wilkes. Bull then went on to explain how it was that money could be drawn from the treasury without the governor's consent. It was, he declared, merely a part of a general movement toward democracy. Since the first establishment of the colony the people had been gradually acquiring greater and greater control over the government. The king himself was chiefly responsible for this, for, in his desire to encourage the settlement of the province, he had been too generous in granting civil and religious indulgences. At first, when emergencies had to be met, the practice was for the governor, council, and assembly to concur in an order to the treasurer to advance the amount of money desired, and then to resolve that provision for repayment would be made in the next annual tax bill. The second step was for the lower house alone to resolve in regard to the reimbursement of the treasurer. Then, as their control over money bills became more extensive, it was but natural that they alone should pass the original order on the treasurer. The only control now left to the council was the power to oppose the tax bill which provided for the repayment of the amount advanced. They did this on several occasions, says 
Bull, but in the end were always compelled to yield. ${ }^{1}$

In this particular case the commons house attempted to follow the method of procedure just described. The schedule of the next annual tax bill contained an item providing for the repayment to Treasurer Jacob Motte of the money advanced by him under the resolution of December 8 . The council returned the bill and schedule, on April 5, 1770, expressed surprise at the item in question, and declared that they would never give their sanction to a measure which contained a provision tacitly affronting His Majesty's govermment. Further, they denied the right of the assembly to issue money out of the treasury without the governor's consent or for any other than local or provincial purposes. In conclusion, they stated that they would not pass the bill and trust to the lieutenant-governor to reject it, lest he should, like a former governor, construe their concurrence as advice from his council to assent to it. ${ }^{2}$

The commons referred this message to a committee, which reported a long series of resolutions on the 10th. Among other things, they denied the charge that they could appropriate money only for local purposes, and declared that they had always exercised the undisputed right of borrowing money out of the treasury. Finally, they took up the most vulnerable paragraph of the council's message, namely, that which related to a former governor's taking the concurrence of the legislative council as their advice to pass a bill. Such language, they said, simply served to prove the duplicity

1 Public Recorels, Ms., XXXI1, 132-133.

${ }^{2}$ Com. House Joumals, Ms., XXXVIII. 38i-385. 
of those members who could, as an upper house, pass a bill which they intended, as a privy council, to adrise the governor to reject-conduct which could not fail to prove to His Majesty the absurdity and inconsistency of their acting in that double capacity, and, they hoped, would induce him to grant the province an upper house distinct from the privy council and composed of independent men of property. ${ }^{1}$

On the following day, before the house had time to consider these resolutions, they were adjourned to June 5. Aside from one day sessions on June 5 and July 23, the recess was continued to August $14 .^{2}$

Meanwhile the whole matter was under consideration in England. Lord Hillsborough laid the case, with all the papers relating to it, before William de Grey, the attorney-general. De Grey made his report on February 13, 1770. Beginning with the first charter to the proprietors, he gave a brief history of the province with special reference to the disputes over moner bills. He assumed that the constitution of the province was to be found in the governor's commission and instructions, which allowed both houses the sole control over money bills. After this brief historical summary, he proceeded to deliver his opinion on the points at issue. In the first place, he declared that the house of assembly of South Carolina could not legally order the payment of money out of the public treasury without the concurrence of governor and council. Such a power could not be warranted by the modern practice of a few years,

1 Com. House Journals, Hs., XXXVIII, 389-392.

${ }^{2}$ I bid., 392-397. 
irregularly introduced and improvidently acquiesced in. Secondly, the order of December $S$ was also illegal, because the money adranced was not to be applied to the particular service of the province. In the third place, the order of payment being thus illegal, the payment itself was illegal, but he did not think it just to hold the treasurer liable, after the frequent acquiescence in similar orders. In conclusion, he said that preventive measures should be taken for the future, but whether this should be done by act of parliament or by instructions to the governor he left to the wisdom of His Majesty's servants. ${ }^{1}$

This report came before the privy council and it was decided that an additional instruction to the governor should settle the matter. The instruction, dated April 1t, 1770, forbade the governor, under penalty of removal from office, to give his assent to any bill appropriating money for other than provincial purposes, except on a special requisition from the king. The governor was also instructed to see that in money bills for the future a clause was inserted subjecting the public treasurer to a treble penalty and loss of office for paring out any money except by a special order contained in some act or ordinance of the general assembly. ${ }^{2}$

It remained now to be seen how the assembly would receive this unequirocal expression of the royal will. Lieutenant-Governor Bull laid a cops of the instruction before them on August 16, and it was referred to

${ }^{1}$ I'ublic liccords. Hs., XXXII, 166-1S1. The last part of this report containing the opinion is given in Chalmers, Colonial opinions, 296-295.

a Putlic Records, $1 /$ s., XXXII, 236-210. 
a committee. ${ }^{1}$ The resolutions, reported and adopted on the 29th, contain the boldest declaration of rights that the South Carolinians had ret put forth. First, they resolved that the assembly had a right to grant money, with or without a requisition from His Majesty, for any purposes whatsoever, whenever they thought it expedient for the public service. It was further resolved that they had a right to order the public treasurer to advance money on a resolution of their house to repay it-a right which they had often exercised, and which the present lieutenant-governor and his predecessors had acquiesced in; that their resolution of December 8 was not unconstitutional, but strictly in accordance with the usage and practice of their house; and that they would not insert the required clauses relating to the treasurer in any tax bill. Perhaps the committee had by this time become startled at their own boldness. At any rate, in the final resolution they linted that they were not denying the powers of the king, but were simply resisting the unjust pretensions of his ministers. Thus, they resolved, "That it is the opinion of this Committee that a Minister's dictating how a Money Bill shall be framed is an Infringement of the Privileges of this House, to whom alone it belongs to Originate and prepare the same for the concurrence and assent of the Governor and Council without any alteration or amendment whatsoever.",2

The difficulty was soon complicated still further by the death of Jacob Motte, the provincial treasurer.

${ }^{1}$ Com. House Journals, Hs., XXXVIII, 403-405.

atid., 430-433. 
The assembly at once passed a bill for appointing his successor, which was amended in the council along the lines of the additional instruction. The lower bouse struck out the amendments, and the bill was rejected by the council on September 7 . At the same time another tax bill was rejected because it contained the objectionable clause for repaying the treasurer the ten thousand five hundred pounds advanced to the Wilkes fund. On the request of the assembly for leave to adjourn, Lieutenant-Governor Bull prorogued them from September 8 to January 16, 1771. ${ }^{1}$

In reply to the lientenant-governor's opening speech of January 16, the assembly said that they had done all they could to sustain the public credit, but that the council had rejected every tax bill sent to them. Taking up the additional instruction of April 14, they declared it to be both unnecessary and unconstitutional. Ministers were fallible as well as other men and often made errors. Instructions had been sent to several of the American governors, "which were diametrically opposite to Reason, Law, and the Constitution of the Colonies they were sent to, and which consequently were not carried into execution.'",

The sentence just quoted suggests a consideration of two conflicting theories in regard to the colonial constitution. From the standpoint of the king and ministry the constitution of the province was a written one, consisting of the commissions and instructions to the governors. Furthermore, they were strict construc-

${ }^{1}$ Com. House Journals, Hs., XXXVill, 453-456.

2 Ilid., $464-465$. 
tionists. If they wished a change they could easily make it; the colonists had no recourse but to acquiesce. The people of the colony, on the other hand, while admitting that the instructions expressed the will of the home government, maintained that the power of the government itself was limited. There were certain rights and privileges which were the heritage of Englishmen, wherever ther might fix their home. One of these rights, which they were determined to maintain in the face of all the instructions ever devised, was the right to tax themselves through their own representatives for whatever purposes they saw fit. A claim of the assembly, once recognized by the governor and council, was to them a part of the constitution-a more important part indeed than the instructions to the governor, for such precedents were often directly contrary to the instructions. They were loose constructionists. So far as they observed the commissions and instructions at all, they interpreted them in a very liberal manner. An example of this has already been noticed in connection with Governor Nicholson's thirtyfifth instruction. He was forbidden to allow the assembly any power or privilege not allowed by the king to the House of Commons in England. The interpretation placed upon this was that the assembly possessed all the powers and privileges of the House of Commons, including the sole power of framing and amending money bills.

In the corporate colonies of New England the reverse was true. The home govermment, in moments of thoughtlessness, granted powers and privileges, 
which they would afterwards have been glad to revoke. The colonists, however, cherished their charter constitutions and resisted erery attempt to weaken them through a loose interpretation. New England was thus the champion of strict construction, while the provinces, mostly in the south, were loose constructionists. ${ }^{1}$

The dispute over the additional instruction continued to occupy public attention to the exclusion of all business. The assembly adopted an ingenious scheme to entrap Lientenant-Governor Bull into giving up the point at issue. Thus, on January 31, they ordered the acting public treasurer ${ }^{2}$ to pay into his hands the sum of seren pounds currency per head to aid the poor Irish Protestants who had recently arrived. He refused the bait, howerer, and stated that he would accept the money only when it was roted by an ordinance of the general assembly. ${ }^{3}$

The next more made by the assembly affords an interesting example of their skill in interpreting instructions. They even went so far as to intimate that they would agree to the additional instruction if their interpretation was accepted. In a message of February 27 ,

1 A few words should be said in qualification of this statement. The New England colonies did oceasionally adopt a policy of loose construction when they felt that it would serve their end and would escape the attention of the English government. The most familiar example of this was of course the use made by Massachusetts of a trading compans's charter as the constitution of a colony.

2 Henry Peronneau, who had been assistant treasurer under Colonel Notte. BF an act of February 23. 17il. he and Benjamin Dart were elected joint treasurers. Com. House Journals, Us.. XXXVIII, 491: statutes, IV. 326-327.

3 Com. House Jumrnals. Hs.. XXXVIII, $474,476$. 
they pointed out a distinction between those funds in the treasury which could be granted by them alone and those which could be granted only with the joint consent of governor, council, and assembly. The receipts for each year's tax usually exceeded the amount appropriated to His Majesty for that year. Thus there would be a surplus in the treasury which had not been granted specifically to the king. This was the people's money and the assembly as their representatives had the sole right to dispose of it. They could vote to use it for the next year's expenses and thus reduce the taxes, or they could, by a resolution of their house alone, advance it for some particular purposes. The governors had never objected to this, but had often encouraged it by message. On the other hand, there were frequently large sums lying in particular funds, ${ }^{1}$ which the house had good reason to believe would not be called for before they could be replaced. Such money having been solemnly appropriated, no longer belonged to the people, hence the assembly would always ask the concurrence of the governor and council in resolutions to borrow it, and provision was always made for repayment. The order in favor of the poor Protestants was of the former character, to be paid out of the unappropriated surplus in the treasurer's hands. The additional instruction, so they argued, was intended to cover the other case only, where the money had already been appropriated to some other purpose. ${ }^{2}$

I An example of such a fund was the fortification fund, formed by the annual appropriation of five thousana pounds currency out of the proceeds of the general duty act.

${ }^{2}$ Com. House.Journals, iss., XXXVIII, 497-499. 
His Honor was not convinced by such reasoning and the controversy was continued. The assembly adjourned on March 20, and a quorum for business did not come together again until after Lord Montagu's return to the province. He arrived in Charleston on September 16, and the general assembly met one day later. The lower house at once proceeded to pass a tax bill for the years 1769 and 1770 . One clause in the estimate was for $₫ 28,123: 14: 8$ to the estate of Jacob Motte, to reimburse him for the money advanced for the bounty to Irish Protestants, for the survey of the province, for encouraging the culture of silk, and for other services. The phrase for other services, as was well known, included the $£ 10,500$ advanced to the Wilkes fund. On November 4, the council returned the bill, with their objections to that article, and stated that they were forbidden by instruction from passing any tax act which did not contain a clause inflicting treble penalty and forfeiture of office on the public treasurer for paying out money other than by an express order contained in some act or ordinance of the general assembly. To this the house replied that they would never regard any ministerial instruction in framing a money bill nor alter any part of the estimate on the requisition of the council. ${ }^{2}$

The dissolution of the assembly was brought about by the following bold move on their part: An order was passed, on October 2, requiring Henry Peronneau and Benjamin Dart, joint public treasurers, "to advance to the Commissioner's appointed on the Silk

\footnotetext{
1 Com. House Journals, Us., XXXYII, 57--5is.
} 
Manufacture a sum not exceeding Three Thousand Pounds Currency, to enable them to purchase with ready Money, raw Silk of the produce of this Province, to be transported to Great Britain for sale." The commissioners applied for three hundred pounds, as part of this order, but the treasurers refused to advance it. Complaint was made to the assembly, and they summoned Peronnean and Dart before them to show cause why they had not paid the order. The treasurers replied that they were afraid to advance the money in the face of His Majesty's additional instruction and a positive order from the governor and council. They were then asked, once for all, if they would make the payment, and, on giving a negative answer, were ordered to withdraw. The assembly immediately resolved that they had violated and treated with contempt the authority and privileges of their house and that they should be committed to prison in the common gaol at Charleston. A warrant was then issued and signed by Speaker Manigault, requiring the messenger of the house to arrest Peronneau and Dart and convey them to gaol. At the same time, the provost marshal or keeper of the gaol was ordered to take them into custody. Governor Montagu put a stop to these proceedings by an immediate dissolution. ${ }^{1}$

Late in February of the following year, writs were issued for a new assembly to meet on April $2 .{ }^{2}$ In the meantime, Lord Montagu had applied to the home government for advice. A letter from the Earl of Hills-

\footnotetext{
${ }^{1}$ Com. House Joumals, Ms., XXXYIII, 543, 579-584.

${ }^{2}$ Council Journals, Ms., XXXVI, Part II, 56.
} 
borough, under date of January 11, 1772, assured him that the king approved of his conduct in dissolving the late assembly and wished him to adhere to the additional instruction of April 14, 1770, and to put a stop by dissolution or prorogation to any further attempt of the assembly to carry into effect their unconstitutional claim of the right to dispose of public money without the consent of governor and council. Further, he was to inform the assembly that if they persisted in their attempts to violate the constitution, he would again dissolve them. ${ }^{1}$

Accordingly, when the assembly met on April 2, His Excellency acquainted them of the king's disapprobation of the conduct of the previous assembly and of his instructions to dissolve them in case they should follow a similar course. The commons refused to do business under such restrictions, so the governor issued a proclamation of dissolution on the 10th. ${ }^{2}$

Lord Montagu now adopted a plan of campaign by which he felt sure that he could bring the assembly to terms. An election was ordered to be held for an assembly to meet at Beaufort, Port Royal, on October 8. The reasons for this move were outlined in a letter to Lord Hillsborough. The leaders of the opposition lived in Charleston. They had already resolved to pass no tax bill that contained the treasurer clause of the additional instruction, or that did not contain the ten thousand five hundred pounds item. Many of these men would

${ }^{3}$ Public Records, Ms., XXXIII, 107-108.

${ }^{2}$ Ibid., 140, 142. The journals for this short session are lost; the account given above is taken from letters in the Public liecords. 
be prevented by their private affairs from attending at Beaufort, especially if the assembly was not allowed to sit at once, but was continued by short and frequent prorogations. Furthermore, the people of Beaufort were ready to support the royal interests in the hope of having the seat of government permanently located in their town. In the absence of the violent party, the conservative members living in and around Beaufort could be induced to pass a tax bill and attend to other business. Then, too, the Charleston interest might be brought to terms for fear of losing the seat of government. ${ }^{1}$

A few days after the writs were issued, Montagu's plans were changed by the receipt of a letter from Lord Hillsborough, stating that His Majesty desired the assembly to sit as soon as possible for the dispatch of business. ${ }^{2}$ He decided to allow the house to assemble in Beaufort and then at once prorogue them to meet in Charleston."

This plan was carried out. To the governor's intense chagrin, all the Charleston members left their private affairs and were at Beaufort when the session opened on October 8. Thirty-four members were present on the first day, an unusually large attendance. The Honorable Peter Manigault was again unanimously chosen speaker.' His Excellency kept the assembly waiting for three days before he received them to pre-

1 Public Records, Us., XXXIII, 174-17s.

2 Ibid., 163.

3 Itid., 179.

${ }^{4}$ Com. House Journals, Hs., XXXIX. Part I, 1-?. 
sent their speaker. They were then prorogued to meet at Charleston on the 22d. ${ }^{1}$

As may well be imagined, the commons house assembled on the appointed day in no very pleasant frame of mind. The first business attended to was the appointment of a committee on grievances, of which Captain Gadsden was chairman. The committee reported a series of resolutions on the 29th. They resolved that the calling of the assembly to meet at Beaufort, a place very distant from Charleston, and at that season of the year extremely unhealthy, was an act of ill will toward the freemen of the province; that it was an unwarrantable abuse of the royal prerogative; that the governor's conduct in keeping at Beaufort the fullest house that ever sat at the beginning of any session three dars before he would receive them with their speaker, and then immediately proroguing them, was adding insult to injury; and that his proroguing the assembly without allowing them to sit one minute as a legislative body was an evasion, if not a direct violation, of the election act, which required that sittings should not be discontinued longer than six months. The committee recommended that the agent in England should be instructed to lay before His Majesty an account of the governor's arbitrary conduct and attempt to secure his removal. ${ }^{2}$

His Excellency was on the lookout for these resolutions and carefully perused the house journals at the close of each day. On the evening of the day when the

${ }^{1}$ Com. House Journals, His., XXXIX. Part I, 4-6.

2Ibid., 20-21. 
report was made he sent as usual to the clerk of the house for the journals. That official announced that the speaker had taken them into his possession. Montagu at once wrote to the speaker for them, but they were not delivered until the next day, just before the meeting of the house. The manuscript was so blotted and interlined that it took lim some time to decipher it. When he finally arrived at the meaning of the resolutions, he determined to prevent their adoption by proroguing the assembly. Accordingly, he commanded their immediate attendance in the council chamber. The members of the house were expecting this move, however, and had already begun to consider the report. The discussion was kept up a few minutes after the receipt of the governor's message, and the report was agreed to and ordered to be published. The house then went up to the council chamber and were prorogued to November $9 .^{2}$

Montagu was thrown into a violent passion when he saw by the journals of the 30th that the house had continued to carry on business after receiving his order to attend in the council chamber. As soon as a quorum was secured on November 10, he severely reprimanded them for their conduct and pronounced their dissolution. ${ }^{3}$

Election writs were issued and a new assembly met January 6, 1773. The Honorable Rawlins Lowndes was

1 Rawlins Lowndes, Speaker Manigault having resigned on the 28 th. Com. House Journals, Ms., XXXIX, Part I, 17.

${ }^{2}$ Ibid., 25-26; Publie Records, .Hs., XXXIII, 188-189.

${ }^{3}$ Com. House Journals, Ms., XXXIX, Part I, 27-29. 
again chosen speaker and was presented to the governor for his approbation. He refused to approve of their choice and directed them to hold another election. On the following day, they sent up a verbal message asserting their right to choose their own speaker and persisting in the choice which they had made. His Excellency now prorogued the assembly for a few days, and, on the 12 th, issued a proclamation of dissolution. ${ }^{1}$

Another general assembly, the thirty-third and last of the royal period, was called to meet February 23, 1773. Among the popular leaders returned were Gadsden, Rutledge, Powell, Lowndes, Parsons, Bee, and the two Pinckneys, Charles and Charles Cotesworth. Before the day of meeting the house was prorogued to March 8. A quorum did not assemble until the 11th, one day after the governor's final departure for England. ${ }^{2}$

Weary of the urequal struggle and broken in health, Lord Charles Greville Montagu sailed for home in His Majesty's packet, The Eagle, March 10, 1773. ${ }^{3}$ Three months later, Lord William Campbell, governor of Nova Scotia, was transferred to South Carolina. As he did not come to the province for two years, the government devolved upon Lieutenant-Governor Bull for the fifth time. Although he still held a firm place in the confidence and affection of the people, Bull realized that he had a very difficult task before him.

${ }^{1}$ Com. House Journals, 11 s., XXXIX, Part II, I ; Public Records, Ms., XXXIII, 204-205.

2 Com. House Journals, Mf., XXXIX, Part II, l-3.

${ }^{3}$ Public Records, Ms., XXXIII, 225.

4 Ibid., I98, 231-255.

25 
The question was, could peace and good will be restored without the recall of the additional instruction, for it was evident that the British ministry had no intention of doing that.

The assembly met on the day following Lord Montagu's departure. Rawlins Lowndes was again chosen speaker and was formally approved by the lieutenant-governor. In his opening speech, Dr. Bull used very conciliatory language, making no reference to the recent disputes, but urging a consideration of the state of the public treasury. ${ }^{1}$ A tax bill for the years 1769 and 1770 was at once passed through two readings and sent to the council. It was rejected by them, because it contained the objectionable ten thousand five hundred pounds item and omitted the clause required by the additional instruction. The assembly then asked and obtained leave to adjourn until July $6 .^{2}$

The chief features of colonial history from 1773 to 1776 were the growth of the spirit of rebellion and the rapid development of a sentiment of union. Thus we find the South Carolina assembly spending part of their time in disputes with the governor and council over local issues and part in providing for a closer union with the other colonies. We shall take up first the local features and consider the final act in the struggle between the popular and prerogative elements. Then we shall trace the growth of the movement toward union, which made it possible for the South

1 Com. House Journals. Ms., XXXIX. Part II. 4-6.

2Ibid., 17, 23: Publie Reeords, Us., XXXIII, 227. 
Carolinians to oppose His Majesty's army as obstinately as they had opposed his governor.

The additional instruction of 1770 still continued to give trouble, but public attention was soon drawn to another dispute which threatened to overthrow the whole constitution of the province. This was nothing less than a renewal, in a more aggressive form, of the old attack on the right of the council to sit as an upper house of the legislature. The question first came up during Governor Glen's administration. It will be remembered that he became so angry at being excluded from participation in the council's legislative duties, as to openly deny their right to act in any but an advisory capacity. The assembly thought this a good opportunity to get rid of their conservative opponents altogether. About the year 1745, two of their members visited the governor in a private eapacity, and desired to know whether he would ratify a bill presented to him by the assembly, without sending it to the council, as usual, for their concurrence. Seeing that the assembly would gain more by the proposed change than he would, and realizing the difficulty he would have in explaining his conduct at home, Glen gave a negative reply. ${ }^{2}$

This gave a check to the attacks, but they were renewed occasionally in debate, especially when the council opposed some of the schemes of the assembly. The assembly stopped using the terms upper house and lower house entirely. They refused to receive a message, July 6,1764 , because it was signed by the speaker,

${ }^{1}$ Public Records, $H$ s., XXXIII, 306. 
which implied that the council was a branch of the legislature. Later in the same month, the council took a bold stand and refused to receive a commuincation from the assembly because it was not addressed to the upper house. They were forced to yield the point however, and accept messages addressed to His Majesty's Council. ${ }^{1}$

Similar attacks were made from time to time in the newspapers. The thorough discussion of the question by T-_-s W- - $\mathrm{t}$ in the Gazette of May 13, 1756, has already been noticed. ${ }^{2}$

The assembly did not restrict themselves to making claims, but gradually extended their actual powers. In a letter to Lord Hillsborough, of November 30, 1770 , Lieutenant-Governor Bull compared the relative positions of the two houses at that time with what they had been a few years before. Business, he stated, had formerly been planned by joint committees of council and assembly, and differences settled in conferences. The assembly had broken off this intercourse, however, and there had not been a conference in ten or fifteen years. Furthermore, the council seldom initiated any legislation at all, and never dared to introduce or amend a money bill. ${ }^{3}$

The dispute was renewed in the following manner: During the August session of 1773 , the assembly passed a bill appropriating $£ 100,000$ to rebuild Fort Johnson and another to prevent the counterfeiting of the paper

1 Com. House Journals, Is., XXXVI, 109, 129.

2 See Chapter VI, Financial History, 325-327.

${ }^{3}$ Public Records, Ms., XXXII, 372-374. 
money of the other colonies, the last mentioned being the result of a representation made by the committee of correspondence of the Virginia House of Burgesses. ${ }^{1}$ After the bills had been before the council for several days, a message was sent up by the assembly urging haste, especially on the bill to prevent counterfeiting. Whether they were dissatisfied at the origin of the act, or whether they were unwilling to pass any measure until the assembly rendered obedience to the additional instruction is not clear, but, at all events, the third reading was postponed sine die. ${ }^{2}$

The members of the council at this time were Daniel Blake, Barnard Elliot, John Drayton, and his son William Henry Drayton, all native South Carolinians, and Sir Egerton Leigh, Thomas Skottowe, Thomas Knox Gordon, John Burns, and John Stuart, royal placemen. Blake and Burns were absent in England, and Stuart, superintendent of Indian affairs, was an extraordinary councilor, who rarely attended. ${ }^{3}$ John Drayton was a brother-in-law of Lieutenant-Governor Bull. His son, William Henry, had but recently secured a seat in the council through his able opposition to the non-importation agreement and the Wilkes fund grant.

When the motion to postpone the reading of the bill to prevent counterfeiting was adopted, the two Draytons obtained leave of the council to enter their protest on the journals. A copy of the said protest was published by Thomas Powell in the South Carolina Gazette

${ }^{1}$ Com. House Journals, Ms., XXX1X, Part II, 27-28.

2 Public Records, Ms., XXXIII, 310, 342-343.

3 loid., XXXIV, 228-229. 
of August 30. The council summoned Powell before them on the 31st, and, after resolving that the publication of any of their proceedings without their consent was a high breach of privilege and contempt of their house, ordered him to be committed to the common gaol in Charleston during their pleasure. A warrant of commitment was made out directed to Roger Pinckney, sheriff of Charleston district, and signed by Egerton Leigh, president of the upper house of assembly. ${ }^{1}$

Powell applied to Rawlins Lowndes and George Gabriel Powell, two of His Majesty's justices of the peace, for a writ of habeas corpus. Upon the return of the writ a formal hearing was held, and an order was issued for Powell's discharge from custody. ${ }^{2}$ In a long argument, Lowndes first stated it as a principle that either house of parliament had always had the right of committing to prison for breach of privileges, and that no court or judge would ever attempt to discharge a prisoner so committed. He then based his opinion on the fact that the council had no analogy to the House of Lords, was not independent and not hereditary, and, in short, was not a legislative body at all. They were always called by the king in his instructions, the council, and were merely authorized to consult and advise with the governor as to whether or not he should reject bills passed by the assembly. The mere right to advise the governor to accept or reject a bill could not imply all the privileges of an upper house of parliament. The commitment, therefore, was

I Public Records, Is., XXXIII, 318, 343.

2 Ibid., 320-322. 
to be considered merely as an act of the privy council, and of no more authority than if authorized by a private magistrate. Hence the subject had his remedy by habeas corpus. ${ }^{1}$ Colonel Powell's opinion was along the same line. He declared that he could not find on the most diligent inquiry that the council had ever been invested with the authorities, rights, and privileges of the House of Lords. ${ }^{2}$

The anger of the council at this proceeding was intensified by the fact that Lowndes and Powell were both members of the assembly, the former being speaker. On September 6, they resolved that the power of commitment was necessarily incident to each house of assembly, that the two justices had been guilty of an atrocious contempt of their house, and that a copy of these resolutions should be sent to the assembly, together with a message stating that they expected them to waive the privileges of Lowndes and Powell so that the council might take cognizance of their offense. ${ }^{3}$

The resolutions and message were laid before the commons house on September 8. After looking over all the papers in the ease, they resolved, by unanimous vote, that Powell's commitment was unconstitutional and oppressive and a dangerous violation of the liberty of the subject, that the speaker and Colonel Powell should be thanked for their able and impartial decisions, and the said decisions should be printed for the benefit

1 Com. Housc Journals, Ms., XXXIX, Part II, 82-86.

${ }^{2}$ Ibid., s6-87.

sIbid., 7S-79; Public Records, Ms., XXX11I, 345-347. 
of the public; that the message and resolutions of the council contained an indecent reflection on the conduct of Mr. Speaker and Colonel Powell and a gross insult to the assembly; and that the lieutenant-governor should be requested to suspend those members of the council who had ordered the commitment of Powell. At the same time, the committee of correspondence was ordered to write to the agent in England a full account of the council's conduct, and instruct him to lay the whole matter before the king and attempt to secure the removal of the objectionable councilors. ${ }^{1}$

In reply to an address from the house, LieutenantGovernor Bull stated that it would not be proper for him to comply with their request to suspend certain members of the council, since the dispute had already been submitted to the king for settlement, and he would doubtless signify his pleasure very soon. The assembly was adjourned from September 13 to January 11, $1774 .^{2}$

The highest court in the province was soon called upon to decide on the council's right to sit as an upper house. Printer Powell attempted to bring an action against Sir Egerton Leigh, president of the council, for false imprisonment. Mr. Edward Rutledge represented Powell's interests, and Mr. Simpson, clerk of the council, appeared in behalf of Sir Egerton. After a full argument on both sides in the court of common pleas, Chief Justice Gordon and the four assistant judges quashed the suit, declaring in express terms

1 Com. House Journals, Ms., XXXIX, Part II. 77-88.

2 Ibid., 93-94, 96, 98. 
that the council was an upper house of assembly and hence had the right to commit for contempt.'

On January 11, His Honor prorogued the assembly to March 1. A scheme to liquidate the public debt was now adopted, which entirely outwitted the council. The assembly began to audit the public accounts and to ascertain the sums due to the several public creditors, as if they intended to pass a tax bill. Their purpose was shown on March 24 by the adoption of a series of resolutions and orders. It was resolved, that, as the house had been prevented by the council for several years from providing for the public ereditors in the usual way, it was their duty to give all possible relief; and that this good purpose would be best effected by granting interest-bearing certificates to the several persons whose accounts had been audited and allowed by the house. The clerk of the assembly was ordered to make out certificates of the amount due each creditor, together with interest until January 1, 1774, and the house pledged themselves to insert these sums in the next tax bill. The certificates were to be signed by the clerk, and, in order to prevent counterfeiting, countersigned by any five of the following members of the house: Speaker Lowndes, Christopher Gadsden, Miles Brewton, Thomas Heyward, John Izard, Charles Pinckney, William Cattell, Thomas Bee, and Gideon Dupont, $\mathrm{Jr}^{2}{ }^{2}$

1 Public Records, Ms., XXXIII, 325-333. These were not the native judges appointed by Jieutenant-Governor Bull during the Stamp Act controversy, but paid officials from England appointed under the circuit court act of 1769 .

${ }^{2}$ Com. House Journals, Ms., XXXIX, Part II, 162-164. All debts contracted before January 1, 1773 were thus provided for. 
A double purpose was served by this plan. Not only were the public creditors relieved, but a medium of circulation was secured. The members of the assembly, who were for the most part wealthy merchants and planter's, agreed to receive the certificates in all payments made to them. Although the people passed it from hand to hand "with an eager impatience, almost like an liot iron,' this species of currency relieved the stringency caused by the scarcity of other money. The council protested vigorously against the whole proceeding, but Sir Egerton Leigh and the other placemen did not hesitate to accept certificates in payment for their services. Lieutenant-Governor Bull alone stood firm. Repeatedly urged to accept the amount due him, which was more than two thousand pounds sterling, he steadfastly refused. "I shall," he declared in a letter to the home government, "always prefer to any private emolument, the satisfaction arising in my own mind, from a consciousness of performing my duty to the King, and of my attachment to the true Interest of this Province which this expedient appears to me to have a tendency to undermine.",

The next important episode in the local history of the province was the suspension of William Henry Drayton from His Majesty's council. By the terms of the circuit court act of 1769 , the judiciary of the province was to consist of a chief justice and four assistant justices. All were appointed and sent out from England. One of the assistants, Mr. Justice Murray, died in January, 1774. As the number of circuits to be

${ }^{1}$ Public kecords, Ms., XXXIV, 36-40. 
filled required a full bench, it was necessary to appoint some one in the colony to serve until the vacancy was filled. Although there were a number of lawyers in the province, none would accept, because their practice was more lucrative and because the size of the circuits rendered the position a very arduous one. Finally, William Henry Drayton offered his services. In spite of his conduct in the Powell case, still fresh in the public memory, Bull and his council gladly accepted the offer.

Although not a lawyer by profession, Drayton was a man of broad and liberal training, having been $\epsilon \mathrm{du}-$ cated at Balliol College, Oxford. ${ }^{1}$ He liad already begun to give trouble to the placemen in the council, hence we may reasonably suppose that the unanimity of his appointment was due largely to a desire to get him away from Charleston as much as possible. Perhaps, too, there was some hope of restoring him to his old rôle of defender of the royal prerogative. But if the council had any such hopes, they were soon frustrated. Shortly before the meeting of the First Continental Congress, he published a pamphlet, entitled, "A letter from Freeman of South Carolina to the Deputies of North America Assembled in the High Court of Congress at Philadelphia," in which with graphic language he discussed the grievances of America and suggested a bill of rights. ${ }^{2}$

\footnotetext{
1 Drayton, Memoirs of the Revolution, I, xii-xiv; Public Records, Ms., XXXIV, 10.

2 Gibbes, Doeumentary History of the Ameriean Revolution (1764$1776), 11-39$.
} 
Though his name did not appear in connection with the letter, it was well known that Drayton was the author. His uncle, Lieutenant-Gorernor Bull, in a letter to the Earl of Dartmouth, ${ }^{1}$ gave him the following review: "It is replete with sentiments so derogatory to the Roval Prerogative and the Authority of Parliament, and the long established Constitution of Government in America that it cannot fail to excite indignation, while the futility, tautology, and triteness of arguments raise contempt." Bull declared that such conduct warranted removal from the council, but he had delayed taking such a step for two reasons: it would gain for Drayton the popularity with the discontented which he so much desired, and it would give some foundation for the charge that members of the council were denied the right of free speech. ${ }^{2}$

Taking ap the history of the courts, Freeman called attention to their former position, when the assistant judges were native Carolinians of wealth and independence serving without par, and contrasted it with the present bench, which was filled with needy placemen from England. Chief Justice Gordon and Associate Justice Coslett took offense at this allusion and presented a remonstrance to the lieutenant-governor urging Drayton's removal from the bench. ${ }^{3}$ For the next few months, remonstrances, answers, replies, and

1 The Earl of Dartmonth suceeded Lord Hillsborough in $17: 2$ as colonial seeretary of state.

2 Public Records. Ms., XXXIV, 210-211.

3 Gibbes. Documentary History of the Amcrican Rcvolution (1761$1776), 39-41$. 
rejoinders followed one another in rapid succession. ${ }^{1}$ The arrival of Judge Gregory early in December with His Majesty's mandamus to succeed Murray saved Lieutenant-Governor Bull the embarrassment of passing upon the case. Drayton was then absent on the northern circuit, which lay through Georgetown, Cheraws, and Camden, delivering his famous charges to grand juries in defense of the rights of the colonies. As soon as he returned, a supersedeas to his commission was issued. ${ }^{2}$

Drayton's career as a popular agitator was continued. Though still members of the council, he and Barnard Elliot were both delegates to the provincial congress held at Charleston, on January 11, 1775. The final breach with the council came about in a manner very similar to his first defection at the time of the Powell episode. The general duty law and a number of other statutes were to expire at the end of this session, but, according to custom, the session conld not be regarded as closed until the first prorogation after some law was passed. Thus, by a failure to legislate, these laws had been artificially kept in force for two years beyond the time when they would ordinarily have expired. The assembly, when they met in January, 1775, determined to pass some act, it mattered not what, in order to bring about the close of the session and hence the expiration of the general duty law. There had been no direct tax collected in several years, so the government would

1 Gibbes, Documentary History of the American Rerolution (1764$17.6), 41-70$.

${ }_{2}$ Pullic Records, $1 / s$., XXXIV, 225; Drayton, Memoirs of the Revolution, I, 151-152. 
thus be deprived of all its revenues. Attorney-General Leigh, president of the council, would be the chief sufferer, inasmuch as his salary was paid from this fund. Other placemen in the council would also feel its effects in the same manner. The assembly hoped in this way to force the passage of a duty act, which was a revenue bill, without the objectionable clause demanded by the additional instruction of April 14, 1770. ${ }^{1}$ Consequently they passed and sent to the council, "An Act to prevent the counterfeiting the paper money of the other colonies," the same that had caused so much trouble in the Powell case. After postponing consideration of the measure for some time on various pretexts, the council finally agreed to pass it, as well as a reviving and continuing act. The latter continued thirty-seven acts for one year and to the end of the next session. The general duty act was continued for one year absolutely, and the clause in regard to the treasurer was not inserted."

While the crown officials in council were making every effort to prevent a vote on the bill to prevent counterfeiting, Drayton entered a bitter protest against their conduct in the journals. Ther retaliated, on February 11, by voting an address to Lieutenant-Governor Bull, requesting his removal, on the general ground that he was influenced by a determined effort to destroy the confidence of the people in the upper house, to subvert the constitution, and to destroy the government. This

${ }^{1}$ Public Records, Ms.. XXXV, 7-8.

2Ibid.. 61: Statutes, IY, 331-335, 335-336. 
was carried by the vote of three placemen, Drayton himself being the only Sonth Carolinian present. ${ }^{1}$

Two days later, it was presented to the lieutenantgovernor, and he asked for the facts upon which the complaint was founded. ${ }^{2}$ These were given in a committee report, adopted February 22. He had, said they, entered captious and frivolous protests against the proceedings of the upper house and afterwards caused them to be printed in the public newspapers; ${ }^{3}$ he had attempted to bring the house into contempt by boasting outside of his malicious attacks upon a certain member whom he disliked; ${ }^{4}$ he had both within and without the council denied their right to sit as an upper house; and he had in the face of the house declared himself to be the author of the Freeman pamphlet. In conclusion, they stated that they could not be expected to lay any instances of breach of privileges before His Honor, as that was a subject of which their house alone was competent to judge. ${ }^{5}$

On the adoption of this report, a dissent was entered on the journals of the house, signed by John Drayton, William Henry Drayton, and Barnard Elliot, the only native Carolinians in the council. The report, they declared, was unparliamentary in almost every line,

1 Gibbes, Documentary History of the Ameriean Revolution (17641776), 70-71; Com. House Journals, Ms., XXXTX, Part II, 256-257.

${ }^{2}$ Com. House Journals, Ms., XXXIX, Part II, 257.

SDrayton's recent protest had been published in the South Carolina Gazette for February 13, 1775, two days after the vote of the council to request his suspension.

4 Chief Justice Thomas Knox Gordon.

5 Com. House Journals, Ws., XXXIX, Part II, 258-260. 
but they would confine themselves to two objections. In the first place, the council had sent an address to the king, September 11, 1773, complaining of a most dangerous adjudication that they were not a branch of the legislature.' Had His Majesty really thought that they were an upper house, he would certainly in the course of sixteen months have made some reply and taken steps to preserve them in their rights and privileges. His silence was out of tenderness to the house, being unwilling to refuse what he could not grant. In the second place, if Drayton were removed because of the Freeman letter, all confidence in the council would be lost. No independent American would care to accept a seat in council on a tenure so precarious. ${ }^{2}$

Drayton himself drew up an humble representation and sent it to Lieutenant-Governor Bull on February 27. His defense, he affirmed, turned upon one question, "Did His Majesty's Council, sitting in the Council Chamber, of themselves form an Upper House of Assembly and a branch of the Legislature?" He took the negative side. During the Powell controversy the court of common pleas decided that the council was an upper house, while another competent tribunal adjudged at the same time that it was not. The king, though applied to by the council sixteen months previously, lrad not yet declared them to be an upper house of assembly, nor had the governor at any time

I The decision of Speaker Lowndes and Colonel Powell in the printer Powell case.

2 Com. House Journals, IIs., XXXIX, Part II, 260-261; Gibbes, Documentary History of the American Revolution (1764-1776), 75-77. 
ever given them that title. "Thus," said he, "there is one express adjudication, and two strongly implied opinions of high authority, besides the voice of the people, against the claim of the Council, supported only by one adjudication."

Having thus stated the question and given his arguments in the negative, Drayton went on to show how it applied to his own case. The council, while complaining to the lieutenant-governor of his conduct in assembly, had declared that parliamentary offenses were subjects of which their house alone was competent to judge. If his Honor really regarded the council as an upper house, he could not constitutionally call him to account for any speech, debate, or proceeding in assembly. If, on the other hand, he did not allow him the privileges of assembly, he would in effect declare that the council was not an upper house, and that the judgment in Powell vs. Leigh was contrary to law and justice. $^{1}$

This ingenious argument did not have any effect on Lieutenant-Governor Bull, for, on March 1, Drayton was formally suspended from the council until His Majesty's pleasure could be known. ${ }^{2}$ On the 4th, he laid all the papers relating to the matter before the commons house of assembly, together with a memorial filled with complaints of the powers and constitution of the council. All were referred to the committee on grievances, but no report seems to have ever been made.

${ }^{1}$ Com. House Journals, Ms., XXXIX, Part II, 262-267.

2 Ibid., 268. 
Other questions of more importance had begun to occupy the attention of the house. ${ }^{1}$

The assembly adjourned from March 4 to April 20. On the 26th they resolved to defray the expenses of the government for the year 1774 , and ordered a committee to bring in a schedule of charges. ${ }^{2}$ A rumor that the newlr-appointed governor, Lord William Campbell, would soon arrive, led to an adjournment on Mas 1 for one month. They met again on June 1, and before sending up the usual notification to His Honor, read and approved the estimates for the year 1774 , and ordered their clerk to grant certificates to the various public ereditors. They had barely done so, when they were summoned to the council chamber and adjourned to .June $19 .^{3}$

Governor Campbell reached Charleston June 17, 1775 , one day after the first meeting of the council of safety appointed by the provincial congress.' Meetings of the assembly continued to be held when a quorum could be secured, but very little business was . attended to, since the council of safety had become the real governing body of the province. The assembly was formally dissolved on September 15, Governor Campbell fled from the town, and royal government in South Carolina came to an end.

In the meantime the union morement had been making rapid progress. On March 12, 1773, the Virginia

${ }_{1}$ Com. House Joumals, Ms., XXXIX, Part II, 254-269.

2 Ibid., 276.

${ }^{3}$ Ibid., 285-288.

4 Public Records, Ms., XXXT, 117: S. Car. His. Soc. Col., II, 22.

${ }^{5}$ Cum. House Journals, Ms., XXXIX, Part II, 314. 
House of Burgesses adopted those famous resolutions, which originated the institution of intercolonial committees of correspondence. ${ }^{1}$ The most important of these resolutions was the following:

"Be it Resolved, That a standing Committee of Correspondence and Enquiry be appointed to consist of eleven persons, to wit, The Honorable Peyton Randolph, Esquire, Robert Carter Nicholas, Richard Bland, Richard Henry Lee, Benjamin Harrison, Edmund Pendleton, Patrick Henry, Dudley Digges, Dabney Carr, Arehibald Cary, and Thomas Jefferson, Esquires, any six of whom to be a Committee, whose Business it shall be to obtain the most early and authentic Intelligence of all such Acts and Resolutions of the British Parliament, or proceedings of Administration, as may relate to or affect the British Colonies in America; and to keep up and maintain a Correspondence and Communication with our Sister Colonies, respecting these important Considerations; and the Result of such their Proceedings from Time to Time to lay before this House."

Another resolution instructed the speaker to transmit copies of the resolutions to the speakers of the various colonial assemblies, and to desire that they would lay them before their respective houses and request them to appoint some person or persons to communicate from time to time with the Virginia committee. ${ }^{2}$

When the South Carolina assembly came together on July 8, Speaker Lowndes submitted to them a copy

${ }^{1}$ There had, to be sure, been committees of correspondence. in the Massachusetts towns sereral months before this, but Virginia was the first to extend the principle to intercolonial relations.

${ }^{2}$ Com. House Journals, Hs., XXXIX, Part II, 25-27; Bancroft, Hist. of the United states, Edition, 1S7S. IV, 258-259. For a copy of the resolutions, see William Wirt, Life of Petriel: Henry, Third Edition, $\mathrm{si}-\mathrm{ss}$. 
of the Virginia resolutions, together with a letter from Speaker Randolph. They approved them unanimously and then resolved that the speaker and any eight of the other members of the committee of correspondence should constitute a committee to correspond with the Virginia committee and similar ones in the other colonies. $^{1}$

Seeing that there was no disposition on the part of the assembly to proceed to business, His Honor prorogued them from July 8 to August 9 . On the third day of the new session, a letter was read from the Honorable Metcalf Bowler, speaker of the Rhode Island House of Deputies, dated May 15, 1773, notifying them that Rhode Island had, on May 7, appointed a committee of correspondence, being led thereto by the resolutions from Virginia. Speaker Lowndes was ordered to write to the Rhode Island speaker and enclose him a copy of the resolutions of July 8. A similar letter was received a few days later from Speaker Cushing of the Massachusetts house and its was answered in the same manner. ${ }^{2}$

On March 8, 1774, Speaker Lowndes submitted to the assembly letters that he had received from the speakers of the lower houses in Connecticut, Maryland, and New-

${ }^{1}$ Com. House Journals, Ms., XXXIX, Part II, 25-27. The standing committee referred to was one that had long been appointed by the house to correspond with the agent in England. They had, up to the last few years, acted in conjunction with a committee from the council. There were at this time eighteen members, among them being Gadsden, Rutledge, Parsons, and the two Pinckneys. See Chapter IV, Colonial Agents.

I Ibid., 30, 34-35, 55-58. 
castle, Kent, and Sussex-upon-Delaware enclosing resolutions providing for committees of correspondence. The assembly ordered the speaker to reply to the various letters and enclose their resolutions on the subject, and instructed the committee of correspondence to inform the other colonial committees of South Carolina's grievances relating to the additional instruction from the king and the assumed power of the council to commit for breach of privilege. ${ }^{1}$

The month of September, 1774, witnessed the most important step that had yet been taken toward union. The First Continental Congress was convened in Philadelphia to consider the Boston Port Bill and other colonial grievances. At a meeting of the inhabitants of South Carolina held at Charleston, July 6, 7, and 8, Henry Middleton, John Rutledge, Thomas Lynch, Christopher Gadsden, and Edward Rutledge were chosen to represent the province at the congress."

In the meantime, the assembly had adjourned from March 26 to May 3. They were prorogued from time to time, and did not meet again for business until August $2 .^{3} \quad$ Lieutenant-Governor Bull, being well aware that they would discuss continental rather than provincial affairs, decided to prorogue them again as soon as they met." The members of the house, however, had some particular business to attend to, and were determined to outwit him. The usual time for

1 Com. House .Journals, Ms., XXXIX, Part II, 113.

2 Itid, 172.

Ibid., 170-172.

4 Public Records, Ms., XXXIV, 18\%. 
their meeting was about ten or eleven o'clock in the morning. On this occasion, they met at eight and, in accordance with the usual custom, sent two members to acquaint His Honor of their meeting. Bull hastened to the council chamber, summoned one or two councilors, and prorogued the assembly to September 6 . All this was done in less than twenty minutes, but it gave the assembly ample time to carry out their business, which had been earefully planned beforehand. Colonel Powell acquainted them of the meetings held on July 6,7 , and 8 to elect delegates to the Philadelphia congress. They resolved unanimously to ratify the said election and to repay with interest any one who would advance fifteen hundred pounds sterling to pay the expenses of the delegates. ${ }^{1}$

Only a few members were present on September 6, and the assembly was continued by various prorogations until January 24, 1775, when a quorum met for business. The journals of the Continental Congress were laid before them and they passed resolutions expressing their approbation of the proceedings and thanking the members in general, and those from South Carolina in particular, for their services. As another congress was to be held in May, the same five deputies were again chosen, and fifteen hundred pounds sterling were voted to defray their expenses. ${ }^{2}$ This election was in reality merely a confirmation of a choice made by the

\footnotetext{
${ }^{1}$ Public Records, IIs., XXXIV, 188-189, 193-198; Com. House Journals, Ms., XXXIX, Part II, 172-174.

${ }^{2}$ Com. House Journals, Ms., XXXIX, Part II, 189-192.
} 
provincial congress, an extra-legal body which met in Charleston on January $11 .{ }^{1}$

The history of the Second Continental Congress is too well known to need repetition. It assumed sovereign powers because it had the support of the American people. Common interests and common dangers had already molded the thirteen separate colonies into one great commonwealth. Armed rebellion now became possible, and the idle hopes of a few patriots, such as Gadsden and Samuel Adams, were replaced by the longings of a nation for its independence.

'Drayton, Memoirs of the Revolution I, 176; Public Records, Ms., XXXV, j-s. 



\section{APPENDIX}

\section{General Assemblies of the Royal Period}

First.......... July 27, 1721 - June 16, $1724{ }^{1}$

Second.............Feb., 1725 - Nov., 1727. ${ }^{2}$

Third............Jan. 31, 1728 - May 11, 1728.

Fourth............July 9, 1728 - July 27, 1728.

Fifth............. Sept. 17, 1728 - Nov. 23, 1728.

Sixth..............Jan. 15, 1729 - Feb. 21, 1729.

Seventh............Aug. 6, 1729 - Oct. 17, 1729.

Eighth..............Dec. 2, 1729-Apr. 29, 1730.

Ninth.............Jan. 20, 1731 - Sept. 26, 1733.

Tenth................. 15, 1733 - Sept. 30, 1736.

Eleventh.......... Nov. 10, 1736 - June 7, 1739. ${ }^{3}$

Twelfth.............Sept. 12, 1739 - Aug. 3, 1742.

Thirteenth........... Sept. 14, 1742-Summer of 1745 .

Fourteenth............ Sept. 10, 1745 - July 31, 1746.

Fifteenth..............Sept. 10, 1746-July 23, 1747.

Sixteenth.............Fall of 1747 - Nov. 19, 1747.

Seventeenth...........Jan. 19, 1748 -Summer of 1748 .

Eighteenth............ Jan. 10, 1749 - Feb. 14, 1749.

Nineteenth............ Mar. 28, 1749 - Oct. 4, 1751.

Twentieth............. Nov. 14, 1751 - Sept., 1754.

1 Unless otherwise stated the dates given here are the day named in the election writ for the assembly to convene and the day of its dissolution. The fifth, serenth, sixteenth and eighteenth assemblies never contained a legal quorum, so were dissolved without being organized.

2 Existence terminated by the death of George $I$.

3 Date of the last meeting. Dissolved shortly afterwards. 
Twenty-first........... Nov. 12, 1754-Aug. 25, 1757.

Twenty-second........... Oct. 6, 1757 - Aug. 23, 1760.

Twenty-third........... Oct. 6, 1760 - Jan. or Feb., 1761. ${ }^{1}$

Twenty-fourth........... Mar. 26, 1761 -Dec. 26, 1761.

Twenty-fifth............Feb. 6, 1762 - Sept. 13, 1762.

Twenty-sixth.......... Oct. 25, 1762 - Sept., 1765.

Twenty-seventh......... Oct. 28, 1765 - Sept. 8, 1768.

Twenty-eighth......... Oct. 25, 1768 - Nov. 19, 1768.

Twenty-ninth............Mar. 21, 1769 - Nov. 5, 1771.

Thirtieth...........Apr. 2, 1772 - Apr. 10, 1772.

Thirty-first............ Oct. 8, 1772-Nov. 10, 1772.

Thirty-second..........Jan. 6, 1773 - Jan. 12, 1773.

Thirty-third........... Feb. 23, 1773 - Sept. 15, 1775.

Colonial Officials of the Royal Period

\section{Governor}

Francis Nicholson................ 1721-1725.

Arthur Middleton.................1725-1730."

ROBERT JoHNSON.................1730-1735.

Thomas Broughton................1735-1737.

Willia

JAMES GLEN..................1743-1756.

William Henry Lyttlleton. . . . . . . . . 1756-1760.

William Bull, The Second........1760-1761.

Thomas Boone...................1761-1764.

William Bull, The Second.........1764-1766.

1 Terminated by death of George II.

2 President of the council and acting governor.

3 Lieutenant-Governor.

- President of the council (1737-1738), lieutenant-governor (1738$1743)$.

b Lieutenant-governor. 
Lord Charles Greville Montagu . . . . 1766-1768.

William Bull, The Second.........1768. ${ }^{1}$

Lord Charles Greville Montagu. . . . 1768-1769.

William Bull, The Second..........1769-1771.

Lord Charles Greville Montagu. . . . 1771-1773.

William Bull, The Second.........1773-1775.

Lord William CaMpbell. . . . . . . . . . 1775.

\section{Public Treasurer}

Alexander Parris... . . . . . . . . . . . . . 1712-1735.

Gabriel Manigault. . . . . . . . . . . . . . 1735-1743.

Јасов Мотте.................... 1743-1770.

Henry Peronneau and Benjamin Dart. 1771-1776. ${ }^{2}$

\section{Powder Receiver}

Miles Brewton...................1717-1745.

Robert Brewton.................. 1745-1759.

J АCOB Motte, Jr..................1759-1760.

JAMES REID....................1760-1776.

\section{Secretary of the Province}

Charles Hart..................1716.(?)-1732.

John Hammerton.................. 1732-1762.

Thomas Skotrowe................1762-1775.

\section{Commissary General}

Peter Taylor.................... 1735-1737.

JOHN DART..................... 1737-1755.

${ }^{1}$ Bull's third administration (1768) extended over the summer months while Governor Jontagu was in the northern colonies.

2 Assistant Treasurer Peronneau performed the duties of the office during the interval between Motte's death and his own election. 
William Pinckney............... 1755-1766.

Benjamin Simons.................1766-1771.

George Sheed..................1771-1776.

Patentees.

Provost Marshal

Thomas Lowndes and Hugh Watson...1725-1759.' Richard Cumberland.............1759-1772."

Duties of office exercised by deputies.

William Loughton... . . . . . . . . . . . 1721-1725.

George Bampfield................ 1725-1733.

RoBert HaLL.......................1733-1740.

William Willingson............1740-1742.

Samuel Hurst... . . . . . . . . . . . . . 1742-1745.

Rawlins Lowndes.. . . . . . . . . . . . . . . 1745-1754.

Charles Lowndes.. . . . . . . . . . . . . 1754-1758.

AdAM WoOd.........................

Daniel DoYlex..................1760-1764.

Roger Pincknex.................1764-1772.

\section{Attorney-General}

Benjamin Whitaker..............1721-1731.

James Abercrombie. . . . . . . . . . . . . . . 1731-1732.

Charles Pinckney.................1732-1733.

James Abercrombie. . . . . . . . . . . . . . 1733-1742.

JAMES WRIGHT....................1742-1757.

David Graeme..................... 1757-1764.

James Moultrie........................

1 Lowndes and Watson reccived a commission for life from the proprietors in 1725 and one from the king in 1730 . Watson died in 1759 . Mention is made in the journals of George Morley as patentee (1745). He had probably purchased the Lowndes interests.

2 Cumberland's interests were purchased by the province in 1767 . His deputy still exercised the dutics of the oflice until the circuit court act was put into force in 1772 . 
JoHN RutLEdge.................1761-1765.

Sir Egerton Leigh................. 1765-1774.

JaMEs Simpson...................1774-1775.

Surveyor-General of Lands

JAMES St. JoHN.................1731-1743.

George Hunter. . . . . . . . . . . . . . . 1743-1756(?).

Egerton Leigh................. 1756(?)-1772.

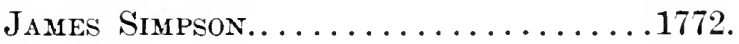

Egerton Leigh...................1772-1775.

Receiver-General of the Quit Rents

JohN HaMmertoN . . . . . . . . . . 1732-1742.

George Saxbi.........................

Thomas IRving................1774-1775.

Chief Justice

Francis Yonge..................

Charles Hill. . . . . . . . . . . . . . . . 1721-1724.

Thomas Heptorth..............1724-1727.

Richard Allein...................

Robert Wright......................

BeNJAMIN Whitaker.............1739-1749.

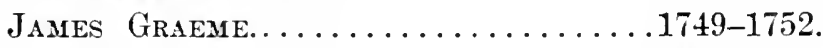

Charles Pinckney...............1752-1753.

Peter Leigh................... 1753-1759.

JAMES Michie...................

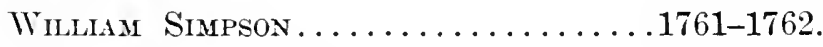

Charles Skinner...............1762-1767. ${ }^{3}$

Thomas Knox Gordon..............1771-1775.

1 Hammerton was the first receiver-general appointed after the crown had purchased the proprietary interests in 17:9.

2 'The office was racant from Skinner's suspension in 1767 to Gordon's appointment in 1771. Judicial business was attended to by the assistant justices. William Wragg was offered the chief justiceship in 1769 and again in $17 \% 0$, but he refused to accept. 


\section{Judge of the Court of Vice-Admiralty}

James Sмiтh...................1721-1724(?).

WrLliaM Blakeway...............1724-1727.

BenJaMin Whitaker...............1727-1732.

William Trewin...............1732. ${ }^{1}$

BenJAMIN WhitaKer..............1732-1736.

Maurice Lewis. . . . . . . . . . . . . . . . . . 1736-1739.

William Trewin...................1739-1741.

James Graeme..................1742-1752.

James Michie................... 1752-1758.

Peter Leigh...................... 1758. ${ }^{2}$

James Michie................... 1752-1758.

JoHN Rattray..................1760-1761.

Egerton Leigh. . . . . . . . . . . . . . . 1761-1768.

James Michie . . . . . . . . . . . . . 1758-1760.

Sir Augustus Johnson. . . . . . . . . . 1769."

Edward Savige ................1771-1775(?).

\section{Speaker of the Assembly}

JAMES MoORE.................1721-1724.

Thomas Hepworth...................1724.'

Thomas Broughton. . . . . . . . . . . . 1725-1727.

Thomas Fenwicke..............1727.

Willam Dry..................... 1728-1729.

JoHN LLOYd........................1730-1731.

1 Deputy under Whitaker.

$\checkmark$ Deputy under Michie.

3 After the reorganization of the admiralty in 1768 Johnson was appointed judge for the southern district. He authorized Simpson to act in his absence. The new plan seems to have failed, for in 1771 Savage received a commission from Lieutenant-Governor Bull as provincial judge. How long he served is uncertain.

4 From March 25 to June 16.

5 August 29 to November. 
William Dunaning.................... $17311^{\prime}$

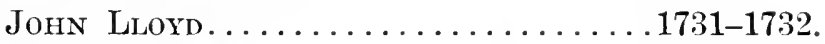

Robert Hume.................. 1732-1733.

PaUl JeNYs................... 1733-1736.

Charles Pinckney................. 1736-1740.

Wiliam Bull, Junior............... 1740-1742.

Benjamin Whitaker............... 1742-1744.

Wiliam Bull, Junior............... 1744-1747.

Henry Middleton................ . 1747. ${ }^{2}$

Wiliam Bull, Junior.............1748-1749.

Andrew Rutledge................1749-1752.

JAMES Mrchie..................... 1752-1754.

Henry Middleton... . . . . . . . . . . . . . . 1754-1755.

BenJamin Smiti..................1755-1763.

Rawlins Lowndes.................. 1763-1765.

Peter Manignult................1765-1772.

Rawlins Lowndes.................. 1772-1775.

\section{Colonial Agent}

Abel Kettleby.................. 1712-1716.

Joseph Boone ANd Richard Beresford. .1715-1716.

Joseph Boone..................1716-1720.

Rowland Tryon................1720. ${ }^{3}$

Francis Yonge and John Lloyd. . . . . 1721-1722.

Francis Yonge.................1722-1727.

Samuel WragG...............1727-1728.

Stephen Godin....................1729.

I July 7 to November 17.

1 January 27 to July 23.

3 Mentioned as co-agent with Boone. Com. Housc Journals, Ms., V, $433-434$.

4 There was no regular agent from 1728 to 1731 . Godin represented the council in the paper money controversy. 
416 SOCTH CAROLINA AS A ROYAL PROVINCE

Peregrine Furt.................. 1731-1749.

Francis Tonge...............1733. ${ }^{1}$

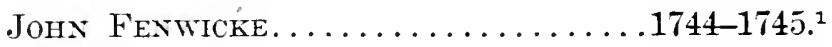

James Crokatt. ................... 1749-1757.

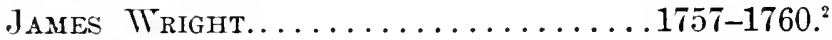

Charles Garth................1762-1775.

superintendent of Indian Affairs

Edilind Atkix...................1756-1762.

John Stuart..................

1 Sent to cö̈perate with the regular agent in urging some particular measure. There were many examples of such special agencies.

2 The office was vacant from 1760 to 1762 . 


\section{LIST OF AUTHORITIES QUOTED.}

Admiralty Court Reconds, 1716-1763. Manuseript 3 vols. Office of the Clerk of the United States District Court, Charleston.

Ayericas Historical Review.

Baxcroft, George. History of the United States. 6 vols. Boston, $18 \% 8$.

Barry, Johy S. The History of Massachusetts. 3 vols. Boston, 1855$185 \%$.

Bishop, Joel P. New Criminal Procedure. Fourth Edition. 2 vols. Chicago, 1895-1896.

Blackstoxe. Commentaries on the Laws of England. Edited by George Sharswood. 2 vols. Philadelphia, 1860.

Brownell, Cifarles. The Indian Races of North and South America. New York, 1853.

Carroll, B. R. Historical Collections of South Carolina. 2 vols. New York, 1836.

Chalmers, George. Opinions of Eminent Lawyers on Various Points of English Jurisprudence, chiefly concerning the Colonies, Fisheries, and Commerce of Great Britain. Cited as Colonial Opin. ions. Burlington, 1858.

Charlestox Year Books.

Coxe, Bristox. An Essay on Judicial Power and Unconstitutional Legislation. Philadelphia, 1893.

Commoxs House Journals. Manuscript. 39 vols. Office of Secretary of State, Columbia.

Cotxcil Jocrials. Manuscript. 38 vols. Office of Secretary of State, Columbia.

Dictionary of Natioxal Biography.

Draytox, Jonx. Memoirs of the American Revolution. 2 vols. Charleston, 1821 .

Forsith, Williay. Cases and Opinions on Constitutional Law. London, 1869.

Gieses, R. W. Documentary History of the American Revolution. 3 rols. Columbia, 1853, and New York, 1857.

27

417 
Greene, Evarts B. The Provincial Governor in the English Colonies of North America. Harvard Historical Studies. Vol. VIl. New York, 1898.

Harris, Thaddeus M. Biographical Memorials of James Oglethorpe. Boston, 1841.

Hewatt, Rev. Alexander. An Historical Account of the Rise and Progress of the Colonies of South Carolina and Georgia. 2 vols. London, 1779. This is reprinted in Carroll's Collections, vol. I. Huguson, Sirurley C. Carolina Pirates and Colonial Commerce. Johns Hopkins University Studies. Vol. XII. Baltimore, 1894.

Johnson Manuscripts. Documentary History of New York, vol. II. Albany, 1850.

Jones, Charles C. The History of Georgia. 2 vols. Boston, 1883.

Kerby, D. M. An Historical Sketcl of the Equitable Jurisdiction of the Court of Chancery. Cambridge, 1890.

Landrum, J. B. O. Colonial and Revolutionary History of Upper South Carolina. Greenville (S. C.), 1897.

Lecky, W. E. H. A History of England in the Eighteenth Century. Second Edition. 8 vols. London, 1883.

McCrady, Edward. The History of South Carolina under the Proprietary Goverument (1670-1719). New York, 1897.

The History of South Carolina under the Royal Government (1719-1776). New York, 1899.

Maitland, F. W. Justice and Police. London, 1885.

Maryland ARchives. Correspondence of Governor Sharpe. 3 vols. Baltimore, 1888-1895.

Massachusetts Historical Society Proceedings. First Series, vol. XVII. Boston, 1880 .

Mereness, N. D. Maryland as a Proprietary Province. New York, 1901.

Milus, RoBert. Statistical Atlas. Manuscript. Office of the Secretary of State, Columbia.

New Jersey Archives. First Series, vols. II, IX. Newark, 1881, 1885.

New YoRk Colonial Documents. Vols. VI, VII, IX. Albany, 18551856.

New York, Documentary History of. 4 vols. Albany, 1850-1851.

Nisi Prius Reports. 3 Campbell, 97. New York, 1821. 1 Ryan and Moody, 166. London, 1827.

North Carolina Colonial Records. 10 vols. Raleigh, 1886-1890.

OGLEThorpe LetTERs. Collections of the Georgia Historical Society. Vol. III. Savannal, 1873. 
Osgood, Herbert I. The Colonial Corporation. Political Science Quarterly. Vol. XI. 1896.

The Proprietary Province as a form of Colonial Government. American Historical Review. Vols. II, III, 1896-1899.

Palfrey, J. G. History of New England. 5 vols. Boston, 1890-1897. Parliamentary History of England. Cobbett and Hansard. Vol. XVI. London, 1813.

Penssylvania Archives. Edited by Samuel Hazard. Vol. IV. Philadelphia, 1853.

Political Science Quarterly.

Phince Societx Publications. Randolph Papers. Part XVI, 5 vols. Boston, 1898-1899.

Public Records. Manuscript. 36 vols. Office of the Secretary of State. Columbia.

Public Records, Extra. Manuseript. 4 vols. $^{1}$

Quit Rents. Manuscript. Office of the Secretary of State. Columbia.

Ramsay, David. The History of South Carolina. 2 vols. Charleston, 1809.

Raisey, J. G. M. The Annals of Tennessee. Charleston, 1853.

Rivers, W. J. A Sketch of the History of South Carolina to the close of the Proprietary Government, 1719. Charleston, 1856.

Schaper, William A. Sectionalism and Representation in South Carolina. Annual Report of the American Historical Association for 1900. Vol. I, 237-463. Washington, 1901.

Silaftesbury Papers. South Carolina Historical Society Collections. Vol. V. Charleston, 1897.

Sound Currency. Vol. V, No. 4. New York, February 15, 1898.

South Carolina Gazette. 1732-1775.

South Carolina Historical Society Collections. 5 vols. Charleston, $1857,1858,1859,1887,1897$.

Spence, George. The Equitable Jurisdiction of the Court of Chancery. 2 vols. London, 1846-1849.

Statutes at Large of South Carolina.

a. Thomas Cooper and David J. MeCord. 10 vols. Columbia, 18361841.

b. John F. Grimké. 1 vol. Philadelphia, 1790.

Statutes at Large (of England and Great Britain).

${ }^{1}$ These extra volumes contain portions of the council and assembly journals copied in the British Public Record Office to fill the gaps in the journals at Columbia. 
TAxxer. Edwix P. Colonial Agencies in England during the Eightcenth Centurs. Political Science Quarterly. Vol. XVI, 1901.

Wallace, D. D. Constitutional History of South Carolina from 172.5 to 1775 . Abbeville (S. C.), 1899.

Tashbtrs, Eyrory. Sketches of the Judicial History of Massachusetts. Boston, 1840.

Whitrey, Edsox L. Government of the Colony of South Carolina. Johns Hopkins University Studies. Tol. XIII. Baltimore, 1895.

Wirt, William. Sketches of the Life of Patrick Henry. Third Edition. Philadelphia, 1818. 


\section{INDEX.}

Abbeville county, 18, 212.

Abercrombie, James, goes to England to solicit service of independent troops, 193; attorneygeneral, 412.

Adams, Samuel, 407 .

Additional instruction of April 14, 1770 , dispute over, $170,373-387$. See Wilkes fund controversy.

Admiralty court, 84, 14i-156, see table of contents; records diseussed, 150.

Ad valorem duties, 285-286.

Agent in England, 158-170, see table of contents: instructed to protest against the Townshend acts, 361 ; mentioned, 392; list of agents, 415-416.

Akin, James, elected to the assembly (1725), governor refuses to administer the state oaths, 98-99.

Allein, Richard, chief justice, 123, 413; member of the committee of correspondence, 162 ; dispute with the assembly in the Landgrave Smith case, 251, 261-262; elected to the assembly, 267 .

Allen, Andrew, member committee of correspondence, 162 .

Allen, Eleazar, clerk of the assembly, 114; puisne baron of the court of exchequer, 156.

Altamaha Fort. See Fort King George.

Amherst, General, sends officer to train the artillery company in Charleston, 178.

Amory, Jonathan, adrocate in the court of vice-admiralty, 148 .

Any, Thomas, cacique, 35.
Amyand, lsaac, elerk of the assembly, 114 .

Andros, Edmund, landgrave, 34 .

Archdale, John, governor, settles quit rent dispute, 8, 29-31; fortifies Charleston, 196.

Artillery company established in Charleston, $17 \%-178$.

Ash, John, agent of the dissenters in England, 159.

Ashley River Ferry Town in Berkeley county, 85 .

Ashley's bastion, location of, 197. Assembly, 95-117, see table of con. tents; power of appointing public officials, 15-20; usurps control over expenditure of money, 220, 305, 370-386, see table of contents; encroaches on the governor's minitary powers, 2.20-2.2.2; imprisons merchants of Charleston for petitioning against a legal tender bill, 237239 ; passes resolutions criticising President Middleton and the council, 349; declares that the right of representation is constitutional, not statutory, 343345 ; denies the force of royal instructions, 309,374 , see Wilkes fund controversy; powers of assembly and council compared, $332, \quad 385$; assembly attacks council's right to sit as a legislative body, 387-393; votes to defray expense of delegates to the Continental Congresses, 406 ; list of general assemblies, $40 !$ 410.

Atkin, Edmund, member of the council, 315 ; superintendent of 
Indian affairs for the southern district (1756-1762). 224, 416. Attorneys-General, list of, 412413.

Axtell, David, landgrave, 34.

Bampfield, George, deputy prorost marshal, 412.

Barbadoes. concessions. 4; settlers from, 6. 172; Barbadian in. fluence, 11, 17.

Barnwell county, 184 .

Barnwell. Colonel John, member of the committee of correspondence, 162; constructs Fort King George. 209.

Barry, Thomas, 155.

Bayley, John, dispute over election of as clerk of the assembly, 111-114.

Beale, Othniel, colonel of infantry, 178 ; superintends building of fortifications, $\quad 199, \quad 204-206$; sent as commissioner to Georgia, 218-219; eandidate for public treasurer, 312; elected to the assembly, 316 .

Beaufort county, 184.

Beaufort galler, 188-189, 191-192.

Beaufort judicial district created, $135,141$.

Beaufort, Port Roval, court established at, 146; assembly meets at, 381-383.

Bee, John, dissenter, refuses to take the oath on the Erangelists, 99.

Bee, Thomas, member of the assembly, 342, 385, 393; attorney in the case of Jordan versus Law, 354.

Beresford, Richard, colonial agent, $160-161,415$; member of the committee of correspondence, 162.

Berkeley county, created, 6; divided into parishes, 10,11 ; mentioned, $7,9,56,120,145-146$, 174 .
Bernard, Gabriel, engineer, superintends building of fortifications, 195-199.

Bill of Pights Societr, founded in London to pay the debts of John Wilkes, 370.

Bills of credit, 230-275, see table of contents; issued to build court houses and gaols, 140; amount of at various times, $\mathbf{2 5 \pi}$, 274.

Bishop of London, eneroachments upon the jurisdiction of, 10 .

Blake, Daniel, member of the council, 359.

Blake. Joseph, deputy governor, S, 196 ; colonel of cavalry, 173.

Blake's bastion. location of, 196 .

Blakeway, William, fails in his candidacy for powder receiver, $18-19$; nember of the committee of correspondence, 162 ; judge of vice-admiralty, 414 .

Bland, Richard, member of the Virginia committee of correspondence, 403 .

Board of Trade, reports adversely on the church act of 1704,11 ; refuses to assist the colony during the Yemassee War, 12; interferes in the land controversy, 36 ; recommends repeal of election law of 1745,117 ; re ports adversely on the circuit court act of 1768,136 ; farors act of 1769,138 ; criticises Indian trade act, 216-217; recommends repeal of currency acts of 1721 and 1723,240 ; drafts commission and instructions of Governor Johnson, 268; recommends repeal of statute imposing differential duties, 286 ; recommends payment of salary of Chief Justice Wright, 299.

Bohun, Edmund, chief justice. 121.

Boone, Joseph, sent to England as agent of the dissenters, 10, 159; agent to deal with the proprietors, 160-161, 415; dispute 
over payment of salary of, 289291.

Boone, Thomas, appointed governor, 337 ; arrives in the prorince, 339 ; administration, $339-$ 347 ; dispute with the assembly over the Gadsden case, 340-347, see table of contents; sails for England, 347; assembly withholds salary of, $76,347-349$; mentioned, 79,170 .

Bosher, captain of rangers, 186.

Bouquet, Lieutenant-Colonel, commander of Royal American troops, 207.

Bowler, Metcalf, speaker of the Rhode Island House of Deputies, 404.

Braddock, David Cutler, captain of the Beaufort galley, 190-191.

Braddock, General, 133, 223.

Bralim. See De Brahm.

Braithwaite, John, member of the conncil, 315.

Brewton, Colonel Michael or Miles, powder receiver, 19-20, 411.

Brewton, Miles, son of above, member of assembly, 393.

Brewton, Robert, member of the assembly, 316; powder receiver, 411.

British troops in Charleston, dispute over furnishing of supplies, 358-359. See Independent Companies.

Broughton's battery erected, 198$199,205$.

Broughton, Thomas, speaker of the assembly, 4l4; argument to justify the control of the assembly over money bills, 294; member of the council, 271; lieutenant governor, 271; acting governor, 298; character, 298 ; administration, 298-306; death, 306 ; mentioned, 50,77 , 130.

Brown, captain of rangers, 186.

Brown, John, messenger of the assembly, 266.
Bruce, Captain, engineer, plans Charleston fortifications, 199201.

Bull, Stephen, assistant justice of Berkeley county (1683), 120.

Bull, Stephen, elected to the assembly (1745), 316.

Bull, Villiam, Indian commis. sioner, 215 ; member of the council, 271 ; president of the council and acting governor, 74 , 306 ; commissioned as lieutenant governor, 306; administration. 306-313; mentioned, 58, 61, 62, $77-78$.

Bull, William (the second), speaker of the assembly, 111,316 , 415; member of the council, 337 ; attends Indian conference at Albany, 222 note; lieutenantgovernor and acting governor, 337 ; character, 337 ; first administration, 337-339; second administration, $347-356$; third administration, 358,361 ; fourth administration, 366-379, fifth administration, 385-402, 402407 , see table of contents; mentioned, 52, 115, 128, 141, 157, $182,410-411$.

Burns, John, member of the council, 389 .

Caciques, 26 ; list of, 34-35.

Calhoun, John C.. 187 note.

Calhoun, Patrick, captain of rangers, 187.

Camden, judicial district created, 135, 141 ; mentioned, 397.

Campbell, Dougal, clerk of the common law courts, defeats attempt to use unstamped paper in the courts, 354-355; Lientenant-Governor Bull refuses to suspend him, 355; fined, 356 .

Campbell, Lord William, appointed governor, 385; arrives in the province, 402 ; administration, 402 ; instructions, date and number, 79 . 
Carey, Thomas, register of the court of vice-admiralty, 148 .

Carolina, ship of war, 189.

Carr, Dabney, nember of the Virginia committee of correspondence, 403.

Carter, John, agent of Virginia in England, complains of South Carolina's Indian legislation. 216.

Carteret, James, landgrave, 34 .

Carteret, Lord John, refuses to sell territorial interest in the Carolinas, 32 .

Carteret's bastion, location of, 197 .

Cary, Archibald, member of the Virginia committee of correspondence, 403.

Castle Pinckney, 201.

Catawba Indians, location, military strength of, 213; attend conference at Albany, 222 note; mentioned, 154 .

Cattell, William, Jr., member of the assembly, 393; mentioned. 313.

Cavalry, 173.

Certificates of indebtedness, issued by the assembly, 393.

Chancery, Court of, 119-120, 123.

Charles II., grants territory of Carolina, 3.

Charleston, founded, 6,196 ; location of in 1680,196 ; political and social center, 6,12 ; judicial center, $120,133,146-147$; fortifications of, $196-208$, see table of contents; judicial district created, 135, 141; galley, 188$189,191-192$.

Charlotte, Fort. See Forts.

Charter of 1629,3 ; of 1663,3 , provisions in regard to land grants, 25 ; of $1665,3,25$; charter appealed to in confirmation of the rights of representation, 345 .

Cheraws, judicial district created, 135, 141 ; mentioned, 397.
Cherokee Indians, location, military strength, 213; war with, $172,186,211,338$; mentioned, 210,216 .

Chester county, 184.

Chickasaw Indians, location of, 213.

Chicken, Colonel George, commissioner of Indian affairs, 215, 218.

Chief Justices, list of during proprietary period, 121 ; during the royal period, 4l3; tenure, 333; salary, 334. See Trott, Allein, Wright, Whitaker, Skinner, etc.

Chisolne, Major, commander of royal troops in Charleston, asks for supplies, 358 .

Choctaw Indians, location, 213.

Christ Church parish, inhabitants petition for increase of paper eurrency, 250; mentioned, 146 .

Church of England, law passed requiring members of assembly to conform to, 9; established by law, 10; laws opposed by the dissenters, 10-1l; disallowed in England, 11; church finally established 11; patronage, 21 .

Circuit courts, 133-141. See table of contents.

Classification of colonial governments, 1 .

Clerk of the assembly, dispute over election of, 111-115.

Coast defenses, 196-20s. See table of contents.

Coins, English little used, 229; Spanish, Mexican, and Peruvian brought in, 230 ; value fixed by statute, 230; amount of in the province, 231. See Proclamation money.

Cole and Beale galley, forfeited for violating acts of trade and navigation, 154 .

Colleton county, original location, 6 ; mentioned, $7,9,56,141,146$, 174. 
Colleton, James, governor, landgrave, 34.

Colleton, Sir John, member of the comncil, 315; elected to the as. sembly, 346 .

Colleton, Thomas, landgrave, 34; mentioned, 4.

Colleton's bastion, location of, 197 .

Colonial agent, $158-170$, see table of contents; list of agents, 415416.

Colonial Lake, mentioned, 201.

Columbia, mentioned, 208.

Commissaries General, list of, 4ll412.

Commissions and instructions, 78 79. See Instructions.

Comnittees of correspondence, in the Massachusetts towns, 403 note; Virginia Burgesses suggest inter-colonial committees, 403 ; South Carolina approves the plan and authorizes agency committee to act, 403-404; Rhode Island deputies appoint committee, 404; Connecticut, 404; Delaware, 404-405; mentioned, 159,162 note, $170,392$.

Commons house of assembly. See Assembly.

Common law, adopted by statute $(1712), 121$.

Common law courts, 120-133, see table of contents; judges $(1683), \quad 120, \quad(1721), \quad 123$, (1734), 129, (1765), 131, 353-354; chief justices, 121, 413.

Common pleas, Court of, 121-131. See table of contents.

Conant, Richard, assistant justice of Berkeley county (1683), 120 .

Concessions, Barbadoes (1663, $1665), 3$.

Congarees. See Forts.

Connecticut assembly appoints conmittee of correspondence, 404.

Conscience, Courts of, attempt to establisli, 142-143.
Conseiller's bastion, 205-206.

Constitution, colonial, resemblance to British constitution, 90-91, 289 ; in $1760,330-336$; change in character after 1760,$330 ;$ two conflicting theories of, $375-377$.

Continental Congresses, 405-406. Cooke, Sir John, opinion on the jurisdiction of admiralty conrts, 154.

Cooper, Dr. Thomas, opposes scheme of the land speculators, 43 ; imprisoned, deniel privileges of writ of habeas corpus, 43; released, 44; elected to the assembly, 44; appointed puisne baron of the court of exchequer, 156 ; mentioned, 105, 129 .

Coroner, 145.

Cosby, Governor of New York, 92. Coslett, Charles Natthews, appointed assistant justice, 139; urges removal of William Henry Drayton from the bench, 396.

Comei], executive, $85-88$; legislative, $90-95$; judicial, $118-120$. see table of contents; origin, $4-5,89$; separated from the assembly, 7,89 ; triple character of, 91-92, 94-95; confused ideas in regard to its position, 289 ; salary of officials, 95 ; powers of in $1760,332-333$; change in character after $1760,8 \pi, 234-$ 235, 331; opposes paper money schemes of the assembly, 234 seq.; right to sit as an upper house of the legislature questioned, 325-327, 387-393, 400401, see William Henry Drayton; list of members of $(1730)$, 271, (1743), 315, (1773), 389.

Council of Safety, supersedes the provincial goverument, 402 .

Counsel permitted in criminal cases, comparison with English custom, 12S.

Counterfeiting, dispute over bill to prevent, 388-393, 398. 
Counties, three origiual, 6.

Courts, 118-157, see table of contents: suggestion that courts pass upon the constitutionality of laws, 132.

Court houses built. 140-141.

Craven county, 6. $7.9,56,141$, 145.174.

Craven's bastion, location of 196197 ; mentioned, 200,205 .

Creek Indians, location, military strength of, 213: expedition against proposed, 260; uprising in Georgia, 187: invade the back country. 346: mentioned, 216.

Croft, Childermas, conmissioner of Indian affairs. 218.

Crokatt, James, colons agent in England, 165, 416; dispute be$t$ ween council and assembly over resignation of, $165-169,321-$ $322,332-333$; removed to London, 315; named as couneil or in Glen's commission, 315.

Crosskers, John, 18.

Cumberland, Richard, dramatist, provost marshal, 134, 412; sells his patent, 134.

Cushing. Thomas, speaker of the Massachusetts House of Representatives, $361,364,404$.

Dale, Thomas, assistant justice, 129.

Dalton, Joseph, register of lands, 28 note.

Daniel, Robert, assistant justice of Berkeley county (1683), 120.

Daniel, Pobert deputy governor, $161,183$.

Darbs, Michael, dissenter, refuses to take oath on the Eran. gelists, 99 .

Dart, Benjamin, member of the assembly, $349,362,369$; elected public treasurer, 377 note, 411 ; refused to advance moner on the order of the assembly, 379-380; assembly attempted to procure his arrest, 380 .

Dart, Joln, commissary general, 411.

Dartmoutl, Earl of, secretary of state for the colonies, 52, 182 , 396 and note.

De Brahm, William Gerald, engineer, superintends construction of fortifications, 203-204, $206-20$ \%

Debt, public, provision made for payment (1731), 272 .

De Gres, William, British attorner-general, report on the Wilkes fund controversy discussing control of assembly over the public treasury, $372-373$.

Delaware (Newcastle, Kent, and Sussex) assembly appoints committee of correspondence, 404405.

Differential duties. See Protection.

Digges, Dudley, member of the Firginia committee of correspondence, 403 .

Dissenters, Protestant, religious privileges of, 3 ; dispute with the church party, 9-11; members of assembly required to take an oath on the Evangelists, 99-100; attempt to remove disabilities of, 115-116.

Dorchester, Berkeley countr, fair and market established, 85; mentioned, 189.

Doyler, Daniel, assistant justice, i31, 354; deputy prorost marshal, 412 .

Drake. William, commissioner of Indian affairs, 218.

Drayton. Joln, member of the council, 389 ; joins his son in protesting against the actions of the council, $389,399-400$. See William Henry Drayton.

Draston. Thomas, member of the assembly, 316 .

Drayton, William Henry, elected 
to the assembly, 350; opposes the non-importation agreement, 369 ; appointed member of the conncil, 389 ; protests against postponement of the bill to prevent counterfeiting, 389 ; publication of protest leads to dis. pute involving the right of the council to sit as a branch of the legislature, 389-393; appointed assistant justice, 395 ; writes the Freeman pamphlet, 396 ; attempt to secure his removal from the bench, $396-397$; superseded by Judge Gregory, 397: delegate to the Provincial Congress (1775), 397; protests against further efforts of the council to block legislation, 398; placemen request his suspension from the council, 398399 ; defense, 399-401; suspension, 401.

Dry Savannah, mass meeting called at during riots of $172 \%$, 248.

Dry, William, assistant justice, 123; commissioner to stamp bills of credit, 240 ; commander of Goose Creek militia, 248; member and speaker of the assembly, $256,262,267,414$.

Dumning, William, speaker of the assembls, 415.

Dupont, Gideon, Jr., member of the assembly, 393 .

Dutarque, Lonis, 146.

Dynamics, financial, meaning of, 2.28-229; dynamics of the monetary sristem, 235, seq.: of the revenue srstem, $289-329$. See table of contents.

Echaw, 145.

Election laws, 95-100, 107-108, $115-117$, see table of contents; assembly complains of violation of law of $1721,249,365$; dispute over election law in the Gadsden case, $340-347$.
Elliot, Barnard, member of the council, 389 ; joins in defending William Henry Drayton against the placemen in the council, 399-400; delegate to the Provincial Congress, 397 .

Error, Court of, 118-119.

Estimates of public expenses, made by assembly alone after $1735,3 \dot{0} 2$.

Eveleigh, Samuel, assistant justice, 123; member of the assembly, 242, 316 .

Exchange, mediums of, 229 ; rate of between sterling and eurrency, 231, 233, 234, 274, 279; between sterling and proclamation moner, 230, 274, 279 .

Exchequer, court of, 51. 156-157.

Execntive, 73-88, see table of contents; weakness of, 334-336; list of executive offices, $8 \mathrm{~s}$; officials, 410-413.

Export duties, 285.

Fairchild, John, captain of rangers, 184-186.

Fairfield county, 184.

Fane, Francis, special counsel for colonial affairs. report on the quit rent act of $1744,68-69$.

Fees, 21, 77, 28s.

Fenwicke, John, assistant justice, 123 ; member of the council, 271 , 315; colonial agent, 416 .

Fenwicke, Thomas, speaker of the assembly, 414.

Ferguson, Thomas, member of the assembly, $343,369$.

Fewtrell, John, assistant justice, 139.

Financial history, 2:28-329. See table of contents.

Fitch, Tobias, commissioner of Indian affairs, 218.

Flamborough, ship of war, 189.

Fortifications, 196-208, see table of contents; fortification fund, 378 note. 
Forts, 208-212. See Frontier Defenses, table of contents.

Charlotte, erected, 212.

Congarees, erected, 20s; Indian trading post, 214.

Frederick, erected, 210 ; mentioned, 193, 194, 202, 211.

Johnson, erected, 197; independent troops stationed at, 194; damaged by storm of 1752,206 ; stamped paper stored in, 352; mentioned, 193, 200, 202, 208, 388.

King George, erected, 192, 209 ; destroyed by fire, 193, 209, 244; unsuccessful at. tempt to have it rebuilt, 210.

Loudon, erected, 211 ; destroyed. 211.

Lyttleton, erected, 211.

Moore, erected, 20s ; rebuilt, 210: independent troops stationed at, 194; Indian trading post, 214; mentioned, 141.

Pallachochola Old Town, erceted, 209; Indian trading post, 215 note.

Prince George, erected, 210211.

Francis, James, eaptain of rangers, $184-186$.

Frankland, Captain, of the war ship Rose, 191.

Frederick, Fort. See Forts.

Freeman, pamphlet written by William Hemry Drayton, 395396.

French, intrigue with the Indians, 184 ; erect a chain of forts from Canada to the Gulf of Mexico, 193; French and Indian War mentioned, 168, causes increase in issne of public orders, 275 , 277 , causes increase of taxation, 283; importance of overthrow of French power in America, $330-331$.
Frontier defenses, 208-212. See table of contents, also Forts.

Fundamental Constitutions, issued, 4; dispute over refusal of the people to subscribe to, 7 ; provisions relating to the land system, 26, 34; tend to foster a slave-holding aristocracy, 171 .

Fury, Peregrine, agent in England, $68,164-165,416$; defends assembly for withholding salary of the chief justice, 299 .

Gadsden, Christopher, disputed election case, $340-34 \bar{\gamma}$, see table of contents; opposes payment of Governor Boone's salary, 347; member of committee to consider circuit court act, 138; delegate to Stamp Act Congress, 350 ; represents the radical patriot party, 357; defends non-importation agreement, 369 ; chairman of committee on grievances, makes report condemning the removal of the assembly to Beaufort, 383 ; member of the committee of correspondence, 404 note; delegate to the Continental Congresses, 405406 ; mentioned, $170,351,362$, $385,393,407$.

Gadsden, Thomas, collector of the customs, 154.

Gage, General, letter to Earl of Halifax relating to independent troops, 195; letter to Governor Montagu, 35s.

Gaillard, Tacitus, nember of the assembly, 138.

Galleys, Charleston and Beaufort, 188-189, 191-192.

Gaols built, 140-1+1.

Garth, Charles, agent in England, $169-170,416$; purchases Cumberland's rights to the office of provost marshal, 134.

General duty act, 287, 30i-30s; dispute over renewal of, 395 . 
General sessions, Court of, 121131. See table of contents.

George I. death of, 256 .

George III, accession of, an epoch in the history of Great Britain and the colonies. 330 .

Georgetown, judicial district created, 135, 141; mentioned, 397.

Georgia, dispute with South Carolina over the subject of Indian trade, 218-219; assisted by South Carolina in the war with the Spanish, 189-190, 199, 277; detachment of independent troops sent to, 193.

Gibbes, Jolnn, cacique, 35.

Gibbes, Robert, sheriff, 120; chief justice, 121 .

Gibson, Roger, captain of rangers, 18.5.

Glen, James, appointed governor, 314; arrives in the province, $92-93,315$; administration, 314324 ; dispute with the couneil over his right to participate in their legislative sessions, 93-94; disputes with the assembly over appointment of fortification commissioners, 202-204, over Indian affairs, $221-222$, over issue of paper money, $275-276$, over a tax bill, $318-319$; refuses request of the assembly to disregard the legislative council, 387 ; letter to the Duke of Bedford discussing the colonial constitution (1748), 81-82, 107108 , 334-336; mentioned, 67 , 7ร. $79,111,117,125,165,166$, $168,210,323-324$.

Godin, Stephen, agent of the council in England, 164, 269, 415.

Gold coins. See Coins and Proclamation money.

Gordon, Thomas Knox, chief justice, 138, 399, 413: member of the council, 389 ; decision in the Powell case affirming the right of the council to sit as an upper honse of the legislature, 392-393; urges the removal of William Henry Drayton from the bench, 392-393, from the council. 399 .

Government, $\lceil 1-107$. See table of contents.

Governor, 73-85, see table of contents; excluded from the legislative council, 306 ; elaims right to be present, 323 ; weakness of, 334-336; list of governors of the royal period, 410-411.

Graeme, David, attorney at law, 104; attorney-general. 412.

Graeme, James, elected to assembly from Port Royal, 4i; chief justice, 413 ; judge of vice-admiralty, 414.

Graham, James, attorney at law, 154.

Grand council, 4-5. See Council. Grand jury, power to initiate legislation, 7 ; of Charleston. complains of rent roll bill of $1741,59-60$, finds fault with the militia, 182, condemns the Beaufort galler, 192.

Grant, Colonel James, leads expedition against the Cherokees, $186,338$.

Granville county, 56, 141, 146, 174, 183.

Granville, Lord, palatine, favors the church party, 10 .

Granville's bastion. location of, 196; mentioned, 205.

Gray, William, dispute over his election as captain of rangers, 185-186.

Great Britain, similarity of constitutional development in South Carolina and, 2.2s.

Green, Daniel, assistant justice, goes to England. 129; puisne baron of the conrt of exchequer, 1.56. 
Gregory, assistant justice, supersedes William Henry Drayton, 397.

Grey, William De. See De Grey. Grinnan, captain of rangers, 186.

Habcas Corpus, privileges of the writ refused to opponents of the land speculators, 43-45, to Landgrave Smith, 250.

Haldimand, Brigadier-General, in command of regular troops at St. Augustine, 359.

Halifax, vice-admiralty court opened at, 149 .

Halifax, Earl of, 195.

Half Moon (at Broad Street), 205.

Hall, Robert, deputy provost marshal, 412.

Hammerton, John, secretary of the province, $60-61,304,411$; receiver-general of the quit rents, $60-61,413$; member of the council, 271,315 ; sent as commissioner to Georgia, 219.

Hamor, Captain, of the ship Flamborough, 189.

Hampton county mentioned, 184.

Hardy, Charles, captain of His Majesty's ship the Rye, 189, 190.

Hargrave, Henry, deputy secretary of the province and elerk of the council, 266 .

Harrison, Benjamin, member of the Virginia committee of correspondence, 403.

Hart, Charles, secretary of the province, 411.

Hawk, sloop of war, 189.

Heath, Sir Robert, grant of Carolina to, 3 .

Henry, Patrick, member of the Virginia committee of correspondence, 403 .

Hepworth, Thomas, member of the committee of correspondence, 162 ; chief justice, 413 ; speaker of the assembly, 414; mentioned, 240 .
Herbert, John, commissioner of Indian affairs, $215,218$.

Hesse, Captain, engineer, sent to Charleston by Lord Loudon to superintend the construction of the fortifications, 207.

Heyward, Thomas, member of the assembly, 393 .

Hill, Charles, assistant justice, 123 ; chief justice, 413 ; mentioned, 162 .

Hillsborough, Earl of, secretary of state for the colonies, 115 , $128,140,152,362,370,372,380$, $381,382,388$.

Hodgson, Robert, eaptain of indepeudent troops, 194-195 note.

Hodgson, William, decision in case of, involving titles to land, 36 .

Hog Island Creek, 200, 201.

Horry, Elias, elected to the assembly, 316.

Horsey, Samuel, appointed governor, 314; death, 314.

Howard, Thomas, powder receiver, 17.

Howser, Henry, 240.

Hudson, Robert. See Hodgson.

Huguenots, 6, 9.

Hume, Robert, speaker of the assembly, 299, 415; mentioned, 154.

Hunt, eaptain of rangers, 186.

Hunter, George, surveyor-general of lands, 185, 413.

Hurricane of 1752, 204-206.

Hurst, Samuel, deputy provost marshal, 412 .

Import duties, 285, 287; amount of in $1725,1746,1747$, and 1748 , 287.

Independent companies, 192-195; stationed at Fort King George, $209,220,244$; mentioned, 184 .

Indian relations, 212-22 $\bar{i}$. See table of contents. See also Catawbas, Cherokees, Choctaws, Chickasaws, and Creeks. 
Infantry. See Militia.

Initiation of legislation, by the graud council, 5; by the grand juries, 7 ; by the assembly, 8, S9; assembly claims sole right, 20-21; council rarely initiates legislation, 332 .

Instructions to the governor, a part of the written constitution, $78-79$; validity of denied, 309 , 326 ; methods of interpretation, $375-376$; dispute over refusal of assembly to accept the additional instruction of April 14, $1770,373-386$, see Wilkes fund controversy.

Intercolonial wars, importance of in the development of colonial union, 331.

Irving, Thomas, receiver-general of the quit rents, 413 .

Izard, John, member of the assembly, 393.

Izard, Ralph, member of the council, 254, 271; member of the committee of correspondence, 162.

James' Island, 197.

Jefferson, Thomas, member of the Virginia committee of correspondence, 403.

Jenys, Paul, member and speaker of the assembly, 267, 415 .

John's Island, 146 note.

Johnson, Sir Augustus, judge of vice-admiralty, 149-150, 414 .

Johnson, Fort. See Forts.

Johnson, Colonel Guy, superintendent of Indian affairs, 224 .

Johnson, Sir Nathaniel, governor, favors church party, 9-11; dispute with assembly over the appointment of the public treasurer, 15-17; decision of crown officials affecting land grant to, 36 ; mentioned, 196.

Johnson, Robert, proprietary governor, deposed as a result of the revolution of $1719,13-14$; dis- pute with the assembly over the appointment of a powder receiver, 18-20 ; lieutenant-general of militia, 174; supersedes Nicholson as royal governor, 268 ; submits to Board of Trade plan for settling the currency question, 270; arrives in the province, $36,112,271$; administration, 36-48, 268-274, 295, 298 ; interested in land speculations, 41, 50; dispute with the assembly over the election of a clerk, 112-114; death, 298; mentioned, $76,77,79,129$.

Johnson's covered half-moon, location of, 197.

Johnson, Sir William, superintendent of Indian affairs for the northern district, 222-224, 227 ; death, 224 .

Jolnson, William, artisan, represents the radical patriot party, 357.

Johnston, governor of North Carolina, 67 .

Jones, John, popular leader in the riots of 1727,247 .

Jordan versus Law, test case involving the use of unstamped paper in the courts, 354 .

Judges, see Judiciary and Common Law Courts; list of ehief justices, 121, 413; list of viceadmiralty judges, 414 .

Judiciary, 118-157, see table of contents; dependent on the crown after 1735, 333-334.

Jury Act of 1731, 126-127, 157.

Justices of the peace, 14l-142.

Kettleby, Abel, landgrave, agent in England, 159-161, 415.

Kershaw, Joseph, member of the assembly, 138 .

King George Fort. See Forts.

Kinlock, James, member of the council, $271,315$.

Kirle, Sir Pichard, landgrave, 35. 
Lamb, Matthew, special counsel to the Board of Trade, 125, 143 note; reports adversely on the circuit court act of 1768,136 .

Lamboll, Thomas, assistant justice, 129.

Land bank established, 232-233.

Landgraves, 26; list of, 34-35.

Land system, 25-70. See table of contents.

Laurens, Henry, member of the assembly, 350,362 .

Lee, Richard Henry, nember of the Virginia committee of correspondence, 403.

Legal tenders, 230-275. See table of contents.

Legislative procedure, 255, 292$294,311-312$.

Legislature, 89-117. See table of contents.

Leigh, Sir Egerton, attorney-general, surveyor-general of lands, and judge of vice-admiralty, 413-414; member and president of the council, 389-390; argues against use of unstamped paper in the courts, 354; sued by Thomas Powell for false imprisonment, 392 ; accepts certificates of indebtedness issued by the assembly, 394 .

Leigh, Peter, chief justice, 413.

Lewis, Charles, dissenter, refuses to take oath on the Evangelists, 99.

Lewis, Maurice, elected to the assembly, 301; judge of vice-ad. miralty, 414.

Livingstone, William, goes to England to solicit the service of independent troops, 193.

Lloyd, Caleb, stamp distributor, retires to Fort Johnson for safety, 352; agrees not to attempt to lispose of stamps, 352 .

Lloyd, John, agent in England, $161-163,415$; speaker of the assembly, 267, 271, 414-415; mentioned, 242, 253.
Locke, Joln, landgrave, 34 .

Logan, George, public receiver, dispute over appointment, 1517.

Long Canes settlement, protected by rangers, $18 \%$.

Lords, House of, adopts resolutions condemning the action of Massacliusetts in opposing the Townshend Acts, 366 .

Lords Justices in Council, repeal the currency acts of 1721 and $1723,240$.

Loudon, Fort. See Forts.

Loudon, Lord, 207.

Loughton, IVilliam, deputy provost marshal, 412.

Lower courts, 141-147. See table of contents.

Lowndes, Charles, deputy provost marshal, 412.

Lowndes, Rawlins, member and speaker of the assembly, 342, $345,384-386,415$; member of committee on privileges and elections in the Gadsden case, 343 ; assistant justice, 131, 354; opinion in the printer Powell case denying the right of the council to sit as a branch of the legislature, 390-391; deputy provost marshal, 412; mentioned, $138,349,350,393,403$, 404.

Lowndes, Thomas, purchases Price baronies, 35; provost marshal, 412.

Lyford, captain of the Charleston galley, 191

Lynch, Thomas, dissenter, refuses to take oath on the Evangelists, 99.

Lynch, Thomas, member of the assembly, mentioned, 138, 348, 362,369 ; delegate to Stamp Act Congress, 350: delegate to First Continental Congress, 405 . Lyttleton, Fort. See Forts. 
Lyttleton, William Henry, governor arrives in the province, 325 ; administration, 325-327, transferred to the Jamaica government, 337; mentioned, 79, 182, $20 \%$.

MeCulloh, Henry, royal land commissioner, attempts to put an end to land frauds, $48-51$; attempts to secure a better collection of the quit rents, $57-69$; objections to the quit rent act of 1744, 66-67.

MeMahan, William, dissenter, refuses to take oath on the Evangelists, 99 .

MeNeal, captain of rangers, 186.

McPherson, eaptain of rangers, 185.

Manigault, Gabriel, public treasurer, 414 ; resigns, $61,312-313$; elected to the assembly, 316 .

Manigault, Peter, speaker of the assembly, 350, 361 , 364, 382, 415 ; resigns, 384 note; replies to Massachusetts circular letter of 1768,361 ; submits Massachusetts and Virginia letters to the assembly, 362 ; signs warrant for the arrest of the public treasurers, 380 ; mentioned, 343 , 349,354 .

Hanuaring versus Sacheverell, 45.

Marque and reprisal, letters of, $155-156$.

Marston, Rev. Edward, rector of St. Philip's, Charleston, opposes the extreme church party, 10 .

Maryland assembly, appoints committee of correspondence, 404.

Massachusetts House of Representatives, proposes intercolonial congress to protest against the Stamp Act, 350 ; sends circular letter criticising the Townshend Acts, 359-360, approved by Virginia House of Burgesses, 360361 , by the Sonth Carolina as. sembly, 362-363, ordered printed, 364; mentioned, 137 .

Mazyck, Isaac, elected to the assembly, 301, 316.

Merchants of Charleston, imprisoned for petitioning against the issue of paper moner, 236239.

Merchants of London trading with South Carolina, petition for settlement of currency question, $269-270$.

Michie, James, chief justice, 413; judge of vice-admiralty, 414; speaker of the assembly, 415.

Middleton, Arthur, president of the council and acting governor, administration, 241-268, 291295, see table of contents; controversy over payment of salary, 46,273 ; dispute with assembly over the election of a clerk. $111-$ 112 ; mentioned, $74,76,99,154$, 162,272 ; death, 306 .

Middleton, Edward, assistant justice of Berkeley county, 120.

Middleton, Henry, speaker of the assembly, 111,415 ; delegates to the First Continental Congress, 405.

Middleton, William, elected agent to England, refuses to serve, 169.

Militia, 171-182. See table of contents.

Minnick, Christian, captain of rangers, 185.

Monetary system, 229-278. See table of contents.

Money bills, 280-329, see table of contents; dispute over agent's salary, $165-169$.

Monke, John, cacique, 35.

Montague, Lord Charles Greville, arrives in Charleston, 348, 357 ; administration, $357-366$; 379-385; instructed to secure payment of Governor Boone's salary, 348; suspends Chief Justice Skinner from office, 
$35 \%$; spends summer (1768) in the northern colonies, 361 ; sails for England, 366; returus to the province, 379 ; refuses to approve Speaker Lowndes, 111, 385; again sails for England, 385 ; mentioned, 79, 137-138.

Montgomery, Colonel Archibald, leads expedition against the Cherokees, IS6, 338.

Hoore, Fort. See Forts.

Moore. James, governor, 9 ; chief justice. 121 .

IIoore, James (the second), revolutionary governor, 14; lieutenant-general of militia, 174; speaker of the assembly, 414; commissioner of Indian affair's, $217-218$; death, 218 .

Morton, Joseph, landgrave, 34; governor, 29, 120: judge of the court of vice-admiralty, 148 .

Motte, Jacob, appointed public treasurer, 312-313; ordered by the assembly to advance money to the Wilkes fund, 369 ; dispute over attempt to reimburse him and his estate, $371-386$; death, 374 .

Notte, Jacob, Junior, powder receiver, 411 .

Moultrie. James, attorner-general, 412.

Monltrie, William, dispute with Governor Boone, 3 46 ; mentioned, 349.

Murray, John, assistant justice, 139 ; death, 394.

Nairne, Thomas, Indian agent, 214.

Naval stores, mentioned, 159, 163.

Navigation dets. See Trade and Navigation Acts.

Navy, 15i-192.

Nicholas, Robert Carter, nember of the Virginia committee of correspondence, 403.

Nicholson, Francis, governor, arrives in the province, 123, 234; character and training, 234 ; administration, 234-241, 289-291; dispute with commons over duration of general assembly, 10s-110; brings over company of independent troops, 192 ; returns to England, 241; mentioned, $14,46,75,79,98-99$. $125,209$.

Ninetr-Six, mentioned, 184; judicial district created, 135,141 .

Negroes, special court for the trial of, 143-145. See Slaves.

Nelion, Pascal, captain of independent troops, 194.

Newberry county, 184.

Neweastle, Duke of, $43,69,70$. 73. $75,156,164$.

New England, influence of on the other colonies, I10, 345, 351, 361-362; takes lead in the Stamp Act controversy, 349$350 ;$ comparison of colonial constitutions in New England and the south, $376-37 \bar{i}$.

New Windsor. See Fort Moore.

Non-importation agreement formed, 368-369.

North Carolina, members of assembly paid in, 115; South Carolina attempts to make it a dependency, 163.

Norther, Attorney-General, opinion on the jurisdiction of admiralty courts, 154.

Northumberland, Earl of, appointed rice-admiral of America, 149.

Officials, list of in appendix, 410416; erown officials nsually sent from England, 235, 331.

Oglethorpe, General James, 190 , 219.

Oliphant, Doctor David, member of assembly, 343 .

Orangeburg. judicial district created, 135, 141.

Ordinary, Court of, 119. 
0'Sullivan, Florence, surveyorgeneral, 28 note.

Owen, William, popular leader, 5 .

Pallachocola Old Town. See Forts.

Parishes, established (1704-1706), 10-11; made basis of representation in the assembly, 11, 12, 96 ; list of $(1721), 100$; number $(1770), 100$.

Parris, Alexander, assistant justice, 123; public treasurer, 411; mentioned, 15-16.

Parsons, James, member of the assembly, mentioned, 349, 351, $362,369,385$; presents popular petition urging the use of unstamped paper, 354; member of the committee of correspondence, 404 note.

Patrol system, 179-181.

Pearson, John, sent to survey North Carolina boundary, 185 ; captain of rangers, 186 .

Pendleton, Edmund, member of the Virginia committee of correspondence, 403.

Pension system, 176 .

Peronneau, Henry, elected public treasurer, $37 i$ note; refuses to advance money on the order of the assembly, 379-380.

Phillips, Richard, eaptain in command of battalion from the Royal American Regiment, 195.

Pilkington et al. versus Snow Trow Aletta and Cargo, 156.

Pinckney, Charles, son of Thomas, member of the assembly and speaker, $301,311,415$; reports resolutions defending the control of the assembly over money bills, 296-297; sent as commis. sioner to Georgia (1736), 219; momber of the council, favors the removal of the civil disabilities of dissenters, 116 ; at- torney-general, 4l2, chiefjustice, 413; mentioned, 154, 166.

Pincknes, Charles, son of William, member of the assembly, mentioned, 343, 349, 350, 35̄1, 354, $362,385,393$; member of the committee of correspondence, 404 note.

Pinckney, Charles Cotesworth, nember of assembly, 385; member of the committee of correspondence, 404 note.

Pinckney, Roger, deputy provost marslial, 134, 412; sheriff of Charleston district, 390 .

Pinckney, William, master in chancery, deputy secretary of the province, 95 ; commissioner of Indian affairs, 218; elected to the assembly, 316 ; commissary general, 412.

Piracy, 150-152.

Placemen, fill best offices in the province, 139.

Plan of book, 2 .

Planters, grievances of. 258-259.

Police of Charleston. See Watch.

Pollinger, R., marshal in the court of vice-admiralty, 148 .

Population, character of, 6 ; increase of, 6 .

Porter, Captain Matthew, powder receiver, 18.

Port Royal, settlement at $(1670)$, 4 ; mentioned, 163, 18\%, 19:193, 208-209.

Powder receiver, dispute over appointment of, 17-20; list of powder receivers, 411 .

Powell, George Gabriel, member of the assembly, 138, 385; opinion in the printer Powell ease, 391.

Powell, Thomas, editor of the Gazette, publishes the Drarton protest, 389-390; arrested, ivg: trial involves the right the council to sit as a branch of the legislature, 390-393. 
Poxell versus Leigh, 392-393.

Pownall, Thomas, appointed gorernor, but does not come to the province, 337 .

Price, John, landgrave, 35.

Prince George. See Forts.

Pringle, Robert, assistant justice, $131,353$.

Privateers, 155-156.

Privileges, of the assembly. 104$105,236-239,303-305$; of the council, 91.

Prize cases, 156.

Proclamation money, 239 and note. See Statutes, Proclamation.

Produce made legal tender, 229230.

Proprietars period (1670-1719), 1-33. See table of contents.

Protection, to ship-building industry, 285-286; law repealed on complaint of British merchants and ship-builders, 286; system of bounties, 287 .

Protestant, dissenters, see dissenters; settlers given public assistance, 272 .

Provineial navy, 18j-192; dispute over re-organization of, 319 .

Provost marshal, opposes attempts to establish courts in the upper country, 134; sells interests, 135 ; list of provost marshals, 412.

Rublic orders, 272, 275-277. See table of contents.

Public Records, extra volumes of, 256 note.

Public Treasurer. See Treasurer.

Quia Emptores, statute of inoperative, 3, 25.

Quit rents, 28-31, 54-70, see table of contents; quit rent act of $1731,37-48,272$; mentioned, 7, 269 .

Quo Warranto, writ of, $7 \vec{i}$.

Ramon, Don Pedro, $15 \tilde{4}$.
Randolph, Edward, 148, 341.

Randolph, Colonel Peter, surveyorgeneral of customs, suggests method of ending the Stamp Act embargo, 352-353.

Randolph, Peyton, speaker of the Virginia House of Burgesses. 364; member of the committee of correspondence, 403; mentioned, $367,404$.

Rangers, 182-187.

Rattray, John, judge of vice-admiralty, 414.

Rebellion, growth of the spirit of, 386-402. See table of contents.

Receivers-General of the quit rents, list of, 413 .

Receiver, Public. See Treasurer. Regulators, organized to preserve order in the upper country, 133, 137.

Reid, James, powder receiver, 411. Religious disputes, 9-11.

Revenues, $279-329$. See table of contents.

Revolution of 1719, 13-14.

Rhett, William, surveyor and comptroller of the customs, complaints against, 163; men. tioned, 12.

Rhett, William (the second), member committee on the currency, 242,253 ; reports, 257 .

Rhode Island, House of Deputies appoints committee of correspondence, 404.

Rice bills, 234, 236.

Riots of $1727,246-249$.

Rose, ship of war, 191.

Rothmaller, Job, 47.

Rowe, Major Thomas, eacique, 35.

Royal Ameriean Regiment, 195.

Royal troops. See Independent companies.

Rusco versus French, 39.

Russel, captain of rangers, 186.

Rutledge. Andrew, nember and speaker of the assembly, 301, 316,415 . 
Rutledge, Edward, represents the plaintitf in Poxell versus Leigh, 392 ; delegate to the Continental Congresses, 405-406.

Rutledge, Joln, brother of Edward, chairman of committee on privileges and elections, 343 ; reports on the Gadsden case, 343 ; delegate to the Stamp Act Congress, 350-351; elected to the last general assembly of the colonial period, 385; member of the committee of correspondence, 404 note; delegate to the Continental Congresses, 405-406; attorney-general, 413; mentioned, 138, 354, 362, 369.

Ryder, attorney-general of Great Britain, 33.

Rye, ship of war, 189 .

St. Andrew's parish, 100 .

st. Antonio, ship forfeited for violating acts of trade and navigation, 154 .

St. Augustine, expedition against (1702), 9, 174, Spanish at encourage slaves to run away, 307 ; mentioned, 187, 189, 190.

St. Bartholomew's parish, inhabitants petition for increase of paper currency, 250; mentioned, 100.

St. Dennis's parish, 100, 146, 250.

St. George's parish, 100, 145.

St. Helena's parish, 100 .

St. James's Goose Creek, 100, 145; militia company takes lead in the riots of 1727,248 .

St. James's Santee, 100, 145, 250.

St. John, James, surveyor-general of lands, 38,413 ; arrives in the province, 38 ; opposes the schemes of the land speculators $38-47$; mentioned, 69.

St. John's parish, 100, 145, 250 .

St. Paul's parish, 100, 250.

St. Philip's parish, Charleston, 10 , 100,175 .

St. Simon's island, 190.
St. Thonlas's parish, 100, I4t, 250 . Salaries, regulated by statute, 80 ; salary of the chiet executive, i4-is; dispuies orer the payment of President Middleton"s salars, 273, 295; Governor Boone's, 347-349: Chief Justice Wright's, 45-46, 295-302; salaries of the clerks of the assembly and the council, dispute over, 290 ; salary of colonial agent, $159, \quad 160-164$, dispute over payment, 160-161, 166$168,289$.

Sarage, Edward, assistant justice, 139 ; judge of vice-admiralty, 414.

Savannah, headquarters for Indian trade, 219.

Savanna Town (Fort Moore), 208.

Saxby, George, receiver general of the quit rents, $61,6 \%, 413$; elected to the assembly, 316 ; stamp distributor, retires to Fort Johnson for safety, 352.

Sacle, William, governor, 4, 5, 26, 28 .

Scire facias, writ of, 11 ; not issued by the court of chancery in South Carolina, 120.

Scotch-Irish, I33, 171 .

Scout boats, 187-188.

Scouts. See Rangers.

Scovilites, opponents of the Regulators, 137.

Scrivener, William, popular leader, 5.

Seabrooke, Captain, member of the assembly. 109.

Seckendorf, Count, 203.

Secretaries of the province, list of, 411.

Sharpe, John, 165.

Sheed, George, commissary general, 412.

Shelburne, Earl of, 170.

Shelton, Richard, secretary to the lords proprietors, 299.

Ships of war, roval, in the colony (1742), 189-190. 
Simmond, Captain, nember of the assembly, 109.

Simons, Benjamin, commissary general, 412.

Simpson, James, clerk of the council, 392; attorney-general, 4l3; surveyor-general of lands, 413; judge of vice-admiralty, 414 .

Simpson, Willian, chief justice, 413.

Silver. See Coins and Proclama. tion money.

Sinking fund act (1724), 241; suspended for seven years, 270 .

Skene, Alexander, member of the council, $247,249,271,315$.

Skinner, Charles, chief justice, refuses to use unstamped paper in the courts, 353; overruled by assistant justices, 354 ; dissenting opinion, 354 ; forced to celebrate repeal of the Stamp Act, 355 ; removed from office, 356357; mentioned, 131, 170, 413.

Skottowe, Thomas, member of the council, 389 ; secretary of the province, 411.

Slaves, special courts for trial of, 143-145; enticed by Spanish to escape to St. Augustine, 171; employed as troops, 175-178; outnumber the whites, 179; basis of taxation, 282 ; tax on slave trade, 285 note, 287 . See Patrol system.

Smith, Benjamin, assistant justice, 131,354 ; speaker of the assembly, 338-339, 342, 4l5; men. tioned, 345.

Smith, Captain George, public treasurer, 17.

Smith George (the second), member of the assembly, 253 .

Snith, James, judge of vice-admiralty, 414.

Smith, John, cacique, 35.

Smith, Captain Richard, member of the assembly, 104.

Suith, Landgrave Thomas, governor, 8.
Smith, Landgrave Thomas, son of preceding, member of the council, takes popular side in the riots of 1727,248 ; imprisoned, refused privileges of the writ of habeas corpus, 248, 250, 261262.

Smith, Thomas, son of preceding, member of assembly, leads the popular party in the riots of 1727,247 ; re-elected to the assembly, 267 .

Smith, William, powder receiver, 18 note.

Somerville, Tweedie, 156.

Spanish at St. Augustine, encourage slaves to run away, 171 ; wars with, 171-172, 188191, 198-199; evacuate Florida, importance of, 331 .

Speaker of the assembly, 110-111; list of speakers, 414-415.

Spry, William, appointed admiralty judge for America, 149.

Stamp Act controversy, 349-357. See table of contents.

State oaths for members of assembly, administered by the governor, 98 ; disputes over, $98-$ $100,340-347$; final settlement, 349 .

Statics, financial, meaning of 228229 ; statics of the monetary system, $229 \mathrm{seq}$.; of the revenue system, 279-288.

Statutes (of England and Great Britain), one hundred and sixty-seven adopted into the province (1712), 121-122.

Quia Emptores, suspended, 3, $25,28$.

Acts against piracy Henry VIII, chap. 15 and 11 and 12 William III, chap. 7 , mentioned, 150, 152.

Act of 7 and 8 William III, chap. 22, for punishing violations of the navigation acts, 153 . 
Trade and Navigation Acts, 148, 153-154.

Proclamation statute (1707), $230,278-279$; attempts of the assembly to violate, 253-254, 257-259, 321.

Act of 1729 puchasing the territorial interests of the proprietors, 14, 32, 268.

Act of 1751 forbidding New England colonies to issue bills of eredit, 275 ; extended to other colonies (1764), 275.

Stamp Act $(1765), 76,349-$ 357. See table of contents.

Townshend Acts, 358.

Act 35 Henry VIII, chap. 2 concerning treason, 366 .

Stobo, James, dissenter, refuses to take oath on the Evangelists, 99.

Stono insurrection, 50, 106 note, $144,172,181,187,307$.

Storm of 1752, 204-206.

Strange, solicitor-general of Great Britain, 33.

Stuart, John, member of the council, 389 ; superintendent of Indian affairs, 224, 227, 389.

Success, ship of war, 189.

Superintendent of Indian affairs, $222-22 \%$, see table of contents; list of, 416 .

Surveyors-General of lands, list of, 413.

Talbot, solicitor-general of Great Britain, 36.

Taxation, 279-329. See table of contents.

Tax certificates, 277-278; issued on sole responsibility of the assembly, 278, 393-394.

Taylor, Captain Peter, sent as commissioner to Georgia, 219; commissary general, 411 .

Tendencies in colonial history, 1.

Thompson, Major William, commander of rangers, 186.
Tipper's bastion, 205.

Tonnage duties paid in powder, 288.

Townshend, Charles, 70.

Trade and Navigation Acts, 148, 153-154.

Treason, parliament resolves that colonial cases shall be tried in England, 366-367.

Treasurer, Public, disputes over election of, $15-17,312-313$; list of treasurers, 411 .

Trewin, William, opposes land speculators, $43-44$; is persecuted, 47 ; elected to the assembly, 301 ; judge of vice-admiralty, 414 .

Trott, Nicholas, chief justice, advises proprietor's to refuse concessions to the people, 12; holds monopoly of judicial positions, 13; on commission to try pirates, 151 ; attorney for Landgrave Smith, 252; mentioned, $121-122,125,160,289$.

Troops, regular in Charleston, dispute over furnishing of supplies, 358-359. See Independent companies and Royal American Regiment.

Tryon, Rowland, colonial agent, 415 .

Turner, Matthew, 152.

Tuscarora bills, issued to meet the expenses of the Tuscarora War, 232.

Tynte, Edward, governor, 31.

Union, growth of the sentiment of colonial, 366, 386, 402-407. See table of contents.

Union county, 184.

Unity of colonial history, 1.

Upper country, need of courts in, 133-134, 365; organization of the Regulators, 133, 137; circuit courts established, 133-141.

Vanderdussen, Alexander, goes to England to solicit the service of independent troops, 194; ap. 
pointed lieutenant-colonel of troops and member of the council, 194.

Vanderhorst creek, 198, 199.

Veto, rarely used by the governor in the case of money bills, 321 .

Virginia, members of assembly receive pay in, 115 ; independent troops removed to, 195; dispute with South Carolina in regard to the Indian trade, 216-217; House of Burgesses passes resolutions protesting against the treasons act, 367, approved by the South Carolina assembly, $367-368$; Burgesses approve Massachusetts circular letter of 1768 and send out similar one, 360-361, approved by South Carolina assembly and ordered printed, 362-364; Burgesses adopt resolutions originating intercolonial committees of correspondence, 403 .

Waities, William, popular leader in the riots of $17 \cdot 2 \pi, 24 \pi$; reelected to the assembly, 267 .

Wando precinct, 146 .

Waring, Thomas, member of the council, 271,315 .

Wassamsaw in Berkeley county, $145,146$.

Watch, Charleston, 178-179.

Watts, captain of rangers, 186.

West Indies, coins brought from in trade, $230-231$.

West, Joseph, governor, 172, 196, 213 ; landgrave, 35.

West, Richard, counsel to the Board of Trade, opinion denying right of the governor to sit in the legislative council, 92 ; report on Indian trade act, 216217.

Whitaker, Benjanin, member and speaker of the assembly, 111, $265,301,415$; attorney-general, 412; chief justice. 413; judge of vice-admiralty, 414 ; reports to the Board of Trade on the quit rent act (of 1731), 39-40, (of 1744), 65-66; letter to Henry McCulloh discussing the jurisdiction of the law courts, 131132, suggests that the courts pass upon the constitutionality of laws, 132; mentioned, 47, 69, $154,236$.

White Point Garden, watch house erected in, 198.

Wilkes fund controversy, dispute over contribution to the fund to pay the debts of Jolnn Wilkes, $170,369-386$. See table of contents.

Wilkinson, Captain, cacique, 35.

Williamson, William, deputy provost marshal, 412.

Willtown, 145.

Windmill Point, 197.

Winyaw, Indian trading post, 214.

Wood, Adam, deputy provost marshal, 412.

Workhouse, location of, 200-201.

Wragg, Joseph, nember of the council, 271, 315.

Wragg, Samuel, agent in England, 163,415 .

Wragg, William, member of the assembly, 343 ; opposes nonimportation agreement, 369 .

Wraxall, Peter, secretary for Indian affairs, proposes plan for management of Indians, 223224.

IVright, James, son of Robert Wright, attorney-general, 412; agent in England, 169, 416; lieutenant-governor and governor of Georgia, 169 and note.

Wright, Robert, member of the council, 271,315; chief baron of the court of exchequer, 156 ; chief justice, 43, 413; opposes the land speculators and defends the Habeas Corpus Act, 43-45; dispute over pasment of salary, 45-46, 295-302; mentioned, 77 , 129, 130 ; death, 315 . 
Wright, Thomas, son of Robert Wright, member of the assembly, 104; probable author of article in the Gazette questioning the right of the council to sit as an upper house, $325-32 \pi$. 388 ; mentioned, 351.

Yeamans, Sir John, 4; landgrave, 34.

Yemassee Indians, war with (1715), 12, 172, 208; bills of credit issued to meet expenses of war, 233 .

Jerworth, John, shipwright, 188. Yonge, Francis, agent in England, $13,161-163,299,415,416$; member of the council, 271 ; defends privileges of the assembly, 45; chief justice, 123, 413.

York county, 213.

Yorke, attorney-general for the crown, 36. 



\title{
The Foundations of American Foreign Policy
}

\author{
WITH A WORKING BIBLIOGRAPHY
}

\section{By ALBERT BUSHNELL HART}

Professor of History, Harvard University; Author of " American

History told by Contemporaries," etc.

Cloth. $12 \mathrm{mo}$. \$1.50, net

"A very good introduction to the whole subject. There are seven chapters comprising as many diplomatic phases: The United States as a World Power, The Experience of the United States in Foreign Military Expeditions, Boundary Controversies, A Century of Cuban Diplomacy, Colonies, What the Founders of the Union thought concerning Territorial Problems, and the Monroe Doctrine. To these is added a working bibliography of American diplomacy, sure to be helpful to those who wish to pursue the subject systematically."-St. Louis Post-Dispatch.

"This book is of great value to students and statesmen, editors and politicians, being a coniplete résumé of the diplomacy of this government from the time it threw off the yoke and took its place as an independent nation. Professor Hart is a very clear, concise, and interesting writer, and he not only recapitulates the facts of history, but arranges and compares them in such a way that his readers can easily follow the trend of American ideas."-Nebraska State Journal.

"Lucidly written, and the conclusions reached are indisputable. . . . The book may be commended to 'anti-imperialists' for their instruction. Yet it is not controversial in tone or partisan in its arguments; it contains simply the results of profound historical knowledge. A bibllography adds greatly to its value."-Providence Journal.

\section{American Diplomatic Questions}

\author{
By JOHN B. HENDERSON, Jr.
}

\author{
Cloth. 8vo. 3.50, net
}

"Of rast practical service to every American who gives to the great international questions of his country the attention they deserve, nor, indeed, does its usefulness stop there. It will be found as servicesble in Europe, though there, naturally enough, its use will be restricted to diplomatic circles, members of parliaments, editorial writers, and a limited number of students of intornational affairs, whereas with us it is a book for all the people, for all voters, who may be called upon to take into consideration most of the large issues here involved, which are of the present and the future, as well as of the past. The book deals with the fur seals and the Behring Sea Award; the inter-oceanic canal problem; the Samoan question, now settled to our entire gatisfaction, and, therefore, at present at least, strictly historic ; the Monroe Doctrine, with special reference to the Venezuelan boundary dispute ; and the northeast coast fisheries--a problem that is gradually adjusting itself without diplomatic interference."-The Mait and Express (New York).

\section{ThE Macmillan COMPany}

\author{
66 Fifth Avenue, New York
}




\section{The History of South Carolina under the Pro= prietary Government, $1670=1719$}

\section{The History of South Carolina under the Royal Government, $1719=1776$}

\section{The History of South Carolina in the Revo= lution, 1775-1780}

\section{The History of South Carolina in the Revo= lution, $1780=1783$}

8vo. Cloth. Gilt top. Each \$3.50, net

By EDward McCrady, a Member of the Bar of Charleston, S. C., and President of the Historica? Society of South Carolina.

"Unquestionably a valuable contribution to American historical literature. It covers a tield that no one else has hitherto attempted to adequately treat of. It evidences a vast amount of research into musty archives and an instinct that guided the author to a discriminating selection of material. . . The future must surely be indebted to Mr. MeCrady in no mean degree."-St. Louis Globe-Democrat.

\section{Reconstruction in Mississippi}

By JAMEs W. GARNer, Ph.M., Member of the Mississippi Historical Society. Cloth. Svo. \$3.00, net.

"The latest and one of the most valuable examples of pacific literature which is eradicating the bitterness from our national history. It has taken over 400 pages to enable Mr. Garner to tell the story of that time of distrust and calamity, and even with so generous an allowance of space he bas not been able to permit bimself much comment, but has packed every page with facts, taking the pains in each instance to give his authorities for statements made. . . The story that follows is one of arrogance upon both sides, of frailty and passion, indignation, courage, conscience, fanaticism, nobility and contemptibility. Mr. Garner has made the dry records of the legislature and newspapers tell their dramatic story, and it will be impossible for any American to read it without sympathy. . . . It is a valuable chapter of American history, and should have no lack of readers."-Chicago Tribune.

\section{Maryland as a Proprietary Province}

By Newton D, Mereness, Sometime University Fellow in History in Columbia Uni versity. Cloth. Svo. \$3.00, net.

"We cannot speak too highly of the way in which this work has been done. Dr. Mereness has studied every point in the light of the original contemporary documents, printed and in manuscript, not only those in the archives of the State, but those in private collections; and references to the authorities contirm every statement. The labor undergone has been great; but the result is a work planned and earried out in the truest historical spirit, and invaluable to the student of American history and institutional development'.'-The Nation.

\section{THE Macmillan COMPANY}




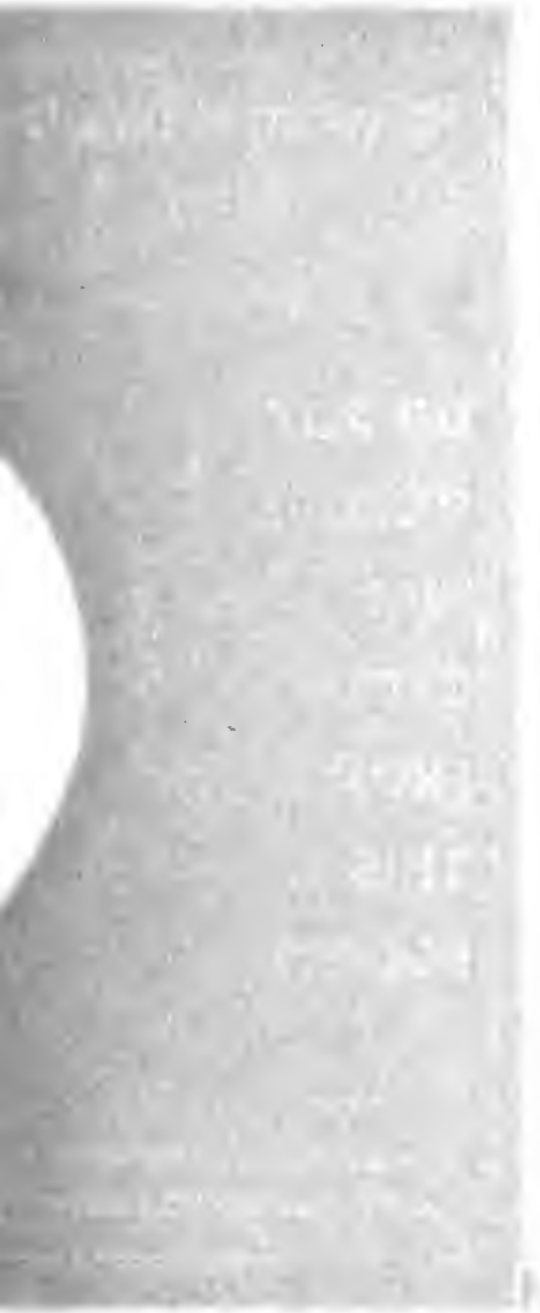




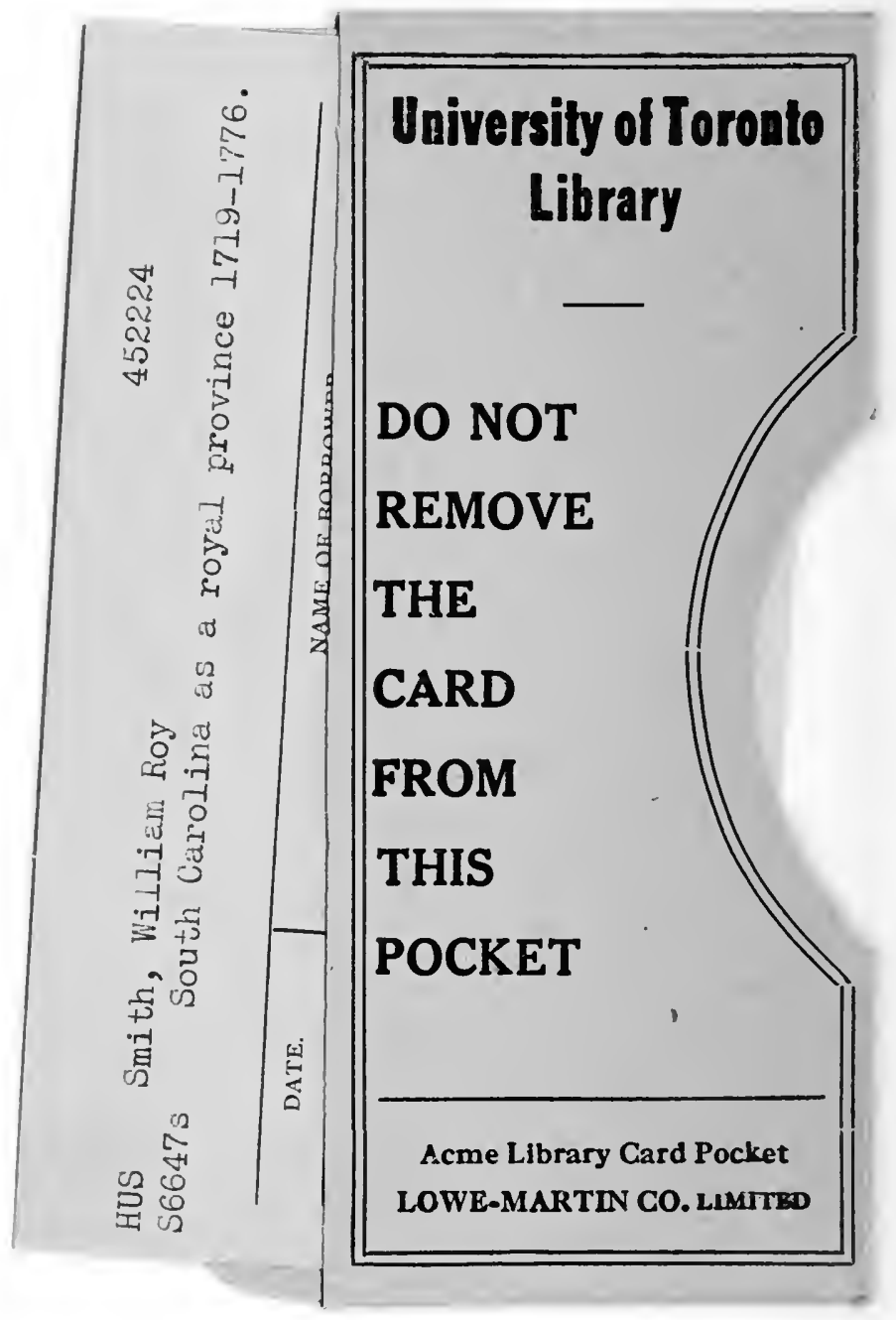


